\title{
EU BIBLIOGRAPHY
}

\author{
Compiled by:
}

Aleksandra Čar, European Documentation Centre, Library of the Faculty of Law, University of Zagreb*

Below you will find a list of bibliographic references to selected articles in the field of European law and policy.

This issue covers items from a wide range of academic and specialised periodicals published from November 2016 to November 2017. References are presented in 19 subject headings covering all activities of the European Union.

\section{EU - Croatia}

1 ÇARKOĞLU, Ali; Glüpker-Kesebir, Gitta. Comparing Public Attitudes on EU Membership in Candidate Countries: The Cases of Croatia, Macedonia and Turkey from 2004 to 2011. Southeast European and Black Sea Studies. 16 (2016) No. 2: 255.

2 ČIČIN-ŠAIN, Nevia. Reflections on the Structure of Croatian Measures for Limiting the Deductibility of Financial Expenses: Efficiency vs Compatibility. Croatian Yearbook of European Law and Policy. 12 (2016): 146.

3 HIEßL, Christina; Laleta, Sandra. Implementation Problems of the Collective Redundancies Directive and their Consequences : The Croatian example. Europäische Zeitschrift für Arbeitsrecht = European Journal of Labour Law. 10 (2017) No. 3:441.

$4 \mathrm{HOH}$, Anna-Lena. 'When Counting Counts' - Europeanisation of Census-Taking in Croatia, Bosnia and Herzegovina and the Former Yugoslav Republic of Macedonia. Journal of Contemporary European Research. 13 (2017) No. 1: 17 pp.

5 LISZT, Marijana; Butorac Malnar, Vlatka. SGEI in Croatia: The Legal Framework for Economic Necessity. European State Aid Law Quarterly. 15 (2016) No. 4: 622.

6 MENĐUŠIĆ ŠKUGOR, Ema. EU Procurement Reform: The Case of Croatia. Public Procurement Law Review. (2017) No. 2: 115.

7 MILAČIĆ, Filip. A Painful Break or Agony Without End? The Stateness Problem and its Influence on Democratization in Croatia and Serbia. Southeast European and Black Sea Studies. 17 (2017) No. 3: 369.

8 TOPLAK, Jurij; Gardasevic, Djordje. Concepts of National and Constitutional Identity in Croatian Constitutional Law. Review of Central and East European Law. 42 (2017) No. 4: 263.

02 EU: General and institutional developments

(Process and theory of European integration / Current issues and challenges / Policymaking process / Openness and transparency / European Council / Council of the EU / European Commission / European Parliament / Other EU organisations and agencies)

\footnotetext{
I wish to thank Tena Maček, student at the Faculty of Law in Zagreb, for her valuable assistance in the compilation of this bibliography.
} 
9 ALEXANDROVA, Petya. Institutional Issue Proclivity in the EU: The European Council vs the Commission. Journal of European Public Policy. 24 (2017) No. 5: 755.

10 ANDREADAKIS, Stelios; Morrison, Scott. Whistleblowers Under the Spotlight. European Journal of Comparative Law and Governance. 3 (2016) No. 4: 353 pp.

11 ARES, Macarena; Ceka, Besir; Kriesi, Hanspeter. Diffuse Support for the European Union: Spillover Effects of the Politicization of the European Integration Process at the Domestic Level. Journal of European Public Policy. 24 (2017) No. 8: 1091.

12 AUEL, Katrin; Neuhold, Christine. Multi-Arena Players in the Making? Conceptualizing the Role of National Parliaments since the Lisbon Treaty. Journal of European Public Policy. 24 (2017) No. 10: 1547.

13 AUER, Andreas. The People Have Spoken: Abide? A Critical View of the EU's Dramatic Referendum (In)Experience. European Constitutional Law Review. 12 (2016) No. 3: 397.

14 BAIRD, Theodore. Non-State Actors and the New Intergovernmentalism. Journal of Common Market Studies. 55 (2017) No. 6: 1192.

15 BALLER, Inger. Specialists, Party Members, or National Representatives: Patterns in co-Sponsorship of Amendments in the European Parliament. European Union Politics. 18 (2017) No. 3: 469.

16 BAUDENBACHER, Carl. After Brexit: Is the EEA an Option for the United Kingdom? European Law Reporter. (2016) No. 4: 134.

17 BELLAMY, Richard; Kröger, Sandra. A Democratic Justification of Differentiated Integration in a Heterogeneous EU. Journal of European Integration. 39 (2017) No. 5: 625 .

18 BENZ, Arthur. Patterns of Multilevel Parliamentary Relations. Varieties and Dynamics in the EU and Other Federations. Journal of European Public Policy. 24 (2017) No. 4: 499.

19 BERKHOUT, Joost; Hanegraaff, Marcel; Braun, Caelesta. Is the EU Different? Comparing the Diversity of National and EU-Level Systems of Interest Organisations. West European Politics. 40 (2017) No. 5: 1109.

20 BEVIR, Mark; Phillips, Ryan. EU Democracy and the Treaty of Lisbon. Comparative European Politics. 15 (2017) No. 5: 705.

21 BEVIR, Mark; Phillips, Ryan. Genealogies of European Governance. Comparative European Politics. 15 (2017) No. 5: 685.

22 BILČÍK, Vladimír. The Slovak EU Council Presidency: In Defence of Post-Brexit EU. Journal of Common Market Studies. 55 (2017) No. S1: 64.

23 BIRCH, Sarah; Van Ham, Carolien. Getting Away with Foul Play? The Importance of Formal and Informal Oversight Institutions for Electoral Integrity. European Journal of Political Research. 56 (2017) No. 3: 487.

24 BLATTER, Joachim; Schmid, Samuel D.; Blättler, Andrea C. Democratic Deficits in Europe: The Overlooked Exclusiveness of Nation-States and the Positive Role of the European Union. Journal of Common Market Studies. 55 (2017) No. 3: 449.

25 Blauberger, Michael; Schmidt, Susanne K. The European Court of Justice and its Political Impact. West European Politics. 40 (2017) No. 4: 907.

26 BOEGER, Nina; Corkin, Joseph. Institutional Path-Dependencies in Europe's Networked Modes of Governance. Journal of Common Market Studies. 55 (2017) No. 5: 974.

27 BOLLEYER, Nicole. Executive-Legislative Relations and Inter-Parliamentary Cooperation in Federal Systems - Lessons for the European Union. Journal of European Public Policy. 24 (2017) No. 4: 520. 
28 BORANBAY-AKAN, Serra; König, Thomas; Osnabrügge, Moritz. The Imperfect AgendaSetter: Why do Legislative Proposals Fail in the EU Decision-Making Process? European Union Politics. 18 (2017) No. 2: 168.

29 BRESSERS, Luuk. Damages for Delay: The EU Held Liable for Harm Caused by 'Unjustified Inactivity' in General Court Proceedings. Journal of European Competition Law and Practice. 8 (2017) No. 8: 492.

30 BRKAN, Maja. The Unstoppable Expansion of the EU Fundamental Right to Data Protection: Little Shop of Horrors? Maastricht Journal of European and Comparative Law. 23 (2016) No. 5: 812.

31 BUNEA, Adriana. Designing Stakeholder Consultations: Reinforcing or Alleviating Bias in the European Union System of Governance? European Journal of Political Research. 56 (2017) No. 1: 46.

32 BÜRGIN, Alexander. Internal Coordination and Legitimation Strategies: Assessing the Influence of Individual Commissioners in the Policy Formulation Process. Journal of European Integration. 39 (2017) No. 1: 1.

33 CAMISÃO, Isabel; Guimarães, Maria Helena. The Commission, the Single Market and the Crisis: The Limits of Purposeful Opportunism. Journal of Common Market Studies. 55 (2017) No. 2: 223.

34 CARROLL, Brendan J.; Rasmussen, Anne. Cultural Capital and the Density of Organised Interests Lobbying the European Parliament. West European Politics. 40 (2017) No. 5: 1132.

35 CHAMON, Merijn. Institutional Balance and Community Method in the Implementation of EU Legislation Following the Lisbon Treaty. Common Market Law Review. 53 (2016) No. 6: 1501.

36 CINI, Michelle; Šuplata, Marián. Policy Leadership in the European Commission: The Regulation of EU Mobile Roaming Charges. Journal of European Integration. 39 (2017) No. 2: 143.

37 COSTA, Olivier. The Coming of Age of the European Parliament. Journal of European Integration. 39 (2017) No. 3: 365.

38 COTTER, John. 'Keep Calm and Carry On': EU Legal Developments in 2016. Journal of Common Market Studies. 55 (2017) No. S1: 88.

39 CRESPY, Amandine; Parks, Louisa. The Connection between Parliamentary and Extra-Parliamentary Opposition in the EU. From ACTA to the Financial Crisis. Journal of European Integration. 39 (2017) No. 4: 453.

40 CROMBEZ, Christophe; Huysmans, Martijn; Van Gestel, Wim. Choosing an Informative Agenda Setter: The Appointment of the Commission in the European Union. European Union Politics. 18 (2017) No. 2: 145.

41 CROSS, James P.; Hermansson, Henrik. Legislative Amendments and Informal Politics in the European Union: A Text Reuse Approach. European Union Politics. 18 (2017) No. 4: 581 .

42 CROWE, Richard. The European Council and the Multiannual Financial Framework. Cambridge Yearbook of European Legal Studies. 18 (2016): 45.

43 CSEHI, Robert. Horizontal Coordination in Federal Political Systems - NonCentralization in the European Union and Canada Compared. Journal of European Public Policy. 24 (2017) No. 4: 562.

44 CURTICE, John. Why Leave Won the UK's EU Referendum. Journal of Common Market Studies. 55 (2017) No. S1: 19.

45 CURTIN, Deirdre. 'Accountable Independence' of the European Central Bank: Seeing the Logics of Transparency. European Law Journal. 23 (2017) No. 1-2: 28. 
46 DALTON, Russell J. Citizens' Representation in the 2009 European Parliament Elections. European Union Politics. 18 (2017) No. 2: 188.

47 DAMMANN, Jens. Revoking Brexit: Can Member States Rescind Their Declaration of Withdrawal from the European Union. Columbia Journal of European Law. 23 (2017) No. 2: 265.

48 DAVID, Maxine; Drake, Helen. Foreword: 'Life Is Going to Be Different in the Future'. Journal of Contemporary European Research. 12 (2016) No. 4: 7 pp.

49 DE BRUYCKER, Iskander. Politicization and the Public Interest: When Do the Elites in Brussels Address Public Interests in EU Policy Debates? European Union Politics. 18 (2017) No. 4: 603.

50 DE LEÓN, Sergio Alonso. Four Decades of the European Electoral Act: A Look Back and a Look Ahead to an Unfulfilled Ambition. European Law Review. 42 (2017) No. 3: 353.

51 DE POLI, Matteo; Carabellese, Pierre de Gioia. The Minority Directors in the Corporate Governance of EU Listed Institutions: A Chimaera or a Possibility. Maastricht Journal of European and Comparative Law. 24 (2017) No. 1: 43.

52 DE VRIES, Catherine E. Benchmarking Brexit: How the British Decision to Leave Shapes EU Public Opinion. Journal of Common Market Studies. 55 (2017) No. S1: 38.

53 DE WITTE, Bruno. The Future of Variable Geometry in a Post-Brexit European Union. Maastricht Journal of European and Comparative Law. 24 (2017) No. 2: 153.

54 DECKARM, Renke. The Countries they Know Best: How National Principals Influence European Commissioners and their Cabinets. Journal of European Public Policy. 24 (2017) No. 3: 447.

55 DEMEDTS, Valerie; Chamon, Merijn. The Commission Back on the Leash: No Autonomy to Sign Non-Binding Agreements on Behalf of the EU: Council v. Commission. Common Market Law Review. 54 (2017) No. 1: 245.

56 DERMINE, Paul. The End of Impunity? The Legal Duties of 'Borrowed' EU Institutions under the European Stability Mechanism Framework: ECJ 20 September 2016, Case C-8/15 to C-10/15, Ledra Advertising et al. v European Commission and European Central Bank. European Constitutional Law Review. 13 (2017) No. 2: 369

57 DI DONATO, Luca. The Quality of Regulation in the Service of Preventing Corruption: Corruption Impact Assessment (CIA). European Journal of Law Reform. 18 (2016) No. 2: 226.

58 DINAN, Desmond. Leadership in the European Council: An Assessment of Herman Van Rompuy's Presidency. Journal of European Integration. 39 (2017) No. 2: 157.

59 DINAN, Desomond. Governance and Institutions: The Insidious Effect of Chronic Crisis. Journal of Common Market Studies. 55 (2017) No. S1: 73.

60 DOMORENOK, Ekaterina. Traps of Multi-Level Governance. Lessons from the Implementation of the Water Framework Directive in Italy. Journal of European Integration. 39 (2017) No. 6: 657.

61 DUMOULIN, Michel. La Crise Européenne de la Belgique à la Veille de la Signature des Traités de Rome. Journal of European Integration History. 23 (2017) No. 1: 29.

62 EGEBERG, Morten; Trondal, Jarle. Researching European Union Agencies: What Have We Learnt (and Where Do We Go from Here)? Journal of Common Market Studies. 55 (2017) No. 4: 675.

63 EISELE, Olga. Complementing, Competing, or Co-operating? Exploring Newspapers' Portrayals of the European Parliament and National Parliaments in EU Affairs. Journal of European Integration. 39 (2017) No. 4: 435.

64 ELEFTHERIADIS, Pavlos. Two Doctrines of the Unwritten Constitution. European Constitutional Law Review. 13 (2017) No. 3: 525. 
65 ELIANTONIO, Mariolina. Alternative Forms of Regulation: Are They Really 'Better' Regulation? European Journal of Law Reform. 19 (2017) No. 1-2: 141.

66 Eliantonio, Mariolina; Spendzharova, Aneta. The European Union's New 'Better Regulation' Agenda: Between Procedures and Politics. European Journal of Law Reform. 19 (2017) No. 1-2: 3.

67 FABBRINI, Sergio. Intergovernmentalism in the European Union. A Comparative Federalism Perspective. Journal of European Public Policy. 24 (2017) No. 4: 580.

68 FERRERA, Maurizio. Impatient Politics and Social Investment: The EU as 'Policy Facilitator'. Journal of European Public Policy. 24 (2017) No. 8: 1233.

69 FINKE, Daniel. Underneath the Culture of Consensus: Transparency, Credible Commitments and Voting in the Council of Ministers. European Union Politics. 18 (2017) No. 3: 339.

70 FOSSUM, John Erik. Democratic Federalization and the InterconnectednessConsent Conundrum. Journal of European Public Policy. 24 (2017) No. 4: 486.

71 FOSSUM, John Erik; Jachtenfuchs, Markus. Federal Challenges and Challenges to Federalism. Insights from the EU and Federal States. Journal of European Public Policy. 24 (2017) No. 4: 467.

72 FROMAGE, Diane. Increasing Inter-Parliamentary Cooperation in the European Union: Current Trends and Challenges. European Public Law. 22 (2016) No. 4: 749.

73 FROMAGE, Diane; FASONE, Cristina. The French and the Italian Parliaments in EU Affairs Post-Lisbon: True Empowerment or Cosmetic Change? Journal of Contemporary European Research. 13 (2017) No. 3: 16 pp.

74 GALPIN, Charlotte. Chronology: The European Union in 2016. Journal of Common Market Studies. 55 (2017) No. S1: 192.

75 GANDRUD, Christopher; O’Keeffe, Micheál. Information and Financial Crisis PolicyMaking. Journal of European Public Policy. 24 (2017) No. 3: 386.

76 GATTERMANN, Katjana; De Vreese, Claes H. The Role of Candidate Evaluations in the 2014 European Parliament Elections: Towards the Personalization of Voting Behaviour? European Union Politics. 18 (2017) No. 3: 447.

77 GAUCI, Jean-Pierre; Griffith, Arianne; McCorquodale, Robert. Brexit Financial Disputes and Public International Law. European Law Review. 42 (2017) No. 5: 619.

78 GEHLER, Michael. 'Europe', Europeanizations and their Meaning for European Integration Historiography. Journal of European Integration History. 22 (2016) No. 1: 141 .

79 GOLDMANN, Matthias. The Great Recurrence: Karl Polanyi and the Crises of the European Union. European Law Journal. 23 (2017) No. 3-4: 272.

80 GOLLATA, Judith A.M.; Newig, Jens. Policy Implementation through Multi-Level Governance: Analysing Practical Implementation of EU Air Quality Directives in Germany. Journal of European Public Policy. 24 (2017) No. 9: 1308.

81 GORDON, Michael. Brexit: A Challenge for the UK Constitution, of the UK Constitution? European Constitutional Law Review. 12 (2016) No. 3: 409.

82 HÄGE, Frank M. The Scheduling Power of the EU Council Presidency. Journal of European Public Policy. 24 (2017) No. 5: 695.

83 HÄKKINEN, Teemu. Embracing Values? The Question of Finnish Membership of the Council of Europe as a Case of Political Value Deliberation in European Integration, 1987-1989. Journal of European Integration History. 22 (2016) No. 1: 125. 
84 HANF, Dominik. Balancing Openness and Coherence of Enhanced Cooperation: The Principle of Coherence Affirmed by Drawing its Outer Limits: Spain v. Parliament and Council (Eurosur). Common Market Law Review. 54 (2017) No. 3: 873.

85 HARTLAPP, Miriam. How Time Empowers Agency: Combining the EU Commission's Political Powers and its Administration's Advantage of Acting from a Long-Term Perspective. Journal of European Integration. 39 (2017) No. 3: 303.

86 HARVEY, Darren. Towards Process-Oriented Proportionality Review In The European Union. European Public Law. 23 (2017) No. 1: 93.

87 HARVEY, Darren. What Role for the European Parliament under Article 50 TEU? European Law Review. 42 (2017) No. 4: 585.

88 HAUGHTON, Tim. Take Back Control: The European Union in 2016. Journal of Common Market Studies. 55 (2017) No. S1: 5.

89 HEIMS, Eva M. Regulatory Co-ordination in the EU: A Cross-Sector Comparison. Journal of European Public Policy. 24 (2017) No. 8: 1116.

90 HOFER, Katharina E.; Marti, Christian; Bütler, Monika. Ready to Reform: How Popular Initiatives Can be Successful. European Journal of Political Economy. (2017) No. 48: 16.

91 HÖGEnAUER, Anna-Lena. The European Parliament in Times of Crisis: Transnationalism under Pressure? Journal of Contemporary European Research. 13 (2017) No. 2: 19 pp.

$92 \mathrm{HOH}$, Anna-Lena. 'When Counting Counts' - Europeanisation of Census-Taking in Croatia, Bosnia and Herzegovina and the Former Yugoslav Republic of Macedonia. Journal of Contemporary European Research. 13 (2017) No. 1: 17 pp.

93 HOWARTH, David; Roos, Mechthild. Pushing the Boundaries. New Research on the Activism of EU Supranational Institutions. Journal of Contemporary European Research. 13 (2017) No. 2: 18 pp.

94 HUNT, Jo; MINTO, Rachel; Woolford, Jayne. Winners and Losers: The EU Referendum Vote and its Consequences for Wales. Journal of Contemporary European Research. 12 (2016) No. 4: 11 pp.

95 JACHTENFUCHS, Markus; Kasack, Christiane. Balancing Sub-Unit Autonomy and Collective Problem-Solving by Varying Exit and Voice. An Analytical Framework. Journal of European Public Policy. 24 (2017) No. 4: 598.

96 JANSSEN, André. Brexit: Der Herzinfarkt der Europäischen Union. European Review of Private Law. 24 (2016) No. 5: 731.

97 JARLB/EK PEDERSEN, Morten. Defining 'Better' Investigating a New Framework to Understand Quality of Regulation. European Journal of Law Reform. 18 (2016) No. 2: 159 .

98 JOACHIM, Bart. Europe's Executive in Stormy Weather: How does Politicization Affect Commission Officials' Attitudes? Comparative European Politics. 15 (2017) No. 4: 533.

99 JOERGES, Christian; Kreuder-Sonnen, Christian. European Studies and the European Crisis: Legal and Political Science between Critique and Complacency. European Law Journal. 23 (2017) No. 1-2: 118.

100 JOUAN, Quentin. Narratives of European Integration in Times of Crisis: Images of Europe in the 1970s. Journal of European Integration History. 22 (2016) No. 1: 11.

101 KAISER, Wolfram. Limits of Cultural Engineering: Actors and Narratives in the European Parliament's House of European History Project. Journal of Common Market Studies. 55 (2017) No. 3: 518. 
102 KAMKHAJI, Jonathan C.; Radaelli, Claudio M. Crisis, Learning and Policy Change in the European Union. Journal of European Public Policy. 24 (2017) No. 5: 714.

103 KANIOK, Petr. In the Shadow of Consensus: Communication within Council Working Groups. Journal of Contemporary European Research. 12 (2016) No. 4: 17 pp.

104 KASSIM, Hussein; Connolly, Sara; Dehousse, Reanud; Rozenberg, Olivier; Bendjaballah, Selma. Managing the House: The Presidency, Agenda Control and Policy Activism in the European Commission. Journal of European Public Policy. 24 (2017) No. 5: 653.

105 KEATING, Michael. Europe as a Multilevel Federation. Journal of European Public Policy. 24 (2017) No. 4: 615.

106 KELEMEN, R. Daniel; Blauberger, Michael. Introducing the Debate: European Union Safeguards Against Member States' Democratic Backsliding. Journal of European Public

107 KENTMEN-CIN, Cigdem. What about Ambivalence and Indifference? Rethinking the Effects of European Attitudes on Voter Turnout in European Parliament Elections. Journal of Common Market Studies. 55 (2017) No. 6: 1343.

108 KÖNIG, Thomas; Luig, Bernd. The Impact of EU Decision-Making on National Parties' Attitudes towards European Integration. European Union Politics. 18 (2017) No. 3: 362 .

109 KORKEA-AHO, Emilia. 'Mr Smith Goes To Brussels': Third Country Lobbying and the Making of EU Law and Policy. Cambridge Yearbook of European Legal Studies. 18 (2016): 45.

110 KORKEA-AHO, Emilia; Leino, Päivi. Who Owns the Information Held by EU Agencies? Weed Killers, Commercially Sensitive Information and Transparent and Participatory Governance. Common Market Law Review. 54 (2017) No. 4: 1059.

111 KOUTRAKOS, Panos. Public Disquiet and Treaty-Making. European Law Review. 42 (2017) No. 1: 1 .

112 KRAFT, Jonas. Social Democratic Austerity: The Conditional Role of Agenda Dynamics and Issue Ownership. Journal of European Public Policy. 24 (2017) No. 10: 1430 .

113 KRENN, Christoph. The European Court of Justice's Financial Accountability: How the European Parliament Incites and Monitors Judicial Reform through the Budgetary Process. European Constitutional Law Review. 13 (2017) No. 3: 453.

114 KUDRNA, Zdenek; Müller, Patrick. Harmonizing Internationally to Harmonize Internally: Accounting for a Global Exit from the EU's Decision Trap. Journal of Common Market Studies. 55 (2017) No. 4: 815.

115 KUTAY, Acar. How Does the European Commission Create a European Civil Society with Words? A Discourse Theoretical Inquiry. Journal of Common Market Studies. 55 (2017) No. 5: 1094.

116 ŁACNY, Justyna. Between the Devil and the Deep Blue Sea. The CJEU Case-Law on Financial Corrections Imposed by the Commission on the Member States. Journal of Contemporary European Research. 13 (2017) No. 2: 12 pp.

117 LORD, Christopher. An Indirect Legitimacy Argument for a Directly Elected European Parliament. European Journal of Political Research. 56 (2017) No. 3: 512.

118 LORD, Christopher. The Legitimacy of Exits from the European Union. Journal of European Integration. 39 (2017) No. 5: 499.

119 LOTH, Wilfried. 60 Years ago: The Foundation of EEC and EAEC as Crisis Management. Journal of European Integration History. 23 (2017) No. 1: 9.

120 LUHMANN, Sybille. The European Identity Survey - a Bridge between Political Science and Psychology. Journal of Contemporary European Research. 13 (2017) No. 3: $23 \mathrm{pp}$. 
121 MAJONE, Giandomenico. The European Union Post-Brexit: Static or Dynamic Adaptation? European Law Journal. 23 (2017) No. 1-2: 9.

122 MALANG, Thomas. Better = Faster? Explaining Citizens' Desired Speed of European Integration. Journal of European Integration. 39 (2017) No. 1: 17.

123 MARTINICO, Giuseppe. Asymmetry as an Instrument of Differentiated Integration: The Case of the European Union. European Journal of Law Reform. 18 (2016) No. 2: 139.

124 MCCANN, Adam P. Brexit, Higher Education, and Responsible Governance. European Journal of Comparative Law and Governance. 4 (2017) No. 3: 205 pp.

125 MCCREA, Ronan. Forward or Back: The Future of European Integration and the Impossibility of the Status Quo. European Law Journal. 23 (2017) No. 1-2: 66.

126 MENÉnDEZ, Agustín José. Democracy, Translucidity and Accountability: The Eurozone vs. The Democratic Right to Know. European Law Journal. 23 (2017) No. 1-2: 2 .

127 MEUWESSE, Anne C. M. Regulatory Review of European Commission Impact Assessments. European Journal of Law Reform. 19 (2017) No. 1-2: 16.

128 MIKLIN, Eric. Beyond Subsidiarity: The Indirect Effect of the Early Warning System on National Parliamentary Scutiny in European Union Affairs. Journal of European Public Policy. 24 (2017) No. 3: 366.

129 MILLER, Bowman H. Tomorrow's Europe: A Never Closer Union. Journal of European Integration. 39 (2017) No. 4: 421.

130 MOLONEY, Niamh. Brexit and EU Financial Governance: Business as Usual or Institutional Change? European Law Review. 42 (2017) No. 1: 112.

131 MÜHLBÖCK, Monika; Yordanova, Nikoleta. When Legislators Choose Not to Decide: Abstentions in the European Parliament. European Union Politics. 18 (2017) No. 2: 323.

132 MÜlLER, Henriette. Setting Europe's Agenda: The Commission Presidents and Political Leadership. Journal of European Integration. 39 (2017) No. 2: 129.

133 MURPHY, Mary C. The EU Referendum in Northern Ireland: Closing Borders, ReOpening Border Debates. Journal of Contemporary European Research. 12 (2016) No. 4: $10 \mathrm{pp}$.

134 NANOU, Kyriaki; Zapryanova, Galina; Toth, Fanni. An Ever-Closer Union? Measuring the Expansion and Ideological Content of European Union Policy-Making through an Expert Survey. European Union Politics. 18 (2017) No. 4: 678.

135 NEDERGAARD, Peter; Dagnis Jensen, Mads. You're Gonna Have to Serve Somebody: A Comparative Analysis of the Polish, Danish and Cypriot EU Presidency Discourses. Comparative European Politics. 15 (2017) No. 2: 286.

136 NICE, Geoffrey. The UK's Departure from the EU May Be a Matter of Impression. New Journal of European Criminal Law. 8 (2017) No. 2: 104.

137 NICOLAIDES, Phedon. The Day after: Exit-Induced Legal Lacuna. Maastricht Journal of European and Comparative Law. 24 (2017) No. 2: 158.

138 NICOLI, Francesco. Democratic Legitimacy in the Era of Fiscal Integration. Journal of European Integration. 39 (2017) No. 4: 389.

139 NITOIU, Cristian; Sus, Monika. The European Parliament's Diplomacy - a Tool for Projecting EU Power in Times of Crisis? The Case of the Cox-Kwasniewski Mission. Journal of Common Market Studies. 55 (2017) No. 1: 71.

140 OBERLOSKAMP, Eva. The European TREVI Conference in the 1970s: Transgovernmental Policy Coordination in the Area of Internal Security. Journal of European Integration History. 22 (2016) No. 1: 29. 
141 OLSEN, Johan P. Democratic Accountability and the Changing European Political Order. Arena Working Papers. (2017) No. 8: 40 pp.

142 OSTENDORF, Patrick. The Withdrawal Cannot be Withdrawn: The Irrevocability of a Withdrawal Notification under art. 50(2) TEU. European Law Review. 42 (2017) No. 5: 767.

143 OTT, Andrea. The European Parliament's Role in EU Treaty-Making. Maastricht Journal of European and Comparative Law. 23 (2016) No. 6: 1009.

144 PANNICO, Roberto. Is the European Union Too Complicated? Citizens' Lack of Information and Party Cue Effectiveness. European Union Politics. 18 (2017) No. 3: 424.

145 PARIS, Sidonie. The European Commission and the Blue Card Directive: Supranational policy entrepreneurship in troubled waters. Journal of Contemporary European Research. 13 (2017) No. 2: 18 pp.

146 PAUL, Regine. Harmonisation by Risk Analysis? Frontex and the Risk-Based Governance of European Border Control. Journal of European Integration. 39 (2017) No. 6: 689 .

147 PEERS, Steve; Costa, Marios. Reassessing the Accountability of European Union Decentralized Agencies: Mind the Independence Gap. European Public Law. 22 (2016) No. 4: 645.

148 PEGAN, Andreja. The Bureaucratic Growth of the European Union. Journal of Contemporary European Research. 13 (2017) No. 2: 27 pp.

149 PEGAN, Andreja. The Role of Personal Parliamentary Assistants in the European Parliament. West European Politics. 40 (2017) No. 2: 295.

150 PEREZ, Lauren K.; Scherpereel, John A. Vertical Intra-Institutional Effects of Ministerial Turnover in the Council of the European Union. Journal of European Public Policy. 24 (2017) No. 8: 1154.

151 PETERSON, John. Juncker's political European Commission and an EU in Crisis. Journal of Common Market Studies. 55 (2017) No. 2: 349.

152 PILICH, Mateusz. Brexit and EU Private International Law - May the UK Stay in? Maastricht Journal of European and Comparative Law. 24 (2017) No. 3: 382.

153 PIQUET, Agathe. Supranational Activism as an Assertion Process? The Case of Europol. Journal of Contemporary European Research. 13 (2017) No. 2: 23 pp.

154 POMORSKA, Karolina; Noutcheva, Gergana. Europe as a Regional Actor: Waning Influence in an Unstable and Authoritarian Neighbourhood. Journal of Common Market Studies. 55 (2017) No. S1: 165.

155 PRAINO, Diego. A New System of Government? Defining the Confidence Relationship of the EU Model. Journal of European Integration. 39 (2017) No. 3: 319.

156 QUAGLIA, Lucia; Spendzharova, Aneta. The Conundrum of Solving 'Too Big to Fail' in the European Union: Supranationalization at Different Speeds. Journal of Common Market Studies. 55 (2017) No. 5: 1110.

157 RAITIO, Juha; Raulus, Helena. The UK EU Referendum and the Move towards Brexit. Maastricht Journal of European and Comparative Law. 24 (2017) No. 1: 25.

158 RAMÍREZ-PÉREZ, Sigfrido. Multinational Corporations and European Integration: The Case of the Automobile Industry, 1959-1965. Journal of European Integration History. 22 (2016) No. 2: 329.

159 ROEDERER-RYNNING, Christilla; Greenwood, Justin. The European Parliament as a Developing Legislature: Coming of Age in Trilogues? Journal of European Public Policy. 24 (2017) No. 5: 735. 
160 ROGER, Léa; Otjes, Simon; van der Veer, Harmen. The Financial Crisis and the European Parliament: An Analysis of the Two-Pack Legislation. European Union Politics. 18 (2017) No. 4: 560.

161 ROOS, Mechthild. Far Beyond the Treaties' Clauses: The European Parliaments' Gain in Power, 1952-1979. Journal of Contemporary European Research. 13 (2017) No. 2: $21 \mathrm{pp}$.

162 ROSAMOND, Ben. Brexit and the Problem of European Disintegration. Journal of Contemporary European Research. 12 (2016) No. 4: 8 pp.

163 ROSÉN, Guri. The Impact of Norms on Political Decision-Making: How to Account for the European Parliament's Empowerment in EU External Trade Policy. Journal of European Public Policy. 24 (2017) No. 10: 1450.

164 ROSS, George; Jenson, Jane. Reconsidering Jacques Delors' Leadership of the European Union. Journal of European Integration. 39 (2017) No. 2: 113.

165 SANCHEZ-GRAELLS, Albert. Assessing the Public Administration's Intention in EU Economic Law: Chasing Ghosts or Dressing Windows? Cambridge Yearbook of European Legal Studies. 18 (2016): 93.

166 SCHLIPPHAK, Bernd; Treib, Oliver. Playing the Blame Game on Brussels: The Domestic Political Effects of EU Interventions Against Democratic Backsliding. Journal of European Public Policy. 24 (2017) No. 3: 352.

167 SCHOLTEN, Miroslava; Scholten, Daniel. From Regulation to Enforcement in the EU Policy Cycle: A New Type of Functional Spillover? Journal of Common Market Studies. 55 (2017) No. 4: 925.

168 SCHÖNLAU, Justus. Beyond Mere 'Consultation': Expanding the European Committee of the Regions' Role. Journal of Contemporary European Research. 13 (2017) No. 2: 19 pp.

169 SCHÖN-QUINLIVAN, Emmanuelle; Scipioni, Marco. The Commission as Policy Entrepreneur in European Economic Governance: A Comparative Multiple Stream Analysis of the 2005 and 2011 Reform of the Stability and Growth Pact. Journal of European Public Policy. 24 (2017) No. 8: 1172.

170 SCHOUT, Adriaan. The Dutch EU Presidency: The Continuing Relevance of the Rotating Presidency in a Political Union. Journal of Common Market Studies. 55 (2017) No. S1: 54

171 SHACKLETON, Michael. Britain in Brussels after the Referendum: Insider or Outsider? Journal of Contemporary European Research. 12 (2016) No. 4: 8 pp.

172 SHACKLETON, Michael. Transforming Representative Democracy in the EU? The Role of the European Parliament. Journal of European Integration. 39 (2017) No. 2: 191.

173 SIMPSON, Kathryn; Loveless, Matthew. Another Chance? Concerns about Inequality, Support for the European Union and Further European Integration. Journal of European Public Policy. 24 (2017) No. 7: 1069.

174 SMISMANS, Stijn. The Politicization of Ex Post Policy Evaluation in the EU. European Journal of Law Reform. 19 (2017) No. 1-2: 74.

175 SMITH, Simon J. If We Cannot Have Both, Then Which Union Do We Choose? Scotland's Options after 'Brexit'. Journal of Contemporary European Research. 12 (2016) No. 4: 10 pp.

176 SNELL, Jukka. Why Does the EU Keep Losing in Referenda, and What to Do About It? European Law Review. 41 (2016) No. 6: 779.

177 SOARES, Anthony. Living Within and Outside Unions: The Consequences of Brexit for Northern Ireland. Journal of Contemporary European Research. 12 (2016) No. 4: 9 pp. 
178 SPOON, Jae-Jae; Williams, Christopher. It Takes Two: How Eurosceptic Public Opinion and Party Divisions Influence Party Positions. West European Politics. 40 (2017) No. 4: 741.

179 STAAT, Christian; Kuehnhanss, Colin R. Outside Earnings, Electoral Systems and Legislative Effort in the European Parliament. Journal of Common Market Studies. 55 (2017) No. 2: 368.

180 STEINEBACH, Yves; Knill, Christoph. Still an Entrepreneur? The Changing Role of the European Commission in EU Environmental Policy-Making. Journal of European Public Policy. 24 (2017) No. 3: 429.

181 STEPHENSON, Paul. Norms, Legitimacy and Institutional Independence: The Active Role of the European Court of Auditors in Setting International Standards. Journal of Contemporary European Research. 13 (2017) No. 2: 22 pp.

182 STEPHENSON, Paul. Why Better Regulation Demands Better Scrutiny of Results: The European Parliament's Use of Performance Audits by the European Court of Auditors in Ex Post Impact Assessment. European Journal of Law Reform. 19 (2017) No. 1-2: 97.

183 STROß, Simon. Royal Roads and Dead Ends. How Institutional Procedures Influence the Coherence of European Union Policy Formulation. Journal of European Integration. 39 (2017) No. 3: 333.

184 ŠVIK, Peter. Early European Summitry and the Making of the Council of Europe. Journal of European Integration History. 22 (2016) No. 1: 107.

185 TADEUSZ KONCEWICZ, Tomasz. Of Institutions, Democracy, Constitutional SelfDefence and the Rule of law: The Judgments of the Polish Constitutional Tribunal in Cases K 34/15, K 35/15 and Beyond. Common Market Law Review. 53 (2016) No. 6: 1753.

186 TAKE, Ingo. The Hanseatic League as an Early Example of Cross-Border Governance? Journal of European Integration History. 23 (2017) No. 1: 71.

187 TATHAM, Michaël. Networkers, Fund Hunters, Intermediaries, or Policy Players? The Activities of Regions in Brussels. West European Politics. 40 (2017) No. 5: 1088.

188 TEGELAAR, J.T.; Haentjens, M. Brexit and the City. Review of European Administrative Law. 10 (2017) No. 2: 350.

189 THEUNS, Tom; DE JONGH, Maurits. Democratic Legitimacy, Desirability and Deficit in EU Governance. Journal of Contemporary European Research. 13 (2017) No. 3: $18 \mathrm{pp}$.

190 THIEMEYER, Guido. Die „Volonté Générale“, das Europäische Staatensystem und die Genese Supranationaler Internationaler Organisationen vom Frühen 19. Jahrhundert bis in die Mitte des 20. Jahrhunderts. Journal of European Integration History. 22 (2016) No. 2: 229.

191 THOMANN, Eva; Sager, Fritz. Moving Beyond Legal Compliance: Innovative Approaches to EU Multilevel Implementation. Journal of European Public Policy. 24 (2017) No. 9: 1253.

192 THOMANN, Eva; Zhelyazkova, Asya. Moving Beyond (Non-)Compliance: The Customization of European Union Policies in 27 Countries. Journal of European Public Policy. 24 (2017) No. 9: 1269.

193 THOMAS, Richard; Turnbull, Peter. Talking up a Storm? Using Language to Activate Adherents and Demobilize Detractors of European Commission Policy Frames. Journal of European Public Policy. 24 (2017) No. 7: 931.

194 THORLAKSON, Lori. Representation in the EU: Multi-Level Challenges and New Perspectives from Comparative Federalism. Journal of European Public Policy. 24 (2017) No. 4: 544. 
195 TÖMMEL, Ingeborg. The Standing President of the European Council: Intergovernmental or Supranational Leadership? Journal of European Integration. 39 (2017) No. 2: 175.

196 TÖMMEL, Ingeborg; Verdun, Amy. Political Leadership in the European Union: An Introduction. Journal of European Integration. 39 (2017) No. 2: 103.

197 TOSHKOV, Dimiter D. The Impact of the Eastern Enlargement on the DecisionMaking Capacity of the European Union. Journal of European Public Policy. 24 (2017) No. 2: 177.

198 TOVO, Carlo. Delegation of Legislative Powers in the EU: How EU Institutions Have Eluded the Lisbon Reform. European Law Review. 42 (2017) No. 5: 677.

199 TULLI, Umberto. The European Parliament and the European Political Cooperation. The Search for a Proper Role in the Community's First Foreign Policy. Journal of Contemporary European Research. 13 (2017) No. 2: 14 pp.

200 TURENNE, Sophie. Institutional Constraints and Collegiality at the Court of Justice of the European Union. A Sense of Belonging? Maastricht Journal of European and Comparative Law. 24 (2017) No. 4: 565.

201 VAN BALLAERT, Bart. The European Commission's Use of Consultation during Policy Formulation: The Effects of Policy Characteristics. European Union Politics. 18 (2017) No. 3: 406.

202 VAN DEN BERGH, Roger. Farewell Utopia? Why the European Union Should Take the Economics of Federalism Seriously. Maastricht Journal of European and Comparative Law. 23 (2016) No. 6: 937.

203 VAN ESCH, F.A.W.J. The Paradoxes of Legitimate EU Leadership. An Analysis of the Multi-Level Leadership of Angela Merkel and Alexis Tsipras during the Euro Crisis. Journal of European Integration. 39 (2017) No. 2: 223.

204 VAN VOORST, Stijn; Mastenbroek, Ellen. Enforcement Tool or Strategic Instrument? The Initiation of Ex-post Legislative Evaluations by the European Commission. European Union Politics. 18 (2017) No. 4: 640.

205 VASIlOPOUlOU, Sofia; Wagner, Markus. Fear, Anger and Enthusiasm about the European Union: Effects of Emotional Reactions on Public Preferences towards European Integration. European Union Politics. 18 (2017) No. 3: 382.

206 VERBRUGGEN, Paul. Private Regulation in EU Better Regulation Past Performance and Future Promises. European Journal of Law Reform. 19 (2017) No. 1-2: 121.

207 Vestlund, Nina M. Pooling Administrative Resources through EU Regulatory Networks. Journal of European Public Policy. 24 (2017) No. 1: 61.

208 VOGIATZIS, Nikos. Between Discretion and Control: Reflections on the Institutional Position of the Commission within the European Citizens' Initiative Process. European Law Journal. 23 (2017) No. 3-4: 250.

209 VOSA, Giuliano. Delegation or Implementation? The Ambiguous Divide. European Law Review. 42 (2017) No. 5: 737.

210 WAGNER, Wolfgang. Liberal Power Europe. Journal of Common Market Studies. 55 (2017) No. 6: 1398.

211 WALLACE, Helen. Heading for the Exit: The United Kingdom's Troubled Relationship with the European Union. Journal of Contemporary European Research. 12 (2016) No. 4: 7 pp.

212 WALLACE, Helen. The JCMS Annual Review Lecture: In the Name of Europe. Journal of Common Market Studies. 55 (2017) No. S1: 8.

213 WARNTJEN, Andreas. Do Votes Matter? Voting Weights and the Success Probability of Member State Requests in the Council of the European Union. Journal of European Integration. 39 (2017) No. 6: 673. 
214 WARNTJEN, Andreas. Why No Gridlock? Coping with Diversity in the Council of the European Union. Journal of Contemporary European Research. 13 (2017) No. 1: 17 pp.

215 WHELANOVÁ, Markéta. Quo Vadis, Europa? Loopholes in the EU Law and Difficulties in the Implementation Process. European Journal of Law Reform. 18 (2016) No. 2: 179.

216 WHITAKER, Richard; Hix, Simon; Zapryanova, Galina. Understanding Members of the European Parliament: Four Waves of the European Parliament Research Group MEP Survey. European Union Politics. 18 (2017) No. 3: 491.

217 WOODHOUSE, Andrew. With Great Power, Comes No Responsibility? The 'Political Exception' to Duties of Sincere Cooperation for National Parliaments. Common Market Law Review. 54 (2017) No. 2: 443.

218 ZIELONKA, Jan. The Remaking of the EU's Borders and the Images of European Architecture. Journal of European Integration. 39 (2017) No. 5: 641.

219 ZILLER, Jacques. Institutional Balance,Territorial Scope and Derogations to EU Law: Parliament \& Commission v. Council (Mayotte). Common Market Law Review. 54 (2017) No. 5: 1497.

\section{People and Politics}

(Justice and Home Affairs / Asylum, refugees, external frontiers and immigration / Citizen's Europe / Politics in Europe / Human rights and fundamental freedoms / Racism / Terrorism / Religion / Public administration / Lobbying / Regional and local government)

220 ADAM, Silke; Antl-Wittenberg, Eva-Maria; Eugster, Beatrice; Leidecker-Sandmann, Melanie; Maier, Michaela; Schmidt, Franzisca. Strategies of Pro-European Parties in the Face of a Eurosceptic Challenge. European Union Politics. 18 (2017) No. 2: 260.

221 AGERBERG, Mattias. Failed Expectations: Quality of Government and Support for Populist Parties in Europe. European Journal of Political Research. 56 (2017) No. 3: 578.

222 ALlEN, Peter; Cutts, David. How Do Gender Quotas Affect Public Support for Women as Political Leaders? West European Politics. 41 (2018) No. 1: 147.

223 ALONSO, Sonia; Cabeza, Laura; Gómez, Braulio. Disentangling Peripheral Parties' Issue Packages in Subnational Elections. Comparative European Politics. 15 (2017) No. 2: 240 .

224 ANAGNOSTARAS, Georgios. Mutual Confidence is not Blind Trust! Fundamental Rights Protection and the Execution of the European Arrest Warrant: Aranyosi and Caldararu. Common Market Law Review. 53 (2016) No. 6: 1675.

225 ANAGNOSTARAS, Georgios. Solange III? Fundamental Rights Protection Under the National Identity Review. European Law Review. 42 (2017) No. 2: 234.

226 ANDERSON, Alan B. The Migrant Crisis and Ethnic Minority Integration in Europe Commentary. Journal of Ethnopolitics and Minority Issues in Europe. 16 (2017) No. 2: 108.

227 ANDEVA, Marina. Can Migration Jeopardize Basic Human Rights: The Situation of the Roma Minority in Macedonia. Journal of Ethnopolitics and Minority Issues in Europe. 16 (2017) No. 2: 67.

228 ANDRÉ, Audrey; Depauw, Sam. Too Much Choice, Too Little Impact: A Multilevel Analysis of the Contextual Determinants of Preference Voting. West European Politics. 40 (2017) No. 3: 598. 
229 ANDREADAKIS, Stelios; Morrison, Scott. Whistleblowers Under the Spotlight. European Journal of Comparative Law and Governance. 3 (2016) No. 4: 353 pp.

230 ANGELERI, Stefano. The Impact of the Economic Crisis on the Right to Health of Irregular Migrants, as Reflected in the Jurisprudence of the UN Committee on Economic, Social and Cultural Rights. European Journal of Migration and Law. 19 (2017) No. 2: 165

231 ARNDT, Christoph. Public Policy-Making and Risk Profiles: Scandinavian CentreRight Governments after the Turn of the Millennium. European Political Science Review. 9 (2017) No. 4: 495.

232 ARNOLD, Tobias; Stadelmann-Steffen, Isabelle. How Federalism Influences Welfare Spending: Belgium Federalism Reform through the Perspective of the Synthetic Control Method. European Journal of Political Research. 56 (2017) No. 3: 680.

233 ARRIGHI, Jean-Thomas; Bauböck, Rainer. A Multilevel Puzzle: Migrants' Voting Rights in National and Local Elections. European Journal of Political Research. 56 (2017) No. 3: 619.

234 ASATRYAN, Zareh; Heinemann, Friedrich; Pitlik, Hans. Reforming the Public Administration: The Role of Crisis and the Power of Bureaucracy. European Journal of Political Economy. (2017) No. 48:128.

235 AZROUT, Rachid; Wojcieszak, Magdalena E. What's Islam Got to do With it? Attitudes toward Specific Religious and National Out-Groups, and Support for EU Policies. European Union Politics. 18 (2017) No. 1: 51.

236 AZRROUT, Rachid; de Vreese, Claes. The Moderating Role of Identification and Campaign Exposure in Party Cueing Effects. West European Politics. 41 (2018) No. 2: 384 .

237 BAIRD, Theodore. Carrier Sanctions in Europe: A Comparison of Trends in 10 Countries. European Journal of Migration and Law. 19 (2017) No. 3: 307.

238 BALESTRINI, Pierre P. Public Opinion in Europe in Quest of Harmony? Comparative European Politics. 14 (2016) No. 6: 735.

239 BAULOZ, Céline. Foreigners: Wanted Dead or Alive?: Medical Cases before European Courts and the Need for an Integrated Approach to Non-Refoulement. European Journal of Migration and Law. 18 (2016) No. 4: 409.

240 BAUMGARTNER, Frank R.; Carammia, Marcello; Epp, Derek A.; Noble, Ben; Rey, Beatriz; Murat Yildrim, Tevfik. Budgetary Change in Authoritarian and Democratic Regimes. Journal of European Public Policy. 24 (2017) No. 6: 792.

241 BAYRAM, A. Burcu. Good Europeans? How European Identity and Costs Interact to Explain Politician Attitudes towards Compliance with European Union Law. Journal of European Public Policy. 24 (2017) No. 1: 42.

242 BEAUDONNET, Laurie; Gomez, Raul. Red Europe Versus no Europe? The Impact of Attitudes towards the EU and the Economic Crisis on Radical-Left Voting. West European Politics. 40 (2017) No. 2: 316.

243 BECH SEEBERG, Henrik; Slothuus, Rune; Stubager, Rune. Do Voters Learn? Evidence that Voters Respond Accurately to Changes in Political Parties' Policy Positions. West European Politics. 40 (2017) No. 2: 336.

244 BECHER, Michael; Brouard, Sylvain; Guinaudeau, Isabelle. Prime Ministers and the Electoral Cost of Using the Confidence Vote in Legislative Bargaining: Evidence from France. West European Politics. 40 (2017) No. 2: 252.

245 BECHTEL, Michael M.; Hainmueller, Jens; Margalit, Yotam. Policy Design and Domestic Support for International Bailouts. European Journal of Political Research. 56 (2017) No. 4: 864. 
246 BECKMANN, Joscha; Ademmer, Esther; Belke, Ansgar; Schweickert, Rainer. The Political Economy of the Impossible Trinity. European Journal of Political Economy. (2017) No. 47: 103.

247 BELL, John. Secularism French Style. European Public Law. 23 (2017) No. 2: 237.

248 BELLAMY, Richard; Lacey, Joseph; Nicolaïdis, Kalypso. European Boundaries in Question? Journal of European Integration. 39 (2017) No. 5: 483.

249 BELOT, Céline; Guinaudeau, Isabelle. Instrumental Political Support: Bringing Policy Preferences Back into Explanations of EU Support. West European Politics. 40 (2017) No. 4: 763.

250 BENNETT, Daniel L.; Nikolaev, Boris; Aidt, Toke S. Institutions and Well-Being. European Journal of Political Economy. (2016) No. 45 S1: 1.

251 BERGH, Adreas; Dackehag, Margareta; Rode, Martin. Are OECD Policy Recommendations for Public Sector Reform Biased Against Welfare States? Evidence from a New Database. European Journal of Political Economy. (2017) No. 48: 3 .

252 BERNAUER, Julian; Vatter, Adrian. Conflict, Choice or Geography? Explaining Patterns of Democracy in Continental Europe. European Journal of Political Research. 56 (2017) No. 2: 251.

253 BERTSOU, Eri; Pastorella, Giulia. Technocratic Attitudes: A Citizens' Perspective of Expert Decision-Making. West European Politics. 40 (2017) No. 2: 430.

254 BHATTI, Yosef; Olav Dahlgaard, Jens; Hedegaard Hansen, Jonas; Hansen, Kasper M. Can Governments Use Get Out The Vote Letters to Solve Europe's Turnout Crisis? Evidence from a Field Experiment. West European Politics. 41 (2018) No. 1: 240.

255 BIERBACH, Jeremy B. The Reality Test of Residence goes through the Looking Glass: Court of Justice of the European Free Trade Association States (EFTA Court), judgment of 26 July 2016, Case E-28/15, Yankuba Jabbi v The Norwegian Government, represented by the Immigration Appeals Board. European Constitutional Law Review. 13 (2017) No. 2: 383.

256 BISCHOF, Daniel. Ideological Congruence between Party Rhetoric and PolicyMaking. West European Politics. 41 (2018) No. 2: 310.

257 BJØRNSKOV, Christian. Economic Freedom and Economic Crises. European Journal of Political Economy. (2016) No. 45 Supplement: 11.

258 BLAUBERGER, Michael; Kelemen, R. Daniel. Can Courts Rescue National Democracy? Judicial Safeguards Against Democratic Backsliding in the EU. Journal of European Public Policy. 24 (2017) No. 3: 321.

259 BLOODGOOD, Elizabeth; Tremblay-Boire, Joannie. Does Government Funding Depoliticize Non-Governmental Organizations? Examining Evidence from Europe. European Political Science Review. 9 (2017) No. 3: 401.

260 BOLLEYER, Nicole; Smirnova, Valeria. Parliamentary Ethics Regulation and Trust in European Democracies. West European Politics. 40 (2017) No. 6: 1218.

261 BOROŃSKA-HRYNIEWIECKA, Karolina. Differential Europeanization? Explaining the Impact of the Early Warning System on Subnational Parliaments in Europe. European Political Science Review. 9 (2017) No. 2: 255.

262 BOSCO, Anna; Verney, Susannah. From Electoral Epidemic to Government Epidemic: The Next Level of the Crisis in Southern Europe. South European Society and Politics. 21 (2016) No. 4: 383.

263 BOSWELL, Christina; Hampshire, James. Ideas and Agency in Immigration Policy: A Discursive Institutionalist Approach. European Journal of Political Research. 56 (2017) No. 1: 133 . 
264 BOSWELL, John; Corbett, Jack. Why and How to Compare Deliberative Systems. European Journal of Political Research. 56 (2017) No. 4: 801.

265 BOURNE, Angela K.; Casal Bértoa, Fernando. Mapping 'Militant Democracy': Variation in Party Ban Practices in European Democracies (1945-2015). European Constitutional Law Review. 13 (2017) No. 2: 221.

266 BOUTLER, Catilin. Media Discourse and the Question of (New) Minority Definitions: Three Methodological Approaches. Journal of Ethnopolitics and Minority Issues in Europe. 16 (2017) No. 2: 87.

267 BOWLER, Shaun; Denemark, David; Donovan, Todd; McDonnell, Duncan. RightWing Populist Party Supporters: Dissatisfied but not Direct Democrats. European Journal of Political Research. 56 (2017) No. 1: 70.

268 BRAGA, Michela; Scervini, Francesco. The Performance of Politicians: The Effect of Gender Quotas. European Journal of Political Economy. (2017) No. 46: 1.

269 BRKAN, Maja. The Unstoppable Expansion of the EU Fundamental Right to Data Protection: Little Shop of Horrors? Maastricht Journal of European and Comparative Law. 23 (2016) No. 5: 812.

270 BRUZELIUS, Cecilia; Reinprecht, Constantin; Seeleib-Kaiser, Martin. Stratified Social Rights Limiting EU Citizenship. Journal of Common Market Studies. 55 (2017) No. 6: 1239.

271 BUCUR, Cristina. Cabinet Ministers Under Competing Pressures: Presidents, Prime Ministers, and Political Parties in Semi-Presidential Systems. Comparative European Politics. 15 (2017) No. 2: 180.

272 CAMERON, Iain. Balancing Data Protection and Law Enforcement Needs: Tele2 Sverige and Watson. Common Market Law Review. 54 (2017) No. 5: 1467.

273 CARLIER, Jean-Yves; Leboeuf, Luc. Choice of Residence for Refugees and Subsidiary Protection Beneficiaries; Variations on the Equality Principle: Alo and Osso. Common Market Law Review. 54 (2017) No. 2: 631.

274 CARLONI, Enrico; Giglioni, Fabio. Three Transparencies and the Persistence of Opacity in the Italian Government System. European Public Law. 23 (2017) No. 2: 285.

275 CARLSSON, Nina. Navigating Two Languages - Immigrant Integration Policies in Bilingual Finalnd. Journal of Ethnopolitics and Minority Issues in Europe. 16 (2017) No. 2: 41 .

276 CARRERAS, Miguel. Institutions, Governmental Performance and the Rise of Political Newcomers. European Journal of Political Research. 56 (2017) No. 2: 364.

277 CARSTENSEN, Martin B. Institutional Bricolage in Times of Crisis. European Political Science Review. 9 (2017) No. 1: 139.

278 CASAL BÉRTOA, Fernando. Political Parties or Party Systems? Assessing the 'Myth' of Institutionalisation and Democracy. West European Politics. 40 (2017) No. 2: 402 .

279 CASAL BÉRTOA, Fernando; Bourne, Angela. Prescribing Democracy? Party Proscription and Party System Stability in Germany, Spain and Turkey. European Journal of Political Research. 56 (2017) No. 2: 440.

280 CASTELLI GATTINARA, Pietro. Framing Exclusion in the Public Sphere: Far-Right Mobilisation and the Debate on Charlie Hebdo in Italy. South European Society and Politics. 22 (2017) No. 3: 345.

281 CECCARINI, Luigi; Bordignon, Fabio. Referendum on Renzi: The 2016 Vote on the Italian Constitutional Revision. South European Society and Politics. 22 (2017) No. 3: 281 . 
282 CEKIK, Aneta. Adapting to Europe? Business Interests and Civil Society Groups in Accession Countries. West European Politics. 40 (2017) No. 5: 1066.

283 CELLINI, Marco. Filling the Gap of the Dublin System: A Soft Cosmopolitan Approach. Journal of Contemporary European Research. 13 (2017) No. 1: 19 pp.

284 CERINA, Fabio; Deidda, Luca G. Rewards from Public Office and the Selection of Politicians by Parties. European Journal of Political Economy. (2017) No. 47: 1.

285 CERON, Andrea; Negri, Fedra. March Divided, Fight United? Trade Union Cohesion and Government Appeal for Concertation. West European Politics. 41 (2018) No. 1: 218.

286 CHARALAMBOUS, Giorgos; Lamprianou, Iasonas. The (Non) Particularities of West European Radical Left Party Supporters: Comparing Left Party Families. European Political Science Review. 9 (2017) No. 3: 375.

287 CHRISTMANN, Pablo; Torcal, Mariano. The Political and Economic Causes of Satisfaction with Democracy in Spain - a Twofold Panel Study. West European Politics. 40 (2017) No. 6: 1241.

288 CIACCHI, Aurelia Colombi. Political Parties' Programmes: Examples of Governance against Human Rights [Editorial]. European Journal of Comparative Law and Governance. 4 (2017) No. 2: 105 pp.

289 CIORNEI, Irina; Recchi, Ettore. At the Source of European Solidarity: Assessing the Effects of Cross-border Practices and Political Attitudes. Journal of Common Market Studies. 55 (2017) No. 3: 468.

290 CLARK, Alistair. Identifying the Determinants of Electoral Integrity and Administration in Advanced Democracies: The Case of Britain. European Political Science Review. 9 (2017) No. 3: 471.

291 CLÒ, Stefano; Fiorio, Carlo V.; Florio, Massimo. The Targets of State Capitalism: Evidence from M\&A Deals. European Journal of Political Economy. (2017) No. 47: 61.

292 CLOOTS, Elke. The Legal Limits of Citizenship Deprivation as a Counterterror Strategy. European Public Law. 23 (2017) No. 1: 57.

293 CLOSA, Carlos. Changing EU Internal Borders through Democratic Means. Journal of European Integration. 39 (2017) No. 5: 515.

294 COFFÉ, Hilde; Van Den Berg, Job. Understanding Shifts in Voting Behaviour Away from and Towards Radical Right Populist Parties: The Case of the PVV Between 2007 and 2012. Comparative European Politics. 15 (2017) No. 6: 872.

295 COPELAND, Paul; Copsey, Nathaniel. Rethinking Britain and the European Union: Politicians, the Media and Public Opinion Reconsidered. Journal of Common Market Studies. 55 (2017) No. 4: 709.

296 CORDERO, Guillermo; Blais, André. Is a Corrupt Government Totally Unacceptable? West European Politics. 40 (2017) No. 4: 645.

297 CSÚRI, András. The Proposed European Public Prosecutor's Office - from a Trojan Horse to a White Elephant? Cambridge Yearbook of European Legal Studies. 18 (2016): 122 .

298 CAPETA, Tamara. Brexit and the EU Constitutional Order: A Three Act Tragedy. Croatian Yearbook of European Law and Policy. 12 (2016): 1.

299 DAENEKINDT, Stijn; de Koster, Willem; van der Waal, Jeroen. How People Organise Cultural Attitudes: Cultural Belief Systems and the Populist Radical Right. West European Politics. 40 (2017) No. 4: 791.

300 DALlA PELlEGRINA, Lucia; De Mot, Jef; Faure, Michael; Garoupa, Nuno. Litigating Federalism: An Empirical Analysis of Decisions of the Belgian Constitutional Court. European Constitutional Law Review. 13 (2017) No. 2: 305. 
301 DAMHUIS, Koen; Karremans, Johannes. Responsive to whom? A Comparison of the Mitterrand and Hollande Presidencies. West European Politics. 40 (2017) No. 6: 1267.

302 DASSONNEVILLE, Ruth; Hooghe, Marc. Economic Indicators and Electoral Volatility: Economic Effects on Electoral Volatility in Western Europe, 19502013. Comparative European Politics. 15 (2017) No. 6: 919.

303 DASSONNEVILLE, Ruth; Hooghe, Marc; Lewis-Beck, Michael S. Do Electoral Rules Have an Effect on Electoral Behaviour? An Impact Assessment. West European Politics. 40 (2017) No. 3: 503.

304 DASSONNEVILLE, Ruth; Hooghe, Marc; Miller, Peter. The Impact of Compulsory Voting on Inequality and the Quality of the Vote. West European Politics. 40 (2017) No. 3: 621.

305 DASSONNEVILLE, Ruth; Lewis-Beck, Michael S. Rules, Institutions and the Economic Vote: Clarifying Clarity of Responsibility. West European Politics. 40 (2017) No. 3: 534

306 DE GIORGI, Elisabetta; Santana-Pereira, José. The 2015 Portuguese Legislative Election: Widening the Coalitional Space and Bringing the Extreme Left in. South European Society and Politics. 21 (2016) No. 4: 451.

307 DE HART, Betty. The Europeanization of Love: The Marriage of Convenience in European Migration Law. European Journal of Migration and Law. 19 (2017) No. 3: 281.

308 DE VILLIERS, Bertus. Power-Sharing Options in Complex Societies - Possible Lessons from South Tyrol for Young Democracies on Ways to Protect Ethnic Minorities at a Regional Level. Journal of Ethnopolitics and Minority Issues in Europe. 16 (2017) No. 1: 1.

309 DE VREESE, Claes H. How Changing Conditions Make us Reconsider the Relationship between Immigration Attitudes, Religion, and EU Attitudes. European Union Politics. 18 (2017) No. 1: 137.

310 DE VRIES, K.M. Karin. Rewriting Abdulaziz: The ECtHR Grand Chamber's Ruling in Biao v. Denmark. European Journal of Migration and Law. 18 (2016) No. 4: 467.

311 DEMPSEY, Mary Jane; NARDINI, Alia K. Identity in Today's Europe: A New Geopolitical Strategy. Journal of Contemporary European Research. 13 (2017) No. 3: $11 \mathrm{pp}$.

312 DEN HEIJER, Maarten. Remedies in the Dublin Regulation: Ghezelbash and Karim. Common Market Law Review. 54 (2017) No. 3: 859.

313 DI MASCIO, Fabrizio; Natalini, Alessandro; Stolfi, Francesco. The Implementation of Administrative Burden Reduction Policy: Mechanisms and Contexts in the Study of Europeanization. Comparative European Politics. 15 (2017) No. 2: 264.

314 DIMITRIADI, Angeliki. In Search of Asylum: Afghan Migrants in Greece. European Journal of Migration and Law. 19 (2017) No. 1: 57.

315 DONOVAN, Todd; Karp, Jeffrey. Electoral Rules, Corruption, Inequality and Evaluations of Democracy. European Journal of Political Research. 56 (2017) No. 3: 469.

316 DÖRRENBÄCHER, Nora. Europe at the Frontline: Analysing Street-Level Motivations for the Use of European Union Migration Law. Journal of European Public Policy. 24 (2017) No. 9: 1328.

317 DUNAJEVA, Jekatyerina. Those Who Count: Expert Practices of Roma Classification Book Review. Journal of Ethnopolitics and Minority Issues in Europe. 15 (2016) No. 3: 81. 
318 DUTTA, Nabamita; Williamson, Claudia R. Aiding Economic Freedom: Exploring the Role of Political Institutions. European Journal of Political Economy. (2016) No. 45 Supplement: 24 .

319 EECKHOUT, Piet; Frantziou, Eleni. Brexit and Article 50 TEU: A Constitutionalist Reading. Common Market Law Review. 54 (2017) No. 3: 695.

320 EIBL, Ferdinand; Lynge-Mangueira, Halfdan. Constraints, Competition, and Competitiveness: Explaining the Non-Linear Effect of Democratization on Political Budget Cycles. European Political Science Review. 9 (2017) No. 4: 629.

321 EISING, Rainer. Imperfect Public Goods and the Logic of Selective Exit in EU Interest Organisations. West European Politics. 40 (2017) No. 5: 1025.

322 EISING, Rainer; Rasch, Daniel; Rozbicka, Patrycja. National Interest Organisations in EU Policy-Making. West European Politics. 40 (2017) No. 5: 939.

323 EISING, Rainer; Rasch, Daniel; Rozbicka, Patrycja; Fink-Hafner, Danica; Hafner-Fink, Mitja; Novak, Meta. Who Says What to Whom? Alignments and Arguments in EU Policy-Making. West European Politics. 40 (2017) No. 5: 957.

324 EMMENEGGER, Patrick; Petersen, Klaus. Taking History Seriously in Comparative Research: The Case of Electoral System Choice, 1890-1939. Comparative European Politics. 15 (2017) No. 6: 897.

325 EPPERLY, Brad. Political Competition and De Facto Judicial Independence in Non-Democracies. European Journal of Political Research. 56 (2017) No. 2: 279.

326 EPPNER, Sebastian; Ganghof, Steffen. Institutional Veto Players and Cabinet Formation: The Veto Control Hypothesis Reconsidered. European Journal of Political Research. 56 (2017) No. 1: 169.

327 ERISEN, Cengiz; Kentmen-Cin, Cigdem. Tolerance and Perceived Threat toward Muslim Immigrants in Germany and the Netherlands. European Union Politics. 18 (2017) No. 1: 73.

328 ERISEN, Elif. Seeking Refuge in a Superordinate Group: Non-EU Immigration Heritage and European Identification. European Union Politics. 18 (2017) No. 1: 26.

329 ERZEEL, Silvia; Rashkova, Ekaterina R. Still Men's Parties? Gender and the Radical Right in Comparative Perspective. West European Politics. 40 (2017) No. 4: 812.

330 ESTRADA-TANCK, Dorothy. Undocumented Migrant Women in Europe: A Human Rights Perspective from Public International Law. Croatian Yearbook of European Law and Policy. 12 (2016): 119.

331 FAGAN, E.J.; Jones, Bryan D.; Wlezien, Christopher. Representative Systems and Policy Punctuations. Journal of European Public Policy. 24 (2017) No. 6: 809.

332 FERLAND, Benjamin. Ideological Congruence over Government Mandates under Majoritarian and Proportional Representation Electoral Systems. West European Politics. 41 (2018) No. 2: 350.

333 FERnANDES, Jorge M.; Jalali, Carlos. A Resurgent Presidency? Portuguese SemiPresidentialism and the 2016 Elections. South European Society and Politics. 22 (2017) No. 1: 121.

334 FINKE, Daniel. Bicameralism in the European Union: Parliamentary Scrutiny as a Tool for Reinforcing Party Unity. West European Politics. 40 (2017) No. 2: 275.

335 FINSERAAS, Henning; Kotsadam, Andreas. Does Personal Contact with Ethnic Minorities Affect Anti-Immigrant Sentiments? Evidence from a Field Experiment. European Journal of Political Research. 56 (2017) No. 3: 703.

336 FOA, Roberto Stefan; Ekiert, Grzegorz. The Weakness of Postcommunist Civil Society Reassessed. European Journal of Political Research. 56 (2017) No. 2: 419. 
337 FOSTER, Chase; Frieden, Jeffry. Crisis of Trust: Socio-Economic Determinants of Europeans' Confidence in Government. European Union Politics. 18 (2017) No. 4: 511.

338 FROMAGE, Diane; FASONE, Cristina. The French and the Italian Parliaments in EU Affairs Post-Lisbon: True Empowerment or Cosmetic Change? Journal of Contemporary European Research. 13 (2017) No. 3: 16 pp.

339 GARCÍA-SÁNCHEZ, Isabel-María. Does Media Freedom Improve Government Effectiveness? A Comparative Cross-Country Analysis. European Journal of Law and Economics. 42 (2016) No. 3: 515.

340 GARMANN, Sebastian. Election Frequency, Choice Fatigue, and Voter Turnout. European Journal of Political Economy. (2017) No. 47: 19.

341 GEMI, Eda. Albanian Migration in Greece: Understanding Irregularity in a Time of Crisis. European Journal of Migration and Law. 19 (2017) No. 1: 12.

342 GHERGINA, Sergiu; Volintiru, Clara. A New Model of Clientelism: Political Parties, Public Resources, and Private Contributors. European Political Science Review. 9 (2017) No. 1: 115

343 GIANNETTI, Daniela; Pedrazzani, Andrea; Pinto, Luca. Party System Change in Italy: Politicising the EU and the Rise of Eccentric Parties. South European Society and Politics. 22 (2017) No. 1: 21.

344 GOEBEL, Roger J. Adding a Little Gold to the Golden Years: Should the European Union Prohibit Compulsory Retirement as Age-Based Discrimination in Employment. Columbia Journal of European Law. 23 (2017) No. 2: 305.

345 GOOSSEnS, Elise. A Model for the Use of the European Certificate of Succession for Property Registration. European Review of Private Law. 25 (2017) No. 3: 523.

346 GRECH, Philip. Undesired Properties of the European Commission's Refugee Distribution Key. European Union Politics. 18 (2017) No. 2: 212.

347 GREENE, Zachary. Working through the Issues: How Issue Diversity and Ideological Disagreement Influence Coalition Duration. European Political Science Review. 9 (2017) No. 4: 561

348 GUERRINA, Roberta; MURPHY, Hailey. Strategic Silences in the Brexit Debate: Gender, Marginality and Governance. Journal of Contemporary European Research. 12 (2016) No. 4: 9 pp.

349 GUPTA, Sanjeev; Liu, Estelle X.; Mulas-Granados, Carlos. Now or Later? The Political Economy of Public Investment in Democracies. European Journal of Political Economy. (2016) No. 45: 101.

350 HALL, Dorota. Religion and Homosexuality in the Public Domain: Polish Debates About Reparative Therapy. European Societies. 19 (2017) No. 5: 600.

351 HALPIN, Darren R.; Fraussen, Bert. Conceptualising the Policy Engagement of Interest Groups: Involvement, Access and Prominence. European Journal of Political Research. 56 (2017) No. 3: 723.

352 HAMENSTADT, Kathrin. The Impact of the Duration of Lawful Residence on the Rights of European Union Citizens and Their Third-Country Family Members. Maastricht Journal of European and Comparative Law. 24 (2017) No. 1: 63.

353 HARRYVN, Anjo G.; Van Der Harst, Jan. Victimized by Eurosceptiscism. European Citizenship in the Dutch Political. Journal of European Integration History. 22 (2016) No. 2: 313.

354 HARTEVELD, Eelco; Kokkonen, Andrej; Dahlberg, Stefan. Adapting to Party Lines: The Effect of Party Affiliation on Attitudes to Immigration. West European Politics. 40 (2017) No. 6: 1177. 
355 HÄUSERMANN, Silja; Kurer, Thomas; Wüest, Bruno. Participation in Hard Times: How Constrained Government Depresses Turnout among the Highly Educated. West European Politics. 41 (2018) No. 2: 448.

356 HEINDLMAIER, Anita; Blauberger, Michael. Enter at Your Own Risk: Free Movement of EU Citizens in Practice. West European Politics. 40 (2017) No. 6: 1198.

357 HEINZE, Anna-Sophie. Strategies of Mainstream Parties towards their Right-Wing Populist Challengers: Denmark, Norway, Sweden and Finland in Comparison. West European Politics. 41 (2018) No. 2: 287.

358 HELANDER, Eila. European Churches and the European Parliament Elections. The Case of the Evangelical Lutheran Church of Finland. European Societies. 19 (2017) No. 5: 580 .

359 HEPPELL, Timothy; Crines, Andrew; Jeffery, David. The United Kingdom Referendum on European Union Membership: The Voting of Conservative Parliamentarians. Journal of Common Market Studies. 55 (2017) No. 4: 762.

360 HERNÁNDEZ AGUILAR, Luis Manuel. Suffering Rights and Incorporation. The German Islam Conference and the Integration of Muslims as a Discursive Means of their Racialization. European Societies. 19 (2017) No. 5: 623.

361 HOERNER, Julian M. Real Scrutiny or Smoke and Mirrors: The Determinants and Role of Resolutions of National Parliaments in European Union Affairs. European Union Politics. 18 (2017) No. 2: 307.

362 HOFER, Katharina E.; Marti, Christian; Bütler, Monika. Ready to Reform: How Popular Initiatives Can be Successful. European Journal of Political Economy. (2017) No. 48: 16 .

363 HOOGHE, Marc; Verhaegen, Soetkin. The Effect of Political Trust and Trust in European Citizens on European Identity. European Political Science Review. 9 (2017) No. 2: 161.

364 HORN, Alexander; Jensen, Carsten. When and Why Politicians Do Not Keep their Welfare Promises. European Journal of Political Research. 56 (2017) No. 2: 381.

365 HOWARD, Erica. Islamic Headscarves and the CJEU Achbita and Bougnaoui. Maastricht Journal of European and Comparative Law. 24 (2017) No. 3: 348.

366 HÜBSCHER, Evelyne. Party Governments, Clientelistic Reforms, and Varying Levels of Political Constraints. Comparative European Politics. 15 (2017) No. 6: 848.

367 HÜBSCHER, Evelyne; Sattler, Thomas. Fiscal Consolidation under Electoral Risk. European Journal of Political Research. 56 (2017) No. 1: 151.

368 HUNT, Jo; Minto, Rachel; Woolford, Jayne. Winners and Losers: The EU Referendum Vote and its Consequences for Wales. Journal of Contemporary European Research. 12 (2016) No. 4: 11 pp.

369 HURKA, Steffen; Knill, Christoph; Rivière, Léonie. Four Worlds of Morality Politics: The Impact of Institutional Venues and Party Cleavages. West European Politics. 41 (2018) No. 2: 428.

370 ISANI, Mujtaba; Schlipphak, Bernd. In the European Union we Trust: European Muslim Attitudes toward the European Union. European Union Politics. 18 (2017) No. 4: 658 .

371 IUSMEN, Ingi; Boswell, John. The Dilemmas of Pursuing 'Throughput Legitimacy' through Participatory Mechanisms. West European Politics. 40 (2017) No. 2: 459.

372 JÄCKLE, Sebastian; König, Pascal D. The Dark Side of the German 'Welcome Culture': Investigating the Causes Behind Attacks on Refugees in 2015. West European Politics. 40 (2017) No. 2: 223. 
373 JACOBS, Laura; Hooghe, Marc; de Vroome, Thomas. Television and Anti-Immigrant Sentiments: The Mediating Role of Fear of Crime and Perceived Ethnic Diversity. European Societies. 19 (2017) No. 3: 243.

374 JACQUET, Vincent. Explaining Non-Participation in Deliberative Mini-Publics. European Journal of Political Research. 56 (2017) No. 3: 640.

375 JAKOBSSON, Niklas, Kumlin, Staffan. Election Campaign Agendas, Government Partisanship, and the Welfare State. European Political Science Review. 9 (2017) No. 2: 183 .

376 JENTZSCH, Nicola. Secondary Use of Personal Data: A Welfare Analysis. European Journal of Law and Economics. 44 (2017) No. 1: 165.

377 JOPPKE, Christian. Civic Integration in Western Europe: Three Debates. West European Politics. 40 (2017) No. 6: 1153.

378 JOVIĆ-PRLAINOVIĆ, Olga; Belović, Jelena. Prohibition of Discrimination: Citizenship as a Possible Discrimination Basis. European Journal of Law Reform. 18 (2016) No. 3: 320.

379 JURADO, Ignacio; León, Sandra. Economic Crises and the Nationalisation of Politics. European Journal of Political Research. 56 (2017) No. 4: 777.

380 KAISER, Johannes; Kleinen-von-Königslöw, Katharina. The Framing of the Euro Crisis in German and Spanish Online News Media between 2010 and 2014: Does a Common European Public Discourse Emerge? Journal of Common Market Studies. 55 (2017) No. 4: 798.

381 KANTOROWICZ, Jarosław. Electoral Systems and Fiscal Policy Outcomes: Evidence from Poland. European Journal of Political Economy. (2017) No. 47: 36.

382 KARATZIA, Anastasia. The European Citizens' Initiative and the EU Institutional Balance: On Realism and the Possibilities of Affecting EU Lawmaking. Common Market Law Review. 54 (2017) No. 1: 177.

383 KARLSEN, Rune; Saglie, Jo. Party Bureaucrats, Independent Professionals, or Politicians? A Study of Party Employees. West European Politics. 40 (2017) No. 6: 1331.

384 KAUDER, Björn; Potrafke, Niklas; Reischmann, Markus. Do Politicians Reward Core Supporters? Evidence from a Discretionary Grant Program. European Journal of Political Economy. (2016) No. 45: 39.

385 KELEMEN, R. Daniel; Blauberger, Michael. Introducing the Debate: European Union Safeguards Against Member States' Democratic Backsliding. Journal of European Public Policy. 24 (2017) No. 3: 317.

386 KENTMEN-CIN, Cigdem; Erisen, Cengiz. Anti-Immigration Attitudes and the Opposition to European Integration: A Critical Assessment. European Union Politics. 18 (2017) No. 1: 3.

387 KIM, Soo Yeon; Meunier, Sophie; Nyiri, Zsolt. Yin and Yank? Public Opinion in Europe Toward the U.S. and China. Comparative European Politics. 15 (2017) No. 4: 577.

388 KJ ÆGAARD HANSEN, Kristian; Jensen, Carsten. Politized Coalitions: Social Affinity and the Politics of Redistribution. Comparative European Politics. 15 (2017) No. 2: 204.

389 KLAASSEN, Mark; Rodrigues, Peter. The Best Interests of the Child in EU Family Reunification Law: A Plea for More Guidance on the Role of Article 24(2) Charter. European Journal of Migration and Law. 19 (2017) No. 2: 191.

390 KLIPA, Ondrej. Chasing Statistical Roma: Ethnic Data Collection in Czech Primary Schools. Journal of Ethnopolitics and Minority Issues in Europe. 16 (2017) No. 1: 32. 
391 KOHLER-KOCH, Beate; Kotzian, Peter; Quittkat, Christine. The Multilevel Interest Representation of National Business Associations. West European Politics. 40 (2017) No. 5: 1046.

392 KOIVUlA, Aki; Saarinen, Arttu; Räsänen, Pekkä. Political Party Preference and Social Trust in Four Nordic Countries. Comparative European Politics. 15 (2017) No. 6: 1030.

393 KÖLLN, Ann-Kristin. Political Sophistication Affects How Citizens' Social Policy Preferences Respond to the Economy. West European Politics. 41 (2018) No. 1: 196.

394 KÖNIG, Pascal D.; Wenzelburger, Georg. Honeymoon in the Crisis: A Comparative Analysis of the Strategic Timing of Austerity Policies and their Effect on Government Popularity in Three Countries. Comparative European Politics. 15 (2017) No. 6: 991.

395 KONING, Edward Anthony. Selecting, Disentitling, or Investing? Exploring Party and Voter Responses to Immigrant Welfare Dependence in 15 West European Welfare States. Comparative European Politics. 15 (2017) No. 4: 628.

396 KOSTAKOPOULOU, Dora. What Fractures Political Unions? Failed Federations, Brexit and the Importance of Political Commitment. European Law Review. 42 (2017) No. 3: 339.

397 KRAFT, Jonas. Political Parties and Public Investments: A Comparative Analysis of 22 Western Democracies. West European Politics. 41 (2018) No. 1: 128.

398 KRIEGER, Tim; Meierrieks, Daniel. Political Capitalism: The Interaction between Income Inequality, Economic Freedom and Democracy. European Journal of Political Economy. (2016) No. 45: 115.

399 KUDRIASHOVA, Olga. Religious Associations as a National Security Threat: The Russian View in Light of European Standards. Review of Central and East European Law. 42 (2017) No. 2-3: 101.

400 KUEHN, David [et al.]. Conditions of Civilian Control in New Democracies: An Empirical Analysis of 28 'Third Wave' Democracies. European Political Science Review. 9 (2017) No. 3: 425.

401 KUTAY, Acar. How Does the European Commission Create a European Civil Society with Words? A Discourse Theoretical Inquiry. Journal of Common Market Studies. 55 (2017) No. 5: 1094.

402 KUZU, Durukan. Comparative Analysis of Political Systems and Ethnic Mobilization: Assimilation Versus Exclusion. Comparative European Politics. 15 (2017) No. 4: 557.

403 KYU KIM, Nam; Kroeger, Alex. Rewarding the Introduction of Multiparty Elections. European Journal of Political Economy. (2017) No. 49: 164.

404 LAMPRIANOU, Iasonas; Ellinas, Antonis A. Institutional Grievances and Right-Wing Extremism: Voting for Golden Dawn in Greece. South European Society and Politics. 22 (2017) No. 1: 43.

405 LANCASTER, Thomas D. The Spanish General Elections of 2015 and 2016: A New Stage in Democratic Politics? West European Politics. 40 (2017) No. 4: 919.

406 LANGER, Ana Ines; Sagarzazu, Iñaki. Bring Back the Party: Personalisation, the Media and Coalition Politics. West European Politics. 41 (2018) No. 2: 472.

407 LARCINESE, Valentino; Sircar, Indraneel. Crime and Punishment the British Way: Accountability Channels Following the MPs' Expenses Scandal. European Journal of Political Economy. (2017) No. 47: 75.

408 LESSCHAEVE, Christophe. The Predictive Power of the Left-Right Self-Placement Scale for the Policy Positions of Voters and Parties. West European Politics. 40 (2017) No. 2: 357. 
409 LEVINE, David K.; Modica, Salvatore. Size, Fungibility, and the Strength of Lobbying Organizations. European Journal of Political Economy. 49 (2017) No. 49: 71.

410 LEVY, Jonah D. The Return of the State? France's Response to the Financial and Economic Crisis. Comparative European Politics. 15 (2017) No. 4: 604.

411 LIANOS, Michalis. Religion: Opium to Amphetamine. European Societies. 19 (2017) No. 5: 517.

412 LIN, Nick C.N. [et. al.]. Gamson's Law and Voters' Perceptions of Portfolio Allocation. European Journal of Political Research. 56 (2017) No. 4: 912.

413 LINDELL, Marina [et. al.]. What Drives the Polarisation and Moderation of Opinions? Evidence from a Finnish Citizen Deliberation Experiment on Immigration. European Journal of Political Research. 56 (2017) No. 1: 23.

414 LISI, Marco. U-Turn: The Portuguese Radical Left from Marginality to Government Support. South European Society and Politics. 21 (2016) No. 4: 541.

415 LITTLE, Conor. The Irish General Election of February 2016: Towards a New Politics or an Early Election? West European Politics. 40 (2017) No. 2: 479.

416 LLOREN, Anouk; Rosset, Jan. Gendered Policy Preferences? Candidates' Views on Political Issues in a Comparative Perspective. Comparative European Politics. 15 (2017) No. 6: 944.

417 LORD, Christopher. Fragmentation, Segmentation and Centre Formation. Arena Working Papers. (2017) No. 3: 27 pp.

418 LUBBERS, Marcel; Coenders, Marcel. Nationalistic Attitudes and Voting for the Radical Right in Europe. European Union Politics. 18 (2017) No. 1: 98.

419 LUHMANN, Sybille. A Multi-Level Approach to European Identity: Does Integration Foster Identity? Journal of Common Market Studies. 55 (2017) No. 6: 1360.

420 LUHMANN, Sybille. The European Identity Survey - a Bridge between Political Science and Psychology. Journal of Contemporary European Research. 13 (2017) No. 3: $23 \mathrm{pp}$.

421 MÄKINEN, Eija. Controlling Nordic Municipalities. European Public Law. 23 (2017) No. 1: 123.

422 MARGUliES, Ben. Liberal Party Performance when Rival Parties Shift Position on the Left-Right Axis. Comparative European Politics. 14 (2016) No. 6: 802.

423 MARINOVA STEFANOVA, Boyka. Returning to Europe as Reluctant Europeans: Revisiting Trends in Public Support for the European Union in Central and Eastern Europe Twelve Years after the 2004 EU Accession. Croatian Yearbook of European Law and Policy. 12 (2016): 275.

424 MAROUFOF, Michaela. Migrating from Pakistan to Greece: Re-visiting Agency in Times of Crisis. European Journal of Migration and Law. 19 (2017) No. 1: 77.

425 MAROUFOF, Michaela. The Role of Social Networks in Georgian Migration to Greece. European Journal of Migration and Law. 19 (2017) No. 1: 34.

426 MARRERO GONZÁLEZ, Guayasén. 'Brexit': Consequences for Citizenship of the Union and Residence Rights. Maastricht Journal of European and Comparative Law. 23 (2016) No. 5: 796.

427 MARSHALL, David; Bernhagen, Patrick. Government-Business Relations in Multilevel Systems: The Effect of Conflict Perception on Venue Choice. West European Politics. 40 (2017) No. 5: 981.

428 MARTÍNEZ-ESCRIBANO, Celia. Consequences of the European Succession Regulation in European Property Law. European Review of Private Law. 25 (2017) No. 3: 553. 
429 MARTOCCHIA DIODATI, Nicola; Verzichelli, Luca. Changing Patterns of Ministerial Circulation: The Italian Case in a Long-Term Perspective. West European Politics. 40 (2017) No. 6: 1352.

430 MAVROMMATIS, George. The Rise of a Hesitant EU Host? Examining the Greek Migrant Integration Policy and its Transformation During the Crisis. Southeast European and Black Sea Studies. 17 (2017) No. 1: 1.

431 MAXWELL, D. Disputed Property Rights: Article 1 Protocol No.1 of the European Convention on Human Rights and the Land Reform (Scotland) Act 2016. European Law Review. 41 (2016) No. 6: 900.

432 MICKLER, Tim A. Who Gets What and Why? Committee Assignments in the German Bundestag. West European Politics. 41 (2018) No. 2: 517.

433 MILAČIĆ, Filip. A Painful Break or Agony Without End? The Stateness Problem and its Influence on Democratization in Croatia and Serbia. Southeast European and Black Sea Studies. 17 (2017) No. 3: 369.

434 MINKENBERG, Michael. Between Christian and Multicultural Democracy: Religious Legacies and Minority Politics. West European Politics. 41 (2018) No. 1: 53.

435 MITCHELL, Katharyne. Metrics Millennium: Social Impact Investment and the Measurement of Value. Comparative European Politics. 15 (2017) No. 5: 751.

436 MONAR, Jörg. Justice and Home Affairs. Journal of Common Market Studies. 55 (2017) No. S1: 102.

437 MORANO-FOADI, Sonia. Solidarity and Responsibility: Advancing Humanitarian Responses to EU Migratory Pressures. European Journal of Migration and Law. 19 (2017) No. 3: 223.

438 MORGADES-GIL, Silvia. The Right to Benefit from an Effective Remedy against Decisions Implying the Return of Asylum-seekers to European Safe Countries. European Journal of Migration and Law. 19 (2017) No. 3: 255.

439 MORGAN, Kimberly J. Gender, Right-Wing Populism, and Immigrant Integration Policies in France, 1989-2012. West European Politics. 40 (2017) No. 4: 887.

440 MOURY, Catherine; Standring, Adam. 'Going beyond the Troika': Power and Discourse in Portuguese Austerity Politics. European Journal of Political Research. 56 (2017) No. 3: 660.

441 MURPHY, Mary C. The EU Referendum in Northern Ireland: Closing Borders, ReOpening Border Debates. Journal of Contemporary European Research. 12 (2016) No. 4: $10 \mathrm{pp}$.

442 NAUMANN, Elias; Stoetzer, Lukas F. Immigration and Support for Redistribution: Survey Experiments in Three European Countries. West European Politics. 41 (2018) No. 1: 80.

443 NEUNDORF, Anja; Soroka, Stuart. The Origins of Redistributive Policy Preferences: Political Socialisation With and Without a Welfare State. West European Politics. 41 (2018) No. 2: 400.

444 NEUVONEN, Päivi Johanna. EU Citizenship and its 'Very Specific' Essence: Rendón Marin and CS. Common Market Law Review. 54 (2017) No. 4: 1201.

445 NICOLA, Fernanda G. Genealogies of Cost-Benefit Analysis in Transatlantic Regulatory Cooperation. Comparative European Politics. 15 (2017) No. 5: 729.

446 NICOLI, Francesco. Hard-line Euroscepticism and the Eurocrisis: Evidence from a Panel Study of 108 Elections Across Europe. Journal of Common Market Studies. 55 (2017) No. 2: 312 .

447 NICOLOSI, Salvatore Fabio. Going Unnoticed? Diagnosing the Right to Asylum in the Charter of Fundamental Rights of the European Union. European Law Journal. 23 (2017) No. 1-2: 94. 
448 NIKOLAEV, Boris; Bennett, Daniel L. Give me Liberty and Give me Control: Economic Freedom, Control Perceptions and the Paradox of Choice. European Journal of Political Economy. (2016) No. 45 Supplement: 39.

449 NIKOLOVA, Milena. Minding the Happiness Gap: Political Institutions and Perceived Quality of Life in Transition. European Journal of Political Economy. (2016) No. 45 Supplement: 129.

450 NÚÑEZ, Lidia; Simón, Pablo; Pilet, Jean-Benoit. Electoral Volatility and the Dynamics of Electoral Reform. West European Politics. 40 (2017) No. 2: 378.

451 O'BRIEN, Charlotte. The ECJ Sacrifices EU Citizenship in Vain: Commission v. United Kingdom. Common Market Law Review. 54 (2017) No. 1: 209.

452 OHMURA, Tamaki; Bailer, Stefanie; Meißner Peter; Selb, Peter. Party Animals, Career Changers and Other Pathways into Parliament. West European Politics. 41 (2018) No. 1: 169.

453 OLIVEIRA, Álvaro; King, Sarah-Jane. A Good Chess Opening: Luxembourg's First Roma Case Consolidates its Role as a Fundamental Rights Court. European Law Review. 41 (2016) No. 6: 865.

454 OLSEN, Johan P. Democratic Accountability and the Terms of Political Order. European Political Science Review. 9 (2017) No. 4: 519.

455 ONDERCO, Michal. Public Support for Coercive Diplomacy: Exploring Public Opinion Data from Ten European Countries. European Journal of Political Research. 56 (2017) No. 2: 401.

456 OND ̌́EJEK, Pavel. A Structural Approach to the Effects of Fundamental Rights on Legal Transactions in Private Law. European Constitutional Law Review. 13 (2017) No. 2: 281.

457 ORRIOLS, Lluis; Cordero, Guillermo. The Breakdown of the Spanish Two-Party System: The Upsurge of Podemos and Ciudadanos in the 2015 General Election. South European Society and Politics. 21 (2016) No. 4: 469.

458 OTJES, Simon; Katsanidou, Alexia. Beyond Kriesiland: EU Integration as a Super Issue after the Eurocrisis. European Journal of Political Research. 56 (2017) No. 2: 301.

459 OTJES, Simon; Louwerse, Tom. Parliamentary Questions as Strategic Party Tools. West European Politics. 41 (2018) No. 2: 496.

460 PANNICO, Roberto. Is the European Union Too Complicated? Citizens' Lack of Information and Party Cue Effectiveness. European Union Politics. 18 (2017) No. 3: 424.

461 PAOLI, Simone. Migration in European Integration: Themes and Debates. Journal of European Integration History. 22 (2016) No. 2: 279.

462 PARKER, Owen. Commercializing Citizenship in Crisis EU: The Case of Immigrant Investor Programmes. Journal of Common Market Studies. 55 (2017) No. 2: 332.

463 PASQUINUCCI, Daniele. The Historical Origins of Italian Euroscepticism. Journal of European Integration History. 22 (2016) No. 2: 297.

464 PATRIKIOS, Stratos; Cram, Laura. Better the Devil you Know: Threat Effects and Attachment to the European Union. Comparative European Politics. 14 (2016) No. 6: 717.

465 PAYANDEH, Mehrdad. The OMT Judgment of the German Federal Constitutional Court: Repositioning the Court within the European Constitutional Architecture. European Constitutional Law Review. 13 (2017) No. 2: 400.

466 PEARCE, Henry. Systems Thinking, Big Data, and Data Protection Law Using Ackoff's Interactive Planning to Respond to Emergent Policy Challenges. European Journal of Law Reform. 18 (2016) No. 4: 478. 
467 PÉREZ DURÁN, Ixchel; Rodríguez Menés, Jorge. Explaining Accountability for Public Policies: An fsQCA Analysis of Health Policy in Spain. European Political Science Review. 9 (2017) No. 3: 329.

468 PETROFF, Alisa. Turning Points and Transitions in the Migratory Trajectories of Skilled Romanian Immigrants in Spain. European Societies. 18 (2016) No. 5: 438.

469 PIRRO, Andrea L.P.; van Kessel, Srijn. United in Opposition? The Populist Radical Right's EU-Pessimism in Times of Crisis. Journal of European Integration. 39 (2017) No. 4: 405.

470 PLESCIA, Carolina; Staniek, Magdalena. In the Eye of the Beholder: Voters' Perceptions of Party Policy Shifts. West European Politics. 40 (2017) No. 6: 1288.

471 POULOU, Anastasia. Financial Assistance Conditionality and Human Rights Protection: What is the Role of the EU Charter of Fundamental Rights? Common Market Law Review. 54 (2017) No. 4: 991.

472 PRITONI, Andrea. Decision-Making Potential and 'Detailed' Legislation of Western European Parliamentary Governments (1990-2013). Comparative European Politics. 15 (2017) No. 2: 157.

473 RAITIO, Juha; Raulus, Helena. The UK EU Referendum and the Move towards Brexit. Maastricht Journal of European and Comparative Law. 24 (2017) No. 1: 25.

474 RASHKOVA, Ekaterina R.; Zankina, Emilia. Are (Populist) Radical Right Parties Männerparteien? Evidence from Bulgaria. West European Politics. 40 (2017) No. 4: 848.

475 RATTO TRABUCCO, Fabio. Local Self-Government Development in Lithuania. European Public Law. 23 (2017) No. 2: 253.

476 RIERA, Pedro; Bol, Damien. Ticket-Splitting in Mixed-Member Systems: On the Importance of Seat Linkage between Electoral Tiers. West European Politics. 40 (2017) No. 3: 584.

477 ROBERTS, Kenneth M. State of the Field. European Journal of Political Research. 56 (2017) No. 2: 218.

478 RODRÍGUEZ-TERUEL, Juan; Barrio, Astrid. Going National: Ciudadanos from Catalonia to Spain. South European Society and Politics. 21 (2016) No. 4: 587.

479 RODRÍGUEZ-TERUEL, Juan; Barrio, Astrid; Barberà, Oscar. Fast and Furious: Podemos' Quest for Power in Multi-level Spain. South European Society and Politics. 21 (2016) No. 4: 561.

480 ROODUIJN, Matthijs [et. al.]. Radical Distinction: Support for Radical Left and Radical Right Parties in Europe. European Union Politics. 18 (2017) No. 4: 536.

481 RUIZ-RUFINO, Rubén; Alonso, Sonia. Democracy without Choice: Citizens' Perceptions of Government Autonomy During the Eurozone Crisis. European Journal of Political Research. 56 (2017) No. 2: 320.

482 SCHÄRDEL, Julian; König, Pascal. Professors, Comedians and Billionaires: An Empirical Analysis of Newspaper Coverage of New Eurosceptic Parties in Three 2013 National Elections. Comparative European Politics. 15 (2017) No. 2: 310.

483 SCHNABEL, Annette; Behrens, Kathrin; Grötsch, Florian. Religion in European Constitutions - Cases of Different Secularities. European Societies. 19 (2017) No. 5: 551

484 SCHNYDER, Melissa. The Structure of Diversity among Migrant Rights Organisations in Europe: Implications for Supranational Political Participation. Journal of Contemporary European Research. 12 (2016) No. 4: 16 pp.

485 SCHUMACHER, Gijs; Elmelund-Præstekær, Christian. Party Performance Explains Disagreement between Politicians and their Parties. West European Politics. 41 (2018) No. 2: 329. 
486 SEBESTA, Lorenzo. Italy's Choice of Europe and the Challenges of Modernization. Journal of European Integration History. 22 (2016) No. 2: 355.

487 SEDELMEIER, Ulrich. Political Safeguards Against Democratic Backsliding in the EU: The Limits of Material Sanctions and the Scope of Social Pressure. Journal of European Public Policy. 24 (2017) No. 3: 337.

488 SEEBERG, Henrik Bech. What Can a Government Do? Government Issue Ownership and Real-World Problems. European Journal of Political Research. 56 (2017) No. 2: 346.

489 SENNINGER, Roman. Issue Expansion and Selective Scrutiny - How Opposition Parties Used Parliamentary Questions about the European Union in the National Arena from 1973 to 2013. European Union Politics. 18 (2017) No. 2: 283.

490 SERUP CHRISTENSEN, Henrik. All the Same? Examining the Link Between Three Kinds of Political Dissatisfaction and Protest. Comparative European Politics. 14 (2016) No. 6: 781 .

491 SETÄLÄ, Maija. Connecting Deliberative Mini-Publics to Representative Decision Making. European Journal of Political Research. 56 (2017) No. 4: 846.

492 SÉVILLE, Astrid, From 'One Right Way' to 'One Ruinous Way'? Discursive Shifts in 'There is No Alternative'. European Political Science Review. 9 (2017) No. 3: 449.

493 SHAW, Jo. The Quintessentially Democratic Act? Democracy, Political Community and Citizenship In and After the UK's EU Referendum of June 2016. Journal of European Integration. 39 (2017) No. 5: 559.

494 SHEIKHZADEGAN, Amir; Nollert, Michael. Religion, the Public Sphere, and Identity Politics: How a Radical Muslim Organization Defies the Populist Right in Switzerland. European Societies. 19 (2017) No. 5: 645.

495 SIEBERER, Ulrich; Müller, Wolfgang C. Aiming higher: The Consequences of Progressive Ambition among MPs in European Parliaments. European Political Science Review. 9 (2017) No. 1: 27.

496 SIMÓN, Pablo. The Challenges of the New Spanish Multipartism: Government Formation Failure and the 2016 General Election. South European Society and Politics. 21 (2016) No. 4: 493.

497 SIMÓN, Pablo; Verge, Tània. Gender Quotas and Political Representation in Spain and Portugal: Electoral Competition, Learning and Emulation. South European Society and Politics. 22 (2017) No. 2: 179.

498 SINDBJERG MARTINSEN, Dorte; Pons Rotger, Gabriel. The Fiscal Impact of EU Immigration on the Tax-Financed Welfare State: Testing the 'Welfare Burden' Thesis. European Union Politics. 18 (2017) No. 4: 620.

499 SITAROPOULOS, Nikolaos. Migrant Ill-Treatment in Greek Law Enforcement-are the Strasbourg Court Judgments the Tip of the Iceberg? European Journal of Migration and Law. 19 (2017) No. 2: 136.

500 SNELL, Jukka. Why Does the EU Keep Losing in Referenda, and What to Do About It? European Law Review. 41 (2016) No. 6: 779.

501 SOARES, Anthony. Living Within and Outside Unions: The Consequences of Brexit for Northern Ireland. Journal of Contemporary European Research. 12 (2016) No. 4: $9 \mathrm{pp}$.

502 SÖDERLUND, Peter. Candidate-Centred Electoral Systems and Voter Turnout. West European Politics. 40 (2017) No. 3: 516.

503 SÖLTER, Nicolas. The Abyss of Complexity: Some Remarks on European and German Law in the Migration Crisis. European Public Law. 23 (2017) No. 1: 41.

504 SPANO, Robert. The EFTA Court and Fundamental Rights. European Constitutional Law Review. 13 (2017) No. 3: 475. 
505 SPIERINGS, Niels; Zaslove, Andrej. Gender, Populist Attitudes, and Voting: Explaining the Gender Gap in Voting for Populist Radical Right and Populist Radical Left Parties. West European Politics. 40 (2017) No. 4: 821.

506 SPOON, Jae-Jae; Klüver, Heike. Does Anybody Notice? How Policy Positions of Coalition Parties are Perceived by Voters. European Journal of Political Research. 56 (2017) No. 1: 115.

507 STEembergen, Marco R.; Siczek, Tomasz. Better the Devil You Know? RiskTaking, Globalization and Populism in Great Britain. European Union Politics. 18 (2017) No. 1: 119.

508 STEENVOORDEN, Eefje; Harteveld, Eelco. The Appeal of Nostalgia: The Influence of Societal Pessimism on Support for Populist Radical Right Parties. West European Politics. 41 (2018) No. 1: 28.

509 STRAZZARI, Davide. Linguistic Integration Test and Federalism: A Comparative Analysis. European Journal of Migration and Law. 18 (2016) No. 4: 442.

510 SWIDER, Katja; den Heijer, Maarten. Why Union Law Can and Should Protect Stateless Persons. European Journal of Migration and Law. 19 (2017) No. 2: 101.

511 SZENT-IVÁNY, Balázs; Lightfoot, Simon. Determinants of Civil Society Influence: The Case of International Development and Humanitarian NGOs in the Czech Republic and Hungary. Comparative European Politics. 14 (2016) No. 6: 761.

512 ŠKRINJAR VIDOVIĆ, Marina. EU Data Protection Reform: Challenges for Cloud Computing. Croatian Yearbook of European Law and Policy. 12 (2016): 171.

513 TAKE, Ingo. The Hanseatic League as an Early Example of Cross-Border Governance? Journal of European Integration History. 23 (2017) No. 1: 71.

514 TALVING, Lisa. The Electoral Consequences of Austerity: Economic Policy Voting in Europe in Times of Crisis. West European Politics. 40 (2017) No. 3: 560.

515 TARNOK, Balazs. European Minorities Win a Battle in Luxembourg - The Judgment of the General Court in the Case Minority SafePack European Citizens' Initiative. Journal of Ethnopolitics and Minority Issues in Europe. 16 (2017) No. 1: 79.

516 THEUNS, Tom. Promoting Democracy Through Economic Conditionality in the ENP: A Normative Critique. Journal of European Integration. 39 (2017) No. 3: 287.

517 THYM, Daniel. The 'Refugee Crisis' as a Challenge of Legal Design and Institutional Legitimacy. Common Market Law Review. 53 (2016) No. 6: 1545.

518 TORTOLA, Pier Domenico. Clarifying Multilevel Governance. European Journal of Political Research. 56 (2017) No. 2: 234.

519 TRIANDAFYLLIDOU, Anna. Beyond Irregular Migration Governance: Zooming in on Migrants' Agency. European Journal of Migration and Law. 19 (2017) No. 1: 1.

520 TRONDAL, Jarle; Bauer, Michael W. Conceptualizing the European Multilevel Administrative Order: Capturing Variation in the European Administrative System. European Political Science Review. 9 (2017) No. 1: 73.

521 TSAKATIKA, Myrto. SYRIZA's Electoral Rise in Greece: Protest, Trust and the Art of Political Manipulation. South European Society and Politics. 21 (2016) No. 4: 519.

522 TSATSANIS, Emmanouil; Teperoglou, Eftichia. Realignment under Stress: The July 2015 Referendum and the September Parliamentary Election in Greece. South European Society and Politics. 21 (2016) No. 4: 427.

523 TSIRBAS, Yannis. The January 2015 Parliamentary Election in Greece: Government Change, Partial Punishment and Hesitant Stabilisation. South European Society and Politics. 21 (2016) No. 4: 407.

524 TURGEON, Mathieu; Bélanger, Éric. Institutions and Attribution of Responsibility Outside the Electoral Context: A Look at French Semi-Presidentialism. European Political Science Review. 9 (2017) No. 2: 209. 
525 TZELGOV, Eitan. Coalition Oversight and Blame Avoidance in Greece. European Political Science Review. 9 (2017) No. 1: 95.

526 VAN BOCKEL, Bas. The Single Supervisory Mechanism Regulation: Questions of Ne Bis in Idem and Implications for the Further Integration of the System of Fundamental Rights Protection in the EU. Maastricht Journal of European and Comparative Law. 24 (2017) No. 2: 194.

527 VAN DE WARDT, Marc; Berkhout, Joost; Vermeulen, Floris. Ecologies of Ideologies: Explaining Party Entry and Exit in West-European Parliaments, 1945-2013. European Union Politics. 18 (2017) No. 2: 239.

528 VAN DER JEUGHT, S. The Protection of Linguistic Minorities in Italy: A Clean Break with the Past. Journal of Ethnopolitics and Minority Issues in Europe. 15 (2016) No. 3: 57.

529 VAN NIMWEGEN, Stephan. The Need for the Netherlands and Belgium to Further Integrate Police Cooperation. An Example for Europe? New Journal of European Criminal Law. 8 (2017) No. 3: 323.

530 VAN SETTEN, Menno; Scheepers, Peer; Lubbers, Marcel. Support for Restrictive Immigration Policies in the European Union 2002-2013: The Impact of Economic Strain and Ethnic Threat for Vulnerable Economic Groups. European Societies. 19 (2017) No. 4: 440.

531 VAN SPANJE, Joost; Dirk de Graaf, Nan. How Established Parties Reduce Other Parties' Electoral Support: The Strategy of Parroting the Pariah. West European Politics. 41 (2018) No. 1: 1

532 VAN WOLLEGHEM, Pierre Georges. Why Implement without a Tangible Threat? The Effect of a Soft Instrument on National Migrant Integration Policies. Journal of Common Market Studies. 55 (2017) No. 5: 1127.

533 VASILOPOULOS, Pavlos. Terrorist Events, Emotional Reactions, and Political Participation: The 2015 Paris Attacks. West European Politics. 41 (2018) No. 1: 102.

534 VERSCHUEREN, Herwig. Employment and Social Security Rights of Third-Country Labour Migrants under EU Law: An Incomplete Patchwork of Legal Protection. European Journal of Migration and Law. 18 (2016) No. 4: 373.

535 VIDAL, Guillem. Challenging Business as Usual? The Rise of New Parties in Spain in Times of Crisis. West European Politics. 41 (2018) No. 2: 261.

536 VLASE, Ionela; Preotasa, Ana Maria. Romanians' Current Perception of Threat from Immigrants in a Context of Co-ethnic Migration: Assessing the Role of Intergroup Conflict and Active/Passive Contact. Southeast European and Black Sea Studies. 17 (2017) No. 3: 421

537 VOGIATZIS, Nikos. Between Discretion and Control: Reflections on the Institutional Position of the Commission within the European Citizens' Initiative Process. European Law Journal. 23 (2017) No. 3-4: 250.

538 VOICU, Bogdan, Tufiș, Claudiu D. Migrating Trust: Contextual Determinants of International Migrants' Confidence in Political Institutions. European Political Science Review. 9 (2017) No. 3: 351.

539 VON BAHR, Johanna. Explaining Child Rights Mainstreaming in EU External Policy. Comparative European Politics. 15 (2017) No. 4: 499.

540 WALTER, Stefanie. Explaining the Visibility of EU Citizens: A Multi-Level Analysis of European Union News. European Political Science Review. 9 (2017) No. 2: 233.

541 WALTERS, William. Live Governance, Borders, and the Time-Space of the Situation: EUROSUR and the Genealogy of Bordering in Europe. Comparative European Politics. 15 (2017) No. 5: 794. 
542 WARREN, Thomas; Holden, Patrick; Howell, Kerry E. The European Commission and Fiscal Governance Reform: A Strategic Actor? West European Politics. 40 (2017) No. 6: 1310 .

543 WENZELBURGER, Georg; Staff, Helge. The 'Third Way' and the Politics of Law and Order: Explaining Differences in Law and Order Policies between Blair's New Labour and Schröder's SPD. European Journal of Political Research. 56 (2017) No. 3: 553.

544 WILlUMSEN, David M.; Öhberg, Patrik. Toe the Line, Break the Whip: Explaining Floor Dissent in Parliamentary Democracies. West European Politics. 40 (2017) No. 4: 688 .

545 WILSON, Erin K. The Socio-Political Dynamics of Secularism and Epistemological Injustice in Global Justice Theory and Practice. European Societies. 19 (2017) No. 5: 529 .

546 WINKEL, Hiedemarie; Ganiel, Gladys. The Social Dynamics of Religion in the Public Domain. European Societies. 19 (2017) No. 5: 520.

547 WONG, Mathew Y.H. Median Voter and Power Resources Revisited: A Composite Model of Inequality. European Political Science Review. 9 (2017) No. 4: 607.

548 WONKA, Arndt. German MPs and Interest Groups in EU Multilevel Policy-Making: The Politics of Information Exchange. West European Politics. 40 (2017) No. 5: 1004.

549 WOOD, James D. G. The Effects of the Distribution of Mortgage Credit on the Wage Share: Varieties of Residential Capitalism Compared. Comparative European Politics. 15 (2017) No. 6: 819.

04 The Budget - Financing the European Union

(Fraud / Mismanagement / OLAF)

550 BEnEDETTO, Giacomo. Power, Money and Reversion Points: The European Union's Annual Budgets Since 2010. Journal of European Public Policy. 24 (2017) No. 5: 633.

551 CORDERO, Guillermo; Blais, André. Is a Corrupt Government Totally Unacceptable? West European Politics. 40 (2017) No. 4: 645.

552 CROWE, Richard. The European Budgetary Galaxy. European Constitutional Law Review. 13 (2017) No. 3: 428.

553 CROWE, Richard. The European Council and the Multiannual Financial Framework. Cambridge Yearbook of European Legal Studies. 18 (2016): 45.

554 CSÚRI, András. The Proposed European Public Prosecutor's Office - from a Trojan Horse to a White Elephant? Cambridge Yearbook of European Legal Studies. 18 (2016): 122 .

555 DORAY-DEMERS, Pascal; Foucault, Martial. The Politics of Fiscal Rules within the European Union: A Dynamic Analysis of Fiscal Rules Stringency. Journal of European Public Policy. 24 (2017) No. 6: 852.

556 GANDRUD, Christopher; Hallerberg, Mark. Interpreting Fiscal Accounting Rules in the European Union. Journal of European Public Policy. 24 (2017) No. 6: 832.

557 KRENN, Christoph. The European Court of Justice's Financial Accountability: How the European Parliament Incites and Monitors Judicial Reform through the Budgetary Process. European Constitutional Law Review. 13 (2017) No. 3: 453.

558 LIPSMEYER, Christine S.; Philips, Andrew Q.; Whitten, Guy D. The Effects of Immigration and Integration on European Budgetary Trade-Offs. Journal of European Public Policy. 24 (2017) No. 6: 912. 
559 SINDBJERG MARTINSEN, Dorte; Pons Rotger, Gabriel. The Fiscal Impact of EU Immigration on the Tax-Financed Welfare State: Testing the 'Welfare Burden' Thesis. European Union Politics. 18 (2017) No. 4: 620.

05 Economic and monetary policy

(Growth, competitiveness and employment / Economic and Monetary Union / Euro / Budgetary discipline / Fiscal surveillance / European Central Bank)

560 AVBELJ, Matej. The European Central Bank in National Criminal Proceedings. European Law Review. 42 (2017) No. 4: 474.

561 BALLABRIGA, Fernando; Villegas-Sánchez, Carolina. Specialization, Risk Sharing and the Euro. Journal of Common Market Studies. 55 (2017) No. 6: 1380.

562 BECKMANN, Joscha; Czudaj, Robert. Exchange Rate Expectations and Economic Policy Uncertainty. European Journal of Political Economy. (2017) No. 47: 148.

563 BELKE, Ansgar; Klose, Jens. Equilibrium Real Interest Rates and Secular Stagnation: An Empirical Analysis for Euro Area Member Countries. Journal of Common Market Studies. 55 (2017) No. 6: 1221.

564 BENCZES, István; Szent-Iványi, Balázs. The European Economy: The Recovery Continues, but for How Long? Journal of Common Market Studies. 55 (2017) No. S1: 133.

565 Bentivoglio, Giulia. The Tentative Alliance? Britain, Italy and Participation in the European Monetary System. Journal of European Integration History. 22 (2016) No. 1: 85.

566 BJØRNSKOV, Christian. Economic Freedom and Economic Crises. European Journal of Political Economy. (2016) No. 45 Supplement: 11.

567 BÖRZEL, Tanja A.; Risse, Thomas. From the Euro to the Schengen Crises: European Integration Theories, Politicization, and Identity Politics. Journal of European Public Policy. 25 (2018) No. 1: 83.

568 CANOFARI, Paolo; Di Bartolomeo, Giovanni. Regime Switches Under Policy Uncertainty in Monetary Unions. European Journal of Political Economy. (2017) No. 47: 124.

569 CHORTAREAS, Georgioe; Mavrodimitrakis, Christos. Strategic Fiscal Policies and Leadership in a Monetary Union. European Journal of Political Economy. 47 (2017) No. 47: 133.

570 CRAIG, Paul. The Eurogroup, Power and Accountability. European Law Journal. 23 (2017) No. 3-4: 234.

571 CURTIN, Deirdre. 'Accountable Independence' of the European Central Bank: Seeing the Logics of Transparency. European Law Journal. 23 (2017) No. 1-2: 28.

572 DANZMANN, Max. Final Deposition of Losses Through the European Central Bank's Balance Sheet. European Public Law. 23 (2017) No. 2: 365.

573 DOMURATH, Irina. Mortgage Debt and the Social Function of Contract. European Law Journal. 22 (2016) No. 6: 758.

574 DUTTA, Nabamita; Williamson, Claudia R. Aiding Economic Freedom: Exploring the Role of Political Institutions. European Journal of Political Economy. (2016) No. 45 Supplement: 24.

575 ERIKSEN, Erik O. Structural Injustice and Solidarity. The Case of the Eurozone Crisis. Arena Working Papers. (2017) No. 4: 31 pp.

576 FERRERA, Maurizio. The Stein Rokkan Lecture 2016 Mission Impossible? Reconciling Economic and Social Europe after the Euro Crisis and Brexit. European Journal of Political Research. 56 (2017) No. 1: 3. 
577 FRERICHS, Sabine. Unravelling the European Community of Debt. European Law Journal. 22 (2016) No. 6: 720.

578 GEORGAKOPOUlOS, Nicholas L. PIRG Doldrums: Exit Via Overrecapitalization. European Journal of Law and Economics. 43 (2017) No. 2: 317.

579 GLÖCKLER, Gabriel; Lindner, Johannes, Salines, Marion. Explaining the Sudden Creation of a Banking Supervisor for the Euro Area. Journal of European Public Policy. 24 (2017) No. 8: 1135.

580 GOLDBACH, Roman. Quo Vadis? Global Finance and the EU After the Financial Crisis. Journal of European Integration. 39 (2017) No. 6: 755.

581 GONTHIER, Frederic. Parallel Publics? Support for Income Redistribution in Times of Economic Crisis. European Journal of Political Research. 56 (2017) No. 1: 92.

582 GREN, Jakub. The Politics of Delegation in European Banking Union: Building the ECB Supervisory Oversight Capacity. Journal of Contemporary European Research. 13 (2017) No. 2: 16 pp.

583 GRUND, Sebastian. The European Central Bank's Public Sector Purchase Programme (PSPP), the Prohibition of Monetary Financing and Sovereign Debt Restructuring Scenarios. European Law Review. 41 (2016) No. 6: 781.

584 GRUND, Sebastian. The Legal Consequences of Sovereign Insolvency - a Review of Creditor Litigation in Germany Following the Greek Debt Restructuring. Maastricht Journal of European and Comparative Law. 24 (2017) No. 3: 399.

585 GUPTA, Sanjeev; Liu; Estelle X.; Mulas-Granados, Carlos. Now or Later? The Political Economy of Public Investment in Democracies. European Journal of Political Economy. (2016) No. 45: 101.

586 HALL, Peter A. Varieties of Capitalism in Light of the Euro Crisis. Journal of European Public Policy. 25 (2018) No. 1: 7.

587 HEIDEBRECHT, Sebastian. Trying Not to be Caught in the Act: Explaining European Central Bank's Bounded Role in Shaping the European Banking Union. Journal of Contemporary European Research. 13 (2017) No. 2: 19 pp.

588 HENNESSY, Alexandra. Good Samaritans vs. Hardliners: The Role of Credible Signalling in Greek Bailout Negotiations. Journal of Common Market Studies. 55 (2017) No. 4: 744.

589 HERWARTZ, Helmut; Theilen, Bernd. Ideology and Redistribution through Public Spending. European Journal of Political Economy. (2017) No. 46: 74.

590 HODSON, Dermot. Eurozone Governance in 2016: The Italian Banking Crisis, Fiscal Flexibility and Brexit (Plus Plus Plus). Journal of Common Market Studies. 55 (2017) No. S1: 118.

591 HOOGHE, Liesbet; Marks, Gary. Cleavage Theory Meets Europe's Crises: Lipset, Rokkan, and the Transnational Cleavage. Journal of European Public Policy. 25 (2018) No. 1: 109.

592 JUUTILAINEN, Teemu. Law-Based Commodification of Private Debt. European Law Journal. 22 (2016) No. 6: 743.

593 KAISER, Johannes; Kleinen-von-Königslöw, Katharina. The Framing of the Euro Crisis in German and Spanish Online News Media between 2010 and 2014: Does a Common European Public Discourse Emerge? Journal of Common Market Studies. 55 (2017) No. 4: 798.

594 KERN, Alexander. The European Central Bank and Banking Supervision: The Regulatory Limits of the Single Supervisory Mechanism. European Company and Financial Law Review. 13 (2016) No. 3: 467. 
595 KÖNIG, Pascal D.; Wenzelburger, Georg. Honeymoon in the Crisis: A Comparative Analysis of the Strategic Timing of Austerity Policies and their Effect on Government Popularity in Three Countries. Comparative European Politics. 15 (2017) No. 6: 991.

596 KOUTRAKOS, Panos. Brexit and European Economic Area membership. European Law Review. 42 (2017) No. 5: 617.

597 KRIESI, Hanspeter. The Implications of the Euro Crisis for Democracy. Journal of European Public Policy. 25 (2018) No. 1: 59.

598 LAMANDINI, Marco; Ramos, David; Solana, Javier. The European Central Bank (ECB) as a Catalyst for Change in EU Law, Part 1: The ECB's Mandate. Columbia Journal of European Law. 23 (2016) No. 1: 1.

599 LAMANDINI, Marco; Ramos, David; Solana, Javier. The European Central Bank (ECB) Powers as a Catalyst for Change in EU Law, Part 2: SSM, SRM, and Fundamental Rights. Columbia Journal of European Law. 23 (2017) No. 2: 199.

600 LEINO, Päivi; Saarenheimo, Tuomas. Sovereignty and Subordination: On the Limits of EU Economic Policy Coordination. European Law Review. 42 (2017) No. 2: 166.

601 LO SCHIAVO, Gianni. Conditions and Obligations in ECB Supervisory Decisions as Ancillary Provisions under SSM Law. European Company and Financial Law Review. 14 (2017) No. 1: 94.

602 LOSADA, Fernando. Institutional Implications of the Rise of a Debt-Based Monetary Regime in Europe. European Law Journal. 22 (2016) No. 6: 822.

603 LOVERING, Ian Alexander. Bruised but Not Beaten: The Persistence of Austerity in Europe. Journal of European Integration. 39 (2017) No. 6: 707.

604 ŁYZIAK, Tomasz; Paloviita, Maritta. Anchoring of Inflation Expectations in the Euro Area: Recent Evidence Based on Survey Dana. European Journal of Political Economy. (2017) No. 46: 52 .

605 MARTIN, Antoine; Mercurio, Bryan. The IMF and Its Shifting Mandate towards Capital Movements and Capital Controls: A Legal Perspective. Legal Issues of Economic Integration. 44 (2017) No. 3: 211.

606 MEGLIANI, Mauro. Restructuring Greek Debt: Alternative Routes. Legal Issues of Economic Integration. 44 (2017) No. 2: 111.

607 MENÉnDEZ, Agustín José. Democracy, Translucidity and Accountability: The Eurozone vs. The Democratic Right to Know. European Law Journal. 23 (2017) No. 1-2: 2.

608 NIKOLAEV, Boris; Bennett, Daniel L. Give me Liberty and Give me Control: Economic Freedom, Control Perceptions and the Paradox of Choice. European Journal of Political Economy. (2016) No. 45 Supplement: 39.

609 O'GORMAN, Roderic. The Failure of the Troika to Measure the Impact of the Economic Adjustment Programmes on the Vulnerable. Legal Issues of Economic Integration. 44 (2017) No. 3: 265.

610 OTERO-IGLESIAS, Miguel. Still Waiting for Paris: Germany's Reluctant Hegemony in Pursuing Political Union in the Euro Area. Journal of European Integration. 39 (2017) No. 3: 349.

611 OTERO-IGLESIAS, Miguel; Steinberg, Federico. Following the Franco-German Harbinger? The Footprint of the Euro in Regional Monetary Integration. Comparative European Politics. 15 (2017) No. 2: 220.

612 OTRACHSHENKO, Vladimir; Popova, Olga; Tavares, José. Psychological Costs of Currency Transition: Evidence from the Euro Adoption. European Journal of Political Economy. (2016) No. 45: 89. 
613 PITSOULIS, Anthanassios; Schwuchow, Soeren C. Holding out for a Better Deal: Brinkmanship in the Greek Bailout Negotiations. European Journal of Political Economy. (2017) No. 48: 40.

614 PONTUSSON, Jonas; Weisstanner, David. Macroeconomic Conditions, Inequality Shocks and the Politics of Redistribution, 1990-2013. Journal of European Public Policy. 25 (2018) No. 1: 31.

615 POULOU, Anastasia. The Liability of the EU in the ESM Framework Case Note. Maastricht Journal of European and Comparative Law. 24 (2017) No. 1: 127.

616 REGAN, Aidan. The Imbalance of Capitalisms in the Eurozone: Can the North and South of Europe Converge? Comparative European Politics. 15 (2017) No. 6: 969.

617 REPASI, René. Judicial Protection Against Austerity Measures in the Euro Area: Ledra and Mallis. Common Market Law Review. 54 (2017) No. 4: 1123.

618 RUND, Sebastian; Grle, Filip. The European Central Bank's Public Sector Purchase Programme (PSPP), the Prohibition of Monetary Financing and Sovereign Debt Restructuring Scenarios. European Law Review. 41 (2016) No. 6: 781.

619 SALMON, Keith. A Decade of Lost Growth: Economic Policy in Spain through the Great Recession. South European Society and Politics. 22 (2017) No. 2: 239.

620 SCHAMMO, Pierre. The European Central Bank's Duty of Care for the Unity and Integrity of the Internal Market. European Law Review. 42 (2017) No. 1: 3.

621 SCHOELleR, Magnus G. Providing Political Leadership? Three Case Studies on Germany's Ambiguous Role in the Eurozone Crisis. Journal of European Public Policy. 24 (2017) No. 1: 1.

622 STEINBACH, Armin. All's Well That Ends Well: Crisis Policy after the German Constitutional Court's Ruling in Gauweiler (Case Note). Maastricht Journal of European and Comparative Law. 24 (2017) No. 1: 140.

623 STEINBACH, Armin. Effect-Based Analysis in the Court's Jurisprudence on the Euro Crisis. European Law Review. 42 (2017) No. 2: 254.

624 TUORI, Klaus. Has Euro Area Monetary Policy Become Redistribution by Monetary Means? 'Unconventional' Monetary Policy as a Hidden Transfer Mechanism. European Law Journal. 22 (2016) No. 6: 838.

625 UNGERER, Johannes; Ziaka, Lamprini. Reflections on the Greek Capital Controls: How the Rescue of the National Economy Justifies Restricting Private Business. Legal Issues of Economic Integration. 44 (2017) No. 2: 135.

626 VAN DEN BERGH, Roger. Farewell Utopia? Why the European Union Should Take the Economics of Federalism Seriously. Maastricht Journal of European and Comparative Law. 23 (2016) No. 6: 937.

627 VERDUN, Amy. Political Leadership of the European Central Bank. Journal of European Integration. 39 (2017) No. 2: 207.

628 ZAHARIADIS, Nikolaos. Bargaining Power and Negotiation Strategy: Examining the Greek Bailouts, 2010-2015. Journal of European Public Policy. 24 (2017) No. 5: 675.

06 Single market - Competition

(Antitrust policy / State aids / Merger policy / Free movement of goods / Free movement of services / Freedom of establishment / Free movement of capital / Intellectual property / Company law / Tax issues / Free movement of people)

629 ABDALLA JARADT, Nashat Mahmoud. Corporate Social Responsibility: A Comparative Study in Legal Perspectives. European Business Law Review. 28 (2017) No. 3: 391. 
630 ABU KARKY, Hetham Hani. International Support to Competition Advocacy in Jordan. European Competition Law Review. 38 (2017) No. 4: 187.

631 AHERN, Deirdre. Turning Up the Heat? EU Sustainability Goals and the Role of Reporting under the Non-Financial Reporting Directive. European Company and Financial Law Review. 13 (2016) No. 4: 599.

632 AHMED, Masood. Judicial Approaches to the IBA Guidelines on Conflicts of Interest in International Arbitration. European Business Law Review. 28 (2017) No. 5: 649 .

633 AHMED, Mukarrum. BREXIT and English Jurisdiction Agreements: The PostReferendum Legal Landscape. European Business Law Review. 27 (2016) No. 7: 989.

634 AHMED, Mukarrum. The Legal Regulation and Enforcement of Asymmetric Jurisdiction Agreements in the European Union. European Business Law Review. 28 (2017) No. 3: 403.

635 AIKENS, Richard; Dinsmore, Andrew. Jurisdiction, Enforcement and the Conflict of Laws in Cross-Border Commercial Disputes: What Are the Legal Consequences of Brexit? European Business Law Review. 27 (2016) No. 7: 903.

636 ALBERTI, Jacopo. New Developments in the EU System of Judicial Protection: The Creation of the Unified Patent Court and Its Future Relations with the CJEU. Maastricht Journal of European and Comparative Law. 24 (2017) No. 1: 6.

637 ALIJA, Nevin. State Aid for Green Electricity Case Law Annotations. European State Aid Law Quarterly. 15 (2016) No. 3: 452.

638 ALLOTTI, Valentina. Mediation and Corporate Disputes: An Opportunity. European Company Law. 14 (2017) No. 2: 50.

639 ALPA, Guido. European Private Law, Conceptions and Definitions of Contract. European Business Law Review. 27 (2016) No. 6: 709.

640 AMAND, Christian. EU Value Added Tax: The Directive on Vouchers in the Light of the General Value Added Tax Rules. Intertax. 45 (2017) No. 2: 150.

641 AMBRUZ, Vladimír. The Rule in Saunders v. Vautier and the Czech Trust Law. European Review of Private Law. 24 (2016) No. 6: 1011.

642 ANDENAS, Mads; Della Negra, Federico. Between Contract Law and Financial Regulation: Towards the Europeanisation of General Contract Law. European Business Law Review. 28 (2017) No. 4: 499.

643 ANDERSSON, Krister. Taxation of the Digital Economy. Intertax. 45 (2017) No. 10: 590.

644 ANDREANGELI, Arianna. Competition Law and Fundamental Rights. Journal of European Competition Law and Practice. 8 (2017) No. 8: 524.

645 ANDREANGELI, Arianna. The Consequences of Brexit for Competition Litigation: An End to a 'Success Story'? European Competition Law Review. 38 (2017) No. 5: 228.

646 ANDRIANESIS, Anastasios P. The Opening of Multijurisdictional Insolvencies Through the Prism of the Recast Regulation 848/2015. European Company Law. 14 (2017) No. 1: 6.

647 ANSTEY, George; Christian, Soren. When Sisyphus Gave up: Capacity Markets and State Aid in the EU Energy and State Aid Control. European State Aid Law Quarterly. 16 (2017) No. 1: 46.

648 APOSTOLAKIS, Ioannis. Antitrust Liability in Cases of Indirect Contacts Between Competitors: VM Remonts. Common Market Law Review. 54 (2017) No. 2: 605.

649 ARENA, Amedeo. Exercise of EU Competences and Pre-emption of Member States' Powers in the Internal and the External Sphere: Towards 'Grand Unification'? Yearbook of European Law. 35 (2016) No. 1: 28. 
650 ARGENTATI, Anna. Antitrust Scrutiny over Regulations: Results and Effectiveness in the Italian Experience. European Competition Law Review. 38 (2017) No. 1: 23.

651 ASCHAUER, Christian; Fremuth-Wolf, Alice. Mediation of Corporate Disputes in Austria. European Company Law. 14 (2017) No. 2: 54.

652 ATHANASAKI, Vasiliki. State Aid Rules in the Financial Sector During the Economic Crisis: A Disguised but yet Necessary Retreat or an Honest Compromise? The Case of Greece. European Public Law. 23 (2017) No. 3: 615.

653 AUER, Dirk. Appropriability and the European Commission's Android Investigation. Columbia Journal of European Law. 23 (2017) No. 3: 647.

654 AWASTHI, Atul. Transformation of Tax Laws: A Global Perspective. Intertax. 45 (2017) No. 2: 175.

655 AZAR, José; Schmalz, Martin C. Common Ownership of Competitors Raises Antitrust Concerns. Journal of European Competition Law and Practice. 8 (2017) No. 5: 329.

656 BACKHAUS, Juergen G. Lawyers' Economics Versus Economic Analysis of Law: A Critique of Professor Posner's 'Economic' Approach to Law by Reference to a Case Concerning Damages for Loss of Earning Capacity. European Journal of Law and Economics. 43 (2017) No. 3: 517.

657 BÁEZ MORENO, Andrés. GAARs and Treaties: From the Guiding Principle to the Principal Purpose Test. What Have We Gained from BEPS Action 6. Intertax. 45 (2017) No. 6/7: 432.

658 BAKER, Philip; Pistone, Pasquale. BEPS Action 16: The Taxpayers' Right to an Effective Legal Remedy Under European Law in Cross-Border Situations. EC Tax Review. 25 (2016) No. 5/6: 335.

659 BAKÓ, Barna. Exclusive Contracts with Private Information in Successive Differentiated Oligopolies. European Journal of Law and Economics. 42 (2016) No. 3: 539.

660 BALP, Gaia. Regulating Proxy Advisors Through Transparency: Pros and Cons of the EU Approach. European Company and Financial Law Review. 14 (2017) No. 1: 1.

661 BARBIER DE LA SERRE, Éric. UPS/TNT: Taking the Right to be Heard Seriously. Journal of European Competition Law and Practice. 8 (2017) No. 8: 502.

662 BARBIER DE LA SERRE, Eric; Lagathu, Eileen. The Law on Fines Imposed in EU Competition Proceedings: Time for a Refresh of the Fining Guidelines? Journal of European Competition Law and Practice. 8 (2017) No. 6: 409.

663 BARTALEVICH, Dzmitry. EU Competition Policy and U.S. Antitrust: A Comparative Analysis. European Journal of Law and Economics. 44 (2017) No. 1: 91.

664 BARTOLACELLI, Alessio. The New Italian Almost Capital-less Private Companies: A Brand New Tile in the Mosaic. European Company and Financial Law Review. 13 (2016) No. 4: 665.

665 BARTOSCH, Andreas. On Our Quarterly's 15th Birthday or on How to Remedy a Market Failure [Editorial]. European State Aid Law Quarterly. 16 (2017) No. 2: 145.

666 BASAK, Sayan. Equalization Levy: A New Perspective of E-Commerce Taxation. Intertax. 44 (2016) No. 11: 845.

667 BATCHELOR, Bill. Digital Disruption: The Practical Implications of the EU's Digital Single Market Agenda. European Competition Law Review. 36 (2015) No. 9: 379.

668 BATCHELOR, Bill. Insurance Block Exemption Regulation: EU Commission Challenges Statistics and Co-(Re)insurance Exemptions. European Competition Law Review. 37 (2016) No. 7: 261. 
669 BATCHELOR, Bill. Lundbeck Raises more Questions than Answers on 'Pay-forDelay' Settlements; Creates Damaging Divergence from US Law. European Competition Law Review. 38 (2017) No. 1: 3.

670 BAVOSO, Vincenzo. Filling the Accountability Gap in Structured Finance Transactions: The Case for a Broader Fiduciary Obligation. Columbia Journal of European Law. 23 (2017) No. 2: 369.

671 BECKERS, Anna. The Regulation of Market Communication and Market Behaviour: Corporate Social Responsibility and the Directives on Unfair Commercial Practices and Unfair Contract Terms. Common Market Law Review. 54 (2017) No. 2: 475.

672 BEHN, Daniel; Fauchald, Ole Kristian; Léetourneau-Tremblay, Laura. Promoting Renewable Energy in the EU: Shifting Trends in Member State Policy Space. European Business Law Review. 28 (2017) No. 2: 217.

673 BERETTA, Giorgio. The Brisal and KBC Finance Decision: Once Again the CJEU Assesses the Compatibility with EU Law of Gross Withholding Taxation of Nonresidents. EC Tax Review. 26 (2017) No. 4: 193.

674 BERETTAM Giorgio. Taxation of Individuals in the Sharing Economy. Intertax. 45 (2017) No. 1: 2.

675 BERG, Werner. Under the Radar of Public Attention? EU Merger Control 2016. European Competition Law Review. 38 (2017) No. 6: 251.

676 BERGPÓRRSON, Andri Fannar. Symposium Discussion Report: Fourth Session Improving Market Effectiveness: Intermediaries, Infrastructures, and the Broader Legal Framework. European Company and Financial Law Review. 14 (2017) No. 2: 391.

677 BERNAT, Michat. Practitioner's (Biased) Diary on What Beneficiaries Complain About (Mainly in Conference Rooms). European State Aid Law Quarterly. 15 (2016) No. 2: 199.

678 BERNATT, Maciej. McWane and Judicial Review of Federal Trade Commission Decisions: Any Inspirations for EU Competition Law? European Competition Law Review. 38 (2017) No. 6: 288.

679 BIANCO, Giuseppe. European Union's Investment Agreements and Public Debt. European Business Law Review. 28 (2017) No. 2: 119.

680 BINDER, Jens-Hinrich. Cross-border Coordination of Bank Resolution in the EU: All Problems Resolved? European Company and Financial Law Review. 13 (2016) No. 4: 575.

681 BIOLAN, Pete Alexandru. Reopening EU Competition Investigations After Judicial Annulment: Beyond Procedural Errors. Journal of European Competition Law and Practice. 8 (2017) No. 2: 83.

682 BIOLAN, Petre Alexandru. The Court of Justice's Rulings in the Bathroom Fittings Cartel Cases: Single/Continuous Infringement and Fines for 'Minor' Participants. Journal of European Competition Law and Practice. 8 (2017) No. 6: 385.

683 BISMUTH, Régis. The 'Santiago Principles' for Sovereign Wealth Funds: The Shortcomings and the Futility of Self-Regulation. European Business Law Review. 28 (2017) No. 1: 69.

684 BIZIOLI, Gianluigi. Taking EU Fundamental Freedoms Seriously: Does the AntiTax Avoidance Directive Take Precedence over the Single Market? EC Tax Review. 26 (2017) No. 3: 167.

685 BLIZKOVSKY, Petr. G20 Economic Coordination and the Rule of Law: A Case of Taxation. European Business Law Review. 28 (2017) No. 3: 271.

686 BLOCKX, Jan. The Belgian Excess Profit Exemption: Tax Incentives for Multinational Groups as State Aid. Journal of European Competition Law and Practice. 8 (2017) No. 1: 25. 
687 BOBELDIJK, Arco; Hendriks, Tim. Interest Deduction in the Netherlands: Tax Aspects of the Different Interest Deduction Limitation Rules. Intertax. 45 (2017) No. 4: 322 .

688 BOGOJEVIC, Sanja; Petit, Nicolas. Deterring the State versus the Firm: Soft and Hard Deterrence Regimes in EU Law. Columbia Journal of European Law. 23 (2016) No. 1: 55 .

689 BORG OLIVIER, Timothy. Developments in the Analysis of the Tie-Breaker Rules for Individuals Under Article 4 (1) OECD. Intertax. 45 (2017) No. 1: 82.

690 BORLINI, Leonardo; Dordi, Claudio. Deepening International Systems of Subsidy Control: The (Different) Legal Regimes of Subsidies in the EU Bilateral Preferential Trade Agreements. Columbia Journal of European Law. 23 (2017) No. 3: 551.

691 BORREGO, Luis M.P. Changing the Paradigm of Shipping Activities' Taxation in Portugal. Intertax. 45 (2017) No. 6/7: 489.

692 BOSCHMA, Hylda; Schutte-Veenstra, Hanny. Will the SUP Be an Effective Legal Form for SMEs as Well as for Subsidiaries within the European Union. European Journal of Comparative Law and Governance. 4 (2017) No. 3: 246 pp.

693 BOSE, Debadatta. From Lax to Tax: India's Changing Policy on Overseas Taxation. Intertax. 45 (2017) No. 4: 341.

694 BOSMAN, Alexander. General Aspects of the Multilateral Instrument. Intertax. 45 (2017) No. 10: 642.

695 BOSMAN, Alexander. Redefining the Relation Between Articles 6, 7 and 21 of the OECD Model. Intertax. 45 (2017) No. 1: 38.

696 BOTTA, Marco. The Draft Directive on the Powers of National Competition Authorities: The Glass Half Empty and Half Full. European Competition Law Review. 38 (2017) No. 10: 470.

697 BOTTA, Marco. The Principle of Passing on in EU Competition Law in the Aftermath of the Damages Directive. European Review of Private Law. 25 (2017) No. 5: 881.

698 BOUCHAGIAR, Antonios. The Binding Effects of Guidelines on the Compatibility of State Aid: How Hard is the Commission's Soft Law? Journal of European Competition Law and Practice. 8 (2017) No. 3: 157.

699 BOULOGNE, Frederik. Shortcomings in the European Union Merger Directive: Lessons for Future Harmonization. Intertax. 44 (2016) No. 11: 810.

700 BOVENZI, Fiorenzo; Lund, Christian; de Juan. Maria Munoz. Icelandic Power Sale Contracts: The MEO Test When an Adequate Benchmark Is Not Readily Available Case Law Annotations. European State Aid Law Quarterly. 15 (2016) No. 2: 291.

701 BRAUN, Alexandra. The Risk of 'Misusing' Trusts: Some Lessons from the Italian Experience. European Review of Private Law. 24 (2016) No. 6: 1119.

702 BRAUNER, Yariv. Brexit: A Note from the United States. Intertax. 44 (2016) No. 12: 882.

703 BREEN, Oonagh B. Guardians of the Charitable Realm: Charitable Trust Supervision Practice and Procedure in the Common Law World. European Review of Private Law. 24 (2016) No. 6: 1141.

704 BRENER, Alan. No-Man is an Island: UK and EU Banking Engagement after 'Brexit'. European Business Law Review. 27 (2016) No. 7: 1029.

705 BRESSERS, Luuk. Damages for Delay: The EU Held Liable for Harm Caused by 'Unjustified Inactivity' in General Court Proceedings. Journal of European Competition Law and Practice. 8 (2017) No. 8: 492.

706 BRINK, Martin. Corporate Mediation in the Netherlands. European Company Law. 14 (2017) No. 2: 91. 
707 BROKELMANN, Helmut; Ganino, Mariarosaria. DTS v Commission: When is a Tax Measure State Aid? Journal of European Competition Law and Practice. 8 (2017) No. 2: 102 .

708 BURKE, Jarleth M. The General Court Endorses the Balancing Approach to Compatibility Assessment by the Commission for Czech Funding of Sports Facilities Case Law Annotations. European State Aid Law Quarterly. 15 (2016) No. 3: 446 .

709 BUSCH, Danny. Governance of the European Banking Union's Single Resolution Mechanism. European Business Law Review. 28 (2017) No. 4: 447.

710 BUSCH, Danny. The Private Law Effect of MifID: The Genil Case and Beyond. European Review of Contract Law. 13 (2017) No. 1: 70.

711 BUTS, Caroline; Nicolaides, Phedon. Manufacturing in Small Peripheral Island States: Where Is the Level Playing Field Opinions. European State Aid Law Quarterly. 16 (2017) No. 2: 272.

712 BUTS, Caroline; Romainville, Jean-Francois; Bilsen, Valentijn. Evaluating Restructuring Aid: A Case Study Approach. European State Aid Law Quarterly. 15 (2016) No. 3: 338

713 CACHIA, Franklin. Aggressive Tax Planning: An Analysis from an EU Perspective. EC Tax Review. 26 (2017) No. 5: 257.

714 CACHIA, Franklin. Analysing the European Commission's Final Decisions on Apple, Starbucks, Amazon and Fiat Finance \& Trade. EC Tax Review. 26 (2017) No. $1: 23$.

715 CALLOL, Pedro. Antitrust Damages Litigation - Key Aspects of Cartel Damages Cases in Spain. European Competition Law Review. 38 (2017) No. 8: 374.

716 CAMERON, Charles M.; Kornhauser, Lewis A. Rational Choice Attitudinalism? European Journal of Law and Economics. 43 (2017) No. 3: 535.

717 CAMERON, Iain. Balancing Data Protection and Law Enforcement Needs: Tele2 Sverige and Watson. Common Market Law Review. 54 (2017) No. 5: 1467.

718 CAMESASCA, Peter D.; Grelier, Laurie-Anne. 'Close Your Eyes'? Navigating the Tortuous Waters of Conscious Parallelism and Signalling in the European Union. Journal of European Competition Law and Practice. 7 (2016) No. 9: 599.

719 CAMISÃO, Isabel; Guimarães, Maria Helena. The Commission, the Single Market and the Crisis: The Limits of Purposeful Opportunism. Journal of Common Market Studies. 55 (2017) No. 2: 223.

720 CANAPA, Damiano. Groupement des Cartes Bancaires (referral to the General Court): Finding of a Restriction by Effect in the Absence of a Restriction by Object. Journal of European Competition Law and Practice. 7 (2016) No. 9: 611.

721 CANAPA, Damiano. Trademarks and Brands in Merger Control: An Analysis of the European and Swiss Legal Orders. European Competition Law Review. 38 (2017) No. 6: 298.

722 CANNAS, Francesco. Reduced Rates and the Digital Economy: The Treatment of (E-)Books Highlights Some Possible Inconsistencies of the EU VAT System. EC Tax Review. 26 (2017) No. 2: 96.

723 CANTERO GAMITO, Marta. Regulation.com. Self-Regulation and Contract Governance in the Platform Economy: A Research Agenda. European Journal of Legal Studies. 9 (2017) No. 2: 53 pp.

724 CAPRIGLIONE, Francesco. UK Referendum and Brexit Hypothesis: The Way Out Perspective and the Convenience to 'Remain United'. European Business Law Review. 27 (2016) No. 7: 887. 
725 CARRIERO, Veronica. Bank Rescues and Legal Challenges: The Case of Bail In. European Business Law Review. 28 (2017) No. 5: 635.

726 CASH, Daniel. Artificially Increasing Competition in the Credit Rating Industry: The ESMA Meets an Immovable Object. European Company Law. 14 (2017) No. 5: 190.

727 CASH, Daniel. Vladimir Putin's Analytical Credit Rating Agency: The Importance of Perception. European Company Law. 14 (2017) No. 3: 112.

728 CAUFFMAN, Caroline. Procedural Rights in Competition Law in the EU and China. European Competition Law Review. 38 (2017) No. 2: 97.

729 CAUFFMAN, Caroline; Smits, Jan. The Sharing Economy and the Law: Food for European Lawyers. Maastricht Journal of European and Comparative Law. 23 (2016) No. 6: 903.

730 CHAND, Vikram. Transfer Pricing Aspects of Intra - Group Loans in Light of the Base Erosion and Profit Shifting Action Plan. Intertax. 44 (2016) No. 12: 885.

731 CHITMIRA, Howard. A Historical Overview of the General Implementation of the European Union Market Abuse Directive in the United Kingdom before Brexit and Its Future Implications. Maastricht Journal of European and Comparative Law. 24 (2017) No. 2: 217.

732 CHIU, Yen-Lin Agnes. The AIIB and the EU: Legal Opportunities and Risks. European Business Law Review. 28 (2017) No. 5: 689.

733 CLOT, Sophie; Grolleau, Gilles; Ibanez, Lisette. Do Good Feeds Make Bad People? European Journal of Law and Economics. 42 (2016) No. 3: 491.

734 COlangelo, Giuseppe; Maggiolino, Mariateresa. Data Protection in Attention Markets: Protecting Privacy through Competition? Journal of European Competition Law and Practice. 8 (2017) No. 6: 363.

735 COLAnGelo, Margherita. Parity Clauses and Competition Law in Digital Marketplaces: The Case of Online Hotel Booking. Journal of European Competition Law and Practice. 8 (2017) No. 1: 3.

736 COLOMBO, Carlo; Eliantonio, Mariolina. Harmonized Technical Standards as Part of EU Law: Juridification with a Number of Unresolved Legitimacy Concerns (Case Note). Maastricht Journal of European and Comparative Law. 24 (2017) No. 2: 323.

737 COLOMO, Pablo Ibanez. State Aid as a Tool to Achieve Technology Neutrality Case Law Annotations. European State Aid Law Quarterly. 15 (2016) No. 3: 440.

738 COOK, Christopher; Novak, Vladimir; Frisch, Sven. Recent Developments in EU Merger Remedies. Journal of European Competition Law and Practice. 8 (2017) No. 5: 341.

739 CORDEWENER, Axel. Anti-Abuse Measures in the Area of Direct Taxation: Towards Converging Standards under Treaty Freedoms and EU Directives? EC Tax Review. 26 (2017) No. 2: 60.

740 CORRADI, Marco Claudio. Corporate Opportunities Doctrines Tested in the Light of the Theory of the Firm - a European (and US) Comparative Perspective. European Business Law Review. 27 (2016) No. 6: 755.

741 CORREDOR VELÁSQUEZ, David O. Tax Treaty Interpretation: Interaction Between Article 3(2) Organisation for Economic Co-Operation and Development Model Convention and Article 31 Vienna Convention. Intertax. 44 (2016) No. 12: 960.

742 COSTA-CABRAL, Francisco; Lynskey, Orla. Family Ties: The Intersection Between Data Protection and Competition in EU Law. Common Market Law Review. 54 (2017) No. 1: 11 .

743 COUTRELIS, Nicole; Caussanel, Sandra. France News from the Member States. European State Aid Law Quarterly. 16 (2017) No. 1: 103. 
744 CREAMER, Shane. The Principle of Sovereignty, Jurisdiction and Ireland's Relationship with Europe. European Business Law Review. 28 (2017) No. 5: 713.

745 CREMERS, Katrin; Ernicke, Max; Gaessler, Fabian. Patent Litigation in Europe. European Journal of Law and Economics. 44 (2017) No. 1: 1.

746 CULliS, John; Morley, Bruce. A Methodology for Determining the 'Cash Economy' in the European Union Via an Announcement Effect. European Journal of Law and Economics. 44 (2017) No. 1: 113.

747 CYNDECKA, Malgorzata Agnieszka. The FIH-Case and the MEIP - A Step Forward or a Step in the Wrong Direction Case Law Annotations. European State Aid Law Quarterly. 16 (2017) No. 1: 86.

748 CYNDECKA, Malgorzata Agniezska. The Applicability and Application of the Market Economy Investor Principle. European State Aid Law Quarterly. 15 (2016) No. 3: 381.

749 DÁCIO ROLIM, João. The General Anti-Avoidance Rule: Its Expanding Role in International Taxation. Intertax. 44 (2016) No. 11: 815.

750 DAMJANOVIC, Dragana. Territorial Restrictions in the Chimney Sweep Business Under the Services Directive: Hiebler. Common Market Law Review. 54 (2017) No. 5: 1535.

751 DAMRO, Chad. European Competition Policy and Globalization. European Competition Law Review. 38 (2017) No. 3: 143.

752 DAVIES, Gareth T. Brexit and the Free Movement of Workers: A Plea for National Legal Assertiveness. European Law Review. 41 (2016) No. 6: 925.

753 DAVILLA, Marixenia. Is Big Data a Different Kind of Animal? The Treatment of Big Data Under the EU Competition Rules. Journal of European Competition Law and Practice. 8 (2017) No. 6: 370.

754 DE BROE, Luc. Can Tax Treaties Confer State Aid? EC Tax Review. 26 (2017) No. 5: 228 .

755 DE BROE, Luc; Beckers, Dorien. The General Anti-Abuse Rule of the Anti-Tax Avoidance Directive: An Analysis Against the Wider Perspective of the European Court of Justice's Case Law on Abuse of EU Law. EC Tax Review. 26 (2017) No. 3: 133.

756 DE CAROLIS, Daniele. A New Approach to International Taxation Dispute Resolution Process (ITDRP). Intertax. 45 (2017) No. 5: 391.

757 DE CAROLIS, Daniele. The Reverberation Effect of the EU Notion of Abuse of Law on the Italian Tax Legal System: Towards an Enhanced Horizontal Interaction Among National General Anti-Abuse Rules? Intertax. 45 (2017) No. 2: 169.

758 DE CONINCK, Raphaël; Hervé, Mikaël. Mergers: How to Measure Local Competition. Journal of European Competition Law and Practice. 8 (2017) No. 6: 402.

759 DE GIOIA-CARABEllesE, Pierre; Chessa, Corrado. Missives and Deposit in Scots Law: Diachronic and Comparative Reflections about the Concept of Arrha. European Business Law Review. 28 (2017) No. 3: 367.

760 DE GROOT, Isabella. Case X (C-283/15) and the Myth of 'Schumacker's 90\% Rule'. Intertax. 45 (2017) No. 8/9: 567.

761 DE GROOT, Isabella. Group Provisions in the Common (Consolidated) Corporate Tax Base. Intertax. 45 (2017) No. 11: 742.

762 DE LA FERIA, Rita. Harmonizing Anti-Tax Avoidance Rules. EC Tax Review. 26 (2017) No. 3: 110 .

763 DE LA FERIA, Rita; Schofield, Max. Towards an [Unlawful] Modernized EU VAT Rate Policy. EC Tax Review. 26 (2017) No. 2: 89. 
764 DE LA PEÑA, Francisco. Gentle Brexit, a very British Exit: EEA Membership as the Most Favourable Model to Secure Financial Services Passports. European Business Law Review. 27 (2016) No. 7: 1057.

765 DE LUCIA, Luca. The Rationale of Economics and Law in the Aftermath of the Crisis: A Lesson from Michel Foucault. European Constitutional Law Review. 12 (2016) No. 3: 445.

766 DE MAILLARD, Jean. Crises Financières, Criminalité et Moralité. European Business Law Review. 28 (2017) No. 1: 55.

767 DE MELO RIGONI, João Marcus. The International Tax Regime in the Twenty-First Century: The Emergence of a Third Stage. Intertax. 45 (2017) No. 3: 205.

768 DE RITA, Monica. Mediation in Corporate Disputes in Italy. European Company Law. 14 (2017) No. 2: 86.

769 DE STEFANO, Gianni. Meet the First Extradited Businessman on Cartel Charges. Journal of European Competition Law and Practice. 8 (2017) No. 5: 281.

770 DE WITTE, Floris. The Constitutional Quality of the Free Movement Provisions: Looking for Context in the Case Law on Article 56 TFEU. European Law Review. 42 (2017) No. 3: 313.

771 DEBELVA, Filip; Mosquera, Irma. Privacy and Confidentiality in Exchange of Information Procedures: Some Uncertainties, Many Issues, but Few Solutions. Intertax. 45 (2017) No. 5: 362.

772 DEKKER, Cees. The Effect on Trade between the Member States' Criterion: Is It the Right Criterion by Which the Commission's Workload Can Be Managed. European State Aid Law Quarterly. 16 (2017) No. 2: 154.

773 DEN HOLLANDER, Wouter. Report from the Netherlands: Dutch Supreme Court Further Defines the Liability of Limited Partners in a Limited Partnership. European Company Law. 14 (2017) No. 3: 130.

774 DERENNE, Jacques. Commission v World Duty Free Group a.o.: Selectivity in (Fiscal) State Aid, Quo Vadis Curia? Journal of European Competition Law and Practice. 8 (2017) No. 5: 311.

775 DETHMERS, Frances. EU Enforcement Policy on Abuse of Dominance: Some Statistics and Facts. European Competition Law Review. 38 (2017) No. 4: 147.

776 DI PIERGIORGIO, Valente. Italian Tax Authorities Action Against Fictitious Corporate Tax Residence. Intertax. 45 (2017) No. 4: 353.

777 DIAS PEREIRA, Alexandre L. Vertical Restraints on Internet Sales in EU Competition Law. European Competition Law Review. 38 (2017) No. 10: 478.

778 DIAZ, Julia Garcia-Royo. Spain News from Member States. European State Aid Law Quarterly. 15 (2016) No. 2: 310.

779 DIJKSTRA, Robert J. Is Limiting Financial Supervisory Liability a Way to Prevent Defensive Conduct? The Outcome of a European Survey. European Journal of Law and Economics. 43 (2017) No. 1: 59.

780 DOMÍNGUEZ-BARRERO, Félix; López-Laborda, Julio. Tax Evasion in Spanish Personal Income Tax by Income Sources, 2005-2008: From the Synthetic to the Dual Tax. European Journal of Law and Economics. 44 (2017) No. 1: 47.

781 DORADO, Ana Paula. The EU Free Movement of Capital and Third Countries: Recent Developments. Intertax. 45 (2017) No. 3: 192.

782 DOS SANTOS, António Carlos; Mota Lopes, Cidália. Tax Sovereignty, Tax Competition and the Base Erosion and Profit Shifting Concept of Permanent Establishment. EC Tax Review. 25 (2016) No. 5/6: 296. 
783 DOUMA, Wybe Th. The Promotion of Sustainable Development through EU Trade Instruments. European Business Law Review. 28 (2017) No. 2: 197.

784 DOURADO, Ana Paula. Free Movement of Capital: The European Union Anti-Tax Avoidance Package and Brexit. Intertax. 44 (2016) No. 12: 870.

785 DOURADO, Ana Paula. The Interest Limitation Rule in the Anti-Tax Avoidance Directive (ATAD) and the Net Taxation Principle. EC Tax Review. 26 (2017) No. 3: 112.

786 DWI ANDRINA, Sukma. Towards a Future Investment Treaty: Lessons from Indirect Expropriation Cases due to Measures to Protect the Environmental and Public Health. European Business Law Review. 28 (2017) No. 2: 245.

787 DWI NUGROHO, Adrianto. Central Register as a Model Instrument to Unveil Beneficial Owners for Tax Purposes. EC Tax Review. 26 (2017) No. 5: 274.

788 ECCLES, Richard [et al.]. Postal Services: Survey of Competition Law Developments. Journal of European Competition Law and Practice. 8 (2017) No. 2: 141.

789 EFTYCHIDOU, T.; Maiorano, F. Once Burned Twice Shy: What Does Economics Say About Repeated Cartel Offences? Journal of European Competition Law and Practice. 7 (2016) No. 9: 622.

790 EGAN, Michelle; Guimarães, Maria Helena. The Single Market: Trade Barriers and Trade Remedies. Journal of Common Market Studies. 55 (2017) No. 2: 294.

791 EIBL, Ferdinand; Lynge-Mangueira, Halfdan. Constraints, Competition, and Competitiveness: Explaining the Non-Linear Effect of Democratization on Political Budget Cycles. European Political Science Review. 9 (2017) No. 4: 629.

792 ELFAR, Mohamed. The Assessment of Challenges to Competition Enforcement in Egypt: The Informal Economy and Governmental Intervention(s). European Competition Law Review. 38 (2017) No. 9: 401.

793 ELIANTONIO, Mariolina. Judicial Control of the EU Harmonized Standards: Entering a Black Hole. Legal Issues of Economic Integration. 44 (2017) No. 4: 395.

794 ELIANTONIO, Mariolina; Medzmariashvili, Megi. Hybridity under Scrutiny: How European Standardization Shakes the Foundations of EU Constitutional and Internal Market Law. Legal Issues of Economic Integration. 44 (2017) No. 4: 323.

795 ENDRESEN, Clement. Taxation and the European Convention for the Protection of Human Rights: Substantive Issues. Intertax. 45 (2017) No. 8/9: 508.

796 ENGSIG SØRENSEN, Karsten; Neville, Mette. Suspension of the Exercise of Voting Rights: A Step Towards Deterrent and Consistent Sanctioning of EU Transparency Requirements? European Company Law. 14 (2017) No. 4: 150.

797 EZCURRA, Marta Villar. The Concept of Environmental Tax in a State Aid Context When a Fiscal Energy Measure Is Concerned Energy and State Aid Control. European State Aid Law Quarterly. 16 (2017) No. 1: 11.

798 EZCURRA, Marta Villar; Maillo, Jeronimo. Environmental and Energy Taxation and State Aid Control: Does the Current Framework Make Sense or Should It Be Adjusted Foreword. European State Aid Law Quarterly. 16 (2017) No. 1: 3.

799 FALCAO, Tatiana. BEPS and the Paris Agreement: Unthinkable Bonds. Intertax. 45 (2017) No. 11: 688.

800 FAngFei WANG, Faye. Big Data Regulatory Debates in the EU. European Business Law Review. 28 (2017) No. 4: 593.

801 FARRAND, Benjamin. Bold and Newly Independent, or Isolated and Cast Adrift? The Implications of Brexit for Intellectual Property Law and Policy. Journal of Common Market Studies. 55 (2017) No. 6: 1306. 
802 FAUROUX, Christine; Dunne, Ronan. Ireland News from the Member States. European State Aid Law Quarterly. 16 (2017) No. 1: 99.

803 FAUSTINELLI, Elisa. Purely Internal Situations and the Freedom of Establishment within the Context of the Services Directive [Case Review]. Legal Issues of Economic Integration. 44 (2017) No. 1: 77.

804 FERNÁNDEZ-SAMANIEGO, Javier; Gutiérrez Garcia de Cortázar, Elena; Prats Albentosa, Lorenzo; Romero, Nazareth; Vilatoro, Tomás. Mediation in Corporate Disputes in Spain. European Company Law. 14 (2017) No. 2: 98.

805 FERRERA, Maurizio. The Contentious Politics of Hospitality: Intra-EU Mobility and Social Rights. European Law Journal. 22 (2016) No. 6: 791.

806 FERRER-I-CARBONELL, Ada; Gërxhani, Klarita. Tax Evasion and Well-Being: A Study of the Social and Institutional Context in Central and Eastern Europe. European Journal of Political Economy. (2016) No. 45 Supplement: 149.

807 FIBBE, G. K. ( Gijs); Stevens, A. J. A. (Ton). Hybrid Mismatches Under the ATAD I and II. EC Tax Review. 26 (2017) No. 3: 153.

808 FISCHER, Mira; Kauder, Björn; Potrafke, Niklas; Ursprung, Heinrich W. Support for Free-Market Policies and Reforms: Does the Field of Study Influence Students' Political Attitudes? European Journal of Political Economy. (2017) No. 48: 180.

809 FLETCHER, Amelia. Exploitation of Consumer Decision-making and How to Address it: Lessons From Past Demand-side Interventions. Journal of European Competition Law and Practice. 8 (2017) No. 8: 517.

810 FLORIS DE WILDE, Maarten. Lowering the Permanent Establishment Threshold via the Anti-BEPS Convention: Much Ado About Nothing? Intertax. 45 (2017) No. 8/9: 556 .

811 FLUIT, Roel. What a US Buyer Should Expect in a Dutch M\&A Transaction. European Company Law. 14 (2017) No. 1: 29.

812 FOUNTOUKAKOS, Kyriakos. DEI v Commission: Application of Article 106 TFEU to Preferential Rights for Electricity Incumbent Post-market Liberalisation. Journal of European Competition Law and Practice. 8 (2017) No. 4: 242.

813 FREITAS DE MORAES E CASTRO, Leonardo; Luiz Moraes do Rêgo Monteiro, Alexandre. Qualification of Services Under Double Tax Treaties in Brazil: Open Issues After Iberdrola Case. Intertax. 45 (2017) No. 1: 54.

814 FROMAGE, Diane; Kreilinger, Valentin. National Parliaments' Third Yellow Card and the Struggle over the Revision of the Posted Workers Directive. European Journal of Legal Studies. 10 (2017) No. 1: 125 pp.

815 GAC, Maciej; Bernatt, Maciej. Rail Freight: How Does Poland Assesses Alleged Abuses by Dominant Firms. Journal of European Competition Law and Practice. 8 (2017) No. 6: 388.

816 GÄCHTER, Martin; Gruber, Alexander; Riedl, Aleksandra. Wage Divergence, Business Cycle Co-Movement and the Currency Union Effect. Journal of Common Market Studies. 55 (2017) No. 6: 1322.

817 GAILLARD, Norbert J. Credible Sovereign Ratings: Beyond Statistics and Regulations. European Business Law Review. 28 (2017) No. 1: 5.

818 GAL, Michal S. Economic Characteristics of Developing Jurisdictions: Their Implications on Competition Law. European Competition Law Review. 38 (2017) No. 5: 247.

819 GAMBARO, Edoardo; Mazzocchi, Francesco. The Changing Nature of Commission Opening Decisions: Yet Another Obstacle to the Access of EU Courts Case Law Annotations. European State Aid Law Quarterly. 15 (2016) No. 2: 299. 
820 GARBARINO, Carlo. Harmonization and Coordination of Corporate Taxes in the European Union. EC Tax Review. 25 (2016) No. 5/6: 277.

821 GARCIA PIRES, Armando J. Media Pluralism and Competition. European Journal of Law and Economics. 43 (2017) No. 2: 255.

822 GARGOURI, Slim. Singapore: Updated Transfer Pricing Guidelines Released by IRAS. Intertax. 45 (2017) No. 5: 427.

823 GAYGER, Michael. Infrastructure Funding at the Interface between the EU State Aid Rules and Member States' General Economic Policy. European State Aid Law Quarterly. 15 (2016) No. 4: 539.

824 GEnEVAZ, Simon; Vidal, Jérôme. Going Digital: How Online Competition Changed Market Definition and Swayed Competition Analysis in Fnac/Darty. Journal of European Competition Law and Practice. 8 (2017) No. 1: 30.

825 GEORGIEVA, Zlatina. Competition Soft Law in French and German Courts: A Challenge for Online Sales Bans Only. Maastricht Journal of European and Comparative Law. 24 (2017) No. 2: 175.

826 GEORGIEVNA IVANOVA, Natalia [et al.]. Transfer Pricing in Russia and Germany: Similarities and Differences. Intertax. 45 (2017) No. 2: 182.

827 GERHARDS, Jürgem; Mutz, Michael. Who Wins the Championship? Market Value and Team Composition as Predictors of Success in the Top European Football Leagues. European Societies. 19 (2017) No. 3: 223.

828 GERNER-BEUERLE, Carsten; Mucciarelli, Federico M.; Schuster, Edmund-Philipp; Siems, Mathias M. The Law Applicable to Companies in Europe: Study and Possible Reform. European Company Law. 14 (2017) No. 4: 148.

829 GHAZARIAN, Peter. Recovery of State Aid. European State Aid Law Quarterly. 15 (2016) No. 2: 228.

830 GIANNINO, Michele. Collusion in Public Contracts Procurement: Suppliers of School Cleaning Services Fined for Bid Rigging (Italy). Journal of European Competition Law and Practice. 8 (2017) No. 4: 247.

831 GIANNINO, Michele. Utopia: The Luxembourg Competition Authority Retrospectively Reviews a Merger on the Ground of Article 102 TFEU. European Competition Law Review. 38 (2017) No. 7: 331.

832 GILL-PEDRO, Eduardo. Freedom to Conduct Business in EU Law: Freedom from Interference or Freedom from Domination? European Journal of Legal Studies. 9 (2017) No. 2: 103 pp.

833 GILOTTA, Sergio. The Regulation of Outsider Trading in EU and the US. European Company and Financial Law Review. 13 (2016) No. 4: 631.

834 GINEVRA, Guglielmo. The EU Anti-Tax Avoidance Directive and the Base Erosion and Profit Shifting (BEPS) Action Plan: Necessity and Adequacy of the Measures at EU Level. Intertax. 45 (2017) No. 2: 120.

835 GIRAUD, Adrien, Petit, Sylvain. IFP v Commission: The Commission Does Not Meet the Standard of Proof Case Law Annotations. European State Aid Law Quarterly. 15 (2016) No. 3: 468.

836 GIRAUD, Adrien; Petit, Sylvain. Bury Them Deep: The Court of Justice Annuls the Autogrill and Banco Santander Judgments of the General Court [Case Law Annotations]. European State Aid Law Quarterly. 16 (2017) No. 2: 310.

837 GIRAUD, Adrien; Petit, Sylvain. Tax Rulings and State Aid Qualification: Should Reality Matter. European State Aid Law Quarterly. 16 (2017) No. 2: 233.

838 GIRAUD, Adrien; Petit, Sylvain. The French Pension Case: The Defence Based on Compensation of Structural Disadvantages Consigned to Oblivion Case Law Annotations. European State Aid Law Quarterly. 16 (2017) No. 1: 82. 
839 GIUSY DE FLORA, Menita. Protection of the Taxpayer in the Information Exchange Procedure. Intertax. 45 (2017) No. 6/7: 447.

840 GLÄßER, Ulla. Corporate Mediation in Germany. European Company Law. 14 (2017) No. 2: 76 .

841 GLUSCHENKO, Sergiy. A $\mathbf{\epsilon}$ Billion Unpaid Fine: The Ukrainian Antitrust Case Against Gazprom. Journal of European Competition Law and Practice. 8 (2017) No. 8: 510.

842 GNES, Matteo. Do Administrative Law Principles Apply to European Standardization: Agencification or Privatization. Legal Issues of Economic Integration. 44 (2017) No. 4: 367.

843 GÖMANN, Merlin. The New Territorial Scope of EU Data Protection Law: Deconstructing a Revolutionary Achievement. Common Market Law Review. 54 (2017) No. 2: 567.

844 GÓMEZ REQUENA, José Ángel. Adapting the Concept of Permanent Establishment to the Context of Digital Commerce: From Fixity to Significant Digital Economic Presence. Intertax. 45 (2017) No. 11: 732.

845 GOMTSIAN, Suren. Exit in Non-Listed Firms: When and How to Use Share Transfer Restrictions? European Business Law Review. 27 (2016) No. 6: 719.

846 GONZALEZ, Saturnina Moreno. State Aid and Tax Competition: Comments on the European Commission's Decisions on Transfer Pricing Rulings. European State Aid Law Quarterly. 15 (2016) No. 4: 556.

847 GOOSSENS, Elise. A Model for the Use of the European Certificate of Succession for Property Registration. European Review of Private Law. 25 (2017) No. 3: 523.

848 GRAEF, Inge. EU Competition Law, Data Protection and Online Platforms: Data as Essential Facility. European Competition Law Review. 38 (2017) No. 9: 433.

849 GRAJZL, Peter; Zajc, Katarina. Litigation and the Timing of Settlement: Evidence from Commercial Disputes. European Journal of Law and Economics. 44 (2017) No. 2: 287 .

850 GRASSO, Roberto. Standard Essential Patents: Royalty Determination in the Supply Chain. Journal of European Competition Law and Practice. 8 (2017) No. 5: 283.

851 GREIL, Stefan. The Dealing at Arm's Length Fallacy: A Way Forward to a FormulaBased Transactional Profit Split? Intertax. 45 (2017) No. 10: 624.

852 GREIL, Stefan; Schilling, Dirk. Cross-Border Financial Transactions and Arm's Length Interest Rates: A Two-Step Approach. Intertax. 44 (2016) No. 11: 802.

853 GRISOSTOLO, Francesco; Scarcella, Luisa. 'Trouble Always Comes in Threes': The Taricco Case Saga and the Italian Limitation Period in VAT Fraud. Intertax. 45 (2017) No. 11: 701.

854 GURGUlA, Olga. Anti-Competitive Patent Acquisitions in the Pharmaceutical Industry. European Competition Law Review. 38 (2017) No. 1: 35.

855 GUTMANN, Daniel; Raingeard de la Blétière, Emmanuel. CC(C)TB and International Taxation. EC Tax Review. 26 (2017) No. 5: 233.

856 H.-Y. CHIU, Iris. Unpacking the Reforms in Europe and UK Relating to Mandatory Disclosure in Corporate Social Responsibility: Instituting a Hybrid Governance Model to Change Corporate Behaviour? European Company Law. 14 (2017) No. 5: 193.

857 HAAS, Georg; Hornuf, Lars. Regulating Fraud in Financial Markets: Can Behavioural Designs Prevent Future Criminal Offences? European Business Law Review. 28 (2017) No. 1: 41. 
858 HAASE, Florian. Reconceptionalization of the 'Immovable Property Clause' in Article 13 Paragraph 4 OECD Model Convention by Means of the Multilateral Instrument? Intertax. 45 (2017) No. 4: 284.

859 HALDRUP, Karin. On Security of Collateral in Danish Mortgage Finance: A Formula of Property Rights, Incentives and Market Mechanisms. European Journal of Law and Economics. 43 (2017) No. 1: 1.

860 HANSEN, Jesper Lau. Market Abuse Case Law -Where Do We Stand With MAR? European Company and Financial Law Review. 14 (2017) No. 2: 367.

861 HARSDORF, Natalie. Digital Economy: New Test in Austrian Merger Control. Journal of European Competition Law and Practice. 8 (2017) No. 7: 421.

862 HARVEY, James. The Rocky Road to Competition - how to Protect Consumers while Competition Develops. European Competition Law Review. 36 (2015) No. 3: 101.

863 HATZOPOUlOS, Vassilis; Roma, Sofia. Caring for Sharing? The Collaborative Economy under EU Law. Common Market Law Review. 54 (2017) No. 1: 81.

864 HAUTBOURG, Stéphane. Commission v France and Orange: Determination of the Moment in Which to Assess the Prudent Private Investor Criterion. Journal of European Competition Law and Practice. 8 (2017) No. 6: 382.

865 HAVU, Katri. Procedure, Duration, Reasoning and Fines: Notes on the Basis of Case C-519/15 P Trafilerie. European Competition Law Review. 38 (2017) No. 7: 316.

866 HEBER, Caroline; Sternberg, Christian. The Extraterritorial Reach of the German Progression Clause in Income Tax Law in the Light of International Law. Intertax. 45 (2017) No. 3: 254.

867 HELBERGER, Natali; Zuiderveen Borgesius, Frederik; Reyna, Agustin. The Perfect Match? A Closer Look at the Relationship Between EU Consumer Law and Data Protection Law. Common Market Law Review. 54 (2017) No. 5: 1427.

868 HELLWIG, Hans-Jürgen. The Effects of Brexit on the Law of Companies and Financial and Legal Services in Europe: A Summary Overview. European Company and Financial Law Review. 14 (2017) No. 2: 252.

869 HERLIN-KARNELL, Ester; Ryder, Nicholas. The Robustness of EU Financial Crimes Legislation: A Critical Review of the EU and UK Anti-Fraud and Money Laundering Scheme. European Business Law Review. 28 (2017) No. 4: 427.

870 HETTNE, Jorgen. Standards, Barriers to Trade and EU Internal Market Rules: Need for a Renewed Approach. Legal Issues of Economic Integration. 44 (2017) No. 4: 409.

871 HILDEBRAND, Doris. The Role of Economic Analysis in EU Competition Law: The European School. European Competition Law Review. 38 (2017) No. 5: 248.

872 HIRSBRUNNER, Simon. How to Please Your Sweethearts When You Are Divorcing: The UK Government's Ability to Offer Incentives to Foreign Investors after Brexit Opinion. European State Aid Law Quarterly. 15 (2016) No. 4: 504.

873 HIRSBRUNNER, Simon; Lauterjung, Alice. Without EU State Aid Control No EU-UK Free Trade Deal Opinions. European State Aid Law Quarterly. 16 (2017) No. 2: 288.

874 HJElmenG, Erling; Søreide, Tina. Bribes, Crimes and Law Enforcement. European Business Law Review. 28 (2017) No. 1: 19.

875 HJELMTVEDT, Karoline. The Decentralization of Enforcement of EU/EEA Competition Law. European Competition Law Review. 38 (2017) No. 2: 60.

876 HÖLSCHER, Jens; Nulsch, Nicole; Stephan, Johannes. State Aid in the New EU Member States. Journal of Common Market Studies. 55 (2017) No. 4: 779.

877 HONORE, Michael. Public Activities on Commercial Markets: The Issue of CrossSubsidisation. European State Aid Law Quarterly. 16 (2017) No. 2: 181. 
878 HONORÉ, Pierre; Vatin, Guillaume. The French Competition Authority's Altice Decision: Record Fine for the First 'Genuine' Gun Jumping Case in Europe. Journal of European Competition Law and Practice. 8 (2017) No. 5: 314.

879 HOPSON, Helen. Genentech: No EU Competition Law Barrier to Patent Royalties Despite Invalidity or Non-infringement of the Licensed Patent(s). Journal of European Competition Law and Practice. 7 (2016) No. 10: 679.

880 HORSMANS, Guy. Belgian Legal Mediation in Corporate Disputes. European Company Law. 14 (2017) No. 2: 61.

881 HORVÁTH, Botond. Development of the Applicability of European Competition Law on Banks as Undertakings. European Competition Law Review. 38 (2017) No. 9: 423.

882 HOSKEN, Daniel; Miller, Nathan; Weinberg, Matthew. Ex Post Merger Evaluation: How Does it Help Ex Ante? Journal of European Competition Law and Practice. 8 (2017) No. 1: 41.

883 HOWARTH, David; Quaglia, Lucia. Brexit and the Single European Financial Market. Journal of Common Market Studies. 55 (2017) No. S1: 149.

884 HUGHES, Paul. Bright Line or Barbed Wire? The Classification of Supplier Influence over Resale Prices under EU Competition Law. European Competition Law Review. 38 (2017) No. 6: 272.

885 HULL, David W.; Clancy, Michael J. The Application of EU Competition Law in the Pharmaceutical Sector. Journal of European Competition Law and Practice. 8 (2017) No. 3: 205 .

886 HUNOLD, Matthias. Best Price Clauses: What Policy as Regards Online Platforms? Journal of European Competition Law and Practice. 8 (2017) No. 2: 119.

887 HUSOVEC, Martin. Intellectual Property Rights and Integration by Conflict: The Past, Present and Future. Cambridge Yearbook of European Legal Studies. 18 (2016): 239.

888 IBÁÑEZ COLOMBO, Pablo. Appreciability and De Minimis in Article 102 TFEU. Journal of European Competition Law and Practice. 7 (2016) No. 10: 651.

889 IBRAHIM, Amir. A European State Aid Approach to the Egyptian Competition Policy in the Area of Public Services: Lessons Learnt from the EU Post-Altmark Regulatory Package. European State Aid Law Quarterly. 15 (2016) No. 4: 603.

890 ILIOPOULOS, Theodoros. The State Aid Cases of Starbucks and Fiat: New Routes for the Concept of Selectivity. European State Aid Law Quarterly. 16 (2017) No. 2: 263.

891 ILMONEN, Klaus R. A Framework for a Nordic Corporate Governance Indeks. European Business Law Review. 28 (2017) No. 3: 283.

892 INDERST, Roman; Mazzarotto. Can the SIEC Test be Used to Assess Effects from Buyer Power? Journal of European Competition Law and Practice. 8 (2017) No. 3: 185.

893 ISMER, Roland; Artinger, Katharina. International Double Taxation Under VAT: Causes and Possible Solutions. Intertax. 45 (2017) No. 10: 593.

894 ISMER, Roland; Jescheck, Christoph. The Substantive Scope of Tax Treaties in a Post-BEPS World: Article 2 OECD MC (Taxes Covered) and the Rise of New Taxes. Intertax. 45 (2017) No. 5: 382.

895 JAEGER, Thomas. Tax Concessions for Multinationals: In or Out of the Reach of State Aid Law? Journal of European Competition Law and Practice. 8 (2017) No. 4: 221.

896 JALLAI, Ave-Geidi; van Hulten, Mart. Report on the 2016 Conference Tax Treaty Case Law Around the Globe. Intertax. 44 (2016) No. 11: 859. 
897 JANKA, Sebastian Felix. Parent Company Liability in German and EU Competition Law: Two Worlds Apart? Journal of European Competition Law and Practice. 7 (2016) No. 9: 614.

898 JANSEN, Pim. The Interplay between Industrial Policy and State Aid: Natural Combination of Strange Bedfellows. European State Aid Law Quarterly. 15 (2016) No. 4: 575 .

899 JASTRZEBBSKI, Jacek. Corporate Directors' Liability in Polish Law. European Company and Financial Law Review. 14 (2017) No. 1: 73.

900 JOSKOVÁ, Lucie. Position of a Trustee: The Capacity to Be a Trustee and a Trustee's Duty of Care. European Review of Private Law. 24 (2016) No. 6: 1075.

901 JULIEN, Rita; Koch, Petra; Szudoczky, Rita. What Has Changed in the Limitation on Benefits Clause of the 2016 US Model?: Technical Modifications, Policy Considerations and Comparisons with Base Erosion and Profit Shifting Action 6. Intertax. 45 (2017) No. 1: 12.

902 KADAR, Massimiliano; Bogdan, Mateusz. 'Big Data' and EU Merger Control - A Case Review. Journal of European Competition Law and Practice. 8 (2017) No. 8: 479.

903 KALIMO, Harri; Majcher, K. The Concept of Fairness: Linking EU Competition and Data Protection Law in the Digital Marketplace. European Law Review. 42 (2017) No. 2: 210.

904 KALLESTRUP, Morten. Stakeholder Participation in European Standardization: A Mapping and an Assessment of Three Categories of Regulation. Legal Issues of Economic Integration. 44 (2017) No. 4: 381.

905 KAMBJERRE, Andreas Sams. Symposium Discussion Report: First Session The State of the (Capital) Union. European Company and Financial Law Review. 14 (2017) No. 2: 268.

906 KAMBJERRE, Andreas Sams. Symposium Discussion Report: Second Session Improving Access to Finance. European Company and Financial Law Review. 14 (2017) No. 2: 314

907 KAMBJERRE, Andreas Sams. Symposium Discussion Report: Third Session Developing and Diversifying the Supply of Funding. European Company and Financial Law Review. 14 (2017) No. 2: 364.

908 KAPlanOGLOU, Georgia; Rapanos, Vassilis T. Tax Compliance Behaviour During the Crisis: The Case of Greek SMEs. European Journal of Law and Economics. 42 (2016) No. 3: 405.

909 KARAPAPA, Stavroula. The Requirement for a 'New Public' in EU Copyright Law. European Law Review. 42 (2017) No. 1: 63.

910 KEKELEKIS, Mihalis. Stretching the Concept of Existing Aid Alterations and the New Role of National Courts in State Aid Proceedings Case Law Annotations. European State Aid Law Quarterly. 16 (2017) No. 2: 291.

911 KEMMEREN, Eric C. C. M. Gross Withholding Taxes: Is the Court of Justice of the European Union Back on Track with Regard to Deductible Expenses? EC Tax Review. 26 (2017) No. 1: 2.

912 KINGSBURY, Anna. Media Mergers: Is Competition Law Enough? European Competition Law Review. 38 (2017) No. 1: 8.

913 KLEIST, David. A Multilateral Instrument for Implementing Changes to Double Tax Treaties: Problems and Prospects. Intertax. 44 (2016) No. 11: 823.

914 KOKKINIS, Andreas. The Impact of Brexit on the Legal Framework for Cross-Border Corporate Activity. European Business Law Review. 27 (2016) No. 7: 959.

915 KOKOTT, Juliane; SOBOTTA, Christoph. Investment Arbitration and EU Law. Cambridge Yearbook of European Legal Studies. 18 (2016): 3. 
916 KONTOGEORGA, Georgia N. Does (Better) Regulation Really Matter? Examining Public Financial Management Legislation in Greece. European Journal of Law and Economics. 43 (2017) No. 1: 153.

917 KORNILAKIS, Angelos. Report from Greece: The New Law on Social Enterprises in Greece. European Company Law. 14 (2017) No. 5: 209.

918 KOROTANA, Muahmmed. The Emergence of Regulation: Market Failure, Subversion of Justice and Inadequacy of Private Law. European Business Law Review. 28 (2017) No. 5: 615 .

919 KOTTA KYRIAKOU, Thomais. Harmonizing Corporate Actions for the Achievement of a Capital Markets Union: An analysis of the Shareholders' Rights Directive, the Green Paper 'Building a Capital Markets Union' and TARGET2-Securities. European Company Law. 14 (2017) No. 3: 121.

920 KOVÁCS, Ákos. Information Exchange: Infringement Based Solely on Potential Restrictive Effects in the Wake of the Hungarian BankAdat Case? Journal of European Competition Law and Practice. 8 (2017) No. 2: 108.

921 KR. SHARMA, Ajay. How to Axe a Double Taxation Avoidance Agreement: Analysing Section 94A of the Indian Income Tax Act. Intertax. 44 (2016) No. 11: 838.

922 KRAMLER, Thomas. The European Commission's E-commerce Sector Inquiry. Journal of European Competition Law and Practice. 8 (2017) No. 2: 81.

923 KRAMLER, Thomas. The European Commission's E-commerce Sector Inquiry. Journal of European Competition Law and Practice. 8 (2017) No. 2: 81.

924 KRZYSTOFEK, Mariusz. 'The Right to be Forgotten' on a Swing. European Business Law Review. 27 (2016) No. 6: 865.

925 KUBE, Hanno; Reimer, Ekkehart; Spengel, Christpoh. Tax Policy: Trends in the Allocation of Powers Between the Union and Its Member States. EC Tax Review. 25 (2016) No. 5/6: 247.

926 KUIJPERS, Matthijs; Tuinenga, Stefan; Whiteford, Elaine; Paul, Thomas B. Actions for Damages in the Netherlands, the United Kingdom, and Germany. Journal of European Competition Law and Practice. 8 (2017) No. 1: 47.

927 KULMS, Rainer. Trusts as Vehicles for Investment. European Review of Private Law. 24 (2016) No. 6: 1091.

928 KUMAR SINGH, Manoj. Taxation of Digital Economy: An Indian Perspective. Intertax. 45 (2017) No. 6/7: 467.

929 KUMPAN, Christoph. Market-based financing in the Capital Markets Union: The European Commission's Proposals to Foster Financial Innovation in the EU. European Company and Financial Law Review. 14 (2017) No. 2: 336.

930 KURGONAITE, Evelina. Two Vintage Years in a Row? Journal of European Competition Law and Practice. 8 (2017) No. 1: 1.

931 KYRIAZIS, Dimitrios A. From Soft Law to Soft Law through Hard Law: The Commission's Approach to the State Aid Assessment of Tax Rulings. European State Aid Law Quarterly. 15 (2016) No. 3: 428.

932 LAGZDINA, Daiga. Estonia News from Member States. European State Aid Law Quarterly. 15 (2016) No. 2: 322.

933 LAINA, Flavio; Bogdanov, Aleko. The EU Cartel Settlement Procedure: Latest Developments. Journal of European Competition Law and Practice. 8 (2017) No. 5: 333.

934 LALLEMAND-KIRCHE, Geneviève; Tixier, Caroline; Piffaut, Henri. The Treatment of State-owned Enterprises in EU Competition Law: New Developments and Future Challenges. Journal of European Competition Law and Practice. 8 (2017) No. 5: 295. 
935 LALLEMAND-KIRCHE, Geneviève; Tixier, Caroline; Piffaut, Henri. The Treatment of State-owned Enterprises in EU Competition Law: New Developments and Future Challenges. Journal of European Competition Law and Practice. 8 (2017) No. 7: 475.

936 LAMADRID DE PABLO, Alfonso. Competition Law as Fairness. Journal of European Competition Law and Practice. 8 (2017) No. 3: 147.

937 LAMBERTS, Paul B.W.L. Fair Taxation: Truth is in the Eye of the Beholder. Intertax. 45 (2017) No. 1: 49.

938 LAMBRECHT, Maxime. The Time Limit on Copyright: An Unlikely Tragedy of the Intellectual Commons. European Journal of Law and Economics. 43 (2017) No. 3: 475.

939 LAPENTA, Gaetano. Vers un Marché Unique Numérique: Géoblocage et Portabilité Transfrontière des Services de Contenu en Ligne dans 1'UE. European Journal of Legal Studies. 9 (2017) No. 2: 135.

940 LAWRANCE, Sophie; Bond, Edwin; Hunt, Matthew. Genentech, Lundbeck, Paramount and Others: A Survey of Cases at the Intersection Between Competition Law and IP Law in the Past Year. Journal of European Competition Law and Practice. 8 (2017) No. 1: 66.

941 LEESON, Peter T.; Pierson, Joshua. Economic Origins of the No-Fault Divorce Revolution. European Journal of Law and Economics. 43 (2017) No. 3: 419.

942 LEHMANN, Matthias. A Question of Coherence: The Proposals on EU Contract Rules on Digital Content and Online Sales. Maastricht Journal of European and Comparative Law. 23 (2016) No. 5: 752.

943 LEHMANN, Matthias; Zetzsche, Dirk. Brexit and the Consequences for Commercial and Financial Relations between the EU and the UK. European Business Law Review. 27 (2016) No. 7: 999.

944 LEIGH, Hancher. Can the Treaty State Aid Regime Come to the Rescue of Climate Change Editorial. European State Aid Law Quarterly. 16 (2017) No. 1: 1.

945 LENK, Hannes. Investment Arbitration under EU Investment Agreements: Is There a Role for an Autonomous EU Legal Order? European Business Law Review. 28 (2017) No. 2: 135.

946 LEVEY, Marc M.; Minkovich, Alexandra; Odintz, Joshua D.; Rimpfel, Kathryn E. Understanding the Legislative Process and Political Realities Behind Enacting US Tax Reform. Intertax. 45 (2017) No. 10: 660.

947 LEVY, Richard E. The Law and Economics of Supranationalism: The European Union and the Subsidiarity Principle in Collective Action Perspective. European Journal of Law and Economics. 43 (2017) No. 3: 441.

948 LI, Na. Tax Sparing: Use It, But Not as a Foreign Aid Tool. Intertax. 45 (2017) No. 8/9: 546.

949 LIBERATI BUCCIANTI, Giovanni. Report from Italy: Recent Developments on the Fining Policy of the Italian Financial Market Authority (CONSOB). European Company Law. 14 (2017) No. 3: 127.

950 LINDEMANS, Gillis. The Walls Have Fallen, Run for the Keep: Insolvency Law as the New Company Law for Third Parties. European Review of Private Law. 24 (2016) No. 5: 877 .

951 LINDSAY, Alistair. Brexit, Merger Control and Potential Reforms. European Competition Law Review. 38 (2017) No. 10: 435.

952 LINKLATER-SAHM, Emma. Exhausted by Exhaustion? ECJ Says Back Up Copies of Computer Programs Cannot Be Sold, even if the Original Disk is Lost, Damaged or Stolen. European Law Reporter. (2016) No. 6: 241. 
953 LIPINSKY, Julia; Wolters, Jan. Time Will Tell - A Brief Contemplation on the Temporal Application of Substantive State Aid Rules in the Light of the Recent Anderen-Judgment of CJEU. European State Aid Law Quarterly. 15 (2016) No. 2: 193.

954 LISZT, Marijana; Butorac Malnar, Vlatka. SGEI in Croatia: The Legal Framework for Economic Necessity. European State Aid Law Quarterly. 15 (2016) No. 4: 622.

955 LÓPEZ LLOPIS, Estefanía. Formulary Apportionment in the European Union. Intertax. 45 (2017) No. 10: 631.

956 LOVDAHL GORMSEN, Liza; Mifsud-Bonnici, Clement. Legitimate Expectation of Consistent Interpretation of EU State Aid Law: Recovery in State Aid Cases Involving Advanced Pricing Agreements on Tax. Journal of European Competition Law and Practice. 8 (2017) No. 7: 423.

957 LU, Longjie. The End of Bankers' Bonus Cap: How Will the UK Regulate Bankers. European Business Law Review. 27 (2016) No. 7: 1091.

958 LUCCHINI, Stefano[et al.]. State Aid and the Banking System in the Financial Crisis: From Bail-out to Bail-in. Journal of European Competition Law and Practice. 8 (2017) No. 2: 88.

959 LUJA, Raymond H. C. Do State Aid Rules Still Allow European Union Member States to Claim Fiscal Sovereignty? EC Tax Review. 25 (2016) No. 5/6: 312.

960 LUJA, Raymond. Just a Notion of Aid: How (Not) to Create a Fiscal State Aid Doctrine. Intertax. 44 (2016) No. 11: 788.

961 LUNDQVIST, Bjorn. European Harmonized Standards as Part of EU Law: The Implications of the James Elliott Case for Copyright Protection and, Possible, for EU Competition Law. Legal Issues of Economic Integration. 44 (2017) No. 4: 421.

962 LYKOTRAFITI, Antigoni. The White Elephant in the Room Case Law Annotations. European State Aid Law Quarterly. 16 (2017) No. 2: 299.

963 MA, Giai-Mau. Subcontracting Services to a Company and a Permanent Establishment According to Article 5 Paragraph 3 Letter b) UN-Model-Convention. Intertax. 45 (2017) No. 6/7: 461.

964 MACCULLOCH, Angus. State Intervention in Pricing: An Intersection of EU Free Movement and Competition Law. European Law Review. 42 (2017) No. 2: 190.

965 MACLEnNAN, Jacquelyn; Kadri, Aqeel. Toshiba v Commission: Court of Justice Eases Burden on Commission to Fine Parent Companies for Competition Law Infringements by Joint Ventures. Journal of European Competition Law and Practice. 8 (2017) No. 4: 245.

966 MACLENNAN, Stuart. The Questionable Legality of the Diverted Profits Tax Under Double Taxation Conventions and European Union Law. Intertax. 44 (2016) No. 12: 903.

967 MAGGIO, Elena. Relationship and Agreement on App Distribution Platforms. European Competition Law Review. 38 (2017) No. 8: 381.

968 MAGgiO, Elena. The Competitive Dynamics of App Distribution Platforms: To Be Or Not To Be Open? Part 2. European Competition Law Review. 38 (2017) No. 9: 391.

969 MAIER, Christoph; Schanz, Deborah. Convergence of Dividend and Capital Gains Taxation in the European Union from 1990 to 2015. Intertax. 44 (2016) No. 12: 913.

970 MAILlO, Jeronimo. Balancing Environmental Protection, Competitiveness and Competition: A Critical Assessment of the GBER and EEAG Energy and State Aid Control. European State Aid Law Quarterly. 16 (2017) No. 1: 4.

971 MAITROT DE LA MOTTE, Alexandre. The Recovery of the Illegal Fiscal State Aids: Tax Less to Tax More. EC Tax Review. 26 (2017) No. 2: 75. 
972 MALBERTI, Corrado. Fiduciary Arrangements in Civil Law Countries: Framing the Trustee's Role and Duties. European Review of Private Law. 24 (2016) No. 6: 1053.

973 MARCHESINI MASCHERONI, Davide. Report from Switzerland: Restrictions to Infra-Group Financial Arrangements and Cash Pooling Under Swiss Law. European Company Law. 14 (2017) No. 3: 132.

974 MARINI-BALESTRA, Federico. Digital Markets and Merger Control: Balancing Big Data and Privacy Against Competition Law - a Comment on the European Commission's Decision in the Microsoft/LinkedIn Merger. European Competition Law Review. 38 (2017) No. 7: 337.

975 MARINO, Giuseppe. International and European Measures for De-offshoring: Global Ambitions and Local Hypocrisies. Intertax. 45 (2017) No. 8/9: 527.

976 MARTÍNEZ-ESCRIBANO, Celia. Consequences of the European Succession Regulation in European Property Law. European Review of Private Law. 25 (2017) No. 3: 553.

977 MARTÍNEZ-LAGE, Paloma. Galp Energia España: Limitations on the General Court's Unlimited Jurisdiction to Review Decisions Imposing Fines. Journal of European Competition Law and Practice. 7 (2016) No. 9: 608.

978 MARTINIĆ, Stefan; Kozina, Ana. 'Europe 2020' and the EU Public Procurement and State Aid Rules: Good Intentions That Pave a Road to Hell? Croatian Yearbook of European Law and Policy. 12 (2016): 207.

979 MASOUROS, Pavlos; Papadopoulos, Thomas. The Impact of Brexit on UK Company Law. European Company Law. 13 (2016) No. 6: 208.

980 MASTELlONE, Pietro; Giovannelli, Giusto. Recent Competitive Tax and Immigration Measures are Turning Italy into an 'E1 Dorado' for Foreign Investors, Workers and HNWIs. Intertax. 45 (2017) No. 8/9: 577.

981 MAURER, Ludmilla; Port, Christian; Roth, Tom; Walker, John. A Brave New PostBEPS World: New Double Tax Treaty Between Germany and Australia Implements BEPS Measures. Intertax. 45 (2017) No. 4: 310.

982 MAVROGHENIS, Stephen; Griggs, Gabriella. Case AT.40023 Cross-Border Access to Pay-TV: Paramount's Commitments-The Bigger Picture. Journal of European Competition Law and Practice. 8 (2017) No. 8: 499.

983 MCCORMACK, Gerard. Corporate Restructuring Law - a Second Chance for Europe? European Law Review. 42 (2017) No. 4: 532.

984 MCGAUGHEY, Ewan. The Codetermination Bargains: The History of German Corporate and Labor Law. Columbia Journal of European Law. 23 (2016) No. 1: 135.

985 MEDZMARIASHVILI, Megi. Delegation of Rulemaking Power to European Standards Organizations: Reconsidered. Legal Issues of Economic Integration. 44 (2017) No. 4: 353.

986 MEISELlES, Michala; Graute, Marta. The Societas Europaea (SE) - Time to Start Over? Capturing the Zeitgeist of the 21st Century. European Business Law Review. 28 (2017) No. 5: 667.

987 MELlenBerGH, Rik. MiFID II: New Governance and Remuneration Rules in Relation to Investment Firms (Part II). European Company Law. 13 (2016) No. 6: 217.

988 MERIANI, Marianna. Digital Platforms and the Spectrum of Data Protection in Competition Law Analyses. European Competition Law Review. 38 (2017) No. 2: 89.

989 MERIANI, Marianna. The Inextricable Saga of 'Pay for Delay' Cases: The EU Versus the US Approach. European Competition Law Review. 38 (2017) No. 11: 506.

990 MERKX, Madeleine. Fixed Establishments in European Value Added Tax: Base Erosion and Profit Shifting's Side Effects? EC Tax Review. 26 (2017) No. 1: 36. 
$991 \mathrm{MESCH}$, Maria. Exclusive Dealing Agreements within the Scope of the Block Exemption Regulation. European Competition Law Review. 38 (2017) No. 8: 366.

992 METAXAS, Antonis; Spyrou, Smaragda. Alteration of Existing State Aid and New Aid: On the Criteria of This Legal Categorisation Case Law Annotations. European State Aid Law Quarterly. 16 (2017) No. 1: 73.

993 MIKHAYLOVA, Maria; Akhonina, Yulia. Thin Capitalization in Russia: Rules, Trends and Changes. Intertax. 44 (2016) No. 11: 853.

994 MILNE, Janet E. Energy Tax Incentives in the United States: A Comparative Perspective on State Aid Energy and State Aid Control. European State Aid Law Quarterly. 16 (2017) No. 1: 34.

995 MINEO, Léopoldine. The European Union Treatment of Minority Shareholdings Acquisitions. European Competition Law Review. 38 (2017) No. 11: 517.

996 MiTsOPOUlOS, Michael; Pelagidis, Theodore. A Model of Constitutional Design and Corruption. European Journal of Law and Economics. 44 (2017) No. 1: 67.

997 MOLENAAR, Dick. New Options to Restrict Article 17 for Artistes and Sportsmen. Intertax. 44 (2016) No. 12: 972.

998 MOMTAZ, Mahmoud A. The Dual Distribution Discourse: A New Perspective for the Online Hotel Booking Platforms. European Competition Law Review. 38 (2017) No. 4: 171.

999 MONACO, Paola; Venchiarutti, Angelo. Women on Corporate Boards: A Comparative Appraisal of Italian Law. European Business Law Review. 28 (2017) No. 4: 523.

1000 MONTI, Giorgio; Mulder, Jotte. Escaping the Clutches of EU Competition Law. European Law Review. 42 (2017) No. 5: 635.

1001 MORA-SANGUINETTI, Juan S.; Martinez-Matute, Marta. Credit, Crisis and Contract Enforcement: Evidence from the Spanish Loan Market. European Journal of Law and Economics. 44 (2017) No. 2: 361.

1002 MORPHET, Lesley; Hlatshwayo, Nkonzo. South Africa: The Criminalisation of Cartel Conduct. Journal of European Competition Law and Practice. 8 (2017) No. 1: 36.

1003 MOSER, Till; Hentschel, Sven. The Provisions of the EU Anti-Tax Avoidance Directive Regarding Controlled Foreign Company Rules: A Critical Review Based on the Experience with the German CFC Legislation. Intertax. 45 (2017) No. 10: 606 .

1004 MUKWIRI, Jonathan. Directors' and Officers' Insurance in the UK. European Business Law Review. 28 (2017) No. 4: 547.

1005 MUKWIRI, Jonathan. Negotiating Brexit Free Trade Agreements. European Company Law. 14 (2017) No. 1: 5.

1006 MUSATESCU, Virgil; Podasca, Christian; Opris, Ioana. The Romanian State Aid Policy for Promoting Electricity Produced in High Efficiency Cogeneration. European State Aid Law Quarterly. 16 (2017) No. 2: 243.

1007 MWONI NDOLO, Daivd. Is this the End? The Effect of Brexit on the Arbitration of EU Competition Laws in the UK. European Competition Law Review. 38 (2017) No. $7: 322$.

1008 NAKHLA, Michel. Innovative Regulations, Incomplete Contracts and Ownership Structure in the Water Utilities. European Journal of Law and Economics. 42 (2016) No. 3: 445.

1009 NIAZI, Shafi U. Khan. Re-Launch of the Proposal for a Common Consolidated Corporate Tax Base (CCCTB) in the EI: A Shift in Paradigm. Legal Issues of Economic Integration. 44 (2017) No. 3: 293. 
1010 NICOLAIDES, Phedon. A Critical Review of the Commission Notice on the Notion of State Aid. Maastricht Journal of European and Comparative Law. 23 (2016) No. 5: 842 .

1011 NICOLAIDES, Phedon. Excessive Widening of the Concept of Selectivity. European State Aid Law Quarterly. 16 (2017) No. 1: 62.

1012 NICOLAIDES, Phedon. State Aid Rules and Tax Rulings. European State Aid Law Quarterly. 15 (2016) No. 3: 416.

1013 NICOLAIDES, Phedon. What Is the Relevant Price for Determining the Existence of State Aid to Operators and Users of Infrastructure. European State Aid Law Quarterly. 15 (2016) No. 2: 239.

1014 NIESTEN, Hannelore. Case X v. Staatssecretaris van Financiën: Fractional Allocation of Personal and Family Tax Benefits for EU Resident Individuals with Multi-State Income. EC Tax Review. 26 (2017) No. 4: 201.

1015 NIJLAND, J.; Dijkhuizen T.C.A. Say on Pay and Focus on Sustainability of Companies: A Revised Shareholders' Rights Directive. European Company Law. 14 (2017) No. 5: 188.

1016 NOGUEIRA TÔRRES, Adriana. Perspectives of the Concept of Result Regarding Assessment of Municipal Service Tax (ISS) on Exportation of Services: In Brasil. Intertax. 45 (2017) No. 4: 333.

1017 NOUGAYREDE, Delphine. The Use of Offshore Companies in Emerging Market Economies: A Case Study. Columbia Journal of European Law. 23 (2017) No. 2: 401.

1018 NOUWEN, Martijn F. The European Code of Conduct Group Becomes Increasingly Important in the Fight Against Tax Avoidance: More Openness and Transparency is Necessary. Intertax. 45 (2017) No. 2: 138.

1019 NYOMBI, Chrispas. Replacing Lis Pendens with Forum Non Conveniens: A Viable Solution to Tactical Litigation in the EU? European Competition Law Review. 38 (2017) No. 11: 491.

1020 NYOMBI, Chrispas. Tactical Litigation in the Post-Recast Brussels Regulation Era. European Competition Law Review. 38 (2017) No. 10: 457.

1021 ÖBERG, Jacob. The Rise of the Procedural Paradigm: Judicial Review of EU Legislation in Vertical Competence Disputes. European Constitutional Law Review. 13 (2017) No. 2: 248.

1022 OLIVER, Justin; Schoff, Paul. Agency and Competition Law in Australia Following ACCC v Flight Centre Travel Group. Journal of European Competition Law and Practice. 8 (2017) No. 5: 321.

1023 OLIVER, Peter; Stothers, Christopher. Intellectual Property Under the Charter: Are the Court's Scales Properly Calibrated? Common Market Law Review. 54 (2017) No. 2: 517.

1024 O'LOUGHLIN, Peter. Public-Private Antitrust Enforcement Conflicts: Assessing Criminalization as a Solution (Student Note). Columbia Journal of European Law. 23 (2017) No. 3: 683.

1025 OLYKKE, Girth Skovgaard. The Passing-on Defence Catapulted out of State Aid Law Case Law Annotations. European State Aid Law Quarterly. 16 (2017) No. 1: 93.

1026 OLYKKE, Grith Skovgaard. Exclusive Rights and State Aid. European State Aid Law Quarterly. 16 (2017) No. 2: 164.

1027 OLYKKE, Grith Skovgaard. State Aid as Defense for Public Authorities Case Law Annotations. European State Aid Law Quarterly. 15 (2016) No. 2: 286.

1028 OLYKKE, Grith Skovgaard. The Notice of the Notion of State Aid and Public Procurement Law. European State Aid Law Quarterly. 15 (2016) No. 4: 508. 
1029 PAEMEN, Dieter; Baltrusch, Victoria S. Morningstar v Commission: Raising the Threshold for Challenging Commission Commitments Decisions. Journal of European Competition Law and Practice. 8 (2017) No. 2: 99.

1030 PALCHETTI, Paolo. The Allocation of International Responsibility in the Context of Investor-State Dispute Settlement Mechanisms Established by EU International Agreements. European Business Law Review. 28 (2017) No. 2: 185.

1031 PANTALEO, Luca. Investment Disputes under CETA: From Gold Standards to Best Practices? European Business Law Review. 28 (2017) No. 2: 163.

1032 PANTALEO, Luca; Andenas, Mads. Introduction: The European Union as a Global (Legal) Role Model for Trade and Investment? European Business Law Review. 28 (2017) No. 2: 99.

1033 PAOLINI, Dimitri; Pistone, Pasquale; Pulina, Giuseppe. Tax Treaties with Developing Countries and the Allocation of Taxing Rights. European Journal of Law and Economics. 42 (2016) No. 3: 383.

1034 PASTOR-MERCHANTE, Fernando. The Protection of Competitors under State Aid Law. European State Aid Law Quarterly. 15 (2016) No. 4: 527.

1035 PATERSON, Sarah. The Cost of Capital - the Normative Foundation of Corporate Law: A Reply. European Company and Financial Law Review. 14 (2017) No. 2: 316.

1036 PEARCE, Henry. Systems Thinking, Big Data, and Data Protection Law Using Ackoff's Interactive Planning to Respond to Emergent Policy Challenges. European Journal of Law Reform. 18 (2016) No. 4: 478.

1037 PEDONE, Priscille; Thierry Bonnet, Thierry. Mediation in Corporate Disputes in France. European Company Law. 14 (2017) No. 2: 69.

1038 PEDRINI, Giulio. Law and Economics of Training: A Taxonomy of the Main Legal and Institutional Tools Addressing Suboptimal Investments in Human Capital Development. European Journal of Law and Economics. 43 (2017) No. 1: 83.

1039 PEETERS, Bruno. Towards a More Coordinated Approach of the Relation Between the Taxpayer and Tax Administrations: The European Taxpayers' Code. EC Tax Review. 26 (2017) No. 4: 178.

1040 PEETERS, Bruno; Verschueren, Herwig. The Impact of European Union Law on the Interaction of Members States' Sovereign Powers in the Policy Fields of Social Protection and Personal Income Tax Benefits. EC Tax Review. 25 (2016) No. 5/6: 262.

1041 PEETERS, Steven. Exit Taxation: From an Internal Market Barrier to a Tax Avoidance Prevention Tool. EC Tax Review. 26 (2017) No. 3: 122.

1042 PERETZ, George. A Star Is Torn: Brexit and State Aid Opinion. European State Aid Law Quarterly. 15 (2016) No. 3: 334.

1043 PERNAZZA, Federico. Fiat Chrysler Automobiles and the New Face of the Corporate Mobility in Europe. European Company and Financial Law Review. 14 (2017) No. 1: 37.

1044 PETERSEN, Vidir. Interlocking Directorates in the European Union: An Argument for Their Restriction. European Business Law Review. 27 (2016) No. 6: 821.

1045 PETIT, Nicolas. Antitrust and Artificial Intelligence: A Research Agenda. Journal of European Competition Law and Practice. 8 (2017) No. 6: 361.

1046 PETIT, Nicolas. Implications of the Competitive Neutrality Principle for Competition Agencies: A Process Perspective. European Competition Law Review. 38 (2017) No. 11: 501.

1047 PETRUCCI, Carlo. Subsidiarity in Directive 2014/104 EU on Damages Actions for Breach of EU Competition Law. European Public Law. 23 (2017) No. 2: 395. 
1048 PETZOLD, Hans Arno. Airport Selection - New Tools or Loopholes Opened Opinions. European State Aid Law Quarterly. 16 (2017) No. 2: 285.

1049 PHEDON, Nicolaides. What Is Normal. European State Aid Law Quarterly. 16 (2017) No. 2: 146.

1050 PICO, Iván. Towards a Higher Degree of Independence of Competition Authorities: Lessons Learned from Spain's Institutional Reform. European Competition Law Review. 38 (2017) No. 3: 115.

1051 PIERNAS LOPEZ, Juan Jorge. The Evolving Nature of the Notion of Aid under EU Law. European State Aid Law Quarterly. 15 (2016) No. 3: 400.

1052 PINTO, Claudia Saavedra. The Narrow Meaning of the Legitimate Expectation Principle in State Aid Law Versus the Foreign Investor's Legitimage Expectations. European State Aid Law Quarterly. 15 (2016) No. 2: 270.

1053 PIRIM, Ceren Zeynep. A Neverending Story: The Free Movement of Turkish Workers within the European Union. Legal Issues of Economic Integration. 44 (2017) No. 1: 49.

1054 PIRLOT, Alice. The Inadequacy of EU State Aid Law and WTO Law on Subsidies to Regulate Energy Tax Reliefs Energy and State Aid Control. European State Aid Law Quarterly. 16 (2017) No. 1: 25.

1055 PITRUZZELLA, Giovanni. On Vaccines, Pharmaceutical Markets, and a Role for Competition Law in Protecting (also) Human Rights. European Competition Law Review. 38 (2017) No. 8: 347.

1056 PlATTEAU, Koen; Mampaey, Nina. Standard-setting Agreements: The Fine Line Between Legitimate Lobbying Activities And Cartel Behaviour (Belgium). Journal of European Competition Law and Practice. 8 (2017) No. 8: 505.

1057 PlatTeAU, Koen; Mampaey, Nina. Standard-setting Agreements: The Fine Line Between Legitimate Lobbying Activities And Cartel Behaviour (Belgium). Journal of European Competition Law and Practice. 8 (2017) No. 8: 505.

1058 PLAYER, Jane. Mediation of Corporate Disputes in UK. European Company Law. 14 (2017) No. 2: 104.

1059 PLIEGo SELIE, Alvaro A.J.; Brouwer, Onno W. The Commission's State Aid Control over Renewable Energy Stimulation Measures Reinforced. Maastricht Journal of European and Comparative Law. 23 (2016) No. 5: 890.

1060 PODSZUN, Rupprecht. The Digital Economy: Three Chances for Competition Law. Maastricht Journal of European and Comparative Law. 23 (2016) No. 5: 747.

1061 POLLARD, Marcus. Great Expectations-The First Year of Hong Kong's Competition Law Enforcement. Journal of European Competition Law and Practice. 8 (2017) No. 2: 113.

1062 PÖNKÄ, Ville. The Convergence of Law: The Finnish Limited Liability Companies Act as an Example of the So-Called 'Americanization' of European Company Law'. European Company Law. 14 (2017) No. 1: 22.

1063 PORTUESE, Aurelien; Gough, Orla; Tanega, Joseph. The Principle of Legal Certainty as a Principle of Economic Efficiency. European Journal of Law and Economics. 44 (2017) No. 1: 131.

1064 PÖTGENS, Frank; Mergouwen, Mees. The Report Ways to Tackle Cross-Border Obstacles Facing Individuals Within the EU. EC Tax Review. 26 (2017) No. 5: 246.

1065 PREETZ, Friedrich. Does the Notion of Legal Certainty Prohibit an Effects-Based Approach to Rebates? European Competition Law Review. 38 (2017) No. 3: 99.

1066 PURnHAGEN, Kai Peter; Schebesta, Hanna. A Case at the Frontiers of Market Access, Freedom of Goods, the Common Agricultural Policy and Science in 
Court: Reflections on Scotch Whisky Association. European Law Review. 42 (2017) No. 3: 420.

1067 QUINN, John; Connolly, Barry. The Non-Financial Information Directive: An Assessment of Its Impact on Corporate Social Responsibility. European Company Law. 14 (2017) No. 1: 15.

1068 RABINOVICI, Itai. Public Exchange of Information After Container Shipping. Journal of European Competition Law and Practice. 8 (2017) No. 3: 149.

1069 RABINOVICI, Itai. The Application of EU Competition Rules in the Transport Sector. Journal of European Competition Law and Practice. 8 (2017) No. 4: 271.

1070 RAMMELOO, Stephan. A French-German Company Conversion (KG Berlin 21 March 2016): Another Call for Harmonizing the Laws on Cross-Border Company Migrations in Europe. European Company Law. 14 (2017) No. 4: 177.

1071 RANCHORDÁS, Sofia. Consultations, Citizen Narratives and Evidence-Based Regulation. European Journal of Law Reform. 19 (2017) No. 1-2: 52.

1072 REHAHN, Johannes. A Hat That Fits on Different Heads? The Proposed Regulation on Money Market Funds and the System of EU Investment Law. European Company and Financial Law Review. 13 (2016) No. 3: 517.

1073 RIGHINI, Elisabetta; González Fernández, Juan Carlos. Capacity Mechanisms and State Aid: Between PSOS, Market Liberalisation, and Security of Supply. Journal of European Competition Law and Practice. 7 (2016) No. 10: 661.

1074 RINGE, Wolf-Georg. Kornhas and the Challenge of Applying Keck in Establishment. European Law Review. 42 (2017) No. 2: 270.

1075 RITTER. Cyril. How Far Can the Commission Go When Imposing Remedies for Antitrust Infringements? Journal of European Competition Law and Practice. 7 (2016) No. 9: 587.

1076 ROBINS, Nicole; Chakma, Tridevi. State Aid in Energy under the Spotlight: The Implications of the Hinkley Point Decison. European State Aid Law Quarterly. 15 (2016) No. 2: 247.

1077 RODGER, Barry J. Implementation of the Antitrust Damages Directive in the UK: Limited Reform of the Limitation Rules? European Competition Law Review. 38 (2017) No. 5: 219.

1078 RODRIGUEZ, Daniel Perez. Electricity Generation and State Aid: Compatibility Is the Question. European State Aid Law Quarterly. 15 (2016) No. 2: 207.

1079 ROKITA, K. Exclusionary Rebates: Where are We After Post Danmark II and How Did we Get There? European Law Review. 41 (2016) No. 6: 885.

1080 RøNFELDT, Thomas. Comparing Tax Entities in a European Perspective, Part I. Intertax. 44 (2016) No. 12: 938.

1081 RøNFELDT, Thomas. Comparing Tax Entities in a European Perspective, Part II. Intertax. 44 (2016) No. 12: 950.

1082 ROSATI, Eleonora. GS Media and its Implications for the Construction of the Right of Communication to the Public Within EU Copyright Architecture. Common Market Law Review. 54 (2017) No. 4: 1221.

1083 SACCO GINEVRI, Andrea. Staggered Boards, Banks and Public Companies: Quo vadis? European Business Law Review. 28 (2017) No. 4: 575.

1084 SAHIN, Eda. The Cartel of 12 Turkish Banks and Consumer Harm: What Happens Now? European Competition Law Review. 38 (2017) No. 4: 180.

1085 SAINT-ESTEBEN, Robert; Honoré, Pierre. IFP v Commission: Assessment of Public Establishments of an Industrial and Commercial Character Under State Aid Rules. Journal of European Competition Law and Practice. 7 (2016) No. 10: 676. 
1086 SALAZAR V., Roberto R.; Sikora, Spencer. Employees' Say on Pay: Do Works Councils Narrow the CEO-Worker Pay Gap in Germany? European Company Law. 14 (2017) No. 4: 162.

1087 SALVA, Jean-Marie. Customs Valuation and Transfer Pricing: ICC Proposals. EC Tax Review. 25 (2016) No. 5/6: 346.

1088 SAMOL, Katarzyna. The Hybrid Board Model for Japanese Companies: A Model for Other Countries? European Company Law. 13 (2016) No. 6: 210.

1089 SÁNCHEZ-ARCHIDONA HIDALGO, Guillermo. Reflections on Multilateral Tax Solutions in a Post-BEPS Context. Intertax. 45 (2017) No. 11: 714.

1090 SANCHEZ-GRAELLS, Albert. Ski Taxi: Joint Bidding in Procurement as PriceFixing? Journal of European Competition Law and Practice. 8 (2017) No. 7: 451.

1091 SÁNDOR, István. Different Types of Trust from an Ownership Aspect. European Review of Private Law. 24 (2016) No. 6: 1189.

1092 SANKARI, Suvi; Frerichs, Sabine. From Resource to Burden: Rescaling Solidarity with Strangers in the Single Market. European Law Journal. 22 (2016) No. 6: 806.

1093 SANKEY, James. VAT Treatment of Bitcoin: A Proxy for Other Cryptocurrencies: (Skatteverket vs. David Hedqvist, ECJ (Fifth Chamber), Judgment of 22 October 2015, C-264/14). European Law Reporter. (2016) No. 6: 223.

1094 SANTA MARIA, Alberto. Competition and State Aid: An Analysis of the EU Practice. European Competition Law Review. 38 (2017) No. 3: 143.

1095 SCALIA, Roberto. Tax Law Perspective of the 'Cooperation Council for the Arab States of the Gulf' (the 'GCC'). Intertax. 45 (2017) No. 1: 67.

1096 SCHALL, Alexander. The New Law of Piercing the Corporate Veil in the UK. European Company and Financial Law Review. 13 (2016) No. 4: 549.

1097 SCHAMMO, Pierre. Market Building and the Capital Markets Union: Addressing Information Barriers in the SME Funding Market. European Company and Financial Law Review. 14 (2017) No. 2: 271.

1098 SCHIPPERS, Martijn L. Brexit: Consequences for Trade, VAT and Customs: Forum Discussion on the EFS Seminar Held at the Erasmus University Rotterdam on 2 February 2017. EC Tax Review. 26 (2017) No. 4: 220.

1099 SCHMIDT, Karsten. Trust as a Legislative Challenge: Bipolar Relation vs QuasiCorporate Status? Basic Trust Models in Legal Practice, Theory, and Legislation. European Review of Private Law. 24 (2016) No. 6: 995.

1100 SCHOLL, Juliane. Why the New Merger Control Thresholds in Germany? Journal of European Competition Law and Practice. 8 (2017) No. 4: 219.

1101 SCHOLZ, Ulrich; Vohwinkel, Tim. The Application of EU Competition Law in the Energy Sector. Journal of European Competition Law and Practice. 8 (2017) No. 3: 190.

1102 SCHÖNFELD BONN, Jens. CFC Rules and Anti-Tax Avoidance Directive. EC Tax Review. 26 (2017) No. 3: 145.

1103 SCHÖNING, Falk; Dauchez, David. Key Developments in State Aid Law. Journal of European Competition Law and Practice. 8 (2017) No. 2: 126.

1104 SEER, Roman; Wilms, Anna Lena. Tax Transparency in the European Union Regarding Country by Country Reporting (BEPS Action 13). EC Tax Review. 25 (2016) No. 5/6: 325.

1105 SELÇUK ÖZGENÇ, A. Limitation of Benefits Clause and Turkey's Approach: From Policy to Legal Order. Intertax. 45 (2017) No. 5: 417.

1106 SENDEN, Linda. The Constitutional Fit of European Standardization Put to the Test. Legal Issues of Economic Integration. 44 (2017) No. 4: 337. 
1107 SERGAKIS, Konstantinos. The Relevance of Time in Framing the Sanctions Framework for Defective Disclosure. European Business Law Review. 28 (2017) No. 3: 331 .

1108 SETTANI, Giuseppe. Equity Release, Reverse Mortgage and Home Equity Conversion: Perspectives in Different Law Systems and Questions for Harmonization at EU Level. European Business Law Review. 28 (2017) No. 5: 731.

1109 SEWELL, Bruce. In Need of an Economic Reality Check-The Commission's State Aid Decision Regarding Ireland and Apple. Journal of European Competition Law and Practice. 7 (2016) No. 10: 649.

1110 SHARMA, Kamal; Swaroop Das, Anand. A Multidimensional Analysis of the Concept of 'Place of Effective Management' in India: A Panacea to the Double Taxation Conundrum? Intertax. 45 (2017) No. 3: 268.

1111 SHERIDAN, Iain. Smartphones, Research and Development and Corporation Tax: Current Treatment and Future Possibilities. Intertax. 44 (2016) No. 11: 831.

1112 SHROETER, Ulrich; Nemeczek, Heinrich. The (Unclear) Impact of Brexit on the United Kingdom's Membership in the European Economic Area. European Business Law Review. 27 (2016) No. 7: 921.

1113 SICARD, Flora; Debat, Olivier. The EU and Third Countries: Any New Tax Opportunities Under Association Agreements? Intertax. 45 (2017) No. 5: 402.

1114 SIERRA, Jose Luis Buendia. Brexit, a Stress Test for State Aid Control Editorial. European State Aid Law Quarterly. 15 (2016) No. 3: 331.

1115 SILVESTRI, Andrea. Holding Companies in the BEPS Era. Intertax. 45 (2017) No. 6/7: 482 .

1116 SJÖDIN, Cristina. Hutchison 3G Italy/WIND/JV: The Return of Coordinated Effects in EU Merger Control. Journal of European Competition Law and Practice. 8 (2017) No. 2: 105.

1117 SKA, Nathalie; Werner, Philipp; Paul, Christian. Pay-for-Delay Agreements: Why the EU Should Judge Them by Their Effects. Journal of European Competition Law and Practice. 8 (2017) No. 7: 437.

1118 SKAUG, Thea Susanne; Alver, Fredrik; Høegh Krohn Viddal, Magnus. Down the Prohibition Road - An Overview of Norwegian Merger Control and Possible Explanations for Recent Prohibitions. Journal of European Competition Law and Practice. 8 (2017) No. 6: 395.

1119 SKOGSTAD AAMO, Bjørn. Combating Money Laundering and Terrorist Financing: Monitoring the Implementation of FATF Recommendations. European Business Law Review. 28 (2017) No. 1: 89.

1120 SMIT, Daniël S. International Income Allocation under EU Tax Law: Tinker, Tailor, Soldier, Sailor. EC Tax Review. 26 (2017) No. 2: 67.

1121 SMITH, Lionel. The Duties of Trustees in Comparative Perspective. European Review of Private Law. 24 (2016) No. 6: 1031.

1122 SNELL, Jukka; Jaakkola, Jussi. Economic Mobility and Fiscal Federalism: Taxation and European Responses in a Changing Constitutional Context. European Law Journal. 22 (2016) No. 6: 772.

1123 SOLEK, Lukas. Passive Participation in Anticompetitive Agreements. Journal of European Competition Law and Practice. 8 (2017) No. 1: 15.

1124 STAKHEYEVA, Hanna. Distributor's Right to Compensation after Distribution Agreement has Terminated under Laws of Turkey and Germany. European Competition Law Review. 38 (2017) No. 3: 119.

1125 STAKHEYEVA, Hanna. Merger Control in the Big Data World: to be or Not to be Revisited? European Competition Law Review. 38 (2017) No. 6: 265. 
1126 STANCKE, Fabian. Old World Lost-Status and Prospects of the EU Competition Rules for the Insurance Sector after the Expiry of the Insurance BER. Journal of European Competition Law and Practice. 8 (2017) No. 8: 539.

1127 STAVICZKY, Peter. Difficulties to Prove Direct Concern for Competitors of State Aid Beneficiaries Case Law Annotations. European State Aid Law Quarterly. 16 (2017) No. 1: 77.

1128 STAVICZKY, Peter. Granting of State Aid and Effective Communication among Stakeholders. European State Aid Law Quarterly. 15 (2016) No. 2: 235.

1129 STIRLING, Grant. It's a Conspiracy! Or Is It? The Difficulty With the Economic Torts as 'Alternative' Causes of Action for Competition Law Damages Actions in UK Courts. Journal of European Competition Law and Practice. 8 (2017) No. 4: 233.

1130 STONELY, Peter. Is the Price Right? European Business Law Review. 28 (2017) No. 5: 747 .

1131 STRAND, Magnus. Labours of Harmony: Unresolved Issues in Competition Damages. European Competition Law Review. 38 (2017) No. 5: 203.

1132 STRUCKMANN, Kai; Forwood, Genevra; Kadri, Aqeel. Investor-State Arbitrations and EU State Aid Rules: Conflict or Co-Existence. European State Aid Law Quarterly. 15 (2016) No. 2: 258.

1133 STRUCKMANN, Kai; Forwood, Genevra; Kadri, Aqeel; Wallin, Adam. Enforcement of Investor-State Arbitral Awards: More Questions than Answers [Case Law Annotations]. European State Aid Law Quarterly. 16 (2017) No. 2: 316.

1134 STRUMIA, Francesca; Hughes, Mary E. A Momentary Blip or a Step Forward in Revisionist Free Movement?: Case C-308/14 European Commission v. United Kingdom of Great Britain and Northern Ireland (14 June 2016). European Public Law. 23 (2017) No. 4: 723.

1135 STUART, Eugene. Whether or Not to Bite the Apple: Some Implications of the August 2016 Commission Decision on Irish Tax Benefits for Apple. European State Aid Law Quarterly. 16 (2017) No. 2: 209.

1136 SUBIOTTO, Romano; Figus Diaz, Jacopo. Lundbeck v Commission: Reverse Payment Patent Settlements as Restrictions of Competition by Object. Journal of European Competition Law and Practice. 8 (2017) No. 1: 27.

1137 SUBIOTTO, Romano; Little, David R.; Lepetska, Romi. The Application of Article 102 TFEU by the European Commission and the European Courts. Journal of European Competition Law and Practice. 8 (2017) No. 4: 263.

1138 SWADLING, William. Trusts and Ownership: A Common Law Perspective. European Review of Private Law. 24 (2016) No. 6: 951.

1139 SZUDOCZKY, Rita. Convergence of the Analysis of National Tax Measures under the EU State Aid Rules and the Fundamental Freedoms. European State Aid Law Quarterly. 15 (2016) No. 3: 357.

1140 SZYDLO, Marek. The Independence of Data Protection Authorities in EU Law: Between the Safeguarding of Fundamental Rights and Ensuring the Integrity of the Internal Market. European Law Review. 42 (2017) No. 3: 369.

1141 SZYSZCZAK, Erika. Article 263(4) TFEU and the Impossibility of Challenging Recovery Decisions in State Aid Case Law Annotation. European State Aid Law Quarterly. 15 (2016) No. 4: 637.

1142 ŠKRINJAR VIDOVIĆ, Marina. EU Data Protection Reform: Challenges for Cloud Computing. Croatian Yearbook of European Law and Policy. 12 (2016): 171.

1143 TAHENY, Sarah. Case T-95/15 Printeos, SA a.o. v European Commission: First Successful Challenge to a Cartel Settlement Decision. Journal of European Competition Law and Practice. 8 (2017) No. 7: 454. 
1144 TANG, Shin. Second Tobacco Products Directive: Proportionality of Public Health Measures Against Potential Competition Distortions. European Competition Law Review. 38 (2017) No. 1: 1.

1145 TELL, Michael. Interest Limitation Rules in the Post-BEPS Era. Intertax. 45 (2017) No. 11: 750 .

1146 THOMAS, Bastien. The 2015 Orange Settlement Decision: How the French Competition Authority Defines, Addresses, and Remedies Abusive Conduct in the Telecommunications Sector. Journal of European Competition Law and Practice. 8 (2017) No. 3: 172.

1147 TICHÝ, Luboš. Recognition of a Trust as a Specific Problem in Private International Law. European Review of Private Law. 24 (2016) No. 6: 1165.

1148 TORREMANS, Paul. Jurisdiction for Cross-Border Intellectual Property Infringement Cases in Europe. Common Market Law Review. 53 (2016) No. 6: 1625.

1149 TRACANA, Dinis. The Impact of BEPS Actions 8-10 on Comparability Analysis in the Context of Attribution of Profits to Permanent Establishments. Intertax. 45 (2017) No. 5: 411.

1150 TRAVERSA, Edoardo; Pirlot, Alice. The UK Brexit Referendum: A Catalyst to Reform the European Union Institutional Architecture in Tax Matters? Intertax. 44 (2016) No. 12: 878.

1151 TRIAS, Ana. Applying the Principle of Technological Neutrality to State Aid for Network Infrastructures. European State Aid Law Quarterly. 16 (2017) No. 2: 193.

1152 TRIMARCHI, Andrea. EU Regulation 868/2004: Report of a Unilateral Approach on Regulating Unfair Subsidisation and Unfair Pricing Practices and its Failure. European Competition Law Review. 38 (2017) No. 2: 72.

1153 TROUP, Tomáš; Frössel, Andreas. Abuse of Principles of Creditor Autonomy in Insolvency Proceedings. European Review of Private Law. 25 (2017) No. 4: 727.

1154 TSAKANAKIS, Stefan. Significant Restrictions of Competition: Lessons from the Swiss Federal Supreme Court's Decision in Gaba. European Competition Law Review. 38 (2017) No. 10: 437.

1155 VALENTE, Piergiorgio. BEPS Action 15: Release of Multilateral Instrument. Intertax. 45 (2017) No. 3: 219.

1156 VALENTE, Piergiorgio. G7 Priorities in Taxation. Intertax. 45 (2017) No. 8/9: 543.

1157 VALENTE, Piergiorgio: Caraccioli, Ivo. Transfer Pricing Audits: Suitability of Transfer Pricing Documentation. Intertax. 45 (2017) No. 6/7: 501.

1158 VAN ARENDONK, Henk. The European Cooperation Project, Tax \& Sovereignty. EC Tax Review. 25 (2016) No. 5/6: 242.

1159 VAN CALSTER, Geert. Coming, and Here to Stay: The Review of the European Insolvency Regulation. European Business Law Review. 27 (2016) No. 6: 735.

1160 VAN CLEYNENBREUGEL, Pieter. Sharing Powers Within Exclusive Competences: Rethinking EU Antitrust Law Enforcement. Croatian Yearbook of European Law and Policy. 12 (2016): 49.

1161 VAN DE VIJVER, Anne. International Double Taxation in the European Union: Comparative Guidelines from Switzerland and the United States. EC Tax Review. 26 (2017) No. 1: 10.

1162 VAN DEN BREKEL, Ronald; van Doesum, Ad; van Kesteren, Herman. VAT Effects of Year-End Transfer Pricing Adjustments. EC Tax Review. 26 (2017) No. 4: 182.

1163 VAN DER ELST, Christoph. Shareholders Holding the Reins on Remuneration: The European Say on Pay. European Company Law. 14 (2017) No. 3: 114. 
1164 VAN DER ELST, Christoph; Lafarre, Anne. Blockchain and the 21st Century Annual General Meeting. European Company Law. 14 (2017) No. 4: 167.

1165 VAN DER LAAN, Rob. Channel Island Competition Law Enforcement: A New Direction? European Competition Law Review. 38 (2017) No. 6: 295.

1166 VAN DOESUM, Ad; van Kesteren, Herman. Taxes, Duties, Levies and Charges as Part of the Taxable Amount for Value Added Tax. EC Tax Review. 26 (2017) No. 1: 45 .

1167 VAN LEEUWEN, Barend. Rethinking the Structure of Free Movement Law: The Centralisation of Proportionality in the Internal Market. European Journal of Legal Studies. 10 (2017) No. 1: 235 pp.

1168 VAN MEERTEN, Hans; Schmidt, Elmar. Compulsory Membership of Pension Schemes and the Free Movement of Services in the EU. European Journal of Social Security. 19 (2017) No. 2: 118.

1169 VAN OSCH, Pieter. Disclosure of Leniency Documents: Did the Dutch Highest Administrative Court Open Pandora's Box? Journal of European Competition Law and Practice. 7 (2016) No. 10: 682.

1170 VAN SCHAIK, Freya. Timab v Commission: The First Lessons on Hybrid Cartel Settlement Procedures. Journal of European Competition Law and Practice. 8 (2017) No. 5: 309.

1171 VAN VEEN, Wino J.M.; Duin, Hjalmar M.C. Dutch Trusts and Trust-Like Arrangements. European Review of Private Law. 24 (2016) No. 6: 973.

1172 VAN VIJFEIJKEN, Inge J. F. A. One Inheritance, One Tax. EC Tax Review. 26 (2017) No. 4: 214.

1173 VAN VLIET, Hubert. Cousins Material: Right to Intervene in Action for Annulment Against Commission Decision Rejecting Complaint Concerning Articles 101 and 102 TFEU. Journal of European Competition Law and Practice. 8 (2017) No. 7: 451.

1174 VANDENBORRE, Ingrid; Goetz, Thorsten; Kafetzopoulos. Access to File under European Competition Law. Journal of European Competition Law and Practice. 7 (2016) No. 9: 641.

1175 VARJU, Marton; Papp, Mónika. The Crisis, National Economic Particularism and EU Law: What can we Learn from the Hungarian Case? Common Market Law Review. 53 (2016) No. 6: 1647.

1176 VÁZQUEZ CARDEÑOSO, Antonio. State Aid Irrespective of Infringement of Fundamental Freedoms and Recovery Also if Benefit Passed-on to Passengers. Journal of European Competition Law and Practice. 8 (2017) No. 3: 170.

1177 VEGA BORREGO, Félix Alberto. The Special Tax Regimes Clause in the 2016 U.S. Model Income Tax Convention. Intertax. 45 (2017) No. 4: 296.

1178 VELYVYTE, Vilija. The Power to Shape the Internal Market: Implications of CJEU Case Law for the EU's Institutional Balance. Croatian Yearbook of European Law and Policy. 12 (2016): 25.

1179 VELJANOVSKI, Cento. The Law and Economics of Pass-on in Price Fixing Cases. European Competition Law Review. 38 (2017) No. 5: 209.

1180 VERDONK, Tom. Rivalry Among Sports Associations: The Compatibility of Sports Associations' Exclusivity Clauses with EU Competition Law. European Competition Law Review. 38 (2017) No. 2: 80.

1181 VLAHEK, Ana; Damjan, Matija. European Commission's Banking Communication: Question of Validity in the Slovenian Banking Bail-in Puzzle Case Law Annotations. European State Aid Law Quarterly. 15 (2016) No. 3: 458. 
1182 VLEeShOUWERS, Baptist. The Postman Always Rings Twice... on the Application of the Ne Bis In Idem Principle in Competition Law. European Competition Law Review. 38 (2017) No. 7: 305.

1183 VOGEL, Louis. The Recent Application of EU and National Competition Law to Distribution Agreements: Does Competition Law Promote Efficient Distribution Networks? Journal of European Competition Law and Practice. 7 (2016) No. 9: 628.

1184 VOLPIN, Cristina. Protecting the Effectiveness of Leniency Programmes: Applying for Leniency is a Leap in the Dark: DHL Express. Common Market Law Review. 54 (2017) No. 4: 1179.

1185 VON WENDLAND, Bernahard. The Responsible Public Investor and Public MegaProjects Opinions. European State Aid Law Quarterly. 16 (2017) No. 2: 276.

1186 WAISMAN, Agustin. Is the Analysis of SEP Related Injunctions on the Right Track? European Competition Law Review. 38 (2017) No. 1: 39.

1187 WATTEL, Peter J. Stateless Income, State Aid and the (Which?) Arm's Length Principle. Intertax. 44 (2016) No. 11: 791.

1188 WEGENER JESSEN, Pernille. Regulating Competition in the EU. European Competition Law Review. 38 (2017) No. 3: 144.

1189 WEGNER, Anne C.; Oberhammer, Sophie; Berger, Almuth. Recent Competition Law Developments in the Automotive Industry. Journal of European Competition Law and Practice. 7 (2016) No. 10: 696.

1190 WEIDMANN, Oktavia. Beneficial Ownership and Derivatives: Has the Swiss Federal Supreme Court Decision in the SMI Futures Case Put an End to 'CashFutures Arbitrage'? Intertax. 45 (2017) No. 3: 229.

1191 WENINGER, Robert A. The VW Diesel Emissions Scandal and the Spanish Class Action. Columbia Journal of European Law. 23 (2016) No. 1: 91.

1192 WERLAUF, Erik. About 'Restriction', 'Justified' and 'Necessary': A Fairy Tale About Corporate Tax Law and European Union Law from the Home Country of Hans Christian Andersen. European Company Law. 13 (2016) No. 6: 225.

1193 WESSEL, Ramses A.; Takács, Tamara. Constitutional Aspects of the EU's Global Actorness: Increased Exclusivity in Trade and Investment and the Role of the European Parliament. European Business Law Review. 28 (2017) No. 2: 103.

1194 WILKMAN, Folkert. A Decade of Private Enforcement of Intellectual Property Rights under IPR Enforcement Directive 2004/48: Where Do we Stand (and Where Might we Go)? European Law Review. 42 (2017) No. 4: 509.

1195 WINTER, Simon. Symmetric Tax Competition and Lobbying within Federations. European Journal of Political Economy. (2017) No. 49:134.

1196 WISMER, Sebastian; Bongard, Christian; Rasek, Arno. Multi-Sided Market Economics in Competition Law Enforcement. Journal of European Competition Law and Practice. 8 (2017) No. 4: 257.

1197 WOllmanN, Hanno. ARA Foreclosure: A Step Towards 'Consent Decrees' in EU Antitrust Proceedings. Journal of European Competition Law and Practice. 8 (2017) No. 3: 167.

1198 YANG, Yichen. How Far Can the Anti-Monopoly Enforcement Agencies Go When Adopting Commitment Decisions? The Need to Safeguard the Commitment Procedure Under the Chinese Anti-Monopoly Law. Journal of European Competition Law and Practice. 8 (2017) No. 3: 178.

1199 ZEYEN, Gaëtan. When Taxation Meets Arbitration: Recent Initiatives to Introduce and Promote Arbitration in International and European Taxation. Intertax. 45 (2017) No. 11: 722. 
1200 ŽYGIMANTAS, Juška. A More Forceful Collective Redress Schemes in the EU Competition Law. European Journal of Law Reform. 18 (2016) No. 4: 451.

07 Business - Industry - Trade

(Industrial policy / Competitiveness / Enterprise policy / Small and medium-sized enterprises / Corporate social responsibility / Service industries / Financial services / Banks)

1201 ATHANASAKI, Vasiliki. State Aid Rules in the Financial Sector During the Economic Crisis: A Disguised but yet Necessary Retreat or an Honest Compromise? The Case of Greece. European Public Law. 23 (2017) No. 3: 615.

1202 BARTOLACELli, Alessio. Almost Capital-less Companies in Europe: Trends, Variations, Competition. European Company and Financial Law Review. 14 (2017) No. 1: 187.

1203 BUSCH, Danny. Agency and Principal Dealing Under the Markets in Financial Instruments Directive (MiFID) I \& II. European Review of Private Law. 25 (2017) No. 2: 337.

1204 BUSCH, Danny. The Private Law Effect of MiFID: The Genil Case and Beyond. European Review of Contract Law. 13 (2017) No. 1: 70.

1205 CAYTAS, Joanna Diane. Weaponizing Finance: U.S. and European Options, Tools, and Policies (Student Notes). Columbia Journal of European Law. 23 (2017) No. 2: 441.

1206 DAMJANOVIC, Dragana. Territorial Restrictions in the Chimney Sweep Business Under the Services Directive: Hiebler. Common Market Law Review. 54 (2017) No. 5: 1535.

1207 DE MUYNCK, Michiel; Bruloot, Diederik. Credit Intermediation under the 2014 European Mortgage Credit Directive: A Call for Targeted Rules on Intermediary Remuneration. European Review of Contract Law. 13 (2017) No. 1: 1.

1208 ELIANTONIO, Mariolina; Spendzharova, Aneta. The European Union's New 'Better Regulation' Agenda: Between Procedures and Politics. European Journal of Law Reform. 19 (2017) No. 1-2: 3.

1209 GILL-PEDRO, Eduardo. Freedom to Conduct Business in EU Law: Freedom from Interference or Freedom from Domination? European Journal of Legal Studies. 9 (2017) No. 2: 103 pp.

1210 HÄRKÖNEN, Elif. Crowdfunding and the Small Offering Exemption in European and US Prospectus Regulation: Striking a Balance Between Investor Protection and Access to Capital? European Company and Financial Law Review. 14 (2017) No. 1: 121.

1211 HOJNIK, Janja. The Servitization of Industry: EU Law Implications and Challenges. Common Market Law Review. 53 (2016) No. 6: 1575.

1212 HOWARTH, David; Quaglia, Lucia. Brexit and the Single European Financial Market. Journal of Common Market Studies. 55 (2017) No. S1: 149.

1213 HOWELL, Elizabeth. The Evolution of ESMA and Direct Supervision: Are There Implications for EU Supervisory Governance? Common Market Law Review. 54 (2017) No. 4: 1027.

1214 JOHANSEN, Kathrin; Laser, Saskia; Neuberger, Doris. Inside or Outside Control of Banks? Evidence from the Composition of Supervisory Boards. European Journal of Law and Economics. 43 (2017) No. 1: 31.

1215 LAPENTA, Gaetano. Vers un Marché Unique Numérique: Géoblocage et Portabilité Transfrontière des Services de Contenu en Ligne dans 1'UE. European Journal of Legal Studies. 9 (2017) No. 2: 135. 
1216 LEHMANN, Matthias; Ungerer, Johannes. Save the 'Mittelstand': How German Courts Protect Small and Medium-Sized Enterprises from Unfair Terms. European Review of Private Law. 25 (2017) No. 2: 313.

1217 MARIANI, Paola. From Market Fragmentation to Market Integration in the EU Insurance Industry: Can EU Regulation Unify What is Separate at Birth? European Law Review. 42 (2017) No. 5: 657.

1218 MYLLY, Tuomas. Hovering Between Intergovernmentalism and Unionization:the Shape of Unitary Patents. Common Market Law Review. 54 (2017) No. 5: 1381.

1219 NABILOU, Hossein. The Conundrum of Hedge Fund Definition. European Company and Financial Law Review. 14 (2017) No. 1: 149.

1220 NICOLAIDES, Phedon. Extraordinary Public Financial Support for Banks is Not so Extraordinary after All. Maastricht Journal of European and Comparative Law. 24 (2017) No. 3: 343.

1221 PAPACONSTANTINOU, George A. Investment Bankers in Conflict: The Regime of Inducements in MiFID II and the Member States' Struggle for Fairness. European Review of Contract Law. 12 (2016) No. 4: 356.

1222 PARMENTIER, Miriam. Capital Markets Union - One Year On From the Action Plan. European Company and Financial Law Review. 14 (2017) No. 2: 242.

1223 PEARCE, Henry. Systems Thinking, Big Data, and Data Protection Law Using Ackoff's Interactive Planning to Respond to Emergent Policy Challenges. European Journal of Law Reform. 18 (2016) No. 4: 478.

1224 PERNAZZA, Federico. Fiat Chrysler Automobiles and the New Face of the Corporate Mobility in Europe. European Company and Financial Law Review. 14 (2017) No. 1: 37.

1225 REHAHN, Johannes. A Hat That Fits on Different Heads? The Proposed Regulation on Money Market Funds and the System of EU Investment Law. European Company and Financial Law Review. 13 (2016) No. 3: 517.

1226 ROSE, Caspar. The Relationship between Corporate Governance Characteristics and Credit Risk Exposure in Banks: Implications for Financial Regulation. European Journal of Law and Economics. 43 (2017) No. 1: 167.

1227 SAHIN, Eda. The Cartel of 12 Turkish Banks and Consumer Harm: What Happens Now? European Competition Law Review. 38 (2017) No. 4: 180.

1228 SPENDZHAROVA, Aneta; Radulova, Elissaveta; Surala, Kate. Get Your Money's Worth from Investment Advice. European Journal of Law Reform. 19 (2017) No. 1-2: 34.

1229 TUOMINEN, Tomi. The European Banking Union:a Shift in the Internal Market Paradigm? Common Market Law Review. 54 (2017) No. 5: 1359.

1230 VAN GULIJK, Stéphanie. Contractual Networks in Construction Services: A Dutch Building Block? European Review of Private Law. 25 (2017) No. 5: 859.

1231 WOODHOUSE, Andrew. The Internal Market and National Security: Transposition, Impact and Reform of the EU Directive on Intra-Community Transfers of Defence Products. Common Market Law Review. 54 (2017) No. 2: 403.

08 Employment - Labour market

(Social dialogue / Working conditions / Local employment initiatives / Health and safety at work / Trade unions)

1232 ABRUNHOSA E SOUSA, Duarte. Work-Life Balance and the Economic Crisis. Some Insights from the Perspectives of Comparative Law Book Review. European Labour Law Journal. 8 (2017) No. 1: 105. 
1233 ADAMS, Zoe; Bastani, Parisa; Bishop Louise; Deakin, Simon. The CBR-LRI Dataset: Methods, Properties and Potential of Leximetric Coding of Labour Laws. International Journal of Comparative Labour Law and Industrial Relations. 33 (2017) No. 1: 59 .

1234 ALES, Edoardo. The European Employment Strategy as Enhanced Coordination: A Holistic Approach to the EU Social Commitment. European Labour Law Journal. 8 (2017) No. 2: 122.

1235 ALES, Edoardo; Bazzani, Tania. The European Employment Strategy Twenty Years on: Risks, Challenges and Opportunities. European Labour Law Journal. 8 (2017) No. 2: 109

1236 ALIDADI, Katayoun. Religion and Unemployment Benefits: Comparing Belgium, the Netherlands and Great Britain Academic Contributions. European Labour Law Journal. 8 (2017) No. 1: 67.

1237 ANTONAKI, Ilektra. Collective Redundancies in Greece: AGET Iraklis. Common Market Law Review. 54 (2017) No. 5: 1513.

1238 AUTEnNE, Alexia. Occupational Pension Funds Governance Issues at the International and European Levels. European Journal of Social Security. 19 (2017) No. 2: 158 .

1239 BARRETT, Gavin. Contract or Code? Determining the Reach of European Union Employment Law and the Effect of Flags of Convenience: Stroumpoulis. Common Market Law Review. 54 (2017) No. 3: 921.

1240 BAZZANI, Tania. Italy, Denmark and Germany: A Comparative Analysis in Active and Passive Labour Market Policies. European Labour Law Journal. 8 (2017) No. 2: 133 .

1241 BEETHÄUSER, Bastian. Protecting Outsiders? Corporatism and the Dualisation of Unemployment Protection in Germany and Austria. European Journal of Social Security. 19 (2017) No. 3: 209.

1242 BERNACIAK, Magdalena; Lis, Aleksandra. Weak Labour, Strong Interests: Polish Trade Unions and the Integration of EU Energy and Service Markets. Journal of Common Market Studies. 55 (2017) No. 3: 432.

1243 BIJ DE VAATE, Vivian. Achieving Flexibility and Legal Certainty through Procedural Dismissal Law Reforms: The German, Italian, and Dutch Solutions Academic Contributions. European Labour Law Journal. 8 (2017) No. 1: 5.

1244 BOGG, Alan. Labour, Love and Futility: Philosophical Perspectives on Labour Law. International Journal of Comparative Labour Law and Industrial Relations. 33 (2017) No. 1: 7 .

1245 BOGG, Alan. Republican Non-Domination and Labour Law: New Normativity or Trojan Horse? International Journal of Comparative Labour Law and Industrial Relations. 33 (2017) No. 3: 391.

1246 BREEN, Keith. Non-Domination, Workplace Republicanism, and the Justification of Worker Voice and Control. International Journal of Comparative Labour Law and Industrial Relations. 33 (2017) No. 3: 419.

1247 CABRELLI, David; Zahn, Rebecca. Theories of Domination and Labour Law: An Alternative Conception for Intervention? International Journal of Comparative Labour Law and Industrial Relations. 33 (2017) No. 3: 339.

1248 CAGNIN, Valentina. Investor-State Dispute Settlement (ISDS) from a Labour Law Perspective. European Labour Law Journal. 8 (2017) No. 3: 217.

1249 CONAGHAN, Joanne. Labour Law and Feminist Method. International Journal of Comparative Labour Law and Industrial Relations. 33 (2017) No. 1: 93. 
1250 CONCHON, Aline; Triangle, Luc. Industriall European Trade Union: Over 20 years of Working with European Works Councils. European Journal of Industrial Relations. 23 (2017) No. 3: 309.

1251 COSTAMAgnA, Francesco. Minimum Wage between Public Procurement and Posted Workers: Anything New after the RegioPost case? European Law Review. 42 (2017) No. 1: 101.

1252 DAHAN, Yossi; Lerner, Hanna; Milman-Sivan, Faina. The Guiding Principles for Business and Human Rights: Labour Violations and Shared Responsibility. International Journal of Comparative Labour Law and Industrial Relations. 32 (2016) No. 4: 425.

1253 DAVIDOV, Guy. Subordination vs Domination: Exploring the Differences. International Journal of Comparative Labour Law and Industrial Relations. 33 (2017) No. 3: 365 .

1254 DE SPIEGELAERE, Stan; Waddington, Jeremy. Has the Recast Made a Difference? An Examination of the Content of European Works Council Agreements. European Journal of Industrial Relations. 23 (2017) No. 3: 293.

1255 DEGOLI, Maria-Christina. Free Movement of Workers and the RESAVER Scheme for Researchers. European Journal of Social Security. 19 (2017) No. 2: 172.

1256 DEL PUNTA, Ricardo. Labour Law and the Capability Approach. International Journal of Comparative Labour Law and Industrial Relations. 32 (2016) No. 4: 383.

1257 DEL SOL, Marion; Rocca, Marco. Free Movement of Workers in the EU and Occupational Pensions Conflicting Priorities? Between Case Law and Legislative Interventions. European Journal of Social Security. 19 (2017) No. 2: 141.

1258 DUVAL, Antoine; van Maren, Oskar. The Labour Status of Professional Football Players in the European Union Unity in/and/or Diversity? European Labour Law Journal. 8 (2017) No. 3: 258.

1259 EBERHARTINGER, Eva; Petutschnig, Matthias. CCCTB: The Employment Factor Game. European Journal of Law and Economics. 43 (2017) No. 2: 333.

1260 EBERT, Franz Christian. The Comprehensive Economic and Trade Agreement (CETA): Are Existing Arrangements Sufficient to Prevent Adverse Effects on Labour Standards? International Journal of Comparative Labour Law and Industrial Relations. 33 (2017) No. 2: 295.

1261 ESPINOSA, Romain; Desrieux, Claudine; Wan, Hengrui. Fewer Courts, Less Justice? Evidence from the 2008 French Reform of Labor Courts. European Journal of Law and Economics. 43 (2017) No. 2: 195.

1262 FÖHRER, Bianca; Erne, Roland. Training Programmes for European Works Councillors in Germany, in Ireland and at EU Level: Transnational Trade Union Action Through Education? European Journal of Industrial Relations. 23 (2017) No. 3: 243.

1263 FORD, Michael. The Impact of Brexit on UK Labour Law. International Journal of Comparative Labour Law and Industrial Relations. 32 (2016) No. 4: 473.

1264 FRISCHL, Richard Michael. Teaching Law as a Vocation: Local 1330, Promissory Estoppel, and the Critical Tradition in Labour Scholarship. International Journal of Comparative Labour Law and Industrial Relations. 33 (2017) No. 1: 145.

1265 FROMAGE, Diane; Kreilinger, Valentin. National Parliaments' Third Yellow Card and the Struggle over the Revision of the Posted Workers Directive. European Journal of Legal Studies. 10 (2017) No. 1: 125 pp.

1266 GALlEGO, Aina; Marx, Paul. Multi-Dimensional Preferences for Labour Market Reforms: A Conjoint Experiment. Journal of European Public Policy. 24 (2017) No. 7: 1027. 
1267 GOEBEL, Roger J. Adding a Little Gold to the Golden Years: Should the European Union Prohibit Compulsory Retirement as Age-Based Discrimination in Employment. Columbia Journal of European Law. 23 (2017) No. 2: 305.

1268 HANN, Deborah; Hauptmeier, Marco; Waddington, Jeremy. European Works Councils after Two Decades. European Journal of Industrial Relations. 23 (2017) No. 3: 209.

1269 HAŠKOVÁ, Hana; Dudová, Radka. Precarious Work and Care Responsibilities in the Economic Crisis. European Journal of Industrial Relations. 23 (2017) No. 1: 47.

1270 HEGGEBØ, Kristian. Hiring, Employment, and Health in Scandinavia: The Danish 'Flexicurity' Model in Comparative Perspective. European Societies. 18 (2016) No. 5: 460.

1271 HINZ, Sarah; Morris, Jeremy. Trade Unions in Transnational Automotive Companies in Russia and Slovakia: Prospects for Working-Class Power. European Journal of Industrial Relations. 23 (2017) No. 1: 97.

1272 IVLEVS, Artjoms; Veliziotis, Michail. What Do Unions Do in Times of Economic Crisis? Evidence from Central and Eastern Europe. European Journal of Industrial Relations. 23 (2017) No. 1: 81.

1273 JENSEN, Per H.; Juul Møberg, Rasmus. Does Women's Employment Enhance Women's Citizenship? European Societies. 19 (2017) No. 2: 178.

1274 JENSEN, Per H.; Juul Møberg, Rasmus; Och, Ralf; Pfau-Effinger, Birgit. Explaining Differences in Women's Working Time in European Cities. European Societies. 19 (2017) No. 2: 138 .

1275 JØRGEN, Svalund; Saloniemi, Antti; Vulkan, Patrik. Attitudes Towards Job Protection Legislation: Comparing Insiders and Outsiders in Finland, Norway and Sweden. European Journal of Industrial Relations. 22 (2016) No. 4: 371.

1276 KAMANABROU, Sudabeh. Successful Rules on Successive Fixed-Term Contracts? International Journal of Comparative Labour Law and Industrial Relations. 33 (2017) No. 2: 221.

1277 KASEARU, Kairi; Maestripieri, Lara; Ranci, Constanzo. Women at Risk: The Impact of Labour-Market Participation, Education and Household Structure on the Economic Vulnerability of Women through Europe. European Societies. 19 (2017) No. 2: 202.

1278 KERCKHOFS, Peter. Collective Interest Representation of the European Workforce in European Works Councils. European Journal of Industrial Relations. 23 (2017) No. 3: 277.

1279 KORKUT, Umut [et al.]. What Next for Unions in Central and Eastern Europe? Invisibility, Departure and the Transformation of Industrial Relations. European Journal of Industrial Relations. 23 (2017) No. 1: 65.

1280 KRAMER, Dion. From Worker to Self-Entrepreneur: The Transformation of Homo Economicus and the Freedom of Movement in the European Union. European Law Journal. 23 (2017) No. 3-4: 172.

1281 KRÜGER, Laura. Temporary Agency Workers Work 'Temporarily': A European and German Interpretation of the Notion 'Temporarily'. European Labour Law Journal. 7 (2016) No. 4: 576.

1282 LANGILLE, Brian. 'Hard Law Makes Bad Cases': The International Labour Organization (Nervously) Confronts New Governance Institutions. International Journal of Comparative Labour Law and Industrial Relations. 32 (2016) No. 4: 407.

1283 LHERNOULD, Jean-Philippe; Palli, Barbara. Posted Workers Remuneration: Comparative Study in Nine EU Countries and Four Sectors. Maastricht Journal of European and Comparative Law. 24 (2017) No. 1: 108. 
1284 LISSOWSKA, Maria. The Financial Crisis and Changing Labour Markets in PostTransition Countries. European Journal of Industrial Relations. 23 (2017) No. 1: 17.

1285 MÄHLMEYER, Valentina; Rampeltshammer, Luitpold;Hertwig, Markus. European Works Councils During the Financial and Economic Crisis: Activation, Stagnation or Disintegration? European Journal of Industrial Relations. 23 (2017) No. 3: 225 .

1286 MCGAUGHEY, Ewan. The Codetermination Bargains: The History of German Corporate and Labor Law. Columbia Journal of European Law. 23 (2016) No. 1: 135.

1287 MEDLAND, Lydia. Misconceiving 'Seasons' in Global Food Systems: The Case of the EU Seasonal Workers Directive. European Law Journal. 23 (2017) No. 3-4: 157.

1288 MENEGATTI, Emanuele. Challenging the EU Downward Pressure on National Wage Policy. International Journal of Comparative Labour Law and Industrial Relations. 33 (2017) No. 2: 195.

1289 MULDER, Bernard Johann. The Law Concerning the Election of Employees' Representatives in Company Bodies Critical Note. European Labour Law Journal. 8 (2017) No. 1: 96.

1290 NAVEED, Amjad; Javakhishvili-Larsen, Nino; Dall Schmidt, Torben. Labour Mobility and Local Employment: Building a Local Employment Base from Labour Mobility? Regional Studies. 51 (2017) No. 11: 1622.

1291 O'CONNOR, Niall. Interpreting Employment Legislation through a Fundamental Rights Lens: What's the Purpose? European Labour Law Journal. 8 (2017) No. 3: 193.

1292 PAPADOPOULOS, Orestis. Economic Crisis and Youth Unemployment: Comparing Greece and Ireland. European Journal of Industrial Relations. 22 (2016) No. 4: 409.

1293 PIETROGOVANNI, Vincenzo; Iossa, Andrea. Workers' Representation and Labour Conflict at Company Level: The Italian Binary Star in the Prism of the Swedish Ternary System Academic Contributions. European Labour Law Journal. 8 (2017) No. 1: 45 .

1294 PROSSER, Thomas. Explaining Implementation through Varieties of Capitalism Theory: The Case of the Telework and Work-related Stress Agreements. Journal of Common Market Studies. 55 (2017) No. 4: 889.

1295 PROSSER, Thomas. Insiders and Outsiders on a European Scale. European Journal of Industrial Relations. 23 (2017) No. 2: 135.

1296 PULIGNANO, Valeria. Articulation within (and Across) Transnational Workplaces and the Role of European Works Councils. European Journal of Industrial Relations. 23 (2017) No. 3: 261.

1297 RAMMELOO, Stephan. From Rome to Rome - Cross-Border Employment Contract (Case Note). Maastricht Journal of European and Comparative Law. 24 (2017) No. 2: 298.

1298 REGAN, Aidan. Rethinking Social Pacts in Europe: Prime Ministerial Power in Ireland and Italy. European Journal of Industrial Relations. 23 (2017) No. 2: 117.

1299 RISAK, Martin; Kovács, Erika. Active and Passive Labour Market Policies in Austria and Hungary: A Comparative Analysis of Recent Changes and Trends. European Labour Law Journal. 8 (2017) No. 2: 168.

1300 SCHIEK, Dagmar. Comparing Labour Laws in the EU Internal Market: A Social Actor Perspective. International Journal of Comparative Labour Law and Industrial Relations. 33 (2017) No. 1: 171.

1301 SCHMITT, Carina; Starke, Peter. The Political Economy of Early Exit: The Politics of Cost-Shifting. European Journal of Industrial Relations. 22 (2016) No. 4: 391. 
1302 SCHWAB, Stewart J. Law-and-Economics Approaches to Labour and Employment Law. International Journal of Comparative Labour Law and Industrial Relations. 33 (2017) No. 1: 115.

1303 SJÖBERG, Ola. Employee Collective Voice and Short-Term Sickness Absence in Europe. European Journal of Industrial Relations. 23 (2017) No. 2: 151.

1304 SOULSBY, Anna; Hollinshead, Graham; Steger, Thomas. Crisis and Change in Industrial Relations in Central and Eastern Europe. European Journal of Industrial Relations. 23 (2017) No. 1: 5.

1305 SOUSA MACHADO, Susana. Religious Freedom and Labour Relationships in Portugal: From Abstention to Positive Practice of Accommodation. European Labour Law Journal. 7 (2016) No. 4: 589.

1306 SOUTO-OTERO, Manuel; Shields, Robin. The Investment Model of Volunteering in the EU-27 Countries: Volunteering, Skills Development and Employability. A Multi-Level Analysis. European Societies. 18 (2016) No. 5: 487.

1307 SOWERY, Katy. Equivalent Treatment of Union Rights under National Procedural Law: Târsia. Common Market Law Review. 53 (2016) No. 6: 1705.

1308 THOMAS, Adrien. The Transnational Circulation of the 'Organizing Model' and its Reception in Germany and France. European Journal of Industrial Relations. 22 (2016) No. 4: 317.

1309 THOMSEN, Steen; Rose, Caspar; Kronborg, Dorte. Employee Representation and Board Size in the Nordic Countries. European Journal of Law and Economics. 42 (2016) No. 3: 471.

1310 TODOLÍ-SIGNES, Adrián. The End of the Subordinate Worker? The On-Demand Economy, the Gig Economy, and the Need for Protection for Crowdworkers. International Journal of Comparative Labour Law and Industrial Relations. 33 (2017) No. 2: 241.

1311 TUCKER, Eric. On Writing Labour Law History: A Reconnaissance. International Journal of Comparative Labour Law and Industrial Relations. 33 (2017) No. 1: 39.

1312 TURUNEN, Teemu; Nätti, Jouko. The Effects of Employee and Country Characteristics on Employment Commitment in Europe. European Societies. 19 (2017) No. 3: 313.

1313 VAN DER MEI, Anne Pieter. Collective Redundancies: Judicial Fine-Tuning of a Classic Concept of EU Labour Law. European Law Review. 42 (2017) No. 1: 82.

1314 VAN GULIJK, Stéphanie. Contractual Networks in Construction Services: A Dutch Building Block? European Review of Private Law. 25 (2017) No. 5: 859.

1315 VICKERS, Lucy. Achbita and Bougnaoui One Step Forward and Two Steps Back for Religious Diversity in the Workplace. European Labour Law Journal. 8 (2017) No. 3: 232.

1316 WAAS, Bernard. What Role for Solopreneurs in the Labour Market? European Labour Law Journal. 8 (2017) No. 2: 154.

1317 WAGNER, Ines; Refslund, Bjarke. Understanding the Diverging Trajectories of Slaughterhouse Work in Denmark and Germany: A Power Resource Approach. European Journal of Industrial Relations. 22 (2016) No. 4: 335.

1318 WEISS, Manfred. European Employment Policies A Critical Analysis of the Legal Framework. European Labour Law Journal. 8 (2017) No. 2: 111.

1319 WILSON, Shaun; Hadler, Markus. Downward Flexibility: Who is Willing to Take an Inferior Job? European Journal of Industrial Relations. 23 (2017) No. 2: 187.

1320 WIß, Tobias. Employee Representatives' Influence on Continuing Vocational Training: The Impact of Institutional Context. European Journal of Industrial Relations. 23 (2017) No. 2: 169. 
1321 ZARTALOUDIS, Sotirios; Kornelakis, Andreas. Flexicurity between Europeanization and Varieties of Capitalism? A Comparative Analysis of Employment Protection Reforms in Portugal and Greece. Journal of Common Market Studies. 55 (2017) No. 5: 1144 .

1322 ZBYSZEWSKA, Ania. Active Aging through Employment: A Critical Feminist Perspective on Polish Policy. International Journal of Comparative Labour Law and Industrial Relations. 32 (2016) No. 4: 449.

1323 ZEKIC, Nuna. Job Security or Employment Security: What's in a Name? European Labour Law Journal. 7 (2016) No. 4: 548.

1324 ZILTENER, Patrick; Gabathuler, Heinz. Swiss Multinational Companies and their European Works Councils: European Voluntarism Meets Swiss Voluntarism. European Journal of Industrial Relations. 22 (2016) No. 4: 353.

1325 ZOETEWEIJ-TURHAN, Margarite Helena. The Seasonal Workers Directive: But Some Are More Equal than Others Academic Contributions. European Labour Law Journal. 8 (2017) No. 1: 28.

09 Social policy - Social issues

(Social security / Social protection / Gender equality / Disability issues / Health / Drugs / Tobacco / Communicable diseases / The young / The family / The elderly)

1326 AASEN, Henriette Sinding; Hartlev, Mette; Magnussen, Anne-Mette. Right to Hospital Care and Prioritisation from a Law and Politics Perspective - The Experiences of Norway and Denmark. European Journal of Social Security. 18 (2016) No. 4: 409.

1327 ALANKO, Anna; Outinen, Sami. Dualising Activation. Responses to Unemployment and Mental Health-Related Disability Retirement in Finland at the Turn of the Millennium. European Societies. 18 (2016) No. 5: 417.

1328 ARTETXE, Simon Lopez. Is Health Really the First Thing in Life [Case Review]. Legal Issues of Economic Integration. 44 (2017) No. 3: 315.

1329 ARUNDEL, Rowan; Lennartz, Christian. Returning to the Parental Home: Boomerang Moves of Younger Adults and the Welfare Regime Context. Journal of European Social Policy. 27 (2017) No. 3: 276.

1330 AVRAM, Silvia. Social Assistance Performance in Central and Eastern Europe: A Pre-Transfer Post-Transfer Comparison. Journal of European Social Policy. 26 (2016) No. 5: 428.

1331 BABAYEV, Rufat. Re Shaping the Paradigm of Social Solidarity in the EU: On the UK's Welfare Reforms and Pre- and Post-EU Referendum Developments. European Journal of Social Security. 18 (2016) No. 4: 356.

1332 BAETEN, Rita; Vanhercke, Bart. Inside the Black Box: The EU's Economic Surveillance of National Healthcare Systems. Comparative European Politics. 15 (2017) No. 3: 478.

1333 BANYÁR, József. European Handling of Implicit and Explicit Government Debt as an Obstacle to the Funding-Type Pension Reforms. European Journal of Social Security. 19 (2017) No. 1: 45.

1334 BENNETT, Jenny. Skill-Specific Unemployment Risks: Employment Protection and Technological Progress - A Cross-National Comparison. Journal of European Social Policy. 26 (2016) No. 5: 402.

1335 Blomgren, Jenni; Maunula, Nico; Hiilamo, Heikki. Do Debts Lead to Disability Pension? Evidence from a 15-year Follow-up of 54,000 Finnish Men and Women. Journal of European Social Policy. 27 (2017) No. 2: 109. 
1336 BORGNA, Camilla. Different Systems, Same Inequalities? Post-Compulsory Education and Young Adults' Literacy in 18 OECD Countries. Journal of European Social Policy. 27 (2017) No. 4: 332.

1337 BOZZANO, Monica. On the Historical Roots of Women's Empowerment across Italian Provinces: Religion or Family Culture? European Journal of Political Economy. (2017) No. 49: 24.

1338 BRACKE, Sietse; Mulier, Klaas. Making Divorce Easier: The Role of No-Fault and Unilateral Revisited. European Journal of Law and Economics. 43 (2017) No. 2: 239.

1339 BREIDAHL, Karen N.; Albrekt Larsen, Christian. The Myth of Unadaptable Gender Roles: Attitudes towards Women's Paid Work among Immigrants across 30 European Countries. Journal of European Social Policy. 26 (2016) No. 5: 387.

1340 BRZINSKY-FAY, Christian. The Interplay of Educational and Labour Market Institutions and Links to Relative Youth Unemployment. Journal of European Social Policy. 27 (2017) No. 4: 346.

1341 BUSEMEYER, Marius R.; Garritzmann, Julian L. Academic, Vocational or General? An Analysis of Public Opinion towards Education Policies with Evidence from a New Comparative Survey. Journal of European Social Policy. 27 (2017) No. 4: 373.

1342 BUSEMEYER, Marius R.; Garritzmann, Julian L. Public Opinion on Policy and Budgetary Trade-Offs in European Welfare States: Evidence from a New Comparative Survey. Journal of European Public Policy. 24 (2017) No. 6: 871.

1343 BUSEMEYER, Marius R.; Neimanns, Erik. Conflictive Preferences towards Social Investments and Transfers in Mature Welfare States: The Cases of Unemployment Benefits and Childcare Provision. Journal of European Social Policy. 27 (2017) No. 3: 229.

1344 CAMPILLO, Inés; Armijo, Lorena. Lifestyle Preferences and Strategies of Spanish Working Mothers: A Matter of Choice? South European Society and Politics. 22 (2017) No. 1: 81.

1345 CANTILlON, Bea; Marchal, Sarah; Luigjes, Chris. Decent Incomes for the Poor: Which Role for Europe? Journal of Common Market Studies. 55 (2017) No. 2: 240.

1346 CARMEL, Emma. Re-interpreting Knowledge, Expertise and EU Governance: The Cases of Social Policy and Security Research Policy. Comparative European Politics. 15 (2017) No. 5: 771.

1347 CHOU, Yueh-Ching [et al.]. Impact of Care Responsibilities on Women's Employment: A Comparison between European and East Asian Welfare States. European Societies. 19 (2017) No. 2: 157.

1348 CHUNG, Heejung; Meuleman, Bart. European Parents' Attitudes towards Public Childcare Provision: The Role of Current Provisions, Interests and Ideologies. European Societies. 19 (2017) No. 1: 49.

1349 CHZHEN, Yekaterina. Unemployment, Social Protection Spending and Child Poverty in the European Union during the Great Recession. Journal of European Social Policy. 27 (2017) No. 2: 123.

1350 CRAVEIRO, Daniela. Ties and Inequalities in Later Life: Welfare State Regime and the Role of Social Networks in Health Inequalities in Later Life in Europe. European Societies. 19 (2017) No. 3: 268.

1351 DE LA PORTE, Caroline; Emmenegger, Patrick. The Court of Justice of the European Union and Fixed-Term Work: Putting a Brake on Labour Market Dualization? Journal of European Social Policy. 27 (2017) No. 3: 295.

1352 DE RUIJTER, Anniek. Mapping the Institutional Consolidation of EU Human Health Expertise. Comparative European Politics. 15 (2017) No. 3: 370. 
1353 DE TORRES PEREA, José Manuel. Das Kindeswohl im spanischen Familienrecht. Eine vergleichende Analyse mit dem US-Recht. European Review of Private Law. 25 (2017) No. 1: 3.

1354 DE VIDO, Sara. The Ratification of the Council of Europe Istanbul Convention by the EU: A Step Forward in the Protection of Women from Violence in the European Legal System. European Journal of Legal Studies. 9 (2017) No. 2: 69 pp.

1355 DI STASIO, Valentina. 'Diversion or Safety Net?' Institutions and Public Opinion on Vocational Education and Training. Journal of European Social Policy. 27 (2017) No. 4: 360.

1356 DI STASIO, Valentina; Solga, Heike. Education as Social Policy: An Introduction. Journal of European Social Policy. 27 (2017) No. 4: 313.

1357 ENNSER-JEDENASTIK, Laurenz. Campaigning on the Welfare State: The Impact of Gender and Gender Diversity. Journal of European Social Policy. 27 (2017) No. 3: 215.

1358 ESMARK, Anders; Schoop, Sarah R. Deserving Social Benefits? Political Framing and Media Framing of 'Deservingness' in Two Welfare Reforms in Denmark. Journal of European Social Policy. 27 (2017) No. 5: 417.

1359 FERREIRA, Nuno. Working Children in Europe: A Socio-Legal Approach to the Regulation of Child Work. European Journal of Comparative Law and Governance. 4 (2017) No. 1: 43 pp.

1360 FERRERA, Maurizio. The Contentious Politics of Hospitality: Intra-EU Mobility and Social Rights. European Law Journal. 22 (2016) No. 6: 791.

1361 FISCHER, Mirjam M.; Kalmijn, Matthijs; Steinmetz, Stephanie. Does Tolerance Matter? A Comparative Study of Well-Being of Persons in Same-Sex and MixedSex Unions across Nine European Countries. European Societies. 18 (2016) No. 5: 514.

1362 FLYNN, Lindsay. Childcare Markets and Maternal Employment: A Typology. Journal of European Social Policy. 27 (2017) No. 3: 260.

1363 FORSLUND, Maria. The State of Dying. Mortality in a Comparative Perspective - the Interplay between Cash and Care. European Journal of Social Security. 19 (2017) No. 1: 4.

1364 FOUBERT, Petra. Child Care Leave 2.0 - Suggestions for the Improvement of the EU Maternity and Parental Leave Directives from a Rights Perspective. Maastricht Journal of European and Comparative Law. 24 (2017) No. 2: 245.

1365 FRAILE, Marta; Gomez, Raul. Bridging the Enduring Gender Gap in Political Interest in Europe: The Relevance of Promoting Gender Equality. European Journal of Political Research. 56 (2017) No. 3: 601.

1366 FRENCH, Declan; McKilop, Donal. The Impact of Debt and Financial Stress on Health in Northern Irish Households. Journal of European Social Policy. 27 (2017) No. 5: 458 .

1367 GAMBARO, Ludovica. Who is Minding the Kids? New Developments and Lost Opportunities in Reforming the British Early Education Workforce. Journal of European Social Policy. 27 (2017) No. 4: 320.

1368 GOEBEL, Roger J. Adding a Little Gold to the Golden Years: Should the European Union Prohibit Compulsory Retirement as Age-Based Discrimination in Employment. Columbia Journal of European Law. 23 (2017) No. 2: 305.

1369 GREER, Scott L,; Löblová, Olga. European Integration in the Era of Permissive Dissensus: Neofunctionalism and Agenda-Setting in European Health Zechnology Assessment and Communicable Disease Control. Comparative European Politics. 15 (2017) No. 3: 394. 
1370 GUETTO, Raffaele; Vergolini, Loris. Educational Expansion without Equalization: A Reappraisal of the 'Effectively Maintained Inequality' Hypothesis in Children's Choice of the Upper Secondary Track. European Societies. 19 (2017) No. 1: 1.

1371 HANSEN, Ole. Public Law by Contract: The Reluctant Creation of Private Markets for Welfare Service. European Review of Private Law. 25 (2017) No. 3: 619.

1372 HENDRICXX, Frank. The European Pillar of Social Rights: Interesting Times Ahead. European Labour Law Journal. 8 (2017) No. 3: 191.

1373 HERVEY, Tamara K. Telling Stories about European Union Health Law: The Emergence of a New Field of Law. Comparative European Politics. 15 (2017) No. 3: 352 .

1374 HOPPANIA, Hanna-Kaisa; Mäkki-Petäjä-Leinonen, Anna; Nikumma, Henna. (Un) equal Treatment? Elderly Care and Disability Services for People with Dementia in Finland. European Journal of Social Security. 19 (2017) No. 3: 225.

1375 HORN, Alexander [et al.]. Peeping at the Corpus - What is Really Going on Behind the Equality and Welfare Items of the Manifesto Project? Journal of European Social Policy. 27 (2017) No. 5: 403.

1376 HOSKING, David. Promoting Accessibility for Disabled People Using EU Standardisation Policy. European Law Review. 42 (2017) No. 2: 145.

1377 IOSIFIDI, Maria; Mylonidis, Nikolaos. Relative Effective Taxation and Income Inequality: Evidence from OECD Countries. Journal of European Social Policy. 27 (2017) No. 1: 57.

1378 JAKOBSEN, Vibeke; Pedersen, Peder J. Poverty Risk Among Older Immigrants in a Scandinavian Welfare State. European Journal of Social Security. 19 (2017) No. 3: 242 .

1379 JENSEN, Per H. Cause and Effects of Female Labour Force Participation in Local Welfare Systems. European Societies. 19 (2017) No. 2: 121.

1380 KASEARU, Kairi; Maestripieri, Lara; Ranci, Constanzo. Women at Risk: The Impact of Labour-Market Participation, Education and Household Structure on the Economic Vulnerability of Women through Europe. European Societies. 19 (2017) No. 2: 202.

1381 KAZEPOV, Yuri; Ranci, Constanzo. Is Every Country Fit for Social Investment? Italy as an Adverse Case. Journal of European Social Policy. 27 (2017) No. 1: 90.

1382 KOLLMAN, Kelly. Pioneering Marriage for Same-Sex Couples in the Netherlands. Journal of European Public Policy. 24 (2017) No. 1: 100.

1383 KOREH, Michal. The Fiscal Politics of Welfare State Expansion: The Case of Social Insurance in Israel. Journal of European Social Policy. 27 (2017) No. 2: 158.

1384 KÖTHEMANN, Dennis. Societal Development, Social Stratification and Powerand Achievement-Values Inglehart's Scarcity Hypothesis and the Theory of the Social Production Functions in the Comparative Study of Values. European Societies. 19 (2017) No. 4: 346.

1385 KOWALEWSKA, Helen. Beyond the 'Train-First'/'Work-First' Dichotomy: How Welfare States Help or Hinder Maternal Employment. Journal of European Social Policy. 27 (2017) No. 1: 3.

1386 KUITTO, Kati. From Social Security to Social Investment? Compensating and Social Investment Welfare Policies in a Life-Course Perspective. Journal of European Social Policy. 26 (2016) No. 5: 442.

1387 KUIVALAINEN, Susan; Erola, Jani. Swinging Support? Economic Cycles and Changes in the Public Attitudes towards Welfare Recipients in Finland 19952010. European Societies. 19 (2017) No. 4: 419. 
1388 LEESON, Peter T.; Pierson, Joshua. Economic Origins of the No-Fault Divorce Revolution. European Journal of Law and Economics. 43 (2017) No. 3: 419.

1389 LIECHTI, Lena. Resource-Related Inequalities in Mothers' Employment in Two Family-Policy Regimes: Evidence from Switzerland and West Germany. European Societies. 19 (2017) No. 1: 91.

1390 LOFTIS, Matt W.; Mortensen, Peter B. A New Approach to the Study of Partisan Effects on Social Policy. Journal of European Public Policy. 24 (2017) No. 6: 890.

1391 LOMAZZI, Vera. Gender Role Attitudes in Italy: 1988-2008. A Path-Dependency Story of Traditionalism. European Societies. 19 (2017) No. 4: 370.

1392 LYKKE HINDHEDE, Anette. Neighbourhood Renewal, Participation, and Social Capital in Deprived Areas: Unintended Consequences in a Nordic Context. European Societies. 18 (2016) No. 5: 535.

1393 MARCKMANN, Bella. All is not Relative: Intergenerational Norms in Europe. European Societies. 19 (2017) No. 4: 466.

1394 MCKEEVER, Gráinne; Simpson, Mark. Worlds of Welfare Collide Implementing a European Unemployment Benefit Scheme in the UK. European Journal of Social Security. 19 (2017) No. 1: 21.

1395 MERTENS, Daniel. Borrowing for Social Security? Credit, Asset-Based Welfare and the Decline of the German Savings Regime. Journal of European Social Policy. 27 (2017) No. 5: 474.

1396 NEERGAARD, Ulla. Europe and the Welfare State-Friends, Foes, or . . .? Yearbook of European Law. 35 (2016) No. 1: 341.

1397 NYS, Inne; Stevens, Yves; Forman, Jonathan. Early Access to Occupational Pension Plans Belgium vs USA. Borrowing, Pledging, Hardship Withdrawal or Early Distribution. European Journal of Social Security. 19 (2017) No. 2: 186.

1398 PEETERS, Bruno; Verschueren, Herwig. The Impact of European Union Law on the Interaction of Members States' Sovereign Powers in the Policy Fields of Social Protection and Personal Income Tax Benefits. EC Tax Review. 25 (2016) No. 5/6: 262.

1399 PLANTENGA, Janneke; Remery, Chantal. Out-of-School Childcare: Exploring Availability and Quality in EU Member States. Journal of European Social Policy. 27 (2017) No. 1: 25.

1400 PRABHAKAR, Rajiv. Why Do People Opt-Out or Not Opt-Out of Automatic Enrolment? A Focus Group Study of Automatic Enrolment into a Workplace Pension in the United Kingdom. Journal of European Social Policy. 27 (2017) No. 5: 447.

1401 PROSSER, Thomas. Economic Union without Social Union: The Strange Case of the European Social Dialogue. Journal of European Social Policy. 26 (2016) No. 5: 460.

1402 PROTSCH, Paula; Solga, Heike. Going across Europe for an Apprenticeship? A Factorial Survey Experiment on Employers' Hiring Preferences in Germany. Journal of European Social Policy. 27 (2017) No. 4: 387.

1403 RAPP, Carolin. Shaping Tolerant Attitudes towards Immigrants: The Role of Welfare State Expenditures. Journal of European Social Policy. 27 (2017) No. 1: 40.

1404 RÖMER, Friederike. Generous to All or 'Insiders Only'? The Relationship between Welfare State Generosity and Immigrant Welfare Rights. Journal of European Social Policy. 27 (2017) No. 2: 173.

1405 SCHADLER, Cornelia [et al.]. Key Practices of Equality Within Long Parental Leaves. Journal of European Social Policy. 27 (2017) No. 3: 247. 
1406 SCHLEUTKER, Elina. Women's Work-Life Preferences: Reconceptualization and Cross-Country Description Over Time. European Societies. 19 (2017) No. 3: 292.

1407 SCHMIDT-CATRAN, Alexander W.; Careja, Romana. Institutions, Culture and Migrants' Preference for State-Provided Welfare. Longitudinal Evidence from Germany. Journal of European Social Policy. 27 (2017) No. 2: 197.

1408 SCHOBER, Pia; Schmitt, Christian. Day-Care Availability, Maternal Employment and Satisfaction of Parents: Evidence from Cultural and Policy Variations in Germany. Journal of European Social Policy. 27 (2017) No. 5: 433.

1409 SINDBJERG MARTINSEN, Dorte; Mayoral Díaz-Asensio, Juan A. A Judicialisation of Healthcare Policies in Denmark and Spain? The Universalist Healthcare Model Meets the European Union. Comparative European Politics. 15 (2017) No. 3: 414.

1410 SKEVIK GRØDEM, Anne. Family-Oriented Policies in Scandinavia and the Challenge of Immigration. Journal of European Social Policy. 27 (2017) No. 1: 77.

1411 SOKOL, Tomislav. Comprehensive Sickness Insurance as a Condition for EU Citizens' Residence in other Member States: A Need for Reform? European Journal of Social Security. 18 (2016) No. 4: 380.

1412 STEVEnS, Yves. The Silent Pension Pillar Implosion. European Journal of Social Security. 19 (2017) No. 2: 98.

1413 STILLER, Sabina. The Interplay of Actor-Related Strategies and Political Context: A Fuzzy-Set QCA Analysis of Structural Reforms in Continental Welfare States. Journal of European Public Policy. 24 (2017) No. 1: 81.

1414 STRBAN, Grega. Family Benefits in the EU: Is it Still Possible to Coordinate Them? Maastricht Journal of European and Comparative Law. 23 (2016) No. 5: 775.

1415 TOSI, Marco. Leaving-Home Transition and Later Parent-Child Relationships: Proximity and Contact in Italy. European Societies. 19 (2017) No. 1: 69.

1416 VAN MEERTEN, Hans; Schmidt, Elmar. Compulsory Membership of Pension Schemes and the Free Movement of Services in the EU. European Journal of Social Security. 19 (2017) No. 2: 118.

1417 VARVAS̆TIAN, Samvel. Promoting Human Health and the Functioning of the Internal Market: The Reaffirmation of the Tobacco Products Directive's Key Objectives in Poland v. Parliament and Council, Pillbox 38 and Philip Morris Brands and Others. European Public Law. 23 (2017) No. 2: 271.

1418 VERSCHUEREN, Herwig. Scenarios for Brexit and Social Security. Maastricht Journal of European and Comparative Law. 24 (2017) No. 3: 367.

1419 VERSCHUEREN, Nicolas. From Steel House to Mass Housing for the Working Class. Journal of European Integration History. 22 (2016) No. 2: 249.

1420 VILlAR, Feliciano; Serrat, Rodrigo; Celdrán, Montserrat. Participation of Spanish Older People in Educational Courses: The Role of Sociodemographic and Active Ageing Factors. Journal of European Social Policy. 26 (2016) No. 5: 417.

1421 VOLLAARD, Hans. Patient Mobility, Changing Territoriality and Scale in the EU's Internal Market. Comparative European Politics. 15 (2017) No. 3: 435.

1422 VOLLAARD, Hans; Sindbjerg Martinsen, Dorte. The Rise of a European Healthcare Union. Comparative European Politics. 15 (2017) No. 3: 337.

1423 WANG, Jinxian; van Vliet, Olaf. Social Assistance and Minimum Income Benefits: Benefit Levels, Replacement Rates and Policies across 26 Oecd Countries, 1990-2009. European Journal of Social Security. 18 (2016) No. 4: 333.

1424 WANG, Yi-Ting; Lindenfors, Patrik; Sundström, Aksel; Jansson, Fredrik; Paxton, Pamela; Lindberg, Staffan I. Women's Rights in Democratic Transitions: A Global Sequence Analysis, 1900-2012. European Journal of Political Research. 56 (2017) No. 4: 735. 
1425 WINDWEHR, Jana. Europeanization in Pension Policy: The Crisis as a GameChanger? Journal of Contemporary European Research. 13 (2017) No. 3: 18 pp.

1426 WOTSCHACH, Philip. Leave Saving Options Over the Life Course - Only for the Highly Skilled? Evidence from Two German Best-Practice Companies. European Societies. 19 (2017) No. 4: 396.

1427 ZAIDI, Asghar [et al.]. Measuring Active and Healthy Ageing in Europe. Journal of European Social Policy. 27 (2017) No. 2: 138.

10 Economic and Social Cohesion - Structural policies - Regional policies

(Structural funds / European Regional Defelopment Fund / European Social Fund / Community initiatives / Innovative actions / Cohesion Fund / Spatial planning)

1428 ADDIE, Jean-Paul D. From the Urban University to Universities in Urban Society. Regional Studies. 51 (2017) No. 7: 1089.

1429 ALLAN, Grant; McGregor, Peter; Swales, Kim. Greening Regional Development: Employment in Low-Carbon and Renewable Energy Activities. Regional Studies. 51 (2017) No. 8: 1270.

1430 ANDERSEN, Bengt; Gunnar Røe, Per. The Social Context and Politics of Large Scale Urban Architecture: Investigating the Design of Barcode, Oslo. European Urban and Regional Studies. 24 (2017) No. 3: 304.

1431 ANGELAKIS, Antonios; Galanakis, Kostas. A Science-Based Sector in the Making: The Formation of the Biotechnology Sector in Two Regions. Regional Studies. 51 (2017) No. 10: 1542.

1432 ANTONELLI, Cristiano; Colombelli, Alessandra. The Locus of Knowledge Externalities and the Cost of Knowledge. Regional Studies. 51 (2017) No. 8: 1151.

1433 ANTONELLI, Cristiano [et al.]. Knowledge Composition, Jacobs Externalities and Innovation Performance in European Regions. Regional Studies. 51 (2017) No. 11: 1708.

1434 BALDI, Simona; Vannoni, Davide. The Impact of Centralization on Pharmaceutical Procurement Prices: The Role of Institutional Quality and Corruption. Regional Studies. 51 (2017) No. 3: 426.

1435 BALlAS, Dimitris; Dorling, Danny; Hennig, Benjamin. Analysing the Regional Geography of Poverty, Austerity and Inequality in Europe: A Human Cartographic Perspective. Regional Studies. 51 (2017) No. 1: 174.

1436 BARNFIELD, Andrew. Experiencing Post-Socialism: Running and Urban Space in Sofia, Bulgaria. European Urban and Regional Studies. 24 (2017) No. 4: 368.

1437 BARUFFALDI, Stefano; Raffo, Julio. The Geography of Duplicated Inventions: Evidence from Patent Citations. Regional Studies. 51 (2017) No. 8: 1232.

1438 BASILE, Roberto; Pittiglio, Rosanna; Reganati, Filippo. Do Agglomeration Externalities Affect Firm Survival? Regional Studies. 51 (2017) No. 4: 548.

1439 BASKARAN, Thushyanthan; Feld, Lars P.; Necer, Sarah. Depressing Dependence? Transfers and Economic Growth in the German States, 1975-2005. Regional Studies. 51 (2017) No. 12: 1815.

1440 BENNEWORTH, Paul; Pinheiro, Rómulo; Karlsen, James. Strategic Agency and Institutional Change: Investigating the Role of Universities in Regional Innovation Systems (RISs). Regional Studies. 51 (2017) No. 2: 235.

1441 BENTLEY, Gill; Pugalis, Lee; Shutt, John. Leadership and Systems of Governance: The Constraints on the Scope for Leadership of Place-Based Development in Sub-National Territories. Regional Studies. 51 (2017) No. 2: 194. 
1442 BERGÉ, Laurent R.; Wanzenböck, Iris; Scherngell, Thomas. Centrality of Regions in R\&D Networks: A New Measurement Approach Using the Concept of Bridging Paths. Regional Studies. 51 (2017) No. 8: 1165.

1443 BERGER, Thor; Frey, Carl Benedikt. Industrial Renewal in the 21st Century: Evidence from US Cities. Regional Studies. 51 (2017) No. 3: 404.

1444 BERTAMINO, Federica [et al.]. Regional Policies for Innovation: The Case of Technology Districts in Italy. Regional Studies. 51 (2017) No. 12: 1826.

1445 BORDIGNON, Massimo; Grembi, Veronica; Piazza, Santino. Who Do You Blame in Local Finance? An Analysis of Municipal Financing in Italy. European Journal of Political Economy. (2017) No. 49: 146.

1446 BOSCHMA, Ron. Relatedness as Driver of Regional Diversification: A Research Agenda. Regional Studies. 51 (2017) No. 3: 351.

1447 BOSCHMA, Ron [et al.]. Towards a Theory of Regional Diversification: Combining Insights from Evolutionary Economic Geography and Transition Studies. Regional Studies. 51 (2017) No. 1: 31.

1448 BOTTAZZI, Giulio; Gragnolati, Urgo M.; Vanni, Fabio. Non-Linear Externalities in Firm Localization. Regional Studies. 51 (2017) No. 8: 1138.

1449 BOUZAROVSKI, Stefan; Tirado Herrero, Sergio. The Energy Divide: Integrating Energy Transitions, Regional Inequalities and Poverty Trends in the European Union. European Urban and Regional Studies. 24 (2017) No. 1: 69.

1450 BRUSAPORCI, Gianfranco. The Impact of EU Multi-Level Regionalism Strategy on Bulgarian Local Authorities: Qualitative Comparative Analysis among Nine Border Areas. Southeast European and Black Sea Studies. 17 (2017) No. 3: 347.

1451 BRYAN, Jane; Evans, Neil; Jones, Calvin; Munday, Max. Regional Electricity Generation and Employment in UK Regions. Regional Studies. 51 (2017) No. 3: 414.

1452 BUBBICO, Antonio; Elkink, Johan A.; Okolikj, Martin. Quality of Government and Regional Competition: A Spatial Analysis of Subnational Regions in the European Union. European Journal of Political Research. 56 (2017) No. 4: 887.

1453 CABANELAS, Pablo [et al.]. The Governance of Regional Research Networks: Lessons from Spain. Regional Studies. 51 (2017) No. 7: 1008.

1454 CALZADA, Igor. Metropolitan and Post-National Urbanity beyond (Pluri) national(al) - States in the EU: Benchmarking Scotland, Catalonia and the Basque Country. Journal of Ethnopolitics and Minority Issues in Europe. 16 (2017) No. 1: 51.

1455 CATTANEO, Mattia [et al.]. University Spatial Competition for Students: The Italian Case. Regional Studies. 51 (2017) No. 5: 750.

1456 CHAKRABARTI, Rajashri; Roy, Joydeep. Effect of Constraints on Tiebout Competition: Evidence from a School Finance Reform. Regional Studies. 51 (2017) No. 5: 765.

1457 COFFANO, Monica; Foray, Dominique; Pezzoni, Michele. Does Inventor Centrality Foster Regional Innovation? The Case of the Swiss Medical Devices Sector. Regional Studies. 51 (2017) No. 8: 1206.

1458 CRANKSHAW, Owen. Social Polarization in Global Cities: Measuring Changes in Earnings and Occupational Inequality. Regional Studies. 51 (2017) No. 11: 1612.

1459 CRESCENZI, Riccardo; Iammarino, Simona. Global Investments and Regional Development Trajectories: The Missing Links. Regional Studies. 51 (2017) No. 1: 97.

1460 CZALLER, Lázsló. Increasing Social Returns to Human Capital: Evidence from Hungarian Regions. Regional Studies. 51 (2017) No. 3: 467. 
1461 DAHLMANN, Frederik; Kolk, Ans; Lindeque, Johan. Emerging Energy Geographies: Scaling and Spatial Divergence in EUropean Electricity Generation Capacity. European Urban and Regional Studies. 24 (2017) No. 4: 381.

1462 DALL'ERBA, Sandy; Fang, Fang. Meta-Analysis of the Impact of European Union Structural Funds on Regional Growth. Regional Studies. 51 (2017) No. 6: 822.

1463 DAUNFELDT, Sven-Olov [et al.]. What Happens When IKEA Comes to Town? Regional Studies. 51 (2017) No. 2: 313.

1464 DE SIANO, Rita; D’Uva, Marcella. Fiscal Decentralization and Spillover Effects of Local Government Public Spending: The Case of Italy. Regional Studies. 51 (2017) No. 10: 1507.

1465 DE SILVA, Dakshina G.; Hubbard, Timothy P.; McComb, Robert P.; Schiller, Anita R. Entry, Growth and Survival in the Green Industry. Regional Studies. 51 (2017) No. 12: 1774.

1466 DELLMUTH, Lisa Maria; Schraff, Dominik; Stoffel, Michael F. Distributive Politics, Electoral Institutions and European Structural and Investment Funding: Evidence from Italy and France. Journal of Common Market Studies. 55 (2017) No. 2: 275 .

1467 DEMPSEY, Kara E.; Wilbrand, Stephanie M. The Role of the Region in the European Landscape Convention. Regional Studies. 51 (2017) No. 6: 909.

1468 DI CATALDO, Marco; Rodríguez-Pose, Andrés. What Drives Employment Growth and Social Inclusion in the Regions of the European Union? Regional Studies. 51 (2017) No. 12: 1840.

1469 DI FELICIANTONIO, Cesare. The Reactions of Neighbourhoods to the Eviction of Squatters in Rome: An Account of the Making of Precarious Investor Subjects. European Urban and Regional Studies. 24 (2017) No. 4: 352.

1470 DIVELLA, Marialuisa. Cooperation Linkages and Technological Capabilities Development Across Firms. Regional Studies. 51 (2017) No. 10: 1494.

1471 DÖPKE, Jörg [et al.]. Multidimensional Well-being and Regional Disparities in Europe. Journal of Common Market Studies. 55 (2017) No. 5: 1026.

1472 DREJER, Ina; Richter Østergaard, Christian. Exploring Determinants of Firms' Collaboration with Specific Universities: Employee-Driven Relations and Geographical Proximity. Regional Studies. 51 (2017) No. 8: 1192.

1473 DUBOIS, Eric; Leprince, Matthieu. Do Closeness and Stake Increase Voter Turnout? Evidence from Election Results in Small French Towns in Brittany. Regional Studies. 51 (2017) No. 4: 575.

1474 DUNFORD, Michael; Liu, Weidong. Uneven and Combined Development. Regional Studies. 51 (2017) No. 1: 69.

1475 EPIFANI, Ilenia; Nicolini, Rosella. Modelling Population Density Over Time: How Spatial Distance Matters. Regional Studies. 51 (2017) No. 4: 602.

1476 ERIKSSON, Rikard H.; Hane-Weijman, Emelie. How do Regional Economies Respond to Crises? The Geography of Job Creation and Destruction in Sweden (1990-2010). European Urban and Regional Studies. 24 (2017) No. 1: 87.

1477 ERMINI, Barbara; Santolini, Raffaella. Urban Sprawl and Property Tax of a City's Core and Suburbs: Evidence from Italy. Regional Studies. 51 (2017) No. 9: 1374.

1478 ESCRIBÁ-PÉREZ, Javier; Murgui-García, María José. Do Market Regulations Reduce Investment? Evidence from European Regions. Regional Studies. 51 (2017) No. 9: 1336.

1479 FAGGIAN, Alessandra; Rajbhandari, Isha; Dotzel, Kathryn R. The Interregional Migration of Human Capital and its Regional Consequences: A Review. Regional Studies. 51 (2017) No. 1: 128. 
1480 FERREIRA, Jennifier. Considering National Varieties in the Temporary Staffing Industry and Institutional Change: Evidence from the UK and Germany. European Urban and Regional Studies. 24 (2017) No. 3: 241.

1481 FIRMINO COSTA DE SILVA, Diego; Elhorst, J. Paul; da Mota Silveira Neto, Raul. Urban and Rural Population Growth in a Spatial Panel of Municipalities. Regional Studies. 51 (2017) No. 6: 894.

1482 FLORIDA, Richard; Adler, Patrick; Mellander, Charlotta. The City as Innovation Machine. Regional Studies. 51 (2017) No. 1: 86.

1483 FRATESI, Ugo; Wishlade, Fiona G. The Impact of European Cohesion Policy in Different Contexts. Regional Studies. 51 (2017) No. 6: 817.

1484 FREEMAN, Julie; Hancock, Linda. Energy and Communication Infrastructure for Disaster Resilience in Rural and Regional Australia. Regional Studies. 51 (2017) No. 6: 933.

1485 FRENKEL, Ammon; Leck, Eran. Spatial Aspects of Education-Job Matching in Israel. Regional Studies. 51 (2017) No. 7: 1063.

1486 GAGLIARDI, Luisa; Percoco, Marco. The Impact of European Cohesion Policy in Urban and Rural Regions. Regional Studies. 51 (2017) No. 6: 857.

1487 GARCÍA MEJUTO, Diego. A Europe of Multiple Flows: Contested Discursive Integration in Trans-European Transport Infrastructure Policy-Making. European Urban and Regional Studies. 24 (2017) No. 4: 425.

1488 GARMANN, Sebastian. Electoral Cycles in Public Administration Decisions: Evidence from German Municipalities. Regional Studies. 51 (2017) No. 5: 712.

1489 GARRETSEN, Harry; Marlet, Gerard. Amenities and the Attraction of Dutch Cities. Regional Studies. 51 (2017) No. 5: 724.

1490 GIBBS, David; O’Neill, Kirstie. Future Green Economies and Regional Development: A Research Agenda. Regional Studies. 51 (2017) No. 1: 161.

1491 GIORDANO, Benito. Exploring the Role of the ERDF in Regions with Specific Geographical Features: Islands, Mountainous and Sparsely Populated Areas. Regional Studies. 51 (2017) No. 6: 869.

1492 GLAESER, Edward L.; Millett Steinberg, Bryce. Transforming Cities: Does Urbanization Promote Democratic Change? Regional Studies. 51 (2017) No. 1: 58.

1493 GREEN, Anne; Livanos, Ilias. Involuntary Non-standard Employment in Europe. European Urban and Regional Studies. 24 (2017) No. 2: 175.

1494 GRILLITSCH, Markus; Nilsson, Magnus. Firm Performance in the Periphery: On the Relation between Firm-Internal Knowledge and Local Knowledge Spillovers. Regional Studies. 51 (2017) No. 8: 1219.

1495 GROSSMANN, Katrin; Kabisch, Nadja; Kabisch, Sigrun. Understanding the Social Development of a Post-Socialist Large Housing Estate: The Case of LeipzigGrünau in Eastern Germany in Long-Term Perspective. European Urban and Regional Studies. 24 (2017) No. 2: 142.

1496 HAN, Sehee. Social Capital and Interlocal Service Collaboration in US Counties. Regional Studies. 51 (2017) No. 5: 674.

1497 HARRIS, Richard; Moffat, John. The Sources of the Scotland-Rest of the UK Productivity Gap: Implications for Policy. Regional Studies. 51 (2017) No. 9: 1297.

1498 HARRISON, John; Smith, Darren P.; Kinton, Chloe. Relational Regions 'in the Making': Institutionalizing New Regional Geographies of Higher Education. Regional Studies. 51 (2017) No. 7: 1020.

1499 HARRISON, John; Turok, Ivan. Universities, Knowledge and Regional Development. Regional Studies. 51 (2017) No. 7: 977. 
1500 HENING NORMANN, Roger; Garmann Johnsen, Hans Chr. Emergence of Regional Leadership - a Field Approach. Regional Studies. 51 (2017) No. 2: 273.

1501 HENLEY, Andrew. The Post-Crisis Growth in the Self-Employed: Volunteers or Reluctant Recruits? Regional Studies. 51 (2017) No. 9: 1312.

1502 HENRY, Nick. Continuing the International Contribution to Critical Urban and Regional Studies. European Urban and Regional Studies. 24 (2017) No. 1: 3.

1503 HERMANNSSON, Kristinn [et al.]. The External Benefits of Higher Education. Regional Studies. 51 (2017) No. 7: 1077.

1504 HERRERO-ALCALDE, Ana; Tránchez-Martín, José Manuel. Demographic, Political, Institutional and Financial Determinants of Regional Social Expenditure: The Case of Spain. Regional Studies. 51 (2017) No. 6: 920.

1505 HIEPEL, Claudia. 'Borders are the Scars of History'? Cross-border Co-operation in Europe - the Example of the EUREGIO. Journal of European Integration History. 22 (2016) No. 2: 263.

1506 HOPKINS, Benjamin. Analysing the 'Migrant Work Ethic' - Comparing Managers' Perceptions of Local Workers and Central and Eastern European Migrants in the United Kingdom. European Urban and Regional Studies. 24 (2017) No. 4: 442.

1507 HUDSON, Ray. Facing Forwards, Looking Backwards: Coming to Terms with Continuing Uneven Development in Europe. European Urban and Regional Studies. 24 (2017) No. 2: 138.

1508 JAHN, Malte. Extending the FLQ Formula: A Location Quotient-Based Interregional Input-Output Framework. Regional Studies. 51 (2017) No. 10: 1518.

1509 KEATING, Michael. Contesting European Regions. Regional Studies. 51 (2017) No. 1: 9.

1510 KESSING, Sebastian G.; Strozzi, Chiara. The Regional Distribution of Public Employment: Theory and Evidence. Regional Studies. 51 (2017) No. 7: 1100.

1511 KNIGHT, Eric; Wójcik, Dariusz. Geographical Linkages in the Financial Services Industry: A Dialogue with Organizational Studies. Regional Studies. 51 (2017) No. 1: 116 .

1512 KNIPPSCHILD, Robert; Vock, Alexander. The Conformance and Performance Principles in Territorial Cooperation: A Critical Reflection on the Evaluation of INTERREG Projects. Regional Studies. 51 (2017) No. 11: 1735.

1513 KOGLER, Dieter Franz. Relatedness as Driver of Regional Diversification: A Research Agenda - a Commentary. Regional Studies. 51 (2017) No. 3: 365.

1514 KOROSTELEVA, Julia; Belitski, Maksim. Entrepreneurial Dynamics and Higher Education Institutions in the Post-Communist World. Regional Studies. 51 (2017) No. 3: 439.

1515 KÜHN, Manfred; Bernt, Matthias; Colini, Laura. Power, Politics and Peripheralization: Two Eastern German Cities. European Urban and Regional Studies. 24 (2017) No. 3: 258.

1516 KYRIACOU, Andreas P.; Muinelo-Gallo, Leonel; Roca-Sagalés, Oriol. Regional Inequalities, Fiscal Decentralization and Government Quality. Regional Studies. 51 (2017) No. 6: 945.

1517 LARTY, Joanne; Jack, Sarah; Lockett, Nigel. Building Regions: A Resource-Based View of a Policy-Led Knowledge Exchange Network. Regional Studies. 51 (2017) No. 7: 994.

1518 LASARTE NAVAMUEL, Elena [et al.]. Higher Cost of Living in Urban Areas? An AIDS-Based Analysis of Food in Spain. Regional Studies. 51 (2017) No. 11: 1665. 
1519 LEE, Roger. Honouring Ray Hudson: Reflecting on Four Decades of Contribution to Economic Geography. European Urban and Regional Studies. 24 (2017) No. 2: 129.

1520 LI, Yingcheng; Phelps, Nicholas A. Knowledge Polycentricity and the Evolving Yangtze River Delta Megalopolis. Regional Studies. 51 (2017) No. 7: 1035.

1521 LIANF, Jiaochen. Trade Shocks, New Industry Entry and Industry Relatedness. Regional Studies. 51 (2017) No. 12: 1749.

1522 LILIUS, Johanna. Urban Space in the Everyday Lives of Mothers and Fathers on Family Leave in Helsinki. European Urban and Regional Studies. 24 (2017) No. 1: 104.

1523 LIN, George C.S. Water, Technology, Society and the Environment: Interpreting the Technopolitics of China's South-North Water Transfer Project. Regional Studies. 51 (2017) No. 3: 383.

1524 LISCIANDRA, Maurizio; Millemaci, Emanuele. The Economic Effect of Corruption in Italy: A Regional Panel Analysis. Regional Studies. 51 (2017) No. 9: 1387.

1525 LITZEL, Nicole. Does Embeddedness in Clusters Enhance Firm Survival and Growth? An Establishment-Level Analysis Using CORIS Data. Regional Studies. 51 (2017) No. 4: 563.

1526 LOS, Bart; McCann, Philip; Springford, John; Thissen, Mark. The Mismatch between Local Voting and the Local Economic Consequences of Brexit. Regional Studies. 51 (2017) No. 5: 786.

1527 LUNDBERG, Johan. Does Academic Research Affect Local Growth? Empirical Evidence Based on Swedish Data. Regional Studies. 51 (2017) No. 4: 586.

1528 MAHIEUX, Aurélie; Mejia-Dorantes, Lucia. Regeneration Strategies and Transport Improvement in a Deprived Area: What Can Be Learnt from Northern France? Regional Studies. 51 (2017) No. 5: 800.

1529 MAREK, Philipp; Titze, Mirko; Fuhrmesiter, Clemens; Blum, Ulrich. R\&D Collaborations and the Role of Proximity. Regional Studies. 51 (2017) No. 12: 1761.

1530 MASCIA, Daniele; Pallotti, Francesca; Angeli, Federica. Don't Stand so Close to me: Competitive Pressures, Proximity and Inter-Organizational Collaboration. Regional Studies. 51 (2017) No. 9: 1348.

1531 MATTHEIS, Frank. Repositioning Europe in the Study of Regions: Comparative Regionalism, Interregionalism and Decentred Regionalism. Journal of European Integration. 39 (2017) No. 4: 477.

1532 MCCRACKEN, Scott, Ramlogan-Dobson, Carlyn; Stack, Marie M. A Gravity Model of Remittance Determinants: Evidence from Latin America and the Caribbean. Regional Studies. 51 (2017) No. 5: 737.

1533 MCNABB, Robert; Munday, Max. The Stability of the Foreign Manufacturing Sector: Evidence and Analysis for Wales 1966-2003. European Urban and Regional Studies. 24 (2017) No. 1: 50.

1534 MEDEIROS, Eduardo. European Union Cohesion Policy and Spain: A Territorial Impact Assessment. Regional Studies. 51 (2017) No. 8: 1259.

1535 MELO, Patricia C. People, Places and Earnings Differentials in Scotland. Regional Studies. 51 (2017) No. 3: 389.

1536 MENDEZ, Carlos; Bachtler, John. Financial Compliance in the European Union: A Cross-National Assessment of Financial Correction Patterns and Causes in Cohesion Policy. Journal of Common Market Studies. 55 (2017) No. 3: 569.

1537 MENZEL, Max-Peter; Feldman, Maryann P.; Broekel, Tom. Institutional Change and Network Evolution: Explorative and Exploitative Tie Formations of Co-Inventors 
During the Dot-Com Bubble in the Research Triangle Region. Regional Studies. 51 (2017) No. 8: 1179.

1538 MONASTIRIOTIS, Vassilis; Kallioras, Dimitris; Petrakos, George. The Regional Impact of European Union Association Agreements: An Event-Analysis Approach to the Case of Central and Eastern Europe. Regional Studies. 51 (2017) No. 10: 1454.

1539 MORKUTE், Gintarè; Koster, Sierdjan; Van Dijk, Jouke. Employment Growth and Inter-Industry Job Reallocation: Spatial Patterns and Relatedness. Regional Studies. 51 (2017) No. 6: 958.

1540 MOSER, Mathias; Schnetzer, Matthias. The Income-Inequality Nexus in a Developed Country: Small-Scale Regional Evidence from Austria. Regional Studies. 51 (2017) No. 3: 454.

1541 MUNKEJORD, Mai Camilla. Local and Transnational Networking among Female Immigrant Entrepreneurs in Peripheral Rural Contexts: Perspectives on Russians in Finnmark, Norway. European Urban and Regional Studies. 24 (2017) No. 1: 7 .

1542 NICHOLDS, Alyson [et al.]. Making Sense of Variety in Place Leadership: The Case of England's Smart Cities. Regional Studies. 51 (2017) No. 2: 249.

1543 NIFO, Annamaria; Scalera, Domenico; Vecchione, Gaetano. The Rule of Law and Educational Choices: Evidence from Italian Regions. Regional Studies. 51 (2017) No. 7: 1048.

1544 NUCCIO, Massimiliano; Ponzini, Davide. What does a Cultural District Actually do? Critically Reappraising 15 years of Cultural District Policy in Italy. European Urban and Regional Studies. 24 (2017) No. 4: 405.

1545 NJØS, Rune [et al.]. Encounters between Cluster Theory, Policy and Practice in Norway: Hubbing, Blending and Conceptual Stretching. European Urban and Regional Studies. 24 (2017) No. 3: 274.

1546 OKABE, Tomohito; Kam, Timothy. Regional Economic Growth Disparities: A Political Economy Perspective. European Journal of Political Economy. (2017) No. 46: 26.

1547 PAASI, Anssi; Metzger, Jonathan. Foregrounding the Region. Regional Studies. 51 (2017) No. 1: 19.

1548 PASTOR, José Manuel [et al.]. Rich Regions, Poor Regions and Bank Branch Deregulation in Spain. Regional Studies. 51 (2017) No. 11: 1678.

1549 PELlEGRINI, Guido; Muccigrosso, Teo. Do Subsidized New Firms Survive Longer? Evidence from a Counterfactual Approach. Regional Studies. 51 (2017) No. 10: 1483.

1550 PELUCHA, Martin; Kveton, Viktor. The Role of EU Rural Development Policy in the Neo-Productivist Agricultural Paradigm. Regional Studies. 51 (2017) No. 12: 1860.

1551 PERCOCO, Marco. Impact of European Cohesion Policy on Regional Growth: Does Local Economic Structure Matter? Regional Studies. 51 (2017) No. 6: 833.

1552 PERRONS, Diane. Social Theory, Economic Geography, Space and Place: Reflections on the Work of Ray Hudson. European Urban and Regional Studies. 24 (2017) No. 2: 133.

1553 PIKE, Andy; Rodríguez-Pose; Andrés; Tomaney, John. Shifting Horizons in Local and Regional Development. Regional Studies. 51 (2017) No. 1: 46.

1554 PUGH, Rhiannon. Universities and Economic Development in Lagging Regions: 'Triple Helix' Policy in Wales. Regional Studies. 51 (2017) No. 7: 982. 
1555 QUATRARO, Francesco; Usai, Stefano. Are Knowledge Flows all Alike? Evidence from European Regions. Regional Studies. 51 (2017) No. 8: 1246.

1556 QUATRARO, Francesco; Usai, Stefano. Knowledge Flows, Externalities and Innovation Networks. Regional Studies. 51 (2017) No. 8: 1133.

1557 RAAGMAA, Garri; Keerberg, Anne. Regional Higher Education Institutions in Regional Leadership and Development. Regional Studies. 51 (2017) No. 2: 260.

1558 RIOS, Vicente. What Drives Unemployment Disparities in European Regions? A Dynamic Spatial Panel Approach. Regional Studies. 51 (2017) No. 11: 1599.

1559 RUSPASINGHA, Anil. Local Business Ownership and Local Economic Performance: Evidence from US Counties. Regional Studies. 51 (2017) No. 5: 659.

1560 SACCHI, Agnese; Salotti, Simone. The Influence of Decentralized Taxes and Intergovernmental Grants on Local Spending Volatility. Regional Studies. 51 (2017) No. 4: 507.

1561 SARMETNO, João; Ferreira, Marisa. Reconfiguring the Public and the Private: Noc-Noc Arts Festival, Guimarães, Portugal. European Urban and Regional Studies. 24 (2017) No. 2: 193.

1562 SCHÄFFLER, Johannes; Hecht, Veronika; Moritz, Michael. Regional Determinants of German FDI in the Czech Republic: New Evidence on the Role of Border Regions. Regional Studies. 51 (2017) No. 9: 1399.

1563 SCHLAPPA, Hans. Co-producing the Cities of Tomorrow: Fostering Collaborative Action to Tackle Decline in Europe's Shrinking Cities. European Urban and Regional Studies. 24 (2017) No. 2: 162.

1564 SCHWAN, Michael. Which Roads Lead to Wall Street? The Financialization of Regions in the European Union. Comparative European Politics. 15 (2017) No. 4: 661.

1565 SMITH, Natalya; Thomas, Ekaterina. Regional Conditions and Innovation in Russia: The Impact of Foreign Direct Investment and Absorptive Capacity. Regional Studies. 51 (2017) No. 9: 1412.

1566 SOTARAUTA, Markku; Beer, Andrew. Governance, Agency and Place Leadership: Lessons from a Cross-National Analysis. Regional Studies. 51 (2017) No. 2: 210.

1567 SOTARAUTA, Markku; Beer, Andrew; Gibney, John. Making Sense of Leadership in Urban and Regional Development. Regional Studies. 51 (2017) No. 2: 187.

1568 SOULIOTIS, Nicos; Alexnadri, Georgia. From Embedded to Uncompromising Neoliberalism: Competitiveness Policies and European Union Interscalar Relations in the Case of Greece. European Urban and Regional Studies. 24 (2017) No. 3: 227.

1569 STEIN, Christian; Michel, Boris; Glasze, Georg; Pütz, Robert. Learning from Failed Policy Mobilities: Contradictions, Resistances and Unintended Outcomes in the Transfer of 'Business Improvement Districts' to Germany. European Urban and Regional Studies. 24 (2017) No. 1: 35.

1570 STERNBERG, Rolf. Creativity Support Policies as a Means of Development Policy for the Global South? A Critical Appraisal of the UNESCO Creative Economy Report 2013. Regional Studies. 51 (2017) No. 2: 336.

1571 SURUBARU, Neculai-Cristian. Administrative Capacity or Quality of Political Governance? EU Cohesion Policy in the New Europe, 2007-13. Regional Studies. 51 (2017) No. 6: 844.

1572 THIEL, Joachim. Creative Cities and the Reflexivity of the Urban Creative Economy. European Urban and Regional Studies. 24 (2017) No. 1: 21.

1573 TRIVELLATO, Benedetta. How Can 'Smart' Also be Socially Sustainable? Insights from the Case of Milan. European Urban and Regional Studies. 24 (2017) No. 4: 337. 
1574 TUROK, Ivan [et al.]. Global Reversal, Regional Revival? Regional Studies. 51 (2017) No. 1: 1 .

1575 VESTRUM, Ingebjørg; Rasmussen, Einar; Carter, Sara. How Nascent Community Enterprises Build Legitimacy in Internal and External Environments. Regional Studies. 51 (2017) No. 11: 1721.

1576 VIVES, Luna. The European Union-West African Sea Border: Anti-immigration Strategies and Territoriality. European Urban and Regional Studies. 24 (2017) No. 2: 209.

1577 WACHSMUTH, David. Competitive Multi-City Regionalism: Growth Politics Beyond the Growth Machine. Regional Studies. 51 (2017) No. 4: 643.

1578 WEBBER, Michael; Crow-Miller, Britt; Rogers, Sarah. The South-North Water Transfer Project: Remaking the Geography of China. Regional Studies. 51 (2017) No. 3: 370 .

1579 WIXE, Sofia; Andersson, Martin. Which Types of Relatedness Matter in Regional Growth? Industry, Occupation and Education. Regional Studies. 51 (2017) No. 4: 523.

1580 WOJAN, Timothy R. Metaphors of Regional Policy: Cities as Engines, Multilevel Governance in Gardens. Regional Studies. 51 (2017) No. 2: 324.

1581 XIN CUI, Cathy; Hanley, Nick; McGregor, Peter; Swales, Kim; Turner, Karen; Ping Yin, Ya. Impacts of Regional Productivity Growth, Decoupling and Pollution Leakage. Regional Studies. 51 (2017) No. 9: 1324.

1582 YEUNG, Godfrey; He, Canfei; Zhang, Peng. Rural Banking in China: Geographically Accessible but Still Financially Excluded? Regional Studies. 51 (2017) No. 2: 297.

1583 YILMAZKUDAY, Hakan. Individual Tax Rates and Regional Tax Revenues: A Cross-State Analysis. Regional Studies. 51 (2017) No. 5: 701.

1584 ZHU, Minyan; Peyrache, Antonio. The Quality and Efficiency of Public Service Delivery in the UK and China. Regional Studies. 51 (2017) No. 2: 285.

\section{Environment}

(Sustainable development / Industry and environment / Transport and environment / Atmospheric pollution / Aquatic environment / Economic instruments / Chemicals / Precautionary principle / Waste / Noise)

1585 ALAM, Shawkat; Nurhidayah, Laely. The International Law on Transboundary Haze Pollution: What Can We Learn from the Southeast Asia Region? Review of European Comparative and International Environmental Law. 26 (2017) No. 3: 243.

1586 ALARANTA, Joonas; Turunen, Topi. Drawing a Line between European Waste and Chemicals Regulation. Review of European Comparative and International Environmental Law. 26 (2017) No. 2: 163.

1587 BOGOJEVIC, Sanja; Petit, Nicolas. Deterring the State versus the Firm: Soft and Hard Deterrence Regimes in EU Law. Columbia Journal of European Law. 23 (2016) No. 1: 55 .

1588 BREMER, Nicolas. Post-environmental Impact Assessment Monitoring of Measures or Activities with Significant Transboundary Impact: An Assessment of Customary International Law. Review of European Comparative and International Environmental Law. 26 (2017) No. 1: 80.

1589 BROUSSARD, Giovanni. Building an Effective Criminal Justice Response to Wildlife Trafficking: Experiences from the ASEAN Region. Review of European Comparative and International Environmental Law. 26 (2017) No. 2: 118. 
1590 BYRNE, Adam. Trouble In the Air: Recent Developments Under the 1979 Convention on Long-Range Transboundary Air Pollution. Review of European, Comparative \& International Environmental Law. 26 (2017) No. 3: 210.

1591 CASSOTTA, Sandra. The Paris Agreement in Logic of Multi-regulatory Governance: A Step Forward to a New Concept of 'Global Progressive Adaptive-Mitigation'? European Energy and Enviromental Law Review. 25 (2016) No. 6: 196.

1592 ČAVOŠKI, Aleksandra. The Unintended Consequences of EU Law and Policy on Air Pollution. Review of European, Comparative \& International Environmental Law. 26 (2017) No. 3: 255.

1593 DE BAERE, Geert; Nowak, Janek Tomasz. The Right to 'Not Prohibitively Expensive' Judicial Proceedings under the Aarhus Convention and the ECJ as an International (Environmental) Law Court: Edwards and Pallikaropoulos. Common Market Law Review. 53 (2016) No. 6: 1727.

1594 DUBNER, Barry Hart; Vargas, Loany M. On the Law of Pirate Fishing and Its Connection to Human Rights Violations and to Environmental Degradation - A Multi-National Disaster. Journal of Maritime Law and Commerce. 48 (2017) No. 2: 103.

1595 ELLIOTT, Lorraine. Cooperation on Transnational Environmental Crime: Institutional Complexity Matters. Review of European Comparative and International Environmental Law. 26 (2017) No. 2: 107.

1596 EPSTEIN, Yaffa. Killing Wolves to Save Them? Legal Responses to 'Tolerance Hunting' in the European Union and United States. Review of European Comparative and International Environmental Law. 26 (2017) No. 1: 19.

1597 FASOLI, Elena. Review and Adjustment Under the UN-ECE Transboundary Air Pollution Treaty Regimes and the Implementing EU Legislation. European Energy and Enviromental Law Review. 26 (2017) No. 5: 130.

1598 FASOLI, Elena. The Possibilities for Nongovernmental Organizations Promoting Environmental Protection to Claim Damages in Relation to the Environment in France, Italy, the Netherlands and Portugal. Review of European Comparative and International Environmental Law. 26 (2017) No. 1: 30.

1599 FAURE, Michael. The Development of Environmental Criminal Law in the EU and its Member States. Review of European Comparative and International Environmental Law. 26 (2017) No. 2: 139.

1600 FOSTER, Caroline E. Respecting Regulatory Measures: Arbitral Method and Reasoning in the Philip Morris v Uruguay Tobacco Plain Packaging Case. Review of European, Comparative \& International Environmental Law. 26 (2017) No. 3: 287.

1601 GEEBELEN, Brecht. Ability of EU Legislation to Deter: The Volkswagen Case. European Energy and Enviromental Law Review. 26 (2017) No. 4: 102.

1602 GEYSENS, Junior. Capacity Mechanisms after the Commission's Winter Package. European Energy and Enviromental Law Review. 26 (2017) No. 4: 111.

1603 GILJAM, Renske A. Better BAT to Bolster Ecosystem Resilience: Operationalizing Ecological Governance through the Concept of Best Available Techniques. Review of European Comparative and International Environmental Law. 26 (2017) No. 1: 5 .

1604 GOLLATA, Judith A.M.; Newig, Jens. Policy Implementation through Multi-Level Governance: Analysing Practical Implementation of EU Air Quality Directives in Germany. Journal of European Public Policy. 24 (2017) No. 9: 1308.

1605 GONZALEZ ARREAZA, Alejandro. Natural Resource Sovereignty and Economic Development in the WTO in Light of the Recent Case Law Involving Raw Materials and Rare Earths. Review of European, Comparative \& International Environmental Law. 26 (2017) No. 3: 266. 
1606 KAIME, Thoko. Countering Abuse in EU Environmental Markets: The Case for Integrated Operational Safeguards. Review of European Comparative and International Environmental Law. 26 (2017) No. 1: 69.

1607 KARAGEORGOU, Vasiliki (Vicky). The EU Regulatory Framework to Deal with the Environmental Effects of the Mining Activities - Assessing the Effectiveness. European Energy and Enviromental Law Review. 25 (2016) No. 5: 138.

1608 KOPELA, Sophia. Making Ships Cleaner: Reducing Air Pollution from International Shipping. Review of European, Comparative \& International Environmental Law. 26 (2017) No. 3: 231.

1609 LAWRENCE, Peter; Wong, Daryl. Soft law in the Paris Climate Agreement: Strength or Weakness? Review of European Comparative and International Environmental Law. 26 (2017) No. 3: 276.

1610 LIEFFERINK, Duncan; Wurzel, Rüdiger K.W. Environmental Leaders and Pioneers: Agents of Change? Journal of European Public Policy. 24 (2017) No. 7: 951.

1611 LYNGGAARD, Kennet. Exploring the Emotional Appeal of Green and Social Europe Myths among Pan-European Union Organizations. Journal of European Public Policy. 24 (2017) No. 10: 1409.

1612 MAGUIRE, Amy; McGee, Jeffrey. A Universal Human Right to Shape Responses to a Global Problem? The Role of Self-Determination in Guiding the International Legal Response to Climate Change. Review of European Comparative and International Environmental Law. 26 (2017) No. 1: 54.

1613 MALINAUSKAITE, J.; Jouhara, H.; Spencer, N. Waste Prevention and Technologies in the Context of the EU Waste Framework Directive: Lost in Translation? European Energy and Enviromental Law Review. 26 (2017) No. 3: 66.

1614 PARKER, Charles F.; Karlsson, Christer; Hjerpe, Mattias. Assessing the European Union's Global Climate Change Leadership: From Copenhagen to the Paris Agreement. Journal of European Integration. 39 (2017) No. 2: 239.

1615 PEREIRA, Ricardo. Towards Effective Implementation of the EU Environmental Crime Directive? The Case of Illegal Waste Management and Trafficking Offences. Review of European Comparative and International Environmental Law. 26 (2017) No. 2: 147.

1616 PERILONGO, Giovanni F.; Corn, Emanuele. The Ecocrime Directive and its Translation into Legal Practice. EU Green Offences and their Impact at National Level According to the Results of a Recent Survey. New Journal of European Criminal Law. 8 (2017) No. 2: 236.

1617 PIGUET, Frédéric-Paul [et al.]. Recycling and Utilisation of Carbon Dioxide in the European Union's Directives. European Energy and Enviromental Law Review. 26 (2017) No. 1:2.

1618 PONCIBÒ, Cristina. The Contractualisation of Environmental Sustainability. European Review of Contract Law. 12 (2016) No. 4: 335.

1619 ROBERTS, Mark W. Finishing the Job: The Montreal Protocol Moves to Phase Down Hydrofluorocarbons. Review of European Comparative and International Environmental Law. 26 (2017) No. 3: 220.

1620 ROSE, Gregory. Australian Law to Combat Illegal Logging in Indonesia: A Gossamer Chain for Transnational Enforcement of Environmental Law. Review of European Comparative and International Environmental Law. 26 (2017) No. 2: 128.

1621 SÁNCHEZ GALERA, María Dolores. The Integration of Energy and Environment under the Paradigm of Sustainability threatened by the Hurdles of the Internal Energy Market. European Energy and Enviromental Law Review. 26 (2017) No. 1: 13. 
1622 SAND, Peter H. The Discourse on 'Protection of the Atmosphere' in the International Law Commission. Review of European, Comparative \& International Environmental Law. 26 (2017) No. 3: 201.

1623 SCHOUKENS, Hendrik. Articles 9(3) and 9(4) of the Aarhus Convention and Access to Justice before EU Courts in Environmental Cases: Balancing On or Over the Edge of Non-Compliance? European Energy and Enviromental Law Review. 25 (2016) No. 6: 178.

1624 SIMÕES, Fernando Dias. Blusun S.A. and Others v Italy: Legal (In)stability and Renewable Energy Investments. Review of European Comparative and International Environmental Law. 26 (2017) No. 3: 298.

1625 SOWERY, Katy. Reconciling Primacy and Environmental Protection: Association France Nature Environnement. Common Market Law Review. 54 (2017) No. 4: 1157.

1626 STEINEBACH, Yves; Knill, Christoph. Still an Entrepreneur? The Changing Role of the European Commission in EU Environmental Policy-Making. Journal of European Public Policy. 24 (2017) No. 3: 429.

1627 VAN DOORN-HOEKVELD, Wollemijn. Transboundary Flood Risk Management: Compatibilities of the Legal Systems of Flood Risk Management in the Netherlands, Flanders and France - A Comparison. European Energy and Enviromental Law Review. 26 (2017) No. 3: 81.

1628 VERSCHUUREN, Jonathan. Does Environmental Law Encourage Obstruct EcoInnovations? Evidence from Case Studies in the Netherlands. European Energy and Enviromental Law Review. 26 (2017) No. 2: 51.

1629 YAMINEVA, Yulia; Romppanen, Seita. Is Law Failing to Address Air Pollution? Reflections on International and EU Developments. Review of European, Comparative \& International Environmental Law. 26 (2017) No. 3: 189.

1630 ZULUAGA MADRID, Juliana. Access to Environmental Information from Private Entities: A Rights-Based Approach. Review of European Comparative and International Environmental Law. 26 (2017) No. 1: 38.

12 Consumer affairs

(Safety of products and services / Product safety / Advertising / Labelling / Consumer rights / Financial protection / Food issues)

1631 APPENZELLER, Carmen. Towards a More Effective Regulation of Unfair Standard Contract Terms in Europe: Of Cartels, Watchdogs and a 'Gorilla in the Closet'. Journal of European Consumer and Market Law. 6 (2017) No. 2: 60.

1632 BAIRATI, Lorenzo. The Food Consumer's Right to Information on Product Country of Origin: Trends and Outlook, beyond EU Regulation 1169/2011. Journal of European Consumer and Market Law. 6 (2017) No. 1: 9.

1633 BARTOLINI, Francesca. The Consumer-Debtor Dimension: Some Further Steps for the Principle of Effectiveness within Consumer Credit Contracts. European Review of Contract Law. 12 (2016) No. 3: 292.

1634 BUSCH, Christoph; Mak, Vanessa. Peer-to-Peer Lending in the European Union. Journal of European Consumer and Market Law. 5 (2016) No. 4: 181.

1635 CAFAGGI, Fabrizio; Iamiceli, Paola. The Principles of Effectiveness, Proportionality and Dissuasiveness in the Enforcement of EU Consumer Law: The Impact of a Triad on the Choice of Civil Remedies and Administrative Sanctions. European Review of Private Law. 25 (2017) No. 3: 575.

1636 CAINE, Catherine Ann. 'Dieselgate' and Consumer Law: Repercussions of the Volkswagen Scandal in the United Kingdom. Journal of European Consumer and Market Law. 6 (2017) No. 2: 85. 
1637 CANTERO GAMITO, Marta. Dispute Resolution in Telecommunications: A Commitment to Out-of-Court. European Review of Private Law. 25 (2017) No. 2: 387.

1638 CAUFFMAN, Caroline. The Commission's European Agenda for the Collaborative Economy - (Too) Platform and Service Provider Friendly? Journal of European Consumer and Market Law. 5 (2016) No. 6: 235.

1639 CHUNG, Gordon. A Comparative Analysis of the Frustration Rule: Possibility of Reconciliation Between Hong Kong-English 'Hands-off Approach' and German 'Interventionist Mechanism'. European Review of Private Law. 25 (2017) No. 1: 109.

1640 CREUTZFELDT, Naomi. Implementation of the Consumer ADR Directive. Journal of European Consumer and Market Law. 5 (2016) No. 4169.

1641 DE BELVIS, Elisa. Delivery, Property and Risk in the Law of Sale. European Review of Contract Law. 13 (2017) No. 1: 38.

1642 DE BRUYNE, Jan; Vanleenhove, Cedric. Liability in the Medical Sector: The 'Breast-Taking' Consequences of the Poly Implant Prothèse Case. European Review of Private Law. 24 (2016) No. 5: 823.

1643 DE ELIZALDE, Francisco. Advertising as a Source of Terms - At the Crossroads between Contract and Consumer Law. Journal of European Consumer and Market Law. 6 (2017) No. 2: 80.

1644 DE ELIZALDE, Francisco. Should the Implied Term Concerning Quality Be Generalized? Present and Future of the Principle of Conformity in Europe. European Review of Private Law. 25 (2017) No. 1: 71.

1645 DE MUYNCK, Michiel; Bruloot, Diederik. Credit Intermediation under the 2014 European Mortgage Credit Directive: A Call for Targeted Rules on Intermediary Remuneration. European Review of Contract Law. 13 (2017) No. 1: 1.

1646 DUIVENVOORDE, Bram. The CJEU Decision in Citroën/ZLW: Ready for REFIT? Journal of European Consumer and Market Law. 6 (2017) No. 2: 77.

1647 DYBUS, Charles; Lemmen, Jeroen. 'Dieselgate' and Consumer Law: Repercussions of the Volkswagen Scandal in the Netherlands. Journal of European Consumer and Market Law. 6 (2017) No. 2: 91.

1648 ESTEVAN DE QUESADA, Carmen; Renner, Moritz. Contractual Business Networks: The Case of Syndicated Loans. European Review of Contract Law. 13 (2017) No. 2: 164.

1649 FABBIO, Philipp. 'Dieselgate' and Consumer Law: Repercussions of the Volkswagen Scandal in Italy. Journal of European Consumer and Market Law. 6 (2017) No. 2: 94.

1650 FAZEKAS, Judit. The Consumer Credit Crisis and Unfair Contract Terms Regulation - Before and After Kásler. Journal of European Consumer and Market Law. 6 (2017) No. 3: 99.

1651 FERNÁNDEZ CARBALlO-CALERO, Pablo. Aggressive Commercial Practices in the Case Law of EU Member States. Journal of European Consumer and Market Law. 5 (2016) No. 6: 251.

1652 FERRETTI, F. The Over-Indebted European Consumers: Quo Vadis Personal Insolvency Law? European Law Review. 41 (2016) No. 6: 843.

1653 GEELHOED, Miranda. Divided in Diversity: Reforming The EU's GMO Regime. Cambridge Yearbook of European Legal Studies. 18 (2016): 20.

1654 GRUNDMANN, Stefan; Hacker, Philipp. Digital Technology as a Challenge to European Contract Law. European Review of Contract Law. 13 (2017) No. 3: 255. 
1655 GRUŠIĆ, Uglješa. Long-Term Business Relationships and Implicit Contracts in European Private Law. European Review of Contract Law. 12 (2016) No. 4: 395.

1656 HEIRMAN, Glenn. Core Terms: Interpretation and Possibilities of Assessment. Journal of European Consumer and Market Law. 6 (2017) No. 1: 30.

1657 HELlERINGER, Genevieve; Sibony, Anne-Lise. European Consumer Protection through the Behavioral Lens. Columbia Journal of European Law. 23 (2017) No. 3: 607.

1658 JÓZON, Mónika. Unfair Contract Terms Law in Europe in Times of Crisis: Substantive Justice Lost in the Paradise of Proceduralisation of Contract Fairness. Journal of European Consumer and Market Law. 6 (2017) No. 4: 157.

1659 JULL SøRENSEN, Marie. In the Name of Effective Consumer Protection and Public Policy! European Review of Private Law. 24 (2016) No. 5: 791.

1660 KNIGGE, Marte; Pavillon, Charlotte. The Legality Requirement of the ADR Directive: Just Another Paper Tiger? Journal of European Consumer and Market Law. 5 (2016) No. 4: 155.

1661 KOHUTEK, Konrad. Resale Price Maintenance in Franchising: Hardcore Restriction of Competition or Necessary Element of Such Business Model? Journal of European Consumer and Market Law. 6 (2017) No. 4: 167.

1662 KOMNIOS, Komninos. The Implementation of the Consumer ADR Directive in Greece. Journal of European Consumer and Market Law. 5 (2016) No. 6: 244.

1663 KRACHLER, Christian; Rzehorska, Martin. 'Dieselgate' and Consumer Law: Repercussions of the Volkswagen Scandal in Austria. Journal of European Consumer and Market Law. 6 (2017) No. 1: 36.

1664 LAW, Stephanie. At the Crossroads of Consumer Protection, Data Protection and Private International Law: Some Remarks on Verein fur Konsumenteninformation v Amazon EU. European Law Review. 42 (2017) No. 5: 751.

1665 LOOS, Marco. Double Dutch - On the Role of the Transparency Requirement with Regard to the Language in which Standard Contract Terms for B2C-Contracts must be Drafted. Journal of European Consumer and Market Law. 6 (2017) No. 2: 54.

1666 LUZAK, Joasia. You Too Will be Judged: Erga Omnes Effect of Registered Unfair Contract Terms in Poland. Journal of European Consumer and Market Law. 6 (2017) No. 3: 120 .

1667 MARQUES CEBOLA, Cátia; Conceição, Ana Filipa. Consumer Financial Services and Negotiation: How is Portugal Dealing with Indebted Consumers? Journal of European Consumer and Market Law. 5 (2016) No. 5: 211.

1668 MEZZANOTE, Francesco. Regulation of Business-Clients Relationships through 'Organisational Law'. European Review of Contract Law. 13 (2017) No. 2: 123.

1669 MONTESINOS GARCÍA, Ana. The Potential Implementation of Collective Arbitration in Europe. European Review of Private Law. 25 (2017) No. 2: 363.

1670 MÜllER, Michael F. Amazon and Data Protection Law - The End of the Private/ Public Divide in EU Conflict of Laws? Journal of European Consumer and Market Law. 5 (2016) No. 5: 215.

1671 NAMYSŁOWSKA, Monika. 'Dieselgate' and Consumer Law: Repercussions of the Volkswagen Scandal in Poland. Journal of European Consumer and Market Law. 6 (2017) No. 2: 87.

1672 NARCISO, Madalena. 'Gratuitous' Digital Content Contracts in EU Consumer Law. Journal of European Consumer and Market Law. 6 (2017) No. 5: 198.

1673 NEMETH, Kristin. How Much Can a Credit Cost? Recent Developments in Unfair Terms and Consumer Credit Law in Austria and Germany. Journal of European Consumer and Market Law. 5 (2016) No. 6: 262. 
1674 NEMETH, Kristin; Morais Carvalho, Jorge. 'Dieselgate' and Consumer Law: Repercussions of the Volkswagen Scandal in the European Union. Journal of European Consumer and Market Law. 6 (2017) No. 1: 35.

1675 OLIVIERO, Francesco. EU Case Law: Intermediary and Concept of 'Seller' in the Sale of Goods. European Review of Contract Law. 13 (2017) No. 2: 219.

1676 PACHECO JIMÉNEZ, María Nieves. Payment Services Evolution: From the European Directive of 2007 to the Digital Single Market and the European Directive of 2015. Journal of European Consumer and Market Law. 5 (2016) No. 5: 219.

1677 PASSINHAS, Sandra. 'Dieselgate' and Consumer Law: Repercussions of the Volkswagen Scandal in Portugal. Journal of European Consumer and Market Law. 6 (2017) No. 1: 42.

1678 PATTI, Francesco Paolo. 'Fraud' and 'Misleading Commercial Practices': Modernising the Law of Defects in Consent. European Review of Contract Law. 12 (2016) No. 4: 307.

1679 PERTOT, Tereza; D’Onofrio, Martina. Platforms - Business Models and Contracts. Journal of European Consumer and Market Law. 6 (2017) No. 4: 170.

1680 PORMEISTER, Kärt. Informed Consent to Sensitive Personal Data Processing for the Performance of Digital Consumer Contracts on the Example of '23andMe'. Journal of European Consumer and Market Law. 6 (2017) No. 1: 17.

1681 RIEFA, Christine. G20 Consumer Summit on Building a Digital World Consumers Can Trust. Journal of European Consumer and Market Law. 6 (2017) No. 3: 124.

1682 RIEHM, Thomas; Lindner, Lukas. 'Dieselgate' and Consumer Law: Repercussions of the Volkswagen Scandal in Germany. Journal of European Consumer and Market Law. 6 (2017) No. 1: 39.

1683 ROTT, Peter. Data Protection Law as Consumer Law - How Consumer Organisations Can Contribute to the Enforcement of Data Protection Law. Journal of European Consumer and Market Law. 6 (2017) No. 3: 113.

1684 SAGAERT, Vincent; Gruyaert, Dorothy. Retention of Title or the Transfer of Ownership in a Slideway: Ownership in Adultery? European Review of Private Law. 25 (2017) No. 2: 421.

1685 SANTAMARÍA, Enrique. Contracts on Human Biological Samples: The European Prohibition of Financial Gain from the Human Body and its Parts. European Review of Contract Law. 13 (2017) No. 2: 195.

1686 SCHAUB, Martien. How to Make the Best of Mandatory Information Requirements in Consumer Law. European Review of Private Law. 25 (2017) No. 1: 25.

1687 SEIN, Karin. A Consumer's Right to a Free Paper Bill in Mobile Phone Contracts. Journal of European Consumer and Market Law. 6 (2017) No. 1: 3

1688 SEIN, Karin. The Draft Geoblocking Regulation and its Possible Impact on B2C Contracts. Journal of European Consumer and Market Law. 6 (2017) No. 4: 148.

1689 SELUCKÁ, Markéta [et al.]. Selected Sociological and Legal Aspects of Consumer Protection in the Czech Republic. Journal of European Consumer and Market Law. 6 (2017) No. 1: 24.

1690 SIMON, Rita. Transposition of the Mortgage Credit Directive into Hungarian and Czech law - The Problem of Credit Intermediaries. Journal of European Consumer and Market Law. 6 (2017) No. 3: 106.

1691 STAFF, Natalie. Consumer Protection in Mortgage Lending. European Journal of Comparative Law and Governance. 3 (2016) No. 4: 385 pp.

1692 STORME, Matthias E. Revealing Underlying Tensions: Contracts and Other Dialogues. European Review of Private Law. 25 (2017) No. 1: 1. 
1693 STRAETMANS, Gert. Misleading Practices, the Consumer Information Model and Consumer Protection. Journal of European Consumer and Market Law. 5 (2016) No. 5: 199 .

1694 TERESKIEWICZ, Piotr. The Reform of Polish Sales Law - Re-implementing the Consumer Sales Directive. Journal of European Consumer and Market Law. 5 (2016) No. 4: 175 .

1695 TUDELA-MARCO, Lorena [et al.]. Do EU Member States Apply Food Standards Uniformly? A Look at Fruit and Vegetable Safety Notifications. Journal of Common Market Studies. 55 (2017) No. 2: 387.

1696 TWIGG-FLESNER, Christian. From REFIT to a Rethink: Time for Fundamental EU Consumer Law Reform? Journal of European Consumer and Market Law. 6 (2017) No. 5: 185 .

1697 VAN DUIN, Anna. Metamorphosis? The Role of Article 47 of the EU Charter of Fundamental Rights in Cases Concerning National Remedies and Procedures under Directive 93/13/EEC. Journal of European Consumer and Market Law. 6 (2017) No. 5: 190

1698 VAN SCHAGEN, Esther. Better Regulation and the Principle of Consumer Protection in EU Contract Law. European Review of Contract Law. 13 (2017) No. 3: 239 .

1699 VOLENS, Urmas; Lilleholt, Kåre. Consumer Insolvency Law in Estonia and Norway: Comparative Aspects. European Review of Private Law. 24 (2016) No. 5: 759.

1700 WEBER, Rolf H. Liability in the Internet of Things. Journal of European Consumer and Market Law. 6 (2017) No. 5: 207.

1701 WRBKA, Stefan. Warranty Law in Cases of Planned Obsolescence - The Austrian Situation. Journal of European Consumer and Market Law. 6 (2017) No. 2: 67.

1702 ZOLL, Fryderyk. The Remedies in the Proposals of the only Sales Directive and the Directive on the Supply of Digital Content. Journal of European Consumer and Market Law. 5 (2016) No. 6: 250.

1703 ZUPANCIC, Neza; Havu, Katri. Pre-Installed Software - An Unfair Commercial Practice (Case Note). Maastricht Journal of European and Comparative Law. 24 (2017) No. 2: 289.

13 Agriculture - Fisheries - Forestry

(Common Agricultural Policy / Animal health / Plant health / Farming methods / Agricultural markets)

1704 ALONS, Gerry. Environmental Policy Integration in the EU's Common Agricultural Policy: Greening or Greenwashing? Journal of European Public Policy. 24 (2017) No. 11: 1604.

1705 DAUGBJERG, Carsten. Responding to Non-Linear Internationalisation of Public Policy: The World Trade Organization and Reform of the CAP 1992-2013. Journal of Common Market Studies. 55 (2017) No. 3: 486.

1706 DAUGBJERG, Carsten; Aurvåg Farsund, Arild; Langhelle, Oluf. The Resilience of Paradigm Mixes: Food Security in a Post-Exceptionalist Trade Regime. Journal of European Public Policy. 24 (2017) No. 11: 1698.

1707 DAUGBJERG, Carsten; Feindt, Peter H. Post-Exceptionalism in Public Policy: Transforming Food and Agricultural Policy. Journal of European Public Policy. 24 (2017) No. 11: 1565.

1708 DOBBS, Mary. Genetically Modified Crops, Agricultural Sustainability and National Opt-Outs: Enclosure as the Loophole? Common Market Law Review. 54 (2017) No. 4: 1093. 
1709 DRIESSEN, Bart. Fundamental Animal Rights in European Law. European Public Law. 23 (2017) No. 3: 547.

1710 DUBNER, Barry Hart; Vargas, Loany M. On the Law of Pirate Fishing and Its Connection to Human Rights Violations and to Environmental Degradation - A Multi-National Disaster. Journal of Maritime Law and Commerce. 48 (2017) No. 2: 103.

1711 FOUILlEUX, Eve; Bricas, Nicolas; Alpha, Arlène. 'Feeding 9 Billion People': Global Food Security Debates and the Productionist Trap. Journal of European Public Policy. 24 (2017) No. 11: 1658.

1712 GREER, Alan. Post-Exceptional Politics in Agriculture: An Examination of the 2013 CAP Reform. Journal of European Public Policy. 24 (2017) No. 11: 1585.

1713 GRÜNER, Hans Peter; Muller, Daniel. Measuring Political Information Rents: Evidence from the European Agricultural Reform. European Journal of Political Economy. (2016) No. 43: 107.

1714 JONES, Philip; Lensink, Joop; Mancini, Maria Cecilia. Designing an Institutional Network for Improving Farm Animal Welfare in the EU. Journal of Common Market Studies. 55 (2017) No. 5: 1081.

1715 MEDINA, Gabriel; Potter, Clive. The Nature and Developments of the Common Agricultural Policy: Lessons for European Integration from the UK Perspective. Journal of European Integration. 39 (2017) No. 4: 373.

1716 PURNHAGEN, Kai Peter; Feindt, Peter. Principles-Based Regulation: Blueprint for a 'New Approach' for the Internal Agricultural Market. European Law Review. 42 (2017) No. 5: 722 .

1717 PURNHAGEN, Kai Peter; Schebesta, Hanna. A Case at the Frontiers of Market Access, Freedom of Goods, the Common Agricultural Policy and Science in Court: Reflections on Scotch Whisky Association. European Law Review. 42 (2017) No. 3: 420.

1718 SCHWINDENHAMMER, Sandra. Global Organic Agriculture Policy-Making through Standards as an Organizational Field: When Institutional Dynamics Meet Entrepreneurs. Journal of European Public Policy. 24 (2017) No. 11: 1678.

1719 SHEINGATE, Adam; Scatterday, Allysan; Martin, Bob; Nachman, Keeve. PostExceptionalism and Corporate Interests in US Agricultural Policy. Journal of European Public Policy. 24 (2017) No. 11: 1641.

1720 TOSUN, Jale. Party Support for Post-Exceptionalism in Agri-Food Politics and Policy: Germany and the United Kingdom Compared. Journal of European Public Policy. 24 (2017) No. 11: 1623.

1721 ZIMMERMANN, Hubert. Balancing Sustainability and Commerce in International Negotiation: The EU and its Fisheries Partnership Agreements. Journal of European Public Policy. 24 (2017) No. 1: 135.

\section{Transport}

(Urban/Rural transport / Railways / Roads / Inland waterways / Sea transport / Ports / Air transport / Multimodal transport / Tourism)

1722 ABEYRATNE, Ruwantissa. Outcome of the 39th Session of the International Civil Aviation Organization Assembly. Air \& Space Law. 42 (2017) No. 1: 13

1723 AIT-MLOUK, Addi; Gharnati, Fatima; Agouti, Tarik. An Improved Approach for Association Rule Mining Using a Multi-Criteria Decision Support System: A Case Study in Road Safety. European Transport Research Review. 9 (2017) No. 3: 40 pp. 
1724 ANUND, Anna; Fors, Carina; Ahlstrom, Christer. The Severity of Driver Fatigue in Terms of Line Crossing: A Pilot Study Comparing Day- and Night Time Driving in Simulator. European Transport Research Review. 9 (2017) No. 2: 31 pp.

1725 ARNOLD, Iván; Papp, Zoltán; Arnold, Kinga. The Difficult Present and Uncertain Future of the Single European Sky Network Manager: The Challenges We Are Facing and Why They Matter. Air \& Space Law. 42 (2017) No. 2: 185.

1726 BALFOUR, John; van der Wijngaart, Tom. Montreal Convention: To Whom Is the Carrier Liable in the Event of Delay? Air \& Space Law. 41 (2016) No. 6: 511.

1727 BASARAN, Ilker. The Future of Arctic Navigation: Cooperation between the International Maritime Organization and Arctic Council. Journal of Maritime Law and Commerce. 48 (2017) No. 1: 35.

1728 BLANQUART, Corinne; Koning, Martin. The Local Economic Impacts of HighSpeed Railways: Theories and Facts. European Transport Research Review. 9 (2017) No. 2: 12 pp.

1729 BLOUNT, P. J. Satellites Are Just Things on the Internet of Things. Air \& Space Law. 42 (2017) No. 3: 273.

1730 BRECKE, Katja H. Steef Mennens v. Emirates Direktion für Deutschland. Air \& Space Law. 42 (2017) No. 1: 71.

1731 BULDEO RAI, Heleen [et al.]. Crowd Logistics: An Opportunity for More Sustainable Urban Freight Transport? European Transport Research Review. 9 (2017) No. 3: 39 pp.

1732 CARPANELli, Elena; Lazzerini, Nicole. PNR: Passenger Name Record, Problems Not Resolved? The EU PNR Conundrum After Opinion 1/15 of the CJEU. Air \& Space Law. 42 (2017) No. 4/5: 377.

1733 CASCAJO, Rocio; Garcia-Martinez, Andres; Monzon, Andres. Stated Preference Survey for Estimating Passenger Transfer Penalties: Design and Application to Madrid. European Transport Research Review. 9 (2017) No. 3: 42 pp.

1734 CHALLINOR, Chloe A.S. Accident Investigators Are the Guardians of Public Safety: The Importance of Safeguarding the Independence of Air Accident Investigations as Illustrated by Recent Accidents. Air \& Space Law. 42 (2017) No. 1: 43.

1735 CONDEÇO-MELHORADO, Ana; Geurs, Karst T. Topical Collection on Accessibility and Policy Making. European Transport Research Review. 9 (2017) No. 3: 33 pp.

1736 COSTABEL, Attilio M. Utmost Good Faith in Marine Insurance: A Message on the State of the Dis-Union. Journal of Maritime Law and Commerce. 48 (2017) No. 1: 1.

1737 COX ORME, Kylie. Guardians of the Galaxy: How Space Tourism Regulation Will Shape Telehealth. Air \& Space Law. 42 (2017) No. 2: 163.

1738 DALLA CHIARA, Giacomo; Cheah, Lynette. Data Stories from Urban Loading Bays. European Transport Research Review. 9 (2017) No. 4: 50 pp.

1739 DEASY, Geoffrey. European Union Competition Law Developments in the Aviation Sector: January to June 2016. Air \& Space Law. 41 (2016) No. 6: 517.

1740 DIAO, Weimin; Zhang, Chrystal. Incorporation of International Aviation Security Conventions into China's Legislation: Further Integration Is Needed for Effective Implementation. Air \& Space Law. 42 (2017) No. 3: 247.

1741 EBENDT, Rüdiger; Touko Tcheumadjeu, Louis Calvin. An Approach to GeometryBased Dynamic Location Referencing. European Transport Research Review. 9 (2017) No. 3: 38 pp.

1742 EFTHYMIOU, Dimitrios; Chrysostomou, Katerina; Morfoulaki, Maria; Aifantopoulou, Georgia. Electric Vehicles Charging Infrastructure Location: A Genetic Algorithm Approach. European Transport Research Review. 9 (2017) No. 2: 27 pp. 
1743 EMBERGER, Guenter. National Transport Policy in Austria -- from its Beginning Till Today. European Transport Research Review. 9 (2017) No. 1: 6 pp.

1744 EMBERGER, Günter; May, Anthony D. Challenges in the Development of National Policies on Transport. European Transport Research Review. 9 (2017) No. 4: 55 pp.

1745 ERLING, Uwe M. International Aviation Emissions Under International Civil Aviation Organization's Global Market Based Measure: Ready for Offsetting? Air \& Space Law. 42 (2017) No. 1: 1.

1746 ERTEM, Mustafa Alp [et al.]. Review of Intermodal Freight Transportation in Humanitarian Logistics. European Transport Research Review. 9 (2017) No. 1: 10 pp.

1747 FICHERT, Frank. Transport Policy Planning in Germany - An Analysis of Political Programs and Investment Masterplans. European Transport Research Review. 9 (2017) No. 2: $28 \mathrm{pp}$.

1748 FOSSHEIM, Karin; Andersen, Jardar. Plan for Sustainable Urban Logistics -Comparing between Scandinavian and UK Practices. European Transport Research Review. 9 (2017) No. 4: 52 pp.

1749 FOX, Sarah Jane; Rosida, Ismail. The Skies the Limit: Open Skies - With Limitations. European Journal of Comparative Law and Governance. 4 (2017) No. 1: $7 \mathrm{pp}$.

1750 FREEMAN, Paul; Tang, Melissa; Chong, Lau Chee. Lightning Doesn't Strike Twice: The Tragedy and Challenges of the MH370 and MH17 Losses. Air \& Space Law. 42 (2017) No. 4/5: 423.

1751 GAC, Maciej; Bernatt, Maciej. Rail Freight: How Does Poland Assesses Alleged Abuses by Dominant Firms. Journal of European Competition Law and Practice. 8 (2017) No. 6: 388.

1752 GATTA, Valerio; Marcucci, Edoardo; Le Pira, Michela. Smart Urban Freight Planning Process: Integrating Desk, Living Lab and Modelling Approaches in DecisionMaking. European Transport Research Review. 9 (2017) No. 3: 32 pp.

1753 GAUCI, Gotthard Mark. Is It a Vessel, a Ship or a Boat, Is It Just a Craft, or Is It Merely a Contrivance. Journal of Maritime Law and Commerce. 47 (2016) No. 4: 479.

1754 GOLD, Megen. And Justice for All: An Analysis of a Shipowner's Duty of Care in Piracy and Armed Robbery Attacks. Journal of Maritime Law and Commerce. 47 (2016) No. 4: 501 .

1755 HARRISON, Gillian; Thiel, Christian. Policy Insights and Modelling Challenges: The Case of Passenger Car Powertrain Technology Transition in the European Union. European Transport Research Review. 9 (2017) No. 3: 37 pp.

1756 HOUVARDAS, Dimitris. Charterers and Vetting: Balancing between Freedom and Nightmare. Journal of Maritime Law and Commerce. 48 (2017) No. 2: 183.

1757 HULSROJ, Peter; Nakarada Pecujlic, Anja. New in the Nest: The Danish Space Act. Air \& Space Law. 41 (2016) No. 6: 503.

1758 HUTTUNEN, Mikko. Unmanned, Remotely Piloted, or Something Else? Analysing the Terminological Dogfight. Air \& Space Law. 42 (2017) No. 3: 349.

1759 ISLAM, Dewan Md Zahurul; Blinge, Magnus. The Future of European Rail Freight Transport and Logistics. European Transport Research Review. 9 (2017) No. 1: 11 pp.

1760 JARVIS, Robert M. The Sailor, the Prostitute, the Pimp, and the Judge: Chasing down the Loose Ends of Koistinen v. American Export Lines, Inc. Journal of Maritime Law and Commerce. 48 (2017) No. 3: 243. 
1761 JEEKEL, J.F.; Martens, C. J. C. M. Equity in Transport: Learning from the Policy Domains of Housing, Health Care and Education. European Transport Research Review. 9 (2017) No. 4: 53 pp.

1762 JOHNSON, Eric. Cars and Ground-Level Ozone: How do Fuels Compare? European Transport Research Review. 9 (2017) No. 4: 47 pp.

1763 KASPRZYK, Piotr; Konert, Anna. Prohibition to Hear Safety Investigators: The Supreme Court of Poland Judgment of 27 April 2015. Air \& Space Law. 42 (2017) No. 4/5: 487.

1764 KILPATRICK, Richard L. Jr. The Joint and Several Liability of Merchants under Maritime Bills of Lading. Journal of Maritime Law and Commerce. 47 (2016) No. 4: 411.

1765 KRMAC, Evelin; Djordjević, Boban. An Evaluation of Train Control Information Systems for Sustainable Railway Using the Analytic Hierarchy Process (AHP) Model. European Transport Research Review. 9 (2017) No. 3: 35 pp.

1766 LANGLADE, Joanna. Noise Restriction Measures and the 'Balanced Approach': The Situation at Brussels-National Airport. Air \& Space Law. 42 (2017) No. 3: 313.

1767 LE PIRA, Michela [et al.]. Towards a Decision-Support Procedure to Foster Stakeholder Involvement and Acceptability of Urban Freight Transport Policies. European Transport Research Review. 9 (2017) No. 4: 54 pp.

1768 LI, Ye; Yu, Yuewu. The Use of Freight Apps in Road Freight Transport for CO2 Reduction. European Transport Research Review. 9 (2017) No. 3: 36 pp.

1769 MALINOWSKA, Katarzyna. Risk Assessment in Insuring Space Endeavours: A Legal Approach. Air \& Space Law. 42 (2017) No. 3: 329.

1770 MALONE, Kerry; Silla, Anne; Johanssen, Charlotta; Bell, Daniel. Safety, Mobility and Comfort Assessment Methodologies of Intelligent Transport Systems for Vulnerable Road Users. European Transport Research Review. 9 (2017) No. 2: 21 pp.

1771 MAY, Anthony [et al.]. Appropriate National Policy Frameworks for Sustainable Urban Mobility Plans. European Transport Research Review. 9 (2017) No. 1: 7 pp.

1772 MELO, Sandra; Baptista, Patricia. Evaluating the Impacts of Using Cargo Cycles on Urban Logistics: Integrating Traffic, Environmental and Operational Boundaries. European Transport Research Review. 9 (2017) No. 2: 30 pp.

1773 MIGNOT, Dominique. Topical Collection on Human Factors and Safety. European Transport Research Review. 9 (2017) No. 3: 41 pp.

1774 ÖLÇER, F. Pinar. The Downing of MH17: Fact-Finding and Constructing a Legal Response. Air \& Space Law. 42 (2017) No. 2: 137.

1775 PITERA, Kelly [et al.]. The Complexity of Planning for Goods Delivery in a Shared Urban Space: A Case Study Involving Cyclists and Trucks. European Transport Research Review. 9 (2017) No. 3: 46 pp.

1776 REED, Jacob A. Cold War Treaties in a New World: The Inevitable End of the Outer Space and Antarctic Treaty Systems. Air \& Space Law. 42 (2017) No. 4/5: 463.

1777 REULEAUX, Matthias; Jakobsen, Morten I. Cape Town Convention and 'Qualifying Declarations': Analysis of Ratification Approach and Transaction Practice in Recent Contracting States (2015-2016)'. Air \& Space Law. 42 (2017) No. 4/5: 403.

1778 RONG, Pumin. Liability in Criminal and Private Law regarding Maritime Safety. Journal of Maritime Law and Commerce. 48 (2017) No. 1: 53.

1779 RUSSO, Francesco; Comi, Antonio. From the Analysis of European Accident Data to Safety Assessment for Planning: The Role of Good Vehicles in Urban Area. European Transport Research Review. 9 (2017) No. 1: 9 pp. 
1780 SCANLON, Zoe. Addressing the Pitfalls of Exclusive Flag State Jurisdiction: Improving the Legal Regime for the Protection of Submarine Cables. Journal of Maritime Law and Commerce. 48 (2017) No. 3: 295.

1781 SCHEBESTA, Hanna. Risk Regulation Through Liability Allocation: Transnational Product Liability and the Role of Certification. Air \& Space Law. 42 (2017) No. 2: 107.

1782 SCHOEnBAUM, Thomas J. The South China Sea Arbitration Decision and a Plan for Peaceful Resolution of the Disputes. Journal of Maritime Law and Commerce. 47 (2016) No. 4: 451.

1783 SCOTT, Benjamyn I.; Trimarchi, Andrea. The Digital Aviation Industry: A Balancing Act Between Cybersecurity and European Consumer Protection. Air \& Space Law. 42 (2017) No. 4/5: 443.

1784 STERZER, Lena. Does Competition in the Housing Market Cause Transport Poverty? Interrelations of Residential Location Choice and Mobility. European Transport Research Review. 9 (2017) No. 3: 45 pp.

1785 STROM, Martin. European Union Competition Law Developments in the Aviation Sector: July to December 2016. Air \& Space Law. 42 (2017) No. 2: 215.

1786 SUNDAHL, Mark J. Regulating Non-Traditional Space Activities in the United States in the Wake of the Commercial Space Launch Competitiveness Act. Air \& Space Law. 42 (2017) No. 1: 29.

1787 SUSILO, Yusak O.; Liu, Chengxi. Examining the Relationships between Individual's Time Use and Activity Participations with their Health Indicators. European Transport Research Review. 9 (2017) No. 2: 26 pp.

1788 TABORDA, Ashley. Airline Alliances: Justifying the Bureau's Intervention. Air \& Space Law. 41 (2016) No. 6: 475.

1789 TAYLOR, Nicholas B. [et al.]. Modelling Delay Saving through Pro-active Incident Management Techniques. European Transport Research Review. 9 (2017) No. 4: 48 pp.

1790 THOMPRON, Maurice; Cooper, James; Harman, Jess. The Search for MH370: Where Are We Now? Air \& Space Law. 41 (2016) No. 6: 459.

1791 VADEBY, Anna; Anund, Anna. Effectiveness and Acceptability of Milled Rumble Strips on Rural Two-Lane Roads in Sweden. European Transport Research Review. 9 (2017) No. 2: 29 pp.

1792 VANUMU, Lakshmi Devi; Ramachandra Rao K.; Tiwari, Geetam. Fundamental Diagrams of Pedestrian Flow Characteristics: A Review. European Transport Research Review. 9 (2017) No. 4: 49 pp.

1793 VETTOREL, Arianna. Global Positioning System Evidence in Court Proceedings and Privacy: The Case of Italy. Air \& Space Law. 42 (2017) No. 3: 295.

1794 VRBASKI, Lazar. Flying into the Unknown: The UK's Air Transport Relations with the European Union and Third Countries Following 'Brexit'. Air \& Space Law. 41 (2016) No. 6: 421.

1795 WHEELER, Joanne. The Consequences Post Referendum for the UK Satellite and Space Industry. Air \& Space Law. 41 (2016) No. 6: 445.

1796 ZEMBRI-MARY, Geneviève. Planning Transport Infrastructures in an Uncertain Context. Analysis and Limits to Contemporary Planning in France. European Transport Research Review. 9 (2017) No. 4: 51 pp.

1797 ZOURNATZI, Christina. A Comparative Study of International Maritime Conventions: Italian and Greek Perspectives. European Journal of Comparative Law and Governance. 4 (2017) No. 2: 176 pp. 
15 Energy

(Energy liberalisation / Trans-European Energy Networks / Solid fuels / Oil - Gas / Nuclear energy / Alternative energy sources / Electricity

1798 BAIN, Jessica; Chaban, Natalia. An Emerging EU Strategic Narrative? Twitter Communication During the EU's Sustainable Energy Week. Comparative European Politics. 15 (2017) No. 1: 135.

1799 BAIN, Jessica; Greenland, Bérengère; Knodt, Michèle. A Polyphonic Marketplace: Images of EU External Energy Relations in British, French and German Media Discourses. Comparative European Politics. 15 (2017) No. 1: 115.

1800 BERNACIAK, Magdalena; Lis, Aleksandra. Weak Labour, Strong Interests: Polish Trade Unions and the Integration of EU Energy and Service Markets. Journal of Common Market Studies. 55 (2017) No. 3: 432.

1801 CHABAN, Natalia; Knodt, Michèle; Verdun, Amy. 'Talking with' not 'Talking at'? Perceptions of the EU as a Global Normative Energy Actor in the Eyes of BRICS and EU 'Big 3'. Comparative European Politics. 15 (2017) No. 1: 1.

1802 CHEBAKOVA, Anastasia; Gulyaeva, Olga; Shaban, Tatsiana. Russia and EU Cooperation in Energy Policy - Sending and Receiving Messages? Comparative European Politics. 15 (2017) No. 1: 45.

1803 FIORAMONTI, Lorenzo. South Africa's Perceptions of the EU in Energy Governance: A Partner in Decline? Comparative European Politics. 15 (2017) No. 1: 99.

1804 GUIMARÃES, Carolina; Piefer, Nadine. Brazil: (Future) Green Energy Power and Strategic Partner for the EU? Comparative European Politics. 15 (2017) No. 1: 23.

1805 HERRANZ-SURRALLÉS, Anna. Energy Diplomacy under Scrutiny: Parliamentary Control of Intergovernmental Agreements with Third-Country Suppliers. West European Politics. 40 (2017) No. 1: 183.

1806 JOHNSTON, Angus; van Der Marel, Eva. How Binding are the EU's 'Binding' Renewables Targets? Cambridge Yearbook of European Legal Studies. 18 (2016): 176.

1807 KUSTOVA, Irina. Towards a Comprehensive Research Agenda on EU Energy Integration: Policy Making, Energy Security, and EU Energy Actorness. Journal of European Integration. 39 (2017) No. 1: 95.

1808 LAVRIJSSEN, Saskia. The Right to Participation for Consumers in the Energy Transition. European Energy and Enviromental Law Review. 25 (2016) No. 5: 152.

1809 PIGUET, Frédéric-Paul [et al.]. Recycling and Utilisation of Carbon Dioxide in the European Union's Directives. European Energy and Enviromental Law Review. 26 (2017) No. 1: 2.

1810 PliEgo SELIE, Alvaro A.J.; Brouwer, Onno W. The Commission's State Aid Control over Renewable Energy Stimulation Measures Reinforced. Maastricht Journal of European and Comparative Law. 23 (2016) No. 5: 890.

1811 PORINS, Kristians. EU Cross-Border Energy Investments in an International Legal Context: In Between the Commodity Transportation, Transmission Infrastructure and Competitive Exemption Policy. European Energy and Enviromental Law Review. 26 (2017) No. 2: 32.

1812 RENCKENS, Stefan; Skogstad, Grace; Mondou, Matthieu. When Normative and Market Power Interact: The European Union and Global Biofuels Governance. Journal of Common Market Studies. 55 (2017) No. 6: 1432.

1813 ROBINS, Nicole; Chakma, Tridevi. State Aid in Energy under the Spotlight: The Implications of the Hinkley Point Decison. European State Aid Law Quarterly. 15 (2016) No. 2: 247. 
1814 SÁNCHEZ GALERA, María Dolores. The Integration of Energy and Environment under the Paradigm of Sustainability threatened by the Hurdles of the Internal Energy Market. European Energy and Enviromental Law Review. 26 (2017) No. 1: 13.

1815 SKOGSTAD, Grace. Policy Feedback and Self-Reinforcing and Self-Undermining Processes in EU Biofuels Policy. Journal of European Public Policy. 24 (2017) No. 1: 21 .

1816 STODDARD, Edward. Tough Times, Shifting Roles: Examining the EU's Commercial Diplomacy in Foreign Energy Markets. Journal of European Public Policy. 24 (2017) No. 7: 1048.

1817 SUETYI, Lai; Zhiqin, Shi. How China Views the EU in Global Energy Governance: A Norm Exporter, a Partner or an Outsider? Comparative European Politics. 15 (2017) No. 1: 80.

1818 TALUS, Kim; Wüstenberg, Moritz. Risks of Expanding the Geographical Scope of EU Energy Law. European Energy and Enviromental Law Review. 26 (2017) No. 5: 138.

1819 TÜRK, Henning. Kooperation in der Krise? Die Ölkrise von 1973/74 und die Multilaterale Zusammenarbeit der Westlichen Industrieländer in der Energiepolitik. Journal of European Integration History. 22 (2016) No. 1: 47.

16 Research - Science and technology

1820 CARRAPICO, Helena; Barrinha, André. The EU as a Coherent (Cyber)Security Actor? Journal of Common Market Studies. 55 (2017) No. 6: 1254.

1821 DEGOLI, Maria-Christina. Free Movement of Workers and the RESAVER Scheme for Researchers. European Journal of Social Security. 19 (2017) No. 2: 172.

1822 FIOTT, Daniel. Patriotism, Preferences and Serendipity: Understanding the Adoption of the Defence Transfers Directive. Journal of Common Market Studies. 55 (2017) No. 5: 1045.

1823 ULNICANE, Inga. Research and Innovation as Sources of Renewed Growth? EU Policy Responses to the Crisis. Journal of European Integration. 38 (2016) No. 3: 327.

17 Education - Training - Culture

(Higher education / Lifelong learning / Qualifications / Youth programmes / Culture / Language / Books, reading and libraries / Audiovisual policy / Sport)

1824 ARMSTRONG, Kenneth A. Brexit and the Future of European Legal Studies [Editorial]. Cambridge Yearbook of European Legal Studies. 18 (2016): 1.

1825 CALligaro, Oriane; Patel, Kiran Klaus. From Competition to Cooperation in Promoting European Culture: The Council of Europe and the European Union since 1950. Journal of European Integration History. 23 (2017) No. 1: 131.

1826 CANNAS, Francesco. Reduced Rates and the Digital Economy: The Treatment of (E-)Books Highlights Some Possible Inconsistencies of the EU VAT System. EC Tax Review. 26 (2017) No. 2: 96.

1827 CARMEL, Emma. Re-interpreting Knowledge, Expertise and EU Governance: The Cases of Social Policy and Security Research Policy. Comparative European Politics. 15 (2017) No. 5: 771.

1828 CASSESE, Sabino. Legal Education Under Fire. European Review of Private Law. 25 (2017) No. 1: 143. 
1829 DIMITROVA, Antoaneta L.; Steunenberg, Bernard. The Power of Implementers: A Three-Level Game Model of Compliance with EU Policy and its Application to Cultural Heritage. Journal of European Public Policy. 24 (2017) No. 8: 1211.

1830 DYEVRE, Arthur. Fixing European Law Schools. European Review of Private Law. 25 (2017) No. 1: 151.

1831 FABELLA, Vigile Marie. Political-Economic Determinants of Education Reform: Evidence on Interest Groups and Student Outcomes. European Journal of Political Economy. (2017) No. 48: 144.

1832 GARCÍA, Borja; Meier, Henk Erik. Global Sport Power Europe? The Efficacy of the European Union in Global Sport Regulation. Journal of Common Market Studies. 55 (2017) No. 4: 850.

1833 GEERAERT, Arnout; Drieskens, Edith. Normative Market Europe: The EU as a Force for Good in International Sports Governance? Journal of European Integration. 39 (2017) No. 1: 79.

1834 GUETTO, Raffaele; Vergolini, Loris. Educational Expansion without Equalization: A Reappraisal of the 'Effectively Maintained Inequality' Hypothesis in Children's Choice of the Upper Secondary Track. European Societies. 19 (2017) No. 1: 1.

1835 HARRISON, John; Turok, Ivan. Universities, Knowledge and Regional Development. Regional Studies. 51 (2017) No. 7: 977.

1836 JANSSEN, André. Das Digitale Erbe eines Menschen. European Review of Private Law. 25 (2017) No. 4: 697.

1837 JENSEN, Carsten. Money Over Misery: Restrictive Gambling Legislation in an Era of Liberalization. Journal of European Public Policy. 24 (2017) No. 1: 119.

1838 JOERGES, Christian; Kreuder-Sonnen, Christian. European Studies and the European Crisis: Legal and Political Science between Critique and Complacency. European Law Journal. 23 (2017) No. 1-2: 118.

1839 KAISER, Wolfram. Limits of Cultural Engineering: Actors and Narratives in the European Parliament's House of European History Project. Journal of Common Market Studies. 55 (2017) No. 3: 518.

1840 KATSIREA, Irini. Newspaper Websites as Audiovisual Media Services: The New Media Online GmbH Preliminary Ruling. European Law Review. 42 (2017) No. 1: 92.

1841 LINKLATER-SAHM, Emma. The Libraries Strike Back: The 'Right to E-Lend' Under the Rental and Lending Rights Directive: Vereniging Openbare Bibliotheken. Common Market Law Review. 54 (2017) No. 5: 1555.

1842 MCCANN, Adam P. Brexit, Higher Education, and Responsible Governance [Editorial]. European Journal of Comparative Law and Governance. 4 (2017) No. 3: $205 \mathrm{pp}$.

1843 PSYCHOGIOPOULOU, Evangelia. The Cultural Open Method of Coordination: A New Boost for Cultural Policies in Europe. Maastricht Journal of European and Comparative Law. 24 (2017) No. 2: 264.

1844 SCHINDLER, Steffen. School Tracking, Educational Mobility and Inequality in German Secondary Education: Developments across Cohorts. European Societies. 19 (2017) No. 1: 28. 
18 External Relations_

(International organisations and groupings / Human rights / External service External assistance / Common Foreign and Security Policy / Security and defence / NATO / OSCE / Terrorism: international dimension / External trade / WTO / Eastern and Central Europe / Wider Europe - Neighbourhood policy / Northern dimension / Balkan region / Enlargement)

1845 ABRAHAM, Kavi Joseph; Abramson, Yehonata. A Pragmatist Vocation for International Relations: The (Global) Public and its Problems. European Journal of International Relations. 23 (2017) No. 1: 26.

1846 AGGESTAM, Lisbeth; Johansson, Markus. The Leadership Paradox in EU Foreign Policy. Journal of Common Market Studies. 55 (2017) No. 6: 1203.

1847 AKSENOVA, Marina. Of Victims and Villains in the Fight against International Terrorism. European Journal of Legal Studies. 10 (2017) No. 1: 17 pp.

1848 AUSTIN, Jonathan Luke. We Have Never Been Civilized: Torture and the Materiality of World Political Binaries. European Journal of International Relations. 23 (2017) No. 1: 49.

1849 AYTUĞ, Hüseyin [et al.]. Twenty Years of the EU-Turkey Customs Union: A Synthetic Control Method Analysis. Journal of Common Market Studies. 55 (2017) No. 3: 419.

1850 BAETENS, Freya. The European Union's Proposed Investment Court System: Addressing Criticisms of Investor-State Arbitration While Raising New Challenges Investor Protection and Enforcement. Legal Issues of Economic Integration. 43 (2016) No. 4: 367.

1851 BAK, Daehee; Kenwick, Michael R.; Palmer, Glenn. Who's Careful: Regime Type and Target Selection. European Journal of International Relations. 22 (2016) No. 4: 872.

1852 BAKER, Catherine. The 'Gay Olympics'? The Eurovision Song Contest and the Politics of LGBT/European Belonging. European Journal of International Relations. 23 (2017) No. 1: 97.

1853 BASEDOW, Robert. The European Union's New International Investment Policy: Product of Commission Entrepreneurship or Business Lobbying? European Foreign Affairs Review. 21 (2016) No. 4: 469.

1854 BECK, Martin. How to (Not) Walk the Talk: The Demand for Palestinian SelfDetermination as a Challenge for the European Neighbourhood Policy. European Foreign Affairs Review. 22 (2017) No. 1: 59.

1855 BERNHARD GAREIS, Sven; Liegl, Markus B. Europe in Asia: Policy Options of an Interested Bystander. European Foreign Affairs Review. 21 (2016) No. 3/1: 99.

1856 BERNHARD GAREIS, Sven; Wolf, Reinhard. Home Alone? The Us Pivot to Asia and Its Implications for the EU's Common Security and Defence Policy. European Foreign Affairs Review. 21 (2016) No. 3/1: 133.

1857 BIBA, Sebastian. Global Governance in the Era of Growing US-China Rivalry: What Options Exist for Europe? European Foreign Affairs Review. 21 (2016) No. 3/1: 47 .

1858 BLAKELEY, Ruth; Raphael, Sam. British Torture in the 'War on Terror'. European Journal of International Relations. 23 (2017) No. 2: 243.

1859 BLOUIN, Max; Pallage, Stéphane. Warlords, Famine and Food Aid: Who Fights, Who Starves? European Journal of Political Economy. (2016) No. 45: 18.

1860 BODENSTEIN, Thilo; Faust, Jörg. Who Cares? European Public Opinion on Foreign Aid and Political Conditionality. Journal of Common Market Studies. 55 (2017) No. 5: 955 . 
1861 BOISSON DE CHAZOURNES, Laurence. Plurality in the Fabric of International Courts and Tribunals: The Threads of a Managerial Approach. European Journal of International Law. 28 (2017) No. 1: 13.

1862 BORLINI, Leonardo; Dordi, Claudio. Deepening International Systems of Subsidy Control: The (Different) Legal Regimes of Subsidies in the EU Bilateral Preferential Trade Agreements. Columbia Journal of European Law. 23 (2017) No. 3: 551.

1863 BÖRZEL, Tanja A.; Dimitrova, Antoaneta; Schimmelfennig, Frank. European Union Enlargement and Integration Capacity: Concepts, Findings, and Policy Implications. Journal of European Public Policy. 24 (2017) No. 2: 157.

1864 BÖRZEL, Tanja A.; Schimmelfennig, Frank. Coming Together or Drifting Apart? The EU's Political Integration Capacity in Eastern Europe. Journal of European Public Policy. 24 (2017) No. 2: 178.

1865 BÖRZEL, Tanja A.; Sedelmeier, Ulrich. Larger and More Law Abiding? The Impact of Enlargement on Compliance in the European Union. Journal of European Public Policy. 24 (2017) No. 2: 197.

1866 BOSSUYT, Fabienne. Between National and European Foreign Policy: The Role of Latvia and Romania in the EU's Policy towards Central Asia. Southeast European and Black Sea Studies. 17 (2017) No. 3: 441.

1867 BOURGEOIS, Jacques H.J. Is Transatlantic Trade and Investment Partnership a Regional Contribution to Global Economic Governance TTIP's Regional Contribution to Global Economic Governance. Legal Issues of Economic Integration. 43 (2016) No. 4: 407.

1868 BRANDENBURG, Natalie C. EU Mediation as an Assemblage of Practices: Introducing a New Approach to the Study of EU Conflict Resolution. Journal of Common Market Studies. 55 (2017) No. 5: 993.

1869 BRIAN HAGER, Sandy. A Global Bond: Explaining the Safe-Haven Status of US Treasury Securities. European Journal of International Relations. 23 (2017) No. 3: 557.

1870 BRUSZT, László; Langbein, Julia. Varieties of Dis-Embedded Liberalism. EU Integration Strategies in the Eastern Peripheries of Europe. Journal of European Public Policy. 24 (2017) No. 2: 297.

1871 BRUSZT, Laszlo; Vukov, Visnja. Making States for the Single Market: European Integration and the Reshaping of Economic States in the Southern and Eastern Peripheries of Europe. West European Politics. 40 (2017) No. 4: 663.

1872 BUCHER, Bernd; Jasper, Ursula. Revisiting 'Identity' in International Relations: From Identity as Substance to Identifications in Action. European Journal of International Relations. 23 (2017) No. 2: 391.

1873 BULMER, Simon; Joseph, Jonathan. European Integration in Crisis? Of Supranational Integration, Hegemonic Projects and Domestic Politics. European Journal of International Relations. 22 (2016) No. 4: 725.

1874 BURLYUK, Olga. The 'Oops!' of EU Engagement Abroad: Analyzing Unintended Consequences of EU External Action. Journal of Common Market Studies. 55 (2017) No. 5: 1009.

1875 BÜTHE, Tim; Cho, Moohyung. Power and Institutionalized International Regulatory Cooperation: A Multi-Method Analysis of Antitrust Agreements. European Foreign Affairs Review. 22 (2017) No. 2/1: 115.

1876 CALCARA, Antonio. The Role of Experts in the European Defence Agency: An Emerging Transgovernmental Network. European Foreign Affairs Review. 22 (2017) No. 3: 377. 
1877 CANNIZZARO, Enzo. Proportionality and Margin of Appreciation in the Whaling Case: Reconciling Antithetical Doctrines? European Journal of International Law. 27 (2016) No. 4: 1061.

1878 CANNIZZARO, Enzo. Whaling into a Spider Web? The Multiple International Restraints to States' Sovereignty. European Journal of International Law. 27 (2016) No. 4: 1025.

1879 CAPONE, Francesca; de Guttry, Andrea. An Analysis of the Diplomatic Crisis between Turkey and the Netherlands in Light of the Existing International Legal Framework Governing Diplomatic and Consular Relations. European Journal of Legal Studies. 10 (2017) No. 1: 61 pp.

1880 CARDWELL, Paul James. Values in the European Union's Foreign Policy: An Analysis and Assessment of CFSP Declarations. European Foreign Affairs Review. 21 (2016) No. 4: 601.

1881 CHABAN, Natalia; Miskimmon, Alister; O'Loughlin, Ben. The EU's Peace and Security Narrative: Views from EU Strategic Partners in Asia. Journal of Common Market Studies. 55 (2017) No. 6: 1273.

1882 CHEHTMAN, Alejandro. The ad bellum Challenge of Drones: Recalibrating Permissible Use of Force. European Journal of International Law. 28 (2017) No. 1: 173.

1883 CHESTERMAN, Simon. Asia's Ambivalence about International Law and Institutions: Past, Present and Futures. European Journal of International Law. 27 (2016) No. 4: 945.

1884 CHETAIL, Vincent. Sovereignty and Migration in the Doctrine of the Law of Nations: An Intellectual History of Hospitality from Vitoria to Vattel. European Journal of International Law. 27 (2016) No. 4: 901.

1885 CHRISTIANSEN, Thomas; Tsui, Shelly. The Value and the Limitations of Comprehensive Multilateralism: An EU Perspective on the Asia-Europe Meeting. European Foreign Affairs Review. 22 (2017) No. 2: 233.

1886 CHRISTOU, George; Kyris, George. The Impact of the Eurozone Crisis on National Foreign Policy: Enhancing Europeanization in the Case of Cyprus. Journal of Common Market Studies. 55 (2017) No. 6: 1290.

1887 CHRYSSOGELOS, Angelos-Stylianos. Transnational European Party Federations as EU Foreign Policy Actors: The Activities of Europarties in Eastern Partnership States. Journal of Common Market Studies. 55 (2017) No. 2: 257.

1888 CIANCIARA, Agnieszka K. Stability, Security, Democracy: Explaining Shifts in the Narrative of the European Neighbourhood Policy. Journal of European Integration. 39 (2017) No. 1: 49.

1889 CLADI, Lorenzo; Webber, Mark. Between Autonomy and Effectiveness: Reassessing the European Union's Foreign Policy Towards the Israeli-Palestinian Conflict. European Foreign Affairs Review. 21 (2016) No. 4: 559.

1890 CLIFTON, Michael-James. EEA: Another Side to Europe. European Law Reporter. (2016) No. 5: 174 .

1891 CONSIDINE, Laura. The 'Standardization of Catastrophe': Nuclear Disarmament, the Humanitarian Initiative and the Politics of the Unthinkable. European Journal of International Relations. 23 (2017) No. 3: 681.

1892 CROSS, Mai'a K. Davis; Karolewski, Ireneusz Pawel. What Type of Power has the EU Exercised in the Ukraine-Russia Crisis? A Framework of Analysis. Journal of Common Market Studies. 55 (2017) No. 1: 3.

1893 CUNLIFFE, Philip. The Doctrine of the 'Responsibility to Protect' as a Practice of Political Exceptionalism. European Journal of International Relations. 23 (2017) No. 2: 466 . 
1894 DANISI, Carmelo. Promoting Human Rights Through the EU External Action: An Empty 'Vessel' for Sexual Minorities? European Foreign Affairs Review. 22 (2017) No. 3: 341 .

1895 D'ASPREMONT, Jean. The International Court of Justice, the Whales, and the Blurring of the Lines between Sources and Interpretation. European Journal of International Law. 27 (2016) No. 4: 1027.

1896 DAUGBJERG, Carsten. Responding to Non-Linear Internationalisation of Public Policy: The World Trade Organization and Reform of the CAP 1992-2013. Journal of Common Market Studies. 55 (2017) No. 3: 486.

1897 DAVIDSON, Natalie R. Shifting the Lens on Alien Tort Statute Litigation: Narrating US Hegemony in Filártiga and Marcos. European Journal of International Law. 28 (2017) No. 1: 147.

1898 DAVIS CROSS, Mai'a K. Counter-Terrorism in the EU's External Relations. Journal of European Integration. 39 (2017) No. 5: 609.

1899 DE BIĖVRE, Dirk; Poletti, Arlo. Why the Transatlantic Trade and Investment Partnership is Not (so) New, and Why it is Also Not (so) Bad. Journal of European Public Policy. 24 (2017) No. 10: 1506.

1900 DE GOEDE, Marieke; Wesseling, Mara. Secrecy and Security in Transatlantic Terrorism Finance Tracking. Journal of European Integration. 39 (2017) No. 3: 253.

1901 DE VILLE, Ferdi; Siles-Brügge, Gabriel. Why TTIP is a Game-Changer and its Critics Have a Point. Journal of European Public Policy. 24 (2017) No. 10: 1491.

1902 DE WILDE, Pieter; Junk, Wiebke Marie; Palmtag, Tabea. Accountability and Opposition to Globalization in International Assemblies. European Journal of International Relations. 22 (2016) No. 4: 823.

1903 DELla SALA, Vincent. Homeland Security: Territorial Myths and Ontological Security in the European Union. Journal of European Integration. 39 (2017) No. 5: 545.

1904 DELREUX, Tom; Keukeleire, Stephan. Informal Division of Labour in EU Foreign Policy-Making. Journal of European Public Policy. 24 (2017) No. 10: 1471.

1905 DEPAIGNE, Vincent. Protecting Fundamental Rights in Trade Agreements between the EU and Third Countries. European Law Review. 42 (2017) No. 4: 562.

1906 DESTRADI, Sandra. Reluctance in International Politics: A Conceptualization. European Journal of International Relations. 23 (2017) No. 2: 315.

1907 DIMITROVA, Antoaneta; Kortenska, Elitsa. What Do Citizens Want? And Why Does it Matter? Discourses among Citizens as Opportunities and Constraints for EU Enlargement. Journal of European Public Policy. 24 (2017) No. 2: 259.

1908 DOWNES, Chris. The Legality of 'Sleepwalking' in Negotiations? The Missing Coherence in EU Trade Talks with Ukraine. European Law Review. 42 (2017) No. 1: 27.

1909 DRIESKENS, Edith. Golden or Gilded Jubilee? A Research Agenda for Actorness. Journal of European Public Policy. 24 (2017) No. 10: 1534.

1910 DUNFORD, Robert. Peasant Activism and the Rise of Food Sovereignty: Decolonising and Democratising Norm Diffusion? European Journal of International Relations. 23 (2017) No. 1: 145.

1911 ELIASSON, Leif Johan; García-Duran, Patricia. Why TTIP is an Unprecedented Geopolitical Game-Changer, but Not a Polanyian Moment. Journal of European Public Policy. 24 (2017) No. 10: 1522.

1912 ENGBRINK, Dennis S. The European Union's External Action: Coherence in European Union Foreign Policy Despite Separate Legal Orders. Legal Issues of Economic Integration. 44 (2017) No. 1: 5. 
1913 EVENETT, Simon J. Resilient Soft Law? Lessons from the US-EU TTIP Negotiation on Financial Services Regulation. European Foreign Affairs Review. 22 (2017) No. 2/1:37.

1914 FAGAN, Madeleine. Security in the Anthropocene: Environment, Ecology, Escape. European Journal of International Relations. 23 (2017) No. 2: 292.

1915 FAHEY, Elaine. On the Benefits of the Transatlantic Trade and Investment Partnership (TTIP) Negotiations for the EU Legal Order: A Legal Perspective Situating TTIP in the External Relation of the EU. Legal Issues of Economic Integration. 43 (2016) No. 4: 327.

1916 FAKHOURY, Tamirace. The European Union's Engagement in Conflict Processes and Conflict Spillovers: The Case of Lebanon Since the Onset of the Syrian War. European Foreign Affairs Review. 22 (2017) No. 1: 39.

1917 FEKLYUNINA, Valentina. Soft Power and Identity: Russia, Ukraine and the 'Russian World(s)'. European Journal of International Relations. 22 (2016) No. 4: 773.

1918 FERNÁNDEZ-PONS, Xavier; Polanco, Rodrigo; Torrent, Ramon. CETA on Investment:the Definitive Surrender of EU Law to Gats and NAFTA/BITS. Common Market Law Review. 54 (2017) No. 5: 1319.

1919 FERRER-I-CARBONELL, Ada; Gërxhani, Klarita. Tax Evasion and Well-Being: A Study of the Social and Institutional Context in Central and Eastern Europe. European Journal of Political Economy. (2016) No. 45 Supplement: 149.

1920 FREEDMAN, Joshua. Status Insecurity and Temporality in World Politics. European Journal of International Relations. 22 (2016) No. 4: 797.

1921 GEHRING, Thomas; Urbanski, Kevin; Oberthür, Sebastian. The European Union as an Inadvertent Great Power: EU Actorness and the Ukraine Crisis. Journal of Common Market Studies. 55 (2017) No. 4: 727.

1922 GIUMELLI, Francesco. The Redistributive Impact of Restrictive Measures on EU Members: Winners and Losers from Imposing Sanctions on Russia. Journal of Common Market Studies. 55 (2017) No. 5: 1062.

1923 GKLIATI, Mariana. The Application of the EU-Turkey Agreement: A Critical Analysis of the Decisions of the Greek Appeals Committees. European Journal of Legal Studies. 10 (2017) No. 1: 81 pp.

1924 GRAHAM, Erin R. The Institutional Design of Funding Rules at International Organizations: Explaining the Transformation in Financing the United Nations. European Journal of International Relations. 23 (2017) No. 2: 365.

1925 GRAVELLE, Timothy B.; Reifler, Jason; Scotto, Thomas J. The Structure of Foreign Policy Attitudes in Transatlantic Perspective: Comparing the United States, United Kingdom, France and Germany. European Journal of Political Research. 56 (2017) No. 4: 757.

1926 GREGORY, Thomas. Dismembering the Dead: Violence, Vulnerability and the Body in War. European Journal of International Relations. 22 (2016) No. 4: 944.

1927 GRISEL, Florian. Treaty-Making between Public Authority and Private Interests: The Genealogy of the Convention on the Recognition and Enforcement of Foreign Arbitral Awards. European Journal of International Law. 28 (2017) No. 1: 73.

1928 GRUNI, Giovanni. Law or Aspiration? The European Union Proposal for a Labour Standards Clause in the Transatlantic Trade and Investment Partnership Sustainable Development. Legal Issues of Economic Integration. 43 (2016) No. 4: 399.

1929 GRZYBOWSKI, Janis. To Be or Not to Be: The Ontological Predicament of State Creation in International Law. European Journal of International Law. 28 (2017) No. 2: 409. 
1930 HADJIGEORGIOU, Nasia. Remedying Displacement in Frozen Conflicts: Lessons From the Case of Cyprus. Cambridge Yearbook of European Legal Studies. 18 (2016): 152 .

1931 HALEH DAVIS, Muriam. The Sahara as the 'Cornerstone' of Eurafrica: European Integration and Technical Sovereignty Seen from the Desert. Journal of European Integration History. 23 (2017) No. 1: 97.

1932 HANSEN, Lene. Reading Comics for the Field of International Relations: Theory, Method and the Bosnian War. European Journal of International Relations. 23 (2017) No. 3: 581.

1933 HARPAZ, Guy. The Causes of the EU's Ineffectual Contribution to Resolution of the Abkhazian and South Ossetian Conflicts. European Foreign Affairs Review. 22 (2017) No. 2: 253

1934 HARZL, Benedikt C. Beyond Enlargement: Legal and (Geo-)political Landmarks of the EU's Eastern Challenge. Review of Central and East European Law. 42 (2017) No. 4: 409.

1935 HELDT, Eugénia. Shaping Global Trade Governance Rules: New Powers' Hard and Soft Strategies of Influence at the WTO. European Foreign Affairs Review. 22 (2017) No. 2/1: 19.

1936 HERBEL, Annika. Parliamentary Scrutiny of the EU's Common Foreign and Security Policy. West European Politics. 40 (2017) No. 1: 161.

1937 HERON, Tony; Murray-Evans, Peg. Limits to Market Power: Strategic Discourse and Institutional Path Dependence in the European Union-African, Caribbean and Pacific Economic Partnership Agreements. European Journal of International Relations. 23 (2017) No. 2: 341.

1938 HIJMANS, Kielke. The Transatlantic Trade and Investment Partnership and the Developments in the Area of Privacy and Data Protection Data Protection. Legal Issues of Economic Integration. 43 (2016) No. 4: 385.

1939 HOEKMAN, Bernard. The World Trade Order: Global Governance by Judiciary? European Journal of International Law. 27 (2016) No. 4: 1083.

1940 HOEKMAN, Bernard; Mavroidis, Petros C. MFN Clubs and Scheduling Additional Commitments in the GATT: Learning from the GATS. European Journal of International Law. 28 (2017) No. 2: 387.

1941 HOWORTH, Jolyon. 'Stability on the Borders': The Ukraine Crisis and the EU's Constrained Policy Towards the Eastern Neighbourhood. Journal of Common Market Studies. 55 (2017) No. 1: 121.

1942 HOWSE, Robert. The WTO 20 Years On: A Reply to the Responses. European Journal of International Law. 27 (2016) No. 4: 1127.

1943 HUBER, Daniela. Youth as a New 'Foreign Policy Challenge' in Middle East and North Africa: A Critical Interrogation of European Union and US Youth Policies in Morocco and Tunisia. European Foreign Affairs Review. 22 (2017) No. 1: 111.

1944 HYAMS, Adam; Puig, Gonzalo Villalta. Preferential Trade Agreements and the World Trade Organization: Developments to the Dispute Settlement Understanding. Legal Issues of Economic Integration. 44 (2017) No. 3: 237.

1945 ISANI, Mujtaba; Schlipphak, Bernd. The Desire for Sovereignty - An Explanation of EU Attitudes in the Arab World. Journal of Common Market Studies. 55 (2017) No. 3: 502 .

1946 IZADNIA, Rodd. European Union - Anti-Dumping Measures on Biodiesel from Argentina (EU-Biodiese1), DS473. World Trade Review. 16 (2017) No. 3: 545.

1947 JANČIĆ, Davor. TTIP and Legislative-Executive Relations in EU Trade Policy. West European Politics. 40 (2017) No. 1: 202. 
1948 JOHNSON, Jamie M. Beyond a Politics of Recrimination: Scandal, Ethics and the Rehabilitation of Violence. European Journal of International Relations. 23 (2017) No. 3: 703 .

1949 JOHNSON, McKenzie F. Institutional Change in a Conflict Setting: Afghanistan's Environment Law. European Journal of International Relations. 23 (2017) No. 1: 168.

1950 KAROLEWSKI, Ireneusz Pawel; Cross, Mai'a K. Davis. The EU's Power in the RussiaUkraine Crisis: Enabled or Constrained? Journal of Common Market Studies. 55 (2017) No. 1: 137.

1951 KEIJZER, Niels. Expectation Management? Contrasting the EU's 2030 Agenda Discourse with Its Performance in Evaluating Policy Coherence for Development. European Foreign Affairs Review. 22 (2017) No. 2: 177.

1952 KELLY, Serena; Chaban, Natalia; Elgström, Ole. Perceptions of the European Union's Fledgling Delegations: More Coherence, More Effectiveness? European Foreign Affairs Review. 21 (2016) No. 4: 493.

1953 KETELAARS, Elise. What Place for Gender Mainstreaming in the EU's Framework on Support to Transitional Justice? European Foreign Affairs Review. 22 (2017) No. 3: 323 .

1954 KEULEERS, Floor. Stories of Moral Actorship: European Union and Chinese Narratives Towards Africa. European Foreign Affairs Review. 21 (2016) No. 4: 517.

1955 KLEINLEIN, Thomas. Jus Cogens Re-examined: Value Formalism in International Law. European Journal of International Law. 28 (2017) No. 1: 295.

1956 KLOFAT, Aleksandra. Regulatory Competition within the Eurasian Economic Union and the European Union: A Comparative Legal Analysis. Legal Issues of Economic Integration. 44 (2017) No. 2: 173.

1957 KOBZA, Piotr. Accession of Iceland to the European Union: A Failure Beyond Repair? European Foreign Affairs Review. 22 (2017) No. 2: 129.

$1958 \mathrm{KOCH}$ MIKALSEN, Kjartan. Equal Sovereignty: On the Conditions of Global Political Justice. Arena Working Papers. (2017) No. 9: 27 pp.

1959 KOENIG, Nicole. Libya and Syria: Inserting the European Neighbourhood Policy in the European Union's Crisis Response Cycle. European Foreign Affairs Review. 22 (2017) No. 1: 19.

1960 KORHONEN, Outi. Within and Beyond Interdisciplinarity in International Law and Human Rights. European Journal of International Law. 28 (2017) No. 2: 625.

1961 KRÄMER-HOPPE, Rike U.; Krüger, Tilman. International Adjudication as a Mode of EU External Governance? The WTO Seal Case. Journal of Common Market Studies. 55 (2017) No. 3: 535.

1962 KRIZIC, Ivo. For the Sake of Market Access: Comparing EU and US Approaches to Liberalize Public Procurement in Brazil, India and China. European Foreign Affairs Review. 22 (2017) No. 2/1: 77.

1963 KRIZIC, Ivo; Serrano, Omar. Exporting Intellectual Property Rights to Emerging Countries: EU and US Approaches Compared. European Foreign Affairs Review. 22 (2017) No. 2/1: 57.

1964 KUDRIASHOVA, Olga. Religious Associations as a National Security Threat: The Russian View in Light of European Standards. Review of Central and East European Law. 42 (2017) No. 2-3: 101.

1965 KÜHN, Baca; Werner, Miguel. The Eurasian Economic Union. (I), Risks and Oppurtunities of an Emerging Bipolar Europe. European Law Reporter. (2016) No. 6: 229. 
1966 KUNZ, Rahel; Maisenbacher, Julia. Women in the Neighbourhood: Reinstating the European Union's Civilising Mission on the Back of Gender Equality Promotion? European Journal of International Relations. 23 (2017) No. 1: 122.

1967 KUZIO, Taras. Ukraine Between a Constrained EU and Assertive Russia. Journal of Common Market Studies. 55 (2017) No. 1: 103.

1968 LACEY, Joseph; Bauböck, Rainer. Enlargement, Association, Accession - a Normative Account of Membership in a Union of States. Journal of European Integration. 39 (2017) No. 5: 529.

1969 LAMP, Nicolas. The 'Development' Discourse in Multilateral Trade Lawmaking. World Trade Review. 16 (2017) No. 3: 475.

1970 LANG, Andrew. The Judicial Sensibility of the WTO Appellate Body. European Journal of International Law. 27 (2016) No. 4: 1095.

1971 LANGE, Felix. Between Systematization and Expertise for Foreign Policy: The Practice-Oriented Approach in Germany's International Legal Scholarship (1920-1980). European Journal of International Law. 28 (2017) No. 2: 535.

1972 LANOVOY, Vladyslav. The Use of Force by Non-State Actors and the Limits of Attribution of Conduct. European Journal of International Law. 28 (2017) No. 2: 563.

1973 LARIK, Joris. Critiquing the Transatlantic Trade and Investment Partnership (TTIP): Systemic Consequences for Global Governance and the Rule of Law TTIP's Regional Contribution to Global Economic Governance. Legal Issues of Economic Integration. 43 (2016) No. 4: 423.

1974 LAVENEX, Sandra; Jurje, Flavia. EU/US Migration Policy Towards Emerging Countries: Regulatory Power Reversed? European Foreign Affairs Review. 22 (2017) No. 2/1: 157.

1975 LAVENEX, Sandra; Krizic, Ivo; Serrano, Omar. EU and US Regulatory Power Under Strain? Emerging Countries and the Limits of External Governance. European Foreign Affairs Review. 22 (2017) No. 2/1: 1.

1976 LEMNITZER, Jan Martin. International Commissions of Inquiry and the North Sea Incident: A Model for a MH17 Tribunal? European Journal of International Law. 27 (2016) No. 4: 923.

1977 LENZ, Tobias; Burilkov, Alexandr. Institutional Pioneers in World Politics: Regional Institution Building and the Influence of the European Union. European Journal of International Relations. 23 (2017) No. 3: 654.

1978 LEVY, Yagil. Control from Within: How Soldiers Control the Military. European Journal of International Relations. 23 (2017) No. 1: 192.

1979 LIGHTFOOT, Simon; Kim, Soyeun. The EU and the Negotiation of Global Development Norms: The Case of Aid Effectiveness. European Foreign Affairs Review. 22 (2017) No. 2: 159.

1980 LITTLE, Adrian; Vaughan-Williams, Nick. Stopping Boats, Saving Lives, Securing Subjects: Humanitarian Borders in Europe and Australia. European Journal of International Relations. 23 (2017) No. 3: 533.

1981 LOKE, Beverly. Unpacking the Politics of Great Power Responsibility: Nationalist and Maoist China in International Order-Building. European Journal of International Relations. 22 (2016) No. 4: 847.

1982 MAAS, Willem. Boundaries of Political Community in Europe, the US, and Canada. Journal of European Integration. 39 (2017) No. 5: 575.

1983 MAISLEY, Nahuel. The International Right of Rights? Article 25(a) of the ICCPR as a Human Right to Take Part in International Law-Making. European Journal of International Law. 28 (2017) No. 1: 89. 
1984 MANTILLA, Giovanni. Conforming Instrumentalists: Why the USA and the United Kingdom Joined the 1949 Geneva Conventions. European Journal of International Law. 28 (2017) No. 2: 483.

1985 MASTROMATTEO, Andrea. WTO and SOEs: Article XVII and Related Provisions of the GATT 1994. World Trade Review. 16 (2017) No. 4: 601.

1986 MATTHEIS, Frank; Wunderlich, Uwe. Regional actorness and interregional relations: ASEAN, the EU and Mercosur. Journal of European Integration. 39 (2017) No. 6: 723 .

1987 MAULL, Hanns W. European Policies Towards China and the United States: Can They Support a Strategic Triad? European Foreign Affairs Review. 21 (2016) No. 3/1: 29 .

1988 MAVELLI, Luca. Governing the Resilience of Neoliberalism through Biopolitics. European Journal of International Relations. 23 (2017) No. 3: 489.

1989 MAVROIDIS, Petros C. The Gang That Couldn't Shoot Straight: The Not So Magnificent Seven of the WTO Appellate Body. European Journal of International Law. 27 (2016) No. 4: 1107.

1990 MAVROIDIS, Petros C.; Janow, Merit E. Free Markets, State Involvement, and the WTO: Chinese State-Owned Enterprises in the Ring. World Trade Review. 16 (2017) No. 4: 571 .

1991 MCCARTHY, Daniel R.; Fluck, Matthew. The Concept of Transparency in International Relations: Towards a Critical Approach. European Journal of International Relations. 23 (2017) No. 2: 416.

1992 MCKENZIE, Lachlan; Meissner, Katharina L. Human Rights Conditionality in European Union Trade Negotiations: The Case of the EU-Singapore FTA. Journal of Common Market Studies. 55 (2017) No. 4: 832.

1993 MELISSEN, Jan; Zweers, Wouter. High Stakes of the Small EU Partnership Instrument on the Eve of the 2017 Mid-Term Review. European Foreign Affairs Review. 22 (2017) No. 2: 147.

1994 MEUNIER, Sophie. Integration by Stealth: How the European Union Gained Competence over Foreign Direct Investment. Journal of Common Market Studies. 55 (2017) No. 3: 593.

1995 MICHALSKI, Anna; Norman, Ludvig. Conceptualizing European Security Cooperation: Competing International Political Orders and Domestic Factors. European Journal of International Relations. 22 (2016) No. 4: 749.

1996 MICHALSKI, Anna; Pan, Zhongqi. Role Dynamics in a Structured Relationship: The EU-China Strategic Partnership. Journal of Common Market Studies. 55 (2017) No. 3: 611 .

1997 MITCHELL, Audra. Is IR Going Extinct? European Journal of International Relations. 23 (2017) No. 1: 3.

1998 MORINA, Visar. Prospective Constitutional Changes in Kosovo Emanating from the EU Pre-Accession Process. Croatian Yearbook of European Law and Policy. 12 (2016): 299.

1999 MORRIS, Narrelle; Knaap, Aden. When Institutional Design Is Flawed: Problems of Cooperation at the United Nations War Crimes Commission, 1943-1948. European Journal of International Law. 28 (2017) No. 2: 513.

2000 MOSKALENKO, Oleksandr. 'Parliamentarisation' of the CFSP: Wishful Thinking or a Rational Choice? Croatian Yearbook of European Law and Policy. 12 (2016): 251.

2001 MULLER, Gilles. De Facto Discrimination under GATS National Treatment: Has the Genie of Trade Liberalization Been Let out of the Bottle. Legal Issues of Economic Integration. 44 (2017) No. 2: 151. 
2002 MULLER, Gilles. Troubled Relationships under the GATS: Tensions between Market Access (Article XVI), National Treatment (Article XVII), and Domestic Regulation (Article VI). World Trade Review. 16 (2017) No. 3: 449.

2003 MÜLLER, Patrick; Slominski, Peter. The Role of Law in EU Foreign Policy-making: Legal Integrity, Legal Spillover, and the EU Policy of Differentiation towards Israel. Journal of Common Market Studies. 55 (2017) No. 4: 871.

2004 NASIRITOUSI, Naghmeh; Hjerpe, Mattias; Bäckstrand, Karin. Normative Arguments for Non-State Actor Participation in International Policymaking Processes: Functionalism, Neocorporatism or Democratic Pluralism? European Journal of International Relations. 22 (2016) No. 4: 920.

2005 NATORSKI, Michal; Pomorska, Karolina. Trust and Decision-making in Times of Crisis: The EU's Response to the Events in Ukraine. Journal of Common Market Studies. 55 (2017) No. 1: 54.

2006 NEGISHI, Yota. The Pro Homine Principle's Role in Regulating the Relationship between Conventionality Control and Constitutionality Control. European Journal of International Law. 28 (2017) No. 2: 457.

2007 NEUWAHL, Nanette. CETA as a Potential Model for (Post-Brexit) UK-EU Relations. European Foreign Affairs Review. 22 (2017) No. 3: 279.

2008 NITOIU, Cristian. European and Eurasian Integration: Competition and Cooperation in the Post-Soviet Space. Journal of European Integration. 39 (2017) No. 4: 469.

2009 NOESSELT, Nele. The European Union and China's Multidimensional Diplomacy: Strategic Triangulation? European Foreign Affairs Review. 21 (2016) No. 3/1: 11.

2010 NOVÁKY, Niklas I. M. The Invocation of the European Union's Mutual Assistance Clause: A Call for Enforced Solidarity. European Foreign Affairs Review. 22 (2017) No. 3: 357 .

2011 NOVOTNÁ, Tereza. The EU as a Global Actor: United We Stand, Divided We Fall. Journal of Common Market Studies. 55 (2017) No. S1: 177.

2012 NUZZO, Silvia. Tackling Diversity Inside WTO: The GATT Moral Clause after Colombia - Textiles. European Journal of Legal Studies. 10 (2017) No. 1: 267 pp.

2013 ODDVAR ERIKSEN, Erik. Three Conceptions of Global Political Justice. Arena Working Papers. (2017) No. 1: 39 pp.

2014 OEHRI, Myriam. Labour Rights Promotion in the Absence of Conditionality? How the EU and the US Engage China and India. European Foreign Affairs Review. 22 (2017) No. 2/1: 137.

2015 ORENSTEIN, Mitchell A.; Kelemen, R. Daniel. Trojan Horses in EU Foreign Policy. Journal of Common Market Studies. 55 (2017) No. 1: 87.

2016 ORTINO, Federico. Defining Indirect Expropriation: The Transatlantic Trade and Investment Partnership and the (Elusive) Search for Greater Certainty Investor Protection and Enforcement. Legal Issues of Economic Integration. 43 (2016) No. 4: 351.

2017 PALOSAARI, Teemu. From 'Thin' to 'Thick' Foreign Policy Europeanization: Common Foreign and Security Policy and Finland. European Foreign Affairs Review. 21 (2016) No. 4: 579.

2018 PAN, Chengxin; Turner, Oliver. Neoconservatism as Discourse: Virtue, Power and US Foreign Policy. European Journal of International Relations. 23 (2017) No. 1: 74.

2019 PAUWELYN, Joost. The WTO 20 Years On: ‘Global Governance by Judiciary’ or, Rather, Member-driven Settlement of (Some) Trade Disputes between (Some) WTO Members? European Journal of International Law. 27 (2016) No. 4: 1119. 
2020 PAZ, Moria. The Law of Walls. European Journal of International Law. 28 (2017) No. 2: 601.

2021 PEPERMANS, Astrid. The Huawei Case and What It Reveals About Europe's Trade Policy. European Foreign Affairs Review. 21 (2016) No. 4: 539.

2022 PETERSEN, Niels. The International Court of Justice and the Judicial Politics of Identifying Customary International Law. European Journal of International Law. 28 (2017) No. 2: 357.

2023 PETERSMANN, Ernst-Ulrich. The European Union's 'Cosmopolitan Foreign Policy Constitution' and Its Disregard in Transatlantic Free Trade Agreements. European Foreign Affairs Review. 21 (2016) No. 4: 449.

2024 PIRIM, Ceren Zeynep. A Neverending Story: The Free Movement of Turkish Workers within the European Union. Legal Issues of Economic Integration. 44 (2017) No. 1: 49.

2025 PLAKOKEFALOS, Ilias. The Use of Force by Non-State Actors and the Limits of Attribution of Conduct: A Reply to Vladyslav Lanovoy. European Journal of International Law. 28 (2017) No. 2: 587.

2026 QUÉNIVET, Noëlle. Does and Should International Law Prohibit the Prosecution of Children for War Crimes? European Journal of International Law. 28 (2017) No. 2: 433.

2027 RAFFEINER, Stefan. Organ Practice in the Whaling Case: Consensus and Dissent between Subsequent Practice, Other Practice and a Duty to Give Due Regard. European Journal of International Law. 27 (2016) No. 4: 1043.

2028 RALPH, Jason; Gifkins, Jess. The Purpose of United Nations Security Council Practice: Contesting Competence Claims in the Normative Context Created by the Responsibility to Protect. European Journal of International Relations. 23 (2017) No. 3: 630.

2029 RAMPTON, David; Nadarajah, Suthaharan. A Long View of Liberal Peace and its Crisis. European Journal of International Relations. 23 (2017) No. 2: 441.

2030 RAUNIO, Tapio; Wagner, Wolfgang. Towards Parliamentarisation of Foreign and Security Policy? West European Politics. 40 (2017) No. 1: 1.

2031 RICHERT, Jörn. From Single Voice to Coordinated Polyphony EU Energy Policy and the External Dimension. European Foreign Affairs Review. 22 (2017) No. 2: 213.

2032 RIDDERVOLD, Marianne; Bosilca, Ruxandra-Laura. Not so Humanitarian After All? Assessing EU Naval Mission Sophia. Arena Working Papers. (2017) No. 5: 25 pp.

2033 RIDDERVOLD, Marianne; Trondal, Jarle. Integrating Nascent Organisations. On the Settlement of the European External Action Service. Journal of European Integration. 39 (2017) No. 1: 33.

2034 RITTBERGER, Berthold; Schwarzenbeck, Helena; Zangl, Bernhard. Where Does the Buck Stop? Explaining Public Responsibility Attributions in Complex International Institutions. Journal of Common Market Studies. 55 (2017) No. 4: 909.

2035 RÖSCH, Felix; Watanabe, Atsuko. Approaching the Unsynthesizable in International Politics: Giving Substance to Security Discourses through Basso Ostinato? European Journal of International Relations. 23 (2017) No. 3: 609.

2036 ROTARU, Vasile; Troncotă, Miruna. Continuity and Change in Instrumentalizing 'The Precedent'. How Russia Uses Kosovo to Legitimize the Annexation of Crimea. Southeast European and Black Sea Studies. 17 (2017) No. 3: 325.

2037 ROTUNNO, Lorenzo. Political Stability and Trade Agreements: Evidence for 'Endgame FTAs'. European Journal of Political Economy. (2016) No. 45: 133. 
2038 RUIZ FABRI, Hélène. The WTO Appellate Body or Judicial Power Unleashed: Sketches from the Procedural Side of the Story. European Journal of International Law. 27 (2016) No. 4: 1075.

2039 RUSSO, Eleonora. Towards an Exclusive Competence of the EU to Conclude Climate Agreements? European Foreign Affairs Review. 22 (2017) No. 2: 197.

2040 SANDS, Philippe. Reflections on International Judicialization. European Journal of International Law. 27 (2016) No. 4: 885.

2041 SCHILDE, Kaija. European Military Capabilities: Enablers and Constraints on EU Power? Journal of Common Market Studies. 55 (2017) No. 1: 37.

2042 SCHIMMELFENNIG, Frank; Winzen, Thomas. Eastern Enlargement and Differentiated Integration: Towards Normalization. Journal of European Public Policy. 24 (2017) No. 2: 239

2043 SEEBERG, Peter. Mobility Partnerships and Security Subcomplexes in the Mediterranean: The Strategic Role of Migration and the European Union's Foreign and Security Policies Towards the MENA Region. European Foreign Affairs Review. 22 (2017) No. 1: 91.

2044 SEEBERG, Peter; Shteiwi, Musa. Introduction: New Challenges for the European Union in the Arab Mediterranean and the Revision of the European Neighbourhood Policy. European Foreign Affairs Review. 22 (2017) No. 1: 1.

2045 SICURELLI, Daniela. The Conditions for Effectiveness of EU Human Rights Promotion in Non-Democratic States. A Case Study of Vietnam. Journal of European Integration. 39 (2017) No. 6: 739.

2046 SJURSEJ, Helene. Global Justice and Foreign Policy. Arena Working Papers. (2017) No. 6: 28 pp.

2047 SJURSEN, Helene; Rosén, Guri. Arguing Sanctions. On the EU's Response to the Crisis in Ukraine. Journal of Common Market Studies. 55 (2017) No. 1: 20.

2048 SMITH, Karen E. EU Member States at the UN: A Case of Europeanization Arrested? Journal of Common Market Studies. 55 (2017) No. 3: 628.

2049 SOLOMON, Ty; Steele, Brent J. Micro-Moves in International Relations Theory. European Journal of International Relations. 23 (2017) No. 2: 267.

2050 SQUIRE, Vicki. Governing Migration through Death in Europe and the US: Identification, Burial and the Crisis of Modern Humanism. European Journal of International Relations. 23 (2017) No. 3: 513.

2051 STANZEL, Volker. Need Disputes Turn into Armed Conflicts? East Asia's Maritime Conflicts in a New Environment: Consequences for the European Union. European Foreign Affairs Review. 21 (2016) No. 3/1: 65.

2052 STIEGLER, Valérie. Envisager le Maghreb à la Lumière du Renouveau des Relations Europe/Monde Arabe au Début des Années 1970. Journal of European Integration History. 23 (2017) No. 1: 113.

2053 STODDARD, Edward. Tough Times, Shifting Roles: Examining the EU's Commercial Diplomacy in Foreign Energy Markets. Journal of European Public Policy. 24 (2017) No. 7: 1048.

2054 TAKACS, Tamara. Situating the Transatlantic Trade and Investment Partnership (Negotiations) in European Union Common Commercial Policy Situating TTIP in the External Relation of the EU. Legal Issues of Economic Integration. 43 (2016) No. 4: 341.

2055 TATHAM, Allan F. 'Off the Bench but Not off Duty': The Judicial Diplomacy of the Court of Justice. European Foreign Affairs Review. 22 (2017) No. 3: 303. 
2056 TEZCAN/IDRIZ, Narin. Family Reunification Under the Standstill Clauses of EUTurkey Association Law: Genc. Common Market Law Review. 54 (2017) No. 1: 263.

2057 THOMAS, Daniel C. Beyond Identity: Membership Norms and Regional Organization. European Journal of International Relations. 23 (2017) No. 1: 217.

2058 TROMMER, Silke. The WTO in an Era of Preferential Trade Agreements: Thick and Thin Institutions in Global Trade Governance. World Trade Review. 16 (2017) No. 3: 501.

2059 TUSCHHOFF, Christian. Emulating Ostpolitik: A Template for Regional Conflict Resolution in East Asia. European Foreign Affairs Review. 21 (2016) No. 3/1: 117.

2060 VAN DER MEI, Anne Pieter. EU External Relations and Internal Inter-Institutional Conflicts: The Battlefield of Article 218 TFEU. Maastricht Journal of European and Comparative Law. 23 (2016) No. 6: 1051.

2061 VAN ELSUWEGE, Peter. Legal Creativity in EU External Relations: The Stabilization and Association Agreement Between the EU and Kosovo. European Foreign Affairs Review. 22 (2017) No. 3: 393.

2062 VAN ELSUWEGE, Peter. Upholding the Rule of Law in the Common Foreign and Security Policy: H v. Council. Common Market Law Review. 54 (2017) No. 3: 841.

2063 VASEV, Nikolay. Divergent Resources and Convergent Transposition Strategies - the East-West Cleavage and its Implications for Transposition. Journal of European Integration. 39 (2017) No. 3: 271.

2064 VON BAHR, Johanna. Explaining Child Rights Mainstreaming in EU External Policy. Comparative European Politics. 15 (2017) No. 4: 499.

2065 VON BOGDANY, Armin; Goldmann, Matthias; Venzke, Ingo. From Public International to International Public Law: Translating World Public Opinion into International Public Authority. European Journal of International Law. 28 (2017) No. 1: 115 .

2066 WAGENER, Martin. Power Shifts and Tensions in East Asia: Implications for European Security. European Foreign Affairs Review. 21 (2016) No. 3/1:81 .

2067 WAGNER, Wolfgang [et al.]. The Party Politics of Legislative-Executive Relations in Security and Defence Policy. West European Politics. 40 (2017) No. 1: 20.

2068 WALLACE BROWN, Garrett; Bohm, Alexandra. Introducing Jus Ante Bellum as a Cosmopolitan Approach to Humanitarian Intervention. European Journal of International Relations. 22 (2016) No. 4: 897.

2069 WANG, Lei. Tug, Hug or Both? A Comparative Analysis of EU and US Competition Policy Permeation to Brazil and China. European Foreign Affairs Review. 22 (2017) No. 2/1: 95.

2070 WINNARD, Scott. The End of the Line: C \& J Clark International Ltd and the Nakajima Exception. Legal Issues of Economic Integration. 44 (2017) No. 2: 197.

2071 WOLF, Reinhard; Liegl, Markus; Biba, Sebastian. Introduction: Perils of US-China Confrontation - Implications for Europe. European Foreign Affairs Review. 21 (2016) No. 3/1: 1.

2072 WU, Mark. China's Export Restrictions and the Limits of WTO Law. World Trade Review. 16 (2017) No. 4: 673.

2073 YANG, Yifan. How do EU Norms Diffuse? Rule of Law Promotion in EU-China Cooperation on Environmental Governance. Journal of European Integration. 39 (2017) No. 1: 63.

2074 YIN, Zhiguang. Heavenly Principles? The Translation of International Law in 19th-century China and the Constitution of Universality. European Journal of International Law. 27 (2016) No. 4: 1005. 
2075 ZACCARIA, Benedetto. Assessing Yugoslavia's Place in Western European Stabilisation Policies in Southern Europe, 1974-1976. Journal of European Integration History. 22 (2016) No. 1: 67.

2076 ZANG, Michelle Q. Shall We Talk? Judicial Communication between the CJEU and WTO Dispute Settlement. European Journal of International Law. 28 (2017) No. 1: 273 .

2077 ZARDO, Federica. Migration, Mobility and the Challenge of Co-ownership Exploring European Union-Tunisia Post-Revolutionary Agenda. European Foreign Affairs Review. 22 (2017) No. 1: 75.

2078 ZENG, Jinghan. Does Europe Matter? The Role of Europe in Chinese Narratives of 'One Belt One Road' and 'New Type of Great Power Relations'. Journal of Common Market Studies. 55 (2017) No. 5: 1162.

2079 ZHELYAZKOVA, Asya; Kaya, Cansarp; Schrama, Reini. Notified and Substantive Compliance with EU Law in Enlarged Europe: Evidence from Four Policy Areas. Journal of European Public Policy. 24 (2017) No. 2: 216.

2080 ZWOLSKI, Kamil. Wider Europe, Greater Europe? David Mitrany on European Security Order. Journal of Common Market Studies. 55 (2017) No. 3: 645.

19 Law

(Nature, effect and principles of EC law / European Court of Justice - legal issues / European Conventions / European Treaties / European Court of Human Rights / Legal systems and traditions)

2081 ALBANESI, Enrico. The Mechanisms Used to Review Existing Legislation in the Civil Law System: Case Study - Italy. European Journal of Law Reform. 18 (2016) No. 3: 275.

2082 ALBERTI, Jacopo. New Developments in the EU System of Judicial Protection: The Creation of the Unified Patent Court and Its Future Relations with the CJEU. Maastricht Journal of European and Comparative Law. 24 (2017) No. 1: 6.

2083 ALEMANNO, Alberto; Pech, Laurent. Thinking Justice Outside the Docket: A Critical Assessment of the Reform of the EU'S Court System. Common Market Law Review. 54 (2017) No. 1: 129.

2084 ALLOTT, Philip. Fundamental Legal Aspects of Withdrawal from the EU: Eight Stages on the Way to a New Relationship. European Law Reporter. (2016) No. 5: 186.

2085 ANAGNOSTARAS, Georgios. Solange III? Fundamental Rights Protection under the National Identity Review. European Law Review. 42 (2017) No. 2: 234.

2086 ANTONOV, Mikhail. Review Essay: Law and Economics, Judicial Pragmatism and Their Limits on Both Sides of the Atlantic. Review of Central and East European Law. 42 (2017) No. 1: 73.

2087 ARENA, Amedeo. Exercise of EU Competences and Pre-emption of Member States' Powers in the Internal and the External Sphere: Towards 'Grand Unification'? Yearbook of European Law. 35 (2016) No. 1: 28.

2088 BACKHAUS, Juergen G. Lawyers' Economics Versus Economic Analysis of Law: A Critique of Professor Posner's 'Economic' Approach to Law by Reference to a Case Concerning Damages for Loss of Earning Capacity. European Journal of Law and Economics. 43 (2017) No. 3: 517.

2089 BAEKKESKOV, Erik; Öberg, Perola. Freezing Deliberation through Public Expert Advice. Journal of European Public Policy. 24 (2017) No. 7: 1006. 
2090 BAR NIV, Moshe; Lachman, Ran. Judges' Perspective on the Level of Punishment. European Journal of Legal Studies. 9 (2017) No. 2: 171 pp.

2091 BARBISAN, Benedetta. The Otherness in Comparative Law. European Journal of Comparative Law and Governance. 4 (2017) No. 2: 140 pp.

2092 BARLOW, Anna. Administrative Law and Human Rights Standards in Legal Aid: An Overview with Examples from Finland and England \& Wales. European Public Law. 23 (2017) No. 1: 165.

2093 BASHESKA, Elena; Kochenov, Dimitry. The Meso Level: Means of Interaction between EU and International Law: 'Good Fences Make Good Neighbors' and Beyond ... Two Faces of the Good Neighbourliness Principle. Yearbook of European Law. 35 (2016) No. 1:

2094 BAYRAM, A. Burcu. Good Europeans? How European Identity and Costs Interact to Explain Politician Attitudes towards Compliance with European Union Law. Journal of European Public Policy. 24 (2017) No. 1: 42.

2095 BECK, Gunnar. The Macro Level: The Structural Impact of General International Law on EU Law: The Court of Justice of the EU and the Vienna Convention on the Law of Treaties. Yearbook of European Law. 35 (2016) No. 1: 484.

2096 BENESTAD ANDERSSEN, Harald. The Duty of Disclosure in the PEICL: A Scandinavian Perspective. European Review of Private Law. 25 (2017) No. 5: 967.

2097 BJORGE, Eirik. Revision of the Norwegian Constitution of 1814 and Incorporation of Human Rights Conventions. European Public Law. 23 (2017) No. 4: 699.

2098 BLAUBERGER, Michael; Kelemen, R. Daniel. Can Courts Rescue National Democracy? Judicial Safeguards Against Democratic Backsliding in the EU. Journal of European Public Policy. 24 (2017) No. 3: 321.

2099 BLOKKER, Niels. The Macro Level: The Structural Impact of General International Law on EU Law: International Legal Personality of the European Communities and the European Union: Inspirations from Public International Law. Yearbook of European Law. 35 (2016) No. 1: 471.

2100 BÖTTNER, Robert. The Treaty Amendment Procedures and the Relationship between Article 31(3) TEU and the General Bridging Clause of Article 48(7) TEU. European Constitutional Law Review. 12 (2016) No. 3: 499.

2101 BRICKER, Benjamin. Party Polarization and its Consequences for Judicial Power and Judicial Independence. European Journal of Legal Studies. 10 (2017) No. 1: $161 \mathrm{pp}$.

2102 BROUARDM Sylvain; Hönnige, Christoph. Constitutional Courts as Veto Players: Lessons from the United States, France and Germany. European Journal of Political Research. 56 (2017) No. 3: 529.

2103 BYCZYK, Marcin. A Breach of the Norms of Cautiousness as Fundament for Criminal Responsibility. European Journal of Comparative Law and Governance. 4 (2017) No. 3: 211 pp.

2104 CASTIÑERA JEREZ, Jorge. The Unexpected Change of Circumstances Under American and Spanish Contract Law: Different Concepts, Different Methodology, Similar Outcomes. European Review of Private Law. 25 (2017) No. 5: 909.

2105 CAUFFMAN, Caroline; Smits, Jan. The Sharing Economy and the Law: Food for European Lawyers. Maastricht Journal of European and Comparative Law. 23 (2016) No. 6: 903.

2106 CIVITARESE MATTEUCCI, Stefano. Breaking the Isolation? Italian Perspectives on the Dialogue Between the European Court of Justice and Constitutional Courts. European Public Law. 22 (2016) No. 4: 689. 
2107 CLOOTS, Elke. The Legal Limits of Citizenship Deprivation as a Counterterror Strategy. European Public Law. 23 (2017) No. 1: 57.

2108 COCQ, Céline C. 'Information' and 'Intelligence': The Current Divergences between National Legal Systems and the Need for Common (European) Notions. New Journal of European Criminal Law. 8 (2017) No. 3: 352.

2109 COLOMBO, Carlo; Eliantonio, Mariolina. Harmonized Technical Standards as Part of EU Law: Juridification with a Number of Unresolved Legitimacy Concerns (Case Note). Maastricht Journal of European and Comparative Law. 24 (2017) No. 2: 323.

2110 CONDON, Rónán; van Leeuwen, Barend. Bottom Up or Rock Bottom Harmonization? Francovich State Liability in National Courts. Yearbook of European Law. 35 (2016) No. 1: 229.

2111 COSTA RAMOS, Vânia. The Rights of the Defence According to the ECtHR: An Illustration in the Light of A.T. V. Luxembourg and the Right to Legal Assistance. New Journal of European Criminal Law. 7 (2016) No. 4: 397.

2112 COUTTS, Stephen. Supranational Public Wrongs: The Limitations and Possibilities of European Criminal Law and a European Community. Common Market Law Review. 54 (2017) No. 3: 771.

2113 COVENTRY, Thea. Pretrial Detention: Assessing European Union Competence under Article 82(2) TFEU. New Journal of European Criminal Law. 8 (2017) No. 1: 43.

2114 CROSBY, Scott. Brexit and Brexit Plus: The Non-Material Damage-Thoughts on 29 March 2017. New Journal of European Criminal Law. 8 (2017) No. 2: 99.

2115 CROSBY, Scott. The New Disorder. New Journal of European Criminal Law. 7 (2016) No. 4: 385.

2116 CAPETA, Tamara. Brexit and the EU Constitutional Order: A Three Act Tragedy. Croatian Yearbook of European Law and Policy. 12 (2016): 1.

2117 DA SILVA, Virgilio Afonso. Do We Deliberate? If So, How? European Journal of Legal Studies. 9 (2017) No. 2: 209 pp.

2118 DANI, Marco. National Constitutional Courts in Supranational Litigation: A Contextual Analysis. European Law Journal. 23 (2017) No. 3-4: 189.

2119 DE GRAAFF, Ruben. Concurrent Claims in Contract and Tort: A Comparative Perspective. European Review of Private Law. 25 (2017) No. 4: 701.

2120 DE HERT, Paul; Muraskiewicz, Julia. EU Criminal Law and the Republican Need to Harden Principles into Rules. New Journal of European Criminal Law. 8 (2017) No. 3: 277.

2121 DE LUCIA, Luca. The Rationale of Economics and Law in the Aftermath of the Crisis: A Lesson from Michel Foucault. European Constitutional Law Review. 12 (2016) No. 3: 445.

2122 DE VIDO, Sara. The Ratification of the Council of Europe Istanbul Convention by the EU: A Step Forward in the Protection of Women from Violence in the European Legal System. European Journal of Legal Studies. 9 (2017) No. 2: 69 pp.

2123 DE WITTE, Floris. The Constitutional Quality of the Free Movement Provisions: Looking for Context in the Case Law on Article 56 TFEU. European Law Review. 42 (2017) No. 3: 313.

2124 DEL NEGRO, Guilherme. The Validity of Treaties Concluded under Coercion of the State: Sketching a TWAIL Critique. European Journal of Legal Studies. 10 (2017) No. 1: 39 pp. 
2125 DELFINO, Rossella. European Union Legislation and Actions. European Review of Contract Law. 13 (2017) No. 2: 215.

2126 DENZA, Eileen. The Micro Level: Insights from Specific Policy Areas: Forging Links between Legal Orders. Yearbook of European Law. 35 (2016) No. 1: 589.

2127 DIMITROPOULOS, Georgios. Measuring Judicial Independence in International Law: Putting Together the Pieces of the Puzzle. Maastricht Journal of European and Comparative Law. 24 (2017) No. 4: 531.

2128 DOMURATH, Irina. Mortgage Debt and the Social Function of Contract. European Law Journal. 22 (2016) No. 6: 758.

2129 DOUGAN, Michael. Addressing Issues of Protective Scope within the Francovich Right to Reparation. European Constitutional Law Review. 13 (2017) No. 1: 124.

2130 DÜSTERHAUS, Dominik. The ECtHR, the CJEU and the AFSJ: A Matter of Mutual Trust. European Law Review. 42 (2017) No. 3: 388.

2131 DUTTLE, Thomas [et al.]. Opting out from European Union Legislation: The Differentiation of Secondary Law. Journal of European Public Policy. 24 (2017) No. 3: 406.

2132 DYEVRE, Arthur. Domestic Judicial Defiance in the European Union: A Systemic Threat to the Authority of EU Law? Yearbook of European Law. 35 (2016) No. 1: 106.

2133 ELEFTHERIADIS, Pavlos. Two Doctrines of the Unwritten Constitution. European Constitutional Law Review. 13 (2017) No. 3: 525.

2134 ESPINOSA, Romain; Desrieux, Claudine; Wan, Hengrui. Fewer Courts, Less Justice? Evidence from the 2008 French Reform of Labor Courts. European Journal of Law and Economics. 43 (2017) No. 2: 195.

2135 ESTRADA-TANCK, Dorothy. Undocumented Migrant Women in Europe: A Human Rights Perspective from Public International Law. Croatian Yearbook of European Law and Policy. 12 (2016): 119.

2136 ETTORE PERRIELLO, Luca. Sham Trusts: A Comparative Study. European Review of Private Law. 25 (2017) No. 5: 941.

2137 FABBRINI, Federico; Larik, Joris. The Past, Present and Future of the Relation between the European Court of Justice and the European Court of Human Rights. Yearbook of European Law. 35 (2016) No. 1: 145.

2138 FEIS, Guglielmo. Ought Implies Can: Counter-Examples and Intentions. European Journal of Legal Studies. 9 (2017) No. 2: 37 pp.

2139 FOLLESDAL, Andreas. Independent yet Accountable Stress Test Lessons for the European Court of Human Rights. Maastricht Journal of European and Comparative Law. 24 (2017) No. 4: 484.

2140 FRENZ, Walter. No Judicial Brexit of the German Federal Constitutional Court. European Law Review. 42 (2017) No. 4: 577.

2141 FRERICHS, Sabine. Unravelling the European Community of Debt. European Law Journal. 22 (2016) No. 6: 720.

2142 FROMAGE, Diane. The Second Yellow Card on the EPPO Proposal: An Encouraging Development for Member State Parliaments? Yearbook of European Law. 35 (2016) No. 1: 5 .

2143 GARBEN, Sacha. The Constitutional (Im)balance between 'the Market' and 'the Social' in the European Union. European Constitutional Law Review. 13 (2017) No. $1: 23$. 
2144 GAUCI, Jean-Pierre; Griffith, Arianne; McCorquodale, Robert. Brexit Financial Disputes and Public International Law. European Law Review. 42 (2017) No. 5: 619.

2145 GESSEL-KALINOWSKA VEL KALISZ, Beata. Mixing Legal Systems in Europe; the Role of Common Law Transplants (Polish Law Example). European Review of Private Law. 25 (2017) No. 4: 789.

2146 GIANNOULOPOULOS, Dimitrios. Fair Trial Rights in the UK Post Brexit: Out with the Charter and EU Law, in with the ECHR? New Journal of European Criminal Law. 7 (2016) No. 4: 387.

2147 GRAHAM, Cosmo. Delivering EVEL: English Votes for English Laws. European Public Law. 22 (2016) No. 4: 597.

2148 GRAZIADEI, Stefan. The Strasbourg Court and Challenges to the Constitutional Architecture of Post-Conflict Federalism in Bosnia-Herzegovina and Beyond. Review of Central and East European Law. 42 (2017) No. 2-3: 169.

2149 GRUŠIĆ, Uglješa. International Environmental Litigation in EU Courts: A Regulatory Perspective. Yearbook of European Law. 35 (2016) No. 1: 180.

2150 GRUŠIĆ, Uglješa. Long-Term Business Relationships and Implicit Contracts in European Private Law. European Review of Contract Law. 12 (2016) No. 4: 395.

2151 GUNNARSSON, Eyvindur G. Default Interest Rates in International Transaction: Analyses of Private Law Application. European Review of Private Law. 25 (2017) No. 4: 765.

2152 HACKER, Philipp. Personalizing EU Private Law: From Disclosures to Nudges and Mandates. European Review of Private Law. 25 (2017) No. 3: 651.

2153 HAKET, Sim. The Danish Supreme Court's Ajos judgment (Dansk Industri): Rejecting a Consistent Interpretation and Challenging the Effect of a General Principle of EU Law in the Danish Legal Order. Review of European Administrative Law. 10 (2017) No. 1: 135.

2154 HANSEN, Ole. Public Law by Contract: The Reluctant Creation of Private Markets for Welfare Service. European Review of Private Law. 25 (2017) No. 3: 619.

2155 HARVEY, Darren. Towards Process-Oriented Proportionality Review In The European Union. European Public Law. 23 (2017) No. 1: 93.

2156 HARZL, Benedikt C. Beyond Enlargement: Legal and (Geo-)political Landmarks of the EU's Eastern Challenge. Review of Central and East European Law. 42 (2017) No. 4: 409.

2157 HEFEKER, Carsten; Neugart, Michael. Policy Deviations, Uncertainty, and the European Court of Justice. European Journal of Law and Economics. 42 (2016) No. 3: 547.

2158 HEIDBREDER, Eva G. Strategies in Multilevel Policy Implementation: Moving Beyond the Limited Focus on Compliance. Journal of European Public Policy. 24 (2017) No. 9: 1367.

2159 HERLIN-KARNELL, E. The Challenges of EU Enforcement and Elements of Criminal Law Theory: On Sanctions and Value in Contemporary 'Freedom, Security and Justice' Law. Yearbook of European Law. 35 (2016) No. 1: 291.

2160 HESSELINK, Martijn W. Unjust Conduct in the Internal Market: On the Role of European Private Law in the Division of Moral Responsibility between the EU, Its Member States and Their Citizens. Yearbook of European Law. 35 (2016) No. 1: 410 .

2161 HILDEBRANDT, Achim; Trüdinger, Eva-Maria; Jäckle, Sebastian. Sooner or Later: The Influence of Public Opinion and Religiosity on the Enactment of Laws 
Recognizing Same-Sex Unions. Journal of European Public Policy. 24 (2017) No. 8: 1191.

2162 JANSSEN, André. Die Juristische Zeitschrift als Kurator. European Review of Private Law. 25 (2017) No. 2: 295.

2163 JEMIELNIAK, Joanna. Commercial Stakeholders in International Economic Dispute Resolution and the Issue of Adjudicatory Independence. Maastricht Journal of European and Comparative Law. 24 (2017) No. 4:582.

2164 JIMENO-BULNES, Mar. The Use of Intelligence Information in Criminal Procedure

2165 JOÃO COSTA, Miguel. The Emerging EU Extradition Law. Petruhhin and Beyond. New Journal of European Criminal Law. 8 (2017) No. 2: 192.

2166 JUUTILAINEN, Teemu. Law-Based Commodification of Private Debt. European Law Journal. 22 (2016) No. 6: 743.

2167 KARLIUK, Maksim. The Eurasian Economic Union: An EU-Inspired Legal Order and Its Limits. Review of Central and East European Law. 42 (2017) No. 1: 50.

2168 KELEMEN, Katalin. The New Hungarian Constitution: Legal Critiques from Europe. Review of Central and East European Law. 42 (2017) No. 1: 1.

2169 KEMBAYEV, Zhenis. Recent Constitutional Reforms in Kazakhstan: A Move towards Democratic Transition? Review of Central and East European Law. 42 (2017) No. 4: 294.

2170 KIEBER, Stefan; Klaushofer, Reinhard. The Austrian Constitutional Court Post Case-Law After the Landmark Decision on Charter of Fundamental Rights of the European Union. European Public Law. 23 (2017) No. 2: 221.

2171 KIRKHAM, Richard. Navigating the Storm: Brexit and Judicial Power. European Law Reporter. (2016) No. 5: 191.

$2172 \mathrm{KOCH}$ MIKALSEN, Kjartan. Equal Sovereignty: On the Conditions of Global Political Justice. Arena Working Papers. (2017) No. 9: 27 pp.

2173 KONSTADINIDES, Theodore. The Meso Level: Means of Interaction between EU and International Law: Customary International Law as a Source of EU Law: A Two-Way Fertilization Route? Yearbook of European Law. 35 (2016) No. 1: 513.

2174 KORENICA, Fisnik; Doli, Dren. The CJEU Likes to Blame Loudly and to Applaud Quietly: The Co-Respondent Mechanism in the Light of Opinion 2/13. Maastricht Journal of European and Comparative Law. 24 (2017) No. 1: 86.

2175 KORENICA, Fisnik; Zhubi, Argjend; Doli, Dren. The EU Engineered Hybrid and International Specialist Court in Kosovo: How 'Special' is it? European Constitutional Law Review. 12 (2016) No. 3: 474.

2176 KOSAŘ, David. Politics of Judicial Independence and Judicial Accountability in Czechia: Bargaining in the Shadow of the Law between Court Presidents and the Ministry of Justice. European Constitutional Law Review. 13 (2017) No. 1: 96.

2177 KOUTRAKOS, Panos. A Realist Court? European Law Review. 42 (2017) No. 3: 311.

2178 KOVAC̆, Polonca. Between Theoretical Principles and Practice in Slovene Regulatory Impact Assessment Procedures. Review of Central and East European Law. 42 (2017) No. 2-3: 215.

2179 KROMMENDIJK, Jasper. 'Open Sesame!': Improving Access to the ECJ by Requiring National Courts to Reason their Refusals to Refer. European Law Review. 42 (2017) No. 1: 46.

2180 KÜÇÜK, Esin. Solidarity in EU Law: An Elusive Political Statement or a Legal Principle with Substance? Maastricht Journal of European and Comparative Law. 23 (2016) No. 6: 965. 
2181 KÜNNECKE, Martina. English as Common Legal Language: Its Expansion and the Effects on Civil Law and Common Law Lawyers. European Review of Private Law. 24 (2016) No. 5: 733.

2182 LAMBERUGTS, Stijn. The Privilege against Self-Incrimination: A Chameleon of Criminal Procedure. New Journal of European Criminal Law. 7 (2016) No. 4: 418.

2183 LAVIE, Shay. Discretionary Review and Undesired Cases. European Journal of Law and Economics. 44 (2017) No. 2: 265.

2184 LAW, Stephanie. At the Crossroads of Consumer Protection, Data Protection and Private International Law: Some Remarks on Verein fur Konsumenteninformation v Amazon EU. European Law Review. 42 (2017) No. 5: 751.

2185 LEAL-ARCAS, Rafael; Minas, Stephen. The Micro Level: Insights from Specific Policy Areas: Mapping the International and European Governance of Renewable Energy. Yearbook of European Law. 35 (2016) No. 1: 621.

2186 LEHMANN, Matthias; Ungerer, Johannes. Save the 'Mittelstand': How German Courts Protect Small and Medium-Sized Enterprises from Unfair Terms. European Review of Private Law. 25 (2017) No. 2: 313.

2187 LENAERTS, Koen. La Vie Après L'avis: Exploring the Principle of Mutual (Yet Not Blind) Trust. Common Market Law Review. 54 (2017) No. 3: 805.

2188 LENAERTS, Koen. The European Court of Justice and the Comparative Law Method. European Review of Private Law. 25 (2017) No. 2: 297.

2189 LIND, Anna-Sara. A Living Constitution in Times of Emergency? Sweden. European Public Law. 23 (2017) No. 1: 27.

2190 LOCK, Tobias.The Influence of EU Law on Strasbourg Doctrines. European Law Review. 41 (2016) No. 6: 804.

2191 LÓPEZ GUERRA, Luis. The National Judge and Judicial Independence: The Case of the Strasbourg Court. Maastricht Journal of European and Comparative Law. 24 (2017) No. 4: 552.

2192 LOTH, Marc. Who Has the Last Word? European Review of Private Law. 25 (2017) No. 1: 45 .

2193 MACIEJEWSKI, Tim; Theilen, Jens. Temporal Aspects of the Interaction between National Law and EU Law: Reintroducing the Protection of Legitimate Expectations. European Law Review. 42 (2017) No. 5: 706.

2194 MADSEN, Mikael Rask; Olsen, Henrik Palmer; Šadl, Urška. Competing Supremacies and Clashing Institutional Rationalities: The Danish Supreme Court's Decision in the Ajos Case and the National Limits of Judicial Cooperation. European Law Journal. 23 (2017) No. 1-2: 140.

2195 MAŁECKA, Magdalena. Posner Versus Kelsen: The Challenges for Scientific Analysis of Law. European Journal of Law and Economics. 43 (2017) No. 3: 495.

2196 MANCANO, Leandro. The Place for Prisoners in European Union Law? European Public Law. 22 (2016) No. 4: 717.

2197 MANCANO, Leandro. The Right to Liberty in European Union Law and Mutual Recognition in Criminal Matters. Cambridge Yearbook of European Legal Studies. 18 (2016): 215.

2198 MANES, Vittorio. 'Common Law-ization of Criminal Law'? The Evolution of Nullum Crimen Sine Lege and the Forthcoming Challenges. New Journal of European Criminal Law. 8 (2017) No. 3: 334.

2199 MAREŞ, Mihai. On the Saga Surrounding the Romanian Government Emergency Ordinance No. 13/2017. New Journal of European Criminal Law. 8 (2017) No. 2: 139. 
2200 MARGUERY, Tony. Je t'aime Moi Non Plus: The Avotinš̌ v. Latvia Judgment: An Answer from the ECrtHR to the CJEU. Review of European Administrative Law. 10 (2017) No. 1: 113.

2201 MARLETTA, Angelo. A New Course for Mutual Trust in the AFSJ? Transnational Ne Bis In Idem and the Determination of the Merits of the Case in Kossowski. New Journal of European Criminal Law. 8 (2017) No. 2: 108.

2202 MARTINICO, Giuseppe. Constitutionalism, Resistance, and Openness: Comparative Law Reflections on Constitutionalism in Postnational Governance. Yearbook of European Law. 35 (2016) No. 1: 318.

2203 MASTENBROEK, Ellen. Guardians of EU Law? Analysing Roles and Behaviour of Dutch Legislative Drafters Involved in EU Compliance. Journal of European Public Policy. 24 (2017) No. 9: 1289.

2204 MASTOR, Wanda. The French Intelligence Act: 'The French Surveillance State?'. European Public Law. 23 (2017) No. 4: 707.

2205 MAXWELL, Douglas. Disputed Property Rights: Article 1 Protocol No.1 of the European Convention on Human Rights and the Land Reform (Scotland) Act 2016. European Law Review. 41 (2016) No. 6: 900.

2206 MAYORAL, Juan A. In the CJEU Judges Trust: A New Approach in the Judicial Construction of Europe. Journal of Common Market Studies. 55 (2017) No. 3: 551.

2207 MCCORMACK, Gerard. Corporate Restructuring Law - a Second Chance for Europe? European Law Review. 42 (2017) No. 4: 532.

2208 MELCARNE, Alessandro. Careerism and Judicial Behavior. European Journal of Law and Economics. 44 (2017) No. 2: 241.

2209 MENÉNDEZ, Agustín José. The Guardianship of European Constitutionality. Arena Working Papers. (2017) No. 2: 36 pp.

2210 MICKONYTE், Aistè. The Right to a Name Versus National Identity in the Context of EU Law: The Case of Lithuania. Review of Central and East European Law. 42 (2017) No. 4: 325.

2211 MILONE, Sofia. On the Borders of Criminal Law. A Tentative Assessment of Italian 'Non-Conviction Based Extended Confiscation'. New Journal of European Criminal Law. 8 (2017) No. 2: 150.

2212 MŁYNARSKA-SOBACZEWSKA, Anna. Polish Constitutional Tribunal Crisis: Political Dispute or Falling Kelsenian Dogma of Constitutional Review. European Public Law. 23 (2017) No. 3: 489.

2213 MOLS, Violet. Bringing Directives on Procedural Rights of the EU to Police Stations: Practical Training for Criminal Defence Lawyers. New Journal of European Criminal Law. 8 (2017) No. 3: 300.

2214 MOREIRO GONZÁLEZ, Carlos Javier. The Convergence of Recent International Investment Awards and Case Law on the Principle of Legitimate Expectations: Towards Common Criteria Regarding Fair and Equitable Treatment? European Law Review. 42 (2017) No. 3: 402.

2215 MORENO-LAX, Violeta; Gragl, Paul. Introduction: Beyond Monism, Dualism, Pluralism: The Quest for a (Fully-Fledged) Theoretical Framework: CoImplication, Embeddedness, and Interdependency between Public International Law and EU Law. Yearbook of European Law. 35 (2016) No. 1: 455.

2216 MOTZFELDT, Hanne Marie. The Danish Principle of Administrative Law by Design. European Public Law. 23 (2017) No. 4: 739.

2217 NAVOT, Suzie; Kandelshtein-Haine, Moran. Israel Judicial Enforcement of Ethical Norms in Politics: From the Dismissal of Cabinet Members to the Expulsion of Elected Mayors. European Public Law. 23 (2017) No. 1: 15. 
2218 NIBLETT, Anthony. On the Efficiency of the Common Law: An Application to the Recovery of Rewards. European Journal of Law and Economics. 43 (2017) No. 3: 393.

2219 NIBLOCK, RebeccaM Oehmichen, Anna. Local Law Repercussions on EU Extradition Law: Perspectives from Continental Europe and England and Wales. New Journal of European Criminal Law. 8 (2017) No. 2: 116.

2220 NOVOKMET, Ante. The European Public Prosecutor's Office and the Judicial Review of Criminal Prosecution. New Journal of European Criminal Law. 8 (2017) No. 3: 374.

2221 OLIVEIRA, Álvaro; King, Sarah-Jane. A Good Chess Opening: Luxembourg's First Roma Case Consolidates its Role as a Fundamental Rights Court. European Law Review. 41 (2016) No. 6: 865.

2222 OSTENDORF, Patrick. The Withdrawal Cannot be Withdrawn: The Irrevocability of a Withdrawal Notification under art. 50(2) TEU. European Law Review. 42 (2017) No. 5: 767.

2223 OUWERKERK, Jannemieke W. Criminalization Powers of the European Union and the Risks of Cherry-Picking between Various Legal Bases: The Case for a Single Legal Framework for EU-Level Criminalization. Columbia Journal of European Law. 23 (2017) No. 3: 503.

2224 PACINI, Fabio. The Italian 'Legislation-Cutting' Tool. European Journal of Law Reform. 18 (2016) No. 3: 264.

2225 PAUL, Simon. Governing from the Margins: The European Court of Human Rights' Margin of Appreciation Doctrine as a Tool of Global Governance. Croatian Yearbook of European Law and Policy. 12 (2016): 81.

2226 PERSSON, Anders. Shaping Discourse and Setting Examples: Normative Power Europe can Work in the Israeli-Palestinian Conflict. Journal of Common Market Studies. 55 (2017) No. 6: 1415.

2227 PETTIGREW, Mark. A Vinter Retreat in Europe: Returning to the Issue of Whole Life Sentences in Strasbourg. New Journal of European Criminal Law. 8 (2017) No. 2: 128 .

2228 PILICH, Mateusz. Brexit and EU Private International Law - May the UK Stay in? Maastricht Journal of European and Comparative Law. 24 (2017) No. 3: 382.

2229 POILLOT, Elise. Comparing Legal Clinics: Is There a Way to a European Clinical Culture. European Journal of Comparative Law and Governance. 4 (2017) No. 2: 111 pp.

2230 PREK, Miro; Lefèvre, Silvère. The EU Courts as 'National' Courts: National Law in the EU Judicial Process. Common Market Law Review. 54 (2017) No. 2: 369.

2231 RADEMACHER, Timo. Reading Up or Down EU Legislation: A Plea for a Principled Approach to an Extraordinary Judicial Power. European Public Law. 23 (2017) No. 2: 319 .

2232 RASMUSSEN, Morten. How to Enforce European Law? A New History of the Battle Over the Direct Effect of Directives, 1958-1987. European Law Journal. 23 (2017) No. 3-4: 290.

2233 ROBINSON, William. Managing the EU Acquis. European Journal of Law Reform. 18 (2016) No. 3: 296.

2234 ROKITA, Krzystof. Exclusionary Rebates: Where are we After Post Danmark II and How Did we Get There? European Law Review. 41 (2016) No. 6: 885.

2235 ROSANÒ, Alessandro. Principle of Lex Mitior, Is That you? - Case Note on C-218/15, Paoletti and Others. New Journal of European Criminal Law. 8 (2017) No. 1: 6 . 
2236 RÜHL, Giesela. Who's Afraid of Comparative Law? The (Side) Effects of Unification of Private International Law in Europe. European Review of Private Law. 25 (2017) No. 3: 485 .

2237 RUSSELL, Jago; Hollander, Nancy. The Disappearing Trial: The Global Spread of Incentives to Encourage Suspects to Waive their Right to a Trial and Plead Guilty. New Journal of European Criminal Law. 8 (2017) No. 3: 309.

2238 SANCHO VILLA, Diana. The Concept of Establishment and Data Protection Law: Rethinking Establishment. European Law Review. 42 (2017) No. 4: 491.

2239 SARI, Aurel. Reversing a Withdrawal Notification under Article 50 TEU: Can a Member State Change its Mind? European Law Review. 42 (2017) No. 4: 451.

2240 SCHOLTEN, Miroslava. Mind the Trend! Enforcement of EU Law has been Moving to 'Brussels'. Journal of European Public Policy. 24 (2017) No. 9: 1348.

2241 SCHÜTZE, Robert. Of Types and Tests: Towards a Unitary Doctrinal Framework for Article 34 TFEU? European Law Review. 41 (2016) No. 6: 826.

2242 SCHÜTZE, Robert. Tax Barriers to Intra-Union Trade: American 'Federalism', European 'Internationalism'? Yearbook of European Law. 35 (2016) No. 1: 382.

2243 SCOTT, Paul F. Authority to Carry in the United Kingdom: The Right to Travel, the Privatization of Security and the Rule of Law. European Public Law. 23 (2017) No. 4: 787 .

2244 SHUIBHNE, Niamh Nic. 'What I Tell You Three Times is True': Lawful Residence and Equal Treatment after Dano. Maastricht Journal of European and Comparative Law. 23 (2016) No. 6: 908.

2245 SJURSEJ, Helene. Global Justice and Foreign Policy. Arena Working Papers. (2017) No. 6: 28 pp.

2246 SMITS, Jan; Calomme, Caroline. The Reform of the French Law of Obligations: Les Jeux Sont Faits. Maastricht Journal of European and Comparative Law. 23 (2016) No. 6: 1040.

2247 SNELL, Jukka. Is Opinion 2/13 Obsolescent? European Law Review. 42 (2017) No. 4: 449.

2248 SOLETO MUÑOZ, Helena. The Trial of the 11 March 2004 Madrid Terrorist Attacks. New Journal of European Criminal Law. 8 (2017) No. 2: 216.

2249 SÖLTER, Nicolas. The Abyss of Complexity: Some Remarks on European and German Law in the Migration Crisis. European Public Law. 23 (2017) No. 1: 41.

2250 SOO, Anneli. How are the Member States Progressing on Transposition of Directive 2013/48/EU on the Right of Access to a Lawyer? An Inquiry Conducted among the Member States with the Special Focus on How Article 12 is Transposed. New Journal of European Criminal Law. 8 (2017) No. 1: 64.

2251 SOURESH, Anogika. Jurisdictional Immunities of the State: Why the ICJ Got It Wrong. European Journal of Legal Studies. 9 (2017) No. 2: 15 pp.

2252 SPANO, Robert. The EFTA Court and Fundamental Rights. European Constitutional Law Review. 13 (2017) No. 3: 475.

2253 STEFANOU, Constantin. Comparative Legislative Drafting Comparing across Legal Systems. European Journal of Law Reform. 18 (2016) No. 2: 123.

2254 STEINBACH, Armin. All's Well That Ends Well: Crisis Policy after the German Constitutional Court's Ruling in Gauweiler (Case Note). Maastricht Journal of European and Comparative Law. 24 (2017) No. 1: 140.

2255 STEINBACH, Armin. Effect-Based Analysis in the Court's Jurisprudence on the Euro Crisis. European Law Review. 42 (2017) No. 2: 254. 
2256 STORME, Matthias E. Coping with Diversity and EU Private Law. European Review of Private Law. 25 (2017) No. 3: 483.

2257 STORME, Matthias E. Testing the Central Role of Contract Law. European Review of Private Law. 25 (2017) No. 5: 857.

2258 SYMEONIDOU-KASTANIDOU, Elisavet. Directive 2011/36/EU on Combating Trafficking in Human Beings: Fundamental Choices and Problems of Implementation. New Journal of European Criminal Law. 7 (2016) No. 4: 465.

2259 TAHIRI, Xhafer. 'Judicial Activism' or Constitutional Interpretation?: An Analysis of the Workings of the Constitutional Court of Kosovo. European Public Law. 23 (2017) No. 1: 147.

2260 THEIL, Stefan. Is the 'Living Instrument' Approach of the European Court of Human Rights Compatible with the ECHR and International Law? European Public Law. 23 (2017) No. 3: 587.

2261 THOMANN, Eva; Sager, Fritz. Toward a Better Understanding of Implementation Performance in the EU Multilevel System. Journal of European Public Policy. 24 (2017) No. 9: 1385 .

2262 TOMUSCHAT, Christian. The Micro Level: Insights from Specific Policy Areas: The Relationship between EU Law and International Law in the Field of Human Rights. Yearbook of European Law. 35 (2016) No. 1: 604.

2263 TOPLAK, Jurij; Gardasevic, Djordje. Concepts of National and Constitutional Identity in Croatian Constitutional Law. Review of Central and East European Law. 42 (2017) No. 4: 263.

2264 TORRES PÉREZ, Aida. From Judicial Independence to Interdependence in the International Sphere. Maastricht Journal of European and Comparative Law. 24 (2017) No. 4: 462.

2265 TORRES PÉREZ, Aida. The Independence of the International Judiciary Concept, Methods, and Current Challenges. Maastricht Journal of European and Comparative Law. 24 (2017) No. 4: 459.

2266 TSEBELIS, George. The Time Inconsistency of Long Constitutions: Evidence from the World. European Journal of Political Research. 56 (2017) No. 4: 820.

2267 TUSHNET, Mark. The Boundaries of Comparative Law. European Constitutional Law Review. 13 (2017) No. 1: 13.

2268 VAN BALLEGOOIJ, Wouter; Bárd, Petra. Mutual Recognition and Individual Rights: Did the Court Get it Right? New Journal of European Criminal Law. 7 (2016) No. 4: 439

2269 VAN DEN BERGE, Lukas. Montesquieu and Judicial Review of Proportionality in Administrative Law: Rethinking the Separation of Powers in the Neoliberal Era. European Journal of Legal Studies. 10 (2017) No. 1: 203 pp.

2270 VAN DEN BRINK, Jacobine. The Model Rules on EU Administrative Procedures: Adjudication. Review of European Administrative Law. 10 (2017) No. 1: 155.

2271 VAN DER LOO, Guillaume; Wessel, Ramses A. The Non-Ratification of Mixed Agreements: Legal Consequences and Solutions. Common Market Law Review. 54 (2017) No. 3: 735.

2272 VAN ERP, Sjef. Succession, Registration and the Extraterritorial Application of the Lex Rei State [Editorial]. European Journal of Comparative Law and Governance. 3 (2016) No. 4: 349 pp.

2273 VAN LEEUWEN, Barend. Rethinking the Structure of Free Movement Law: The Centralisation of Proportionality in the Internal Market. European Journal of Legal Studies. 10 (2017) No. 1: 235 pp. 
2274 VAN WOLFEREN, Matthijs. The Limits to the CJEU's Interpretation of Locus Standi, a Theoretical Framework. Journal of Contemporary European Research. 12 (2016) No. 4: 17 pp.

2275 VARGA, Zsófia. In Search of a 'Manifest Infringement of the Applicable Law' in the Terms set out in Köbler. Review of European Administrative Law. 9 (2016) No. 2: 5 .

2276 VARGA, Zsófia. National Remedies in the Case of Violation of EU Law by Member State Courts. Common Market Law Review. 54 (2017) No. 1: 51.

2277 VARGA, Zsófia. Why is the Köbler Principle Not Applied in Practice? Maastricht Journal of European and Comparative Law. 23 (2016) No. 6: 984.

2278 VARJU, Marton. Conflict and Complementarity: EU Obligations, Member State Interests and Services of General Interest. European Public Law. 23 (2017) No. 2: 347.

2279 VÁRNAY, Ernő. Sanctioning Under Article 260 (3) TFEU: Much Ado About Nothing? European Public Law. 23 (2017) No. 2: 301.

2280 VASEV, Nikolay; Vrangbæk; Křepelka, Filip. The End of Eastern Territoriality? CJEU Compliance in the New Member States. Comparative European Politics. 15 (2017) No. 3: 459.

2281 VOIGT, Stefan. The Independence of International Courts: Making Reputation Work? Maastricht Journal of European and Comparative Law. 24 (2017) No. 4: 511.

2282 VOLPATO, Annalisa. The Harmonized Standards Before the ECJ: James Elliott Construction. Common Market Law Review. 54 (2017) No. 2: 591.

2283 WALLERMAN, Anna. Harmonization of Civil Procedure: Can the European Union Learn from Swiss Experiences? European Review of Private Law. 24 (2016) No. 5: 855.

2284 WERNER, Benjamin. National Responses to the European Court of Justice Case Law on Golden Shares: The Role of Protective Equivalents. Journal of European Public Policy. 24 (2017) No. 7: 989.

2285 WESSEL, Ramses A. The Meso Level: Means of Interaction between EU and International Law: Flipping the Question: The Reception of EU Law in the International Legal Order. Yearbook of European Law. 35 (2016) No. 1: 533.

2286 WEYEMBERG, Anne. Consequences of Brexit for European Union Criminal Law. New Journal of European Criminal Law. 8 (2017) No. 3: 284.

2287 WHELANOVÁ, Markéta. Quo Vadis, Europa? Loopholes in the EU Law and Difficulties in the Implementation Process. European Journal of Law Reform. 18 (2016) No. 2: 179 .

2288 WILKINSON, Michael A. Constitutional Pluralism: Chronicle of a Death Foretold? European Law Journal. 23 (2017) No. 3-4: 213.

2289 WOLLENSHCLÄGER, Ferdinand.ConstitutionalisationandDeconstitutionalisation of Administrative Law in View of Europeanisation and Emancipation. Review of European Administrative Law. 10 (2017) No. 1: 7.

2290 WRIGHT, Susan. The French Conseil constitutionnel under an Evolving Constitution. European Public Law. 23 (2017) No. 2: 245.

2291 YOUNG, Alison L. (Miller) v Secretary of State for Exiting the European Union: Thriller or Vanilla? European Law Review. 42 (2017) No. 2: 280.

2292 YOUNG, Alison L. The Constitutional Implications of Brexit. European Public Law. 23 (2017) No. 4: 757. 
2293 ZBÍRAL, Robert. Comparing the Intensity of Scrutiny for 'Domestic' and Implementing Bills: Does Transposition of EU Law Reduce Political Contestation in National Parliaments? Journal of European Public Policy. 24 (2017) No. 7: 969.

2294 ZHU, Guangxing; van der Aa, Suzan. Trends of Age of Consent Legislation in Europe: A Comparative Study of 59 Jurisdictions on the European Continent. New Journal of European Criminal Law. 8 (2017) No. 1: 14.

2295 ZIEGLER, Katja S. Closing Chapter: Piecing the Puzzle Together: Beyond Pluralism and Autonomy: Systemic Harmonization as a Paradigm for the Interaction of EU Law and International Law. Yearbook of European Law. 35 (2016) No. 1: 667. 